\title{
Aspects of postprandial protein handling
}

Citation for published version (APA):

Groen, B. B. L. (2016). Aspects of postprandial protein handling. [Doctoral Thesis, Maastricht University]. Datawyse / Universitaire Pers Maastricht. https://doi.org/10.26481/dis.20161104bg

Document status and date:

Published: 01/01/2016

DOI:

$10.26481 /$ dis.20161104bg

Document Version:

Publisher's PDF, also known as Version of record

\section{Please check the document version of this publication:}

- A submitted manuscript is the version of the article upon submission and before peer-review. There can be important differences between the submitted version and the official published version of record.

People interested in the research are advised to contact the author for the final version of the publication, or visit the DOI to the publisher's website.

- The final author version and the galley proof are versions of the publication after peer review.

- The final published version features the final layout of the paper including the volume, issue and page numbers.

Link to publication

\footnotetext{
General rights rights.

- You may freely distribute the URL identifying the publication in the public portal. please follow below link for the End User Agreement:

www.umlib.nl/taverne-license

Take down policy

If you believe that this document breaches copyright please contact us at:

repository@maastrichtuniversity.nl

providing details and we will investigate your claim.
}

Copyright and moral rights for the publications made accessible in the public portal are retained by the authors and/or other copyright owners and it is a condition of accessing publications that users recognise and abide by the legal requirements associated with these

- Users may download and print one copy of any publication from the public portal for the purpose of private study or research.

- You may not further distribute the material or use it for any profit-making activity or commercial gain

If the publication is distributed under the terms of Article $25 \mathrm{fa}$ of the Dutch Copyright Act, indicated by the "Taverne" license above, 
Aspects of
Postprandial
protein handling

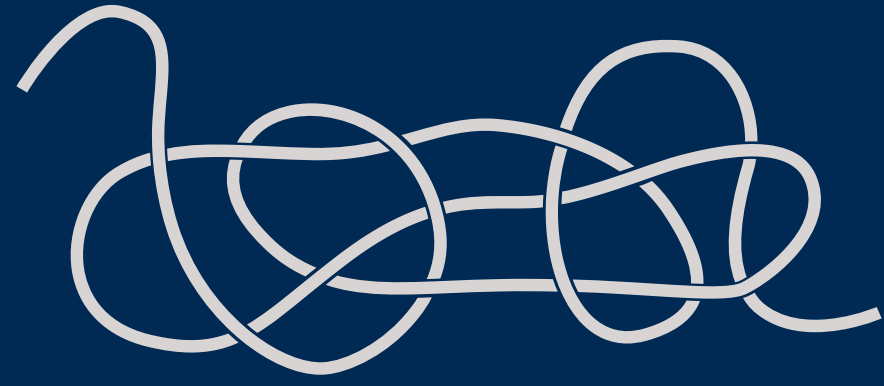

Bart Groen 
Financial support:

Huisartsenopleiding Nederland

Maastricht University

Maastricht University

Nutricia Research

$\stackrel{0}{\circ}$ NUTRIM

Rogier Trompert Medical Art

\author{
Rogier Trompert Medical Art \\ medische en wetenschappelijke illustratie
}

C Bart Groen, Maastricht 2016

No part of this book may be reproduced or transmitted in any form or by any means, without prior permission in writing by the author, or when appropriate, by the publishers of the publications.

Layout: Tiny Wouters

Cover design: JJ Groen en BBL Groen

Figure 1.1: Rogier Trompert, Rogier Trompert Medical Art

Production: Datawyse | Universitaire Pers Maastricht

ISBN: 9789461596116 


\title{
Aspects of postprandial protein handling
}

\author{
PROEFSCHRIFT \\ ter verkrijging van de graad van doctor aan de Universiteit Maastricht, \\ op gezag van de Rector Magnificus, Prof. dr. Rianne M. Letschert, \\ volgens het besluit van het College van Decanen, \\ in het openbaar te verdedigen op \\ vrijdag 4 november 2016 om 12.00 uur \\ door
} Bartholomeus Barber Leonard Groen 


\section{Promotor}

Prof. dr. L.J.C. van Loon

\section{Copromotor}

Dr. A.M.H. Horstman

\section{Beoordelingscommissie}

Prof. dr. E.E. Blaak (chair)

Prof. dr. C.P.G.M. de Groot (WUR, Wageningen)

Prof. dr. S.W.M. Olde Damink

Prof. dr. O. Rooijackers (Karolinska Institutet, Sweden)

Prof. dr. J.M.G.A. Schols 


\section{Contents}

$\begin{array}{lll}\text { Chapter } 1 & \text { General introduction } & 7\end{array}$

Chapter $2 \quad$ Postprandial protein handling: you are what you just ate 21

Chapter $3 \quad$ Increasing insulin availability does not augment postprandial $\quad 45$ muscle protein synthesis in healthy young and older men

$\begin{array}{lll}\text { Chapter } 4 & \text { Skeletal muscle capillary density and microvascular function are } \quad 73\end{array}$ compromised with aging and type 2 diabetes

Chapter $5 \quad$ Intragastric protein administration stimulates overnight muscle 91 protein synthesis in elderly men

Chapter $6 \quad$ Neuromuscular electrical stimulation increases postprandial muscle protein accretion during overnight sleep

Chapter $7 \quad$ General discussion

Summary

Samenvatting

Valorisation

Dankwoord 163

Curriculum vitae 167

List of publications 171 



\section{Chapter 1}

General introduction 
Chapter 1 


\section{Introduction}

In almost every country, the proportion of people aged over 60 years is growing faster than any other age group, as a result of both longer life expectancy and declining fertility rates. ${ }^{1}$ Global demographics indicate that the number of individuals aged 60 years and over will triple by the year 2050, with the fastest growing subpopulation being those aged 85 years and older. ${ }^{2}$ As such, the proportion of elderly in the population will increase from $\sim 15 \%$ to more than $25 \%$ within the next 35 years. ${ }^{2,3}$ This population ageing can be seen as a success story for public health policies and socioeconomic development, but it also challenges society to adapt, to maximize the health and functional capacity of older people as well as their social participation and security. The aging of our population will have a major impact on our healthcare system due to increased morbidity and greater need for institutionalization and/or hospitalization. ${ }^{4}$

Good health is essential for older people to remain independent, physically active, and participate in family and community life. Life-long health promotion is warranted to prevent or delay the onset of non-communicable and chronic metabolic diseases, like heart disease, stroke, cancer, and diabetes. ${ }^{5}$ Besides the impact on the health care costs, future perspectives about extension of retirement age will also influence the demands on the aging working population. ${ }^{6}$ From a socio-economic perspective, it is important that the older population maintains a healthy, active lifestyle. The capacity to stay active largely depends on the impact of age on functional capacity. Functional capacity and mobility strongly correlate with muscle strength and muscle power, which in turn are largely determined by the amount of muscle mass available. ${ }^{7}$ Even with healthy aging, a gradual, progressive decline in muscle mass and strength seems inevitable with an advancing age..$^{3,8,9}$ The loss of skeletal muscle mass and function with aging has been termed sarcopenia. ${ }^{8}$ Sarcopenia is viewed as a largely inevitable and undesirable consequence of ageing, ${ }^{10}$ with substantial muscle loss estimated to affect $30 \%$ of those people older than 60 years and $>50 \%$ of those older than 80 years. ${ }^{11}$ Sarcopenia has been recognized as an important factor in determining the inability of elderly people to remain living independently, and has been associated with an increased prevalence of comorbidities ${ }^{12}$ and a reduction in the overall quality of life. ${ }^{13,14}$ Muscle mass maintenance has proven to be challenging for the older population.

\section{Muscle mass maintenance}

Muscle protein accounts for about $50 \%$ of total body protein pool and serves as the principal reservoir of amino acids. ${ }^{15}$ The body's free amino acid pool is small compared with the body's protein-bound amino acid pool, e.g. $200 \mathrm{~g}$ versus $\sim 12,000 \mathrm{~g}$ in a $70-\mathrm{kg}$ adult man, and varies considerably between the successive stages of feeding and 
fasting. ${ }^{16}$ Both amino acid pools are closely related through the process of whole-body protein turnover, which is crucial for maintaining tissue protein quantity and quality. ${ }^{17}$ Skeletal muscle protein is in a constant state of turnover, with muscle protein being continuously synthesized and broken down. ${ }^{18}$ Skeletal muscle protein turns over at a rate of $1-2 \%$ per day. ${ }^{3}$ In a healthy, weight-stable young male with a bodyweight of 70 $\mathrm{kg}$, this would represent 350-700 g muscle tissue being broken down and resynthesized every day, with an entire renewal of the body's skeletal muscle protein pool in $\sim 2-3$ months. ${ }^{19}$

The net loss of muscle mass with aging must be attributed to a structural imbalance between muscle protein synthesis and breakdown rates, resulting in a net negative protein balance. In an attempt to unravel the proposed impairments in muscle protein metabolism in the elderly, many research groups first assessed basal muscle protein synthesis and/or protein breakdown rates in both young and elderly subjects. ${ }^{20-22}$ For a long time, it has been suggested that basal (fasted) muscle protein synthesis rates were lower in the older compared with the young. ${ }^{3,22}$ However, more recent studies have failed to reproduce these findings and generally show little or no differences in basal muscle protein synthesis rates between the young and old. ${ }^{21,23}$ However, it should be noted that the assessment of fractional muscle protein synthetic rate in vivo has its methodological limitations. ${ }^{24,25}$ The sensitivity of the measurements and large intersubject variance in basal muscle protein synthesis rates may limit the ability to detect very small, but physiologically relevant, differences in basal muscle protein synthesis and/or breakdown rates between groups. Even minor differences in basal muscle protein synthesis and/or breakdown rates ( 1-2\%) can become clinically relevant when calculating their impact over one or more decades before sarcopenia becomes evident. $^{3}$

Because of the absence of measurable differences in basal, post-absorptive muscle protein synthesis rates, many research groups have started to focus on the muscle protein synthetic response to the main anabolic stimuli, i.e., food intake ${ }^{16}$ and physical activity. ${ }^{26}$ Muscle mass maintenance is largely regulated by the continuous up and down regulation of muscle protein synthesis and breakdown rates. The response to these main anabolic stimuli, being food intake and physical activity, play a key role in this process. Ingestion of protein, followed by protein digestion and amino acid absorption, results in a rapid postprandial rise in plasma amino acid concentrations. The postprandial rise in circulating (essential) amino acids, with leucine being or particular relevance, increases muscle protein synthesis rates and inhibits proteolysis, leading to net muscle protein accretion. ${ }^{3,27,28}$ The postprandial muscle protein synthetic response to feeding is regulated on various levels (Figure 1.1), ranging from dietary protein digestion and amino acid absorption, ${ }^{29,30}$ the postprandial rise in circulating insulin and subsequent increase in microvascular recruitment, ${ }^{31,32}$ amino acid transport 
to and uptake in skeletal muscle tissue, ${ }^{33}$ intramuscular anabolic signaling,,$^{34,35}$ and finally myofibrillar muscle protein synthesis and breakdown. ${ }^{36}$

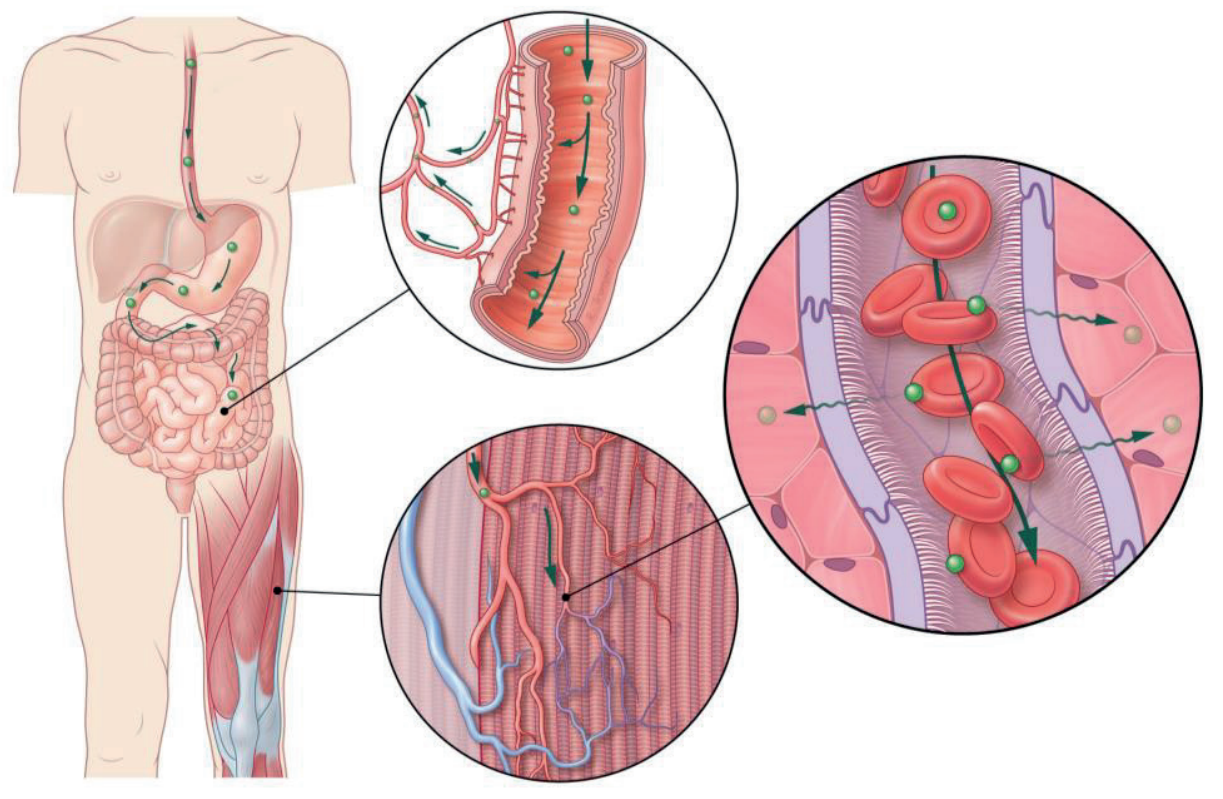

Figure 1.1 Schematic representation of postprandial protein handling.

Recent studies suggest that the muscle protein synthetic response to food intake is blunted in the elderly. ${ }^{37-40}$ The reduced capacity of senescent muscle to increase muscle protein synthesis rates following protein or amino acid administration has been coined anabolic resistance, ${ }^{40}$ and is now believed to represent a key factor responsible for the age-related decline in skeletal muscle mass. Though we know that anabolic resistance to feeding is modulated by health status, habitual physical activity, and/or dietary habits, ${ }^{41}$ the mechanisms responsible for the blunted muscle protein synthetic response to feeding remain unclear. Impairments in postprandial protein handling may reside at the level of dietary protein digestion, ${ }^{42}$ amino acid absorption, ${ }^{43}$ the postprandial hormonal response ${ }^{44}$ and subsequent microvascular perfusion, ${ }^{45,46}$ amino acid uptake in skeletal muscle tissue, ${ }^{47}$ intramuscular signaling, and/or myofibrillar muscle protein accretion. ${ }^{34}$ Impaired dietary protein digestion and subsequent reduced amino acid absorption rates, and/or a greater retention of ingested amino acids within the splanchnic area have been observed in older compared with younger men, ${ }^{43}$ although not all studies confirm this. ${ }^{28}$ Such findings imply that fewer amino acids may become available in the circulation for postprandial muscle protein synthesis. Insulin resistance at the level of capillary recruitment-mediated muscle perfusion following meal 
ingestion seems to be another important factor that may be responsible for the development of the anabolic resistance of feeding. ${ }^{48,49}$ However, dynamic measurements of amino acid transport to skeletal muscle tissue following meal ingestion are necessary to confirm whether this is a potential site of regulation for the etiology of age-related anabolic resistance.

\section{Perfusion of muscle tissue and endothelial function}

Adequate blood perfusion of muscle tissue is essential for maintenance of muscle mass. Perfusion determines the rapid postprandial delivery of oxygen, nutrients, amino acids and growth factors to muscle tissue, thereby stimulating muscle protein synthesis. Both the vascular density in muscle tissue (quantity), as well as the transport capacity over the vessel walls (quality) determine proper (postprandial) perfusion. The human body regulates both the quantity and quality of tissue perfusion in multiple ways. ${ }^{50-52}$ Besides mechanical ways to increase or decrease blood flow, ${ }^{53}$ hormonal regulation of muscle perfusion plays an important role. ${ }^{54,55}$ The postprandial increase in circulating insulin concentration displays a dose-dependent increase in skeletal muscle blood flow via nitric oxide (NO)-dependent vasodilation of the (micro)vasculature and has been identified as a potent stimulus for muscle protein anabolism. ${ }^{56,57}$ In vitro studies have shown that insulin can stimulate muscle protein synthesis by direct activation of the translational machinery. ${ }^{58}$ Insulin may also affect protein metabolism in vivo due to its vasoactive properties. ${ }^{59}$ The postprandial rise in circulating insulin stimulates endothelial-dependent vasodilation by virtue of its action on endothelial nitric oxide synthase, resulting in greater capillary recruitment, increased microvascular volume, and nutritive blood flow to skeletal muscle tissue. ${ }^{60}$ It could be speculated that a more pronounced postprandial rise in circulating insulin will stimulate the perfusion of more insulin sensitive tissues, thereby increasing the exposure to nutrients and growth factors, and increasing protein synthesis. However, whether insulin has a stimulatory effect on postprandial muscle protein synthesis in humans has been the subject of intense debate. ${ }^{61,62}$ Many believe that circulating insulin concentrations are simply permissive, as opposed to modulatory, to allow a postprandial increase in muscle protein synthesis rate in healthy young subjects. ${ }^{61}$ In line, it has been proposed that plasma insulin concentrations of $15-30 \mathrm{uU} / \mathrm{mL}$ are already sufficient to allow maximal postprandial stimulation of muscle protein synthesis rates in vivo in humans. ${ }^{61,63}$ However, it could be speculated that older, more insulin resistant, adults may experience some level of anabolic resistance due to impairments in postprandial amino acid provision to the muscle, as a consequence of vascular dysfunction. ${ }^{31,64,65}$

Vascular dysfunction may be attributed to changes in microvascular structure and endothelial function, which may include an overall decline in capillary density as well as structural changes of the endothelial wall. ${ }^{46,55}$ As aging is associated with the 
development of vascular dysfunction, it has been proposed that impairments in the postprandial responsiveness of skeletal muscle tissue microvasculature may be responsible for the development of anabolic resistance and, as such, the age-related decline in muscle mass and function. ${ }^{31,60,66}$

Besides changes in microvascular structure, there are data to indicate that the endothelial wall function is compromised in senescent tissue. ${ }^{67,68}$ In the search for novel targets to assess microvascular function, the recognition of the potential role of the endothelial glycocalyx layer (Figure 1.2) in mediating vascular function has been introduced and offers new and exciting opportunities. ${ }^{69,70}$

The surface layer of endothelial cells, directly contacting the blood flow, is covered by a fuzzy coat of glycosaminoglycans (long unbranched polysaccharides consisting of a repeating disaccharide unit). ${ }^{71}$ This structure is approximately 500-1000 ångströms thick and represents an extra-endothelial barrier that fluid and solutes must traverse in crossing these cells. ${ }^{72}$ Disruption or enzymatic removal of this layer alters microvascular permeability, indicating that the glycocalyx offers restriction to solute transfer. ${ }^{73}$ Interestingly, this structure is present on venous, arterial and arteriolar endothelial cells ${ }^{50}$ and quickly responds to the presence of insulin by increasing endothelial wall permeability. ${ }^{74}$ Little is known about the role of the endothelial glycocalyx in the regulation of (postprandial) muscle tissue perfusion. As there seems to be a mechanistic link between age related muscle loss and the development of insulin resistance, it could be speculated that muscle tissue perfusion may be impaired by changes in the permeability of the endothelial glycocalyx, thereby blunting the postprandial muscle protein synthetic response to feeding in older, more insulin resistant adults.

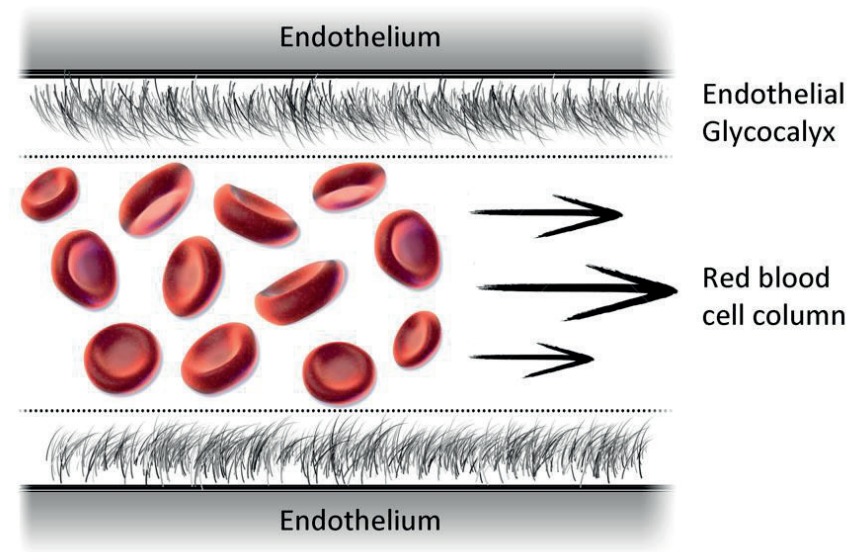

Figure 1.2 The endothelial glycocalyx (schematic representation). 


\section{Physical activity and muscle maintenance}

Besides food intake, physical activity is another main anabolic stimulus. ${ }^{23,75-77}$ A single bout of physical activity stimulates muscle protein synthesis as well as muscle protein breakdown rates, albeit the latter to a lesser extent, thereby improving muscle protein balance. ${ }^{75,76}$ However, muscle protein balance will remain negative in the absence of food intake. ${ }^{75}$ Therefore, food intake is required to allow post-exercise muscle protein balance to become positive, allowing the skeletal muscle adaptive response to physical activity or exercise training to occur. Interestingly, the anabolic properties of food intake and physical activity are synergistic, with physical activity making the muscle more sensitive to the anabolic properties of amino acids. ${ }^{78}$ Physical activity performed prior to food intake will further augment the muscle protein synthetic response to feeding, and allows more of the ingested protein to be used for de novo muscle protein synthesis. ${ }^{30}$ This anabolic response to physical activity plays a key role in the skeletal muscle adaptive response to prolonged endurance or resistance type exercise training and allows our skeletal muscle to adapt to our needs. As habitual physical activity plays a key role in stimulating the muscle protein synthetic response to feeding, it has been proposed that the anabolic resistance of aging is largely attributed to a more sedentary lifestyle. ${ }^{79}$ In agreement, muscle disuse and physical inactivity have been shown to induce anabolic resistance. ${ }^{80-82}$ Clearly, understanding the impact of physical (in)activity and muscle contraction on muscle protein synthesis and the anabolic response to feeding may also elucidate the mechanisms responsible for the development of anabolic resistance.

\section{Outline of the dissertation}

This dissertation describes a series of studies that investigate the various aspects that can modulate postprandial protein handling and the subsequent muscle protein synthetic response to protein ingestion in young and older adults. In chapter $\mathbf{2}$ we combine a number of methods to assess dietary protein digestion and subsequent amino acid absorption, the appearance of dietary protein derived amino acids in the circulation, the uptake and release of amino acids over the leg, the postprandial stimulation of muscle protein synthesis as well as the use of protein derived amino acids for de novo muscle protein synthesis in vivo in humans within one single experiment. Consequently, this chapter quantifies postprandial protein handling and the subsequent use of dietary protein derived amino acids for de novo muscle protein synthesis, showing that we actually are what we eat. In chapter $\mathbf{3}$, we used the same methodology to assess whether the postprandial increase in circulating insulin is required to maximize postprandial amino acid uptake in muscle and, as such, to augment the muscle protein synthetic response in both young and older males. 
Microvascular dysfunction has been suggested as a factor that may be, at least partly, responsible for the development of anabolic resistance. In chapter $\mathbf{4}$, we compare muscle mass, insulin sensitivity, and microvascular structure and function between healthy, young males, healthy older males, and insulin resistant older males. Both quantitative and qualitative differences in the microvasculature are assessed, to see whether changes in endothelial function and insulin sensitivity may explain differences in muscle mass between these groups. To compensate for anabolic resistance to feeding we expanded the window of opportunity for nutritional support by dietary protein provision during the night. In a proof-of-principle study, we first measured dietary protein digestion and absorption kinetics and the subsequent muscle protein synthetic response following dietary protein administration via a nasogastric tube during sleep in older men (chapter 5). In chapter 6, we followed up on this work by the application of neuromuscular electrical stimulation as an exercise mimetic to further augment the overnight muscle protein synthetic response to protein administration prior to sleep. The application of neuromuscular electrical stimulation combined with subsequent protein ingestion may represent an effective interventional strategy to optimize overnight muscle protein accretion, and may proof to be of great clinical relevance to prevent or attenuate the loss of skeletal muscle tissue during periods of bed rest or immobilization in more clinically compromised older individuals. 


\section{References}

1. Beard JR, Officer A, de Carvalho IA, Sadana R, Pot AM, Michel JP, et al. The World report on ageing and health: a policy framework for healthy ageing. Lancet. 2015.

2. WHO. World Population Ageing 2013. Economics \& Social Affairs, 2013.

3. Koopman R, van Loon LJ. Aging, exercise, and muscle protein metabolism. J Appl Physiol. 2009;106:2040-8.

4. Schneider EL, Guralnik JM. The aging of America. Impact on health care costs. JAMA. 1990;263:2335-40.

5. Koopman R. Dietary protein and exercise training in ageing. Proc Nutr Soc. 2011;70:104-13.

6. Angus DC, Kelley MA, Schmitz RJ, White A, Popovich J, Jr., Committee on Manpower for P, et al. Caring for the critically ill patient. Current and projected workforce requirements for care of the critically ill and patients with pulmonary disease: can we meet the requirements of an aging population? JAMA. 2000;284:2762-70.

7. Faulkner JA, Larkin LM, Claflin DR, Brooks SV. Age-related changes in the structure and function of skeletal muscles. Clin Exp Pharmacol Physiol. 2007;34:1091-6.

8. Walrand S, Guillet C, Salles J, Cano N, Boirie Y. Physiopathological mechanism of sarcopenia. Clin Geriatr Med. 2011;27:365-85.

9. Evans W. What is sarcopenia? The Journals of Gerontology Series .... 1995.

10. Paddon-Jones D, Rasmussen BB. Dietary protein recommendations and the prevention of sarcopenia. Curr Opin Clin Nutr Metab Care. 2009;12:86-90.

11. Mitchell WK, Williams J, Atherton P, Larvin M, Lund J, Narici M. Sarcopenia, dynapenia, and the impact of advancing age on human skeletal muscle size and strength; a quantitative review. Front Physiol. 2012;3:260.

12. Sayer AA. Sarcopenia. BMJ. 2010;341:c4097.

13. Janssen I, Heymsfield SB, Ross R. Low relative skeletal muscle mass (sarcopenia) in older persons is associated with functional impairment and physical disability. J Am Geriatr Soc. 2002;50:889-96.

14. Rolland Y, Czerwinski S, Abellan Van Kan G, Morley JE, Cesari M, Onder G, et al. Sarcopenia: its assessment, etiology, pathogenesis, consequences and future perspectives. J Nutr Health Aging. 2008;12:433-50.

15. Felig P. Amino acid metabolism in man. Annu Rev Biochem. 1975;44:933-55.

16. Rennie MJ, Edwards RH, Halliday D, Matthews DE, Wolman SL, Millward DJ. Muscle protein synthesis measured by stable isotope techniques in man: the effects of feeding and fasting. Clin Sci (Lond). 1982;63:519-23.

17. Dorrens J, Rennie MJ. Effects of ageing and human whole body and muscle protein turnover. Scand J Med Sci Sports. 2003;13:26-33.

18. Nair KS. Muscle protein turnover: methodological issues and the effect of aging. J Gerontol A Biol Sci Med Sci. 1995;50 Spec No:107-12.

19. Smith K, Rennie MJ. Protein turnover and amino acid metabolism in human skeletal muscle. Baillieres Clin Endocrinol Metab. 1990;4:461-98.

20. Volpi E, Sheffield-Moore M, Rasmussen BB, Wolfe RR. Basal muscle amino acid kinetics and protein synthesis in healthy young and older men. JAMA. 2001;286:1206-12.

21. Paddon-Jones D, Sheffield-Moore M, Zhang XJ, Volpi E, Wolf SE, Aarsland A, et al. Amino acid ingestion improves muscle protein synthesis in the young and elderly. Am J Physiol Endocrinol Metab. 2004;286:E321-8.

22. Koopman R, Verdijk L, Manders RJ, Gijsen AP, Gorselink M, Pijpers E, et al. Co-ingestion of protein and leucine stimulates muscle protein synthesis rates to the same extent in young and elderly lean men. Am J Clin Nutr. 2006;84:623-32.

23. Kumar V, Selby A, Rankin D, Patel R, Atherton P, Hildebrandt W, et al. Age-related differences in the dose-response relationship of muscle protein synthesis to resistance exercise in young and old men. J Physiol. 2009;587:211-7.

24. Rennie MJ, Smith K, Watt PW. Measurement of human tissue protein synthesis: an optimal approach. Am J Physiol. 1994;266:E298-307. 
25. Rennie MJ, Selby A, Atherton P, Smith K, Kumar V, Glover EL, et al. Facts, noise and wishful thinking: muscle protein turnover in aging and human disuse atrophy. Scand J Med Sci Sports. 2010;20:5-9.

26. Evans WJ. Effects of exercise on body composition and functional capacity of the elderly. J Gerontol A Biol Sci Med Sci. 1995;50 Spec No:147-50.

27. Beelen M, Koopman R, Gijsen AP, Vandereyt H, Kies AK, Kuipers H, et al. Protein coingestion stimulates muscle protein synthesis during resistance-type exercise. Am J Physiol Endocrinol Metab. 2008;295: E70-7.

28. Koopman R, Walrand S, Beelen M, Gijsen AP, Kies AK, Boirie Y, et al. Dietary protein digestion and absorption rates and the subsequent postprandial muscle protein synthetic response do not differ between young and elderly men. J Nutr. 2009;139:1707-13.

29. Rodriguez P, Setten M, Maskin L, Bonelli I, Vidomlansky S, Attie S, et al. Muscle weakness in septic patients requiring mechanical ventilation: protective effect of transcutaneous neuromuscular electrical stimulation. J Crit Care. 2012;27:3190-8.

30. Pennings B, Koopman R, Beelen M, Senden JM, Saris WH, van Loon LJ. Exercising before protein intake allows for greater use of dietary protein-derived amino acids for de novo muscle protein synthesis in both young and elderly men. Am J Clin Nutr. 2011;93:322-31.

31. Rasmussen BB, Fujita S, Wolfe RR, Mittendorfer B, Roy M, Rowe VL, et al. Insulin resistance of muscle protein metabolism in aging. FASEB J. 2006;20:768-9.

32. Zhang H, Dellsperger K, Zhang $C$. The link between metabolic abnormalities and endothelial dysfunction in type 2 diabetes: an update. Basic Res Cardiol. 2012;107:237.

33. English K, Paddon-Jones D. Protecting muscle mass and function in older adults during bed rest. Curr Opin Clin Nutr Metab Care. 2010;13:34-9.

34. Cuthbertson D, Smith K, Babraj J, Leese G, Waddell T, Atherton P, et al. Anabolic signaling deficits underlie amino acid resistance of wasting, aging muscle. FASEB J. 2005;19:422-4.

35. Fry CS, Drummond MJ, Glynn EL, Dickinson JM, Gundermann DM, Timmerman KL, et al. Aging impairs contraction-induced human skeletal muscle mTORC1 signaling and protein synthesis. Skelet Muscle. 2011;1:11.

36. Volpi E, Ferrando A, Yeckel C, Tipton K, Wolfe R. Exogenous amino acids stimulate net muscle protein synthesis in the elderly. J Clin Invest. 1998;101:2000-7.

37. Rennie MJ, Wilkes EA. Maintenance of the musculoskeletal mass by control of protein turnover: the concept of anabolic resistance and its relevance to the transplant recipient. Ann Transplant. 2005;10:31-4.

38. Breen L, Phillips SM. Skeletal muscle protein metabolism in the elderly: Interventions to counteract the 'anabolic resistance' of ageing. Nutr Metab (Lond). 2011;8:68.

39. Burd NA, Gorissen SH, van Loon LJ. Anabolic resistance of muscle protein synthesis with aging. Exerc Sport Sci Rev. 2013;41:169-73.

40. Burd NA, Wall BT, van Loon LJ. The curious case of anabolic resistance: old wives' tales or new fables? J Appl Physiol. 2012;112:1233-5.

41. Fiatarone MA, O'Neill EF, Ryan ND, Clements KM, Solares GR, Nelson ME, et al. Exercise training and nutritional supplementation for physical frailty in very elderly people. N Engl J Med. 1994;330:1769-75.

42. Dangin M, Guillet C, Garcia-Rodenas C, Gachon P, Bouteloup-Demange C, Reiffers-Magnani K, et al. The rate of protein digestion affects protein gain differently during aging in humans. J Physiol. 2003;549: 635-44.

43. Fujita S, Volpi E. Amino acids and muscle loss with aging. J Nutr. 2006;136:277S-80S.

44. Attaix D, Mosoni L, Dardevet D, Combaret L, Mirand PP, Grizard J. Altered responses in skeletal muscle protein turnover during aging in anabolic and catabolic periods. Int J Biochem Cell Biol. 2005;37: 1962-73.

45. Timmerman K, Lee J, Fujita S, Dhanani S, Dreyer H, Fry C, et al. Pharmacological vasodilation improves insulin-stimulated muscle protein anabolism but not glucose utilization in older adults. Diabetes. 2010;59:2764-71.

46. Timmerman KL, Lee JL, Dreyer HC, Dhanani S, Glynn EL, Fry CS, et al. Insulin stimulates human skeletal muscle protein synthesis via an indirect mechanism involving endothelial-dependent vasodilation and mammalian target of rapamycin complex 1 signaling. J Clin Endocrinol Metab. 2010;95:3848-57. 
47. Drummond M, Glynn E, Fry C, Timmerman K, Volpi E, Rasmussen B. An increase in essential amino acid availability upregulates amino acid transporter expression in human skeletal muscle. Am J Physiol Endocrinol Metab. 2010;298:8.

48. Muller-Delp JM, Spier SA, Ramsey MW, Delp MD. Aging impairs endothelium-dependent vasodilation in rat skeletal muscle arterioles. Am J Physiol Heart Circ Physiol. 2002;283:H1662-72.

49. Clark MG, Wallis MG, Barrett EJ, Vincent MA, Richards SM, Clerk LH, et al. Blood flow and muscle metabolism: a focus on insulin action. Am J Physiol Endocrinol Metab. 2003;284:E241-58.

50. Korthuis RJ. Skeletal Muscle Circulation. Integrated Systems Physiology: from Molecule to Function to Disease. San Rafael (CA)2011.

51. Delp MD, Laughlin MH. Regulation of skeletal muscle perfusion during exercise. Acta Physiol Scand. 1998;162:411-9.

52. Adair TH, Gay WJ, Montani JP. Growth regulation of the vascular system: evidence for a metabolic hypothesis. Am J Physiol. 1990;259:R393-404.

53. Bagher P, Segal SS. Regulation of blood flow in the microcirculation: Role of conducted vasodilation. Acta Physiol (Oxf). 2010.

54. Rooyackers OE, Nair KS. Hormonal regulation of human muscle protein metabolism. Ann Rev Nutr. 1997; 17:457-85.

55. Segal SS. Regulation of blood flow in the microcirculation. Microcirculation. 2005;12:33-45.

56. Biolo G, Declan Fleming R, Wolfe R. Physiologic hyperinsulinemia stimulates protein synthesis and enhances transport of selected amino acids in human skeletal muscle. J Clin Invest. 1995;95:811-9.

57. Garlick PJ, Grant I. Amino acid infusion increases the sensitivity of muscle protein synthesis in vivo to insulin. Effect of branched-chain amino acids. Biochem J. 1988;254:579-84.

58. Frayn KN, Maycock PF. Regulation of protein metabolism by a physiological concentration of insulin in mouse soleus and extensor digitorum longus muscles. Effects of starvation and scald injury. Biochem J. 1979;184:323-30.

59. Fujita S, Rasmussen BB, Cadenas JG, Grady JJ, Volpi E. Effect of insulin on human skeletal muscle protein synthesis is modulated by insulin-induced changes in muscle blood flow and amino acid availability. Am J Physiol Endocrinol Metab. 2006;291:E745-54.

60. Muniyappa R, lantorno M, Quon M. An integrated view of insulin resistance and endothelial dysfunction. Endocrinology and metabolism clinics of North America. 2008;37:685.

61. Phillips SM. Insulin and muscle protein turnover in humans: stimulatory, permissive, inhibitory, or all of the above? Am J Physiol Endocrinol Metab. 2008;295:E731.

62. Timmerman KL, Volpi E. Amino acid metabolism and regulatory effects in aging. Curr Opin Clin Nutr Metab Care. 2008;11:45-9.

63. Greenhaff PL, Karagounis LG, Peirce N, Simpson EJ, Hazell M, Layfield R, et al. Disassociation between the effects of amino acids and insulin on signaling, ubiquitin ligases, and protein turnover in human muscle. Am J Physiol Endocrinol Metab. 2008;295:E595-604.

64. Fujita S, Glynn EL, Timmerman KL, Rasmussen BB, Volpi E. Supraphysiological hyperinsulinaemia is necessary to stimulate skeletal muscle protein anabolism in older adults: evidence of a true age-related insulin resistance of muscle protein metabolism. Diabetologia. 2009;52:1889-98.

65. Meneilly GS, Elliot T, Bryer-Ash M, Floras JS. Insulin-mediated increase in blood flow is impaired in the elderly. J Clin Endocrinol Metab. 1995;80:1899-903.

66. Wilkes EA, Selby AL, Atherton PJ, Patel R, Rankin D, Smith K, et al. Blunting of insulin inhibition of proteolysis in legs of older subjects may contribute to age-related sarcopenia. Am J Clin Nutr. 2009;90:1343-50.

67. Rodriguez-Manas L, El-Assar M, Vallejo S, Lopez-Doriga P, Solis J, Petidier R, et al. Endothelial dysfunction in aged humans is related with oxidative stress and vascular inflammation. Aging cell. 2009;8:226-38.

68. Brandes R, Fleming I, Busse R. Endothelial aging. Cardiovascular research. 2005;66:286-94.

69. Nieuwdorp M, Meuwese MC, Mooij HL, Ince C, Broekhuizen LN, Kastelein JJ, et al. Measuring endothelial glycocalyx dimensions in humans: a potential novel tool to monitor vascular vulnerability. J Appl Physiol. 2008;104:845-52.

70. Weinbaum S, Tarbell JM, Damiano ER. The structure and function of the endothelial glycocalyx layer. Annu Rev Biomed Eng. 2007;9:121-67. 
71. Van Teeffelen JW, Brands J, Stroes ES, Vink H. Endothelial glycocalyx: sweet shield of blood vessels. Trends Cardiovasc Med. 2007;17:101-5.

72. Luft JH. The structure and properties of the cell surface coat. Int Rev Cytol. 1976;45:291-382.

73. Reitsma S, Slaaf DW, Vink H, van Zandvoort MA, oude Egbrink MG. The endothelial glycocalyx: composition, functions, and visualization. Pflugers Arch. 2007;454:345-59.

74. Zuurbier CJ, Demirci C, Koeman A, Vink H, Ince C. Short-term hyperglycemia increases endothelial glycocalyx permeability and acutely decreases lineal density of capillaries with flowing red blood cells. J Appl Physiol. 2005;99:1471-6.

75. Phillips S, Tipton K, Aarsland A, Wolf S, Wolfe R. Mixed muscle protein synthesis and breakdown after resistance exercise in humans. Am J Physiol. 1997;273:107.

76. Biolo G, Maggi SP, Williams BD, Tipton KD, Wolfe RR. Increased rates of muscle protein turnover and amino acid transport after resistance exercise in humans. Am J Physiol. 1995;268:E514-20.

77. Chesley A, MacDougall JD, Tarnopolsky MA, Atkinson SA, Smith K. Changes in human muscle protein synthesis after resistance exercise. J Appl Physiol (1985). 1992;73:1383-8.

78. Paddon-Jones D, Short KR, Campbell WW, Volpi E, Wolfe RR. Role of dietary protein in the sarcopenia of aging. Am J Clin Nutr. 2008;87:1562S-6S.

79. Nair KS. Aging muscle. Am J Clin Nutr. 2005;81:953-63.

80. Glover El, Phillips SM, Oates BR, Tang JE, Tarnopolsky MA, Selby A, et al. Immobilization induces anabolic resistance in human myofibrillar protein synthesis with low and high dose amino acid infusion. J Physiol. 2008;586:6049-61.

81. Breen L, Stokes KA, Churchward-Venne TA, Moore DR, Baker SK, Smith K, et al. Two weeks of reduced activity decreases leg lean mass and induces "anabolic resistance" of myofibrillar protein synthesis in healthy elderly. J Clin Endocrinol Metab. 2013;98:2604-12.

82. Wall BT, Gorissen SH, Pennings B, Koopman R, Groen BB, Verdijk LB, et al. Aging Is Accompanied by a Blunted Muscle Protein Synthetic Response to Protein Ingestion. PLoS One. 2015;10:e0140903. 


\section{Chapter}

\section{Postprandial protein handling:}

you are what you just ate

Bart B.L. Groen, Astrid M. Horstman, Henrike M. Hamer, Michiel de Haan, Janneau van Kranenburg, Jörgen Bierau, Martijn Poeze, Will K.W.H. Wodzig, Blake B. Rasmussen, Luc J.C. van Loon 


\section{Abstract}

\section{Background}

Protein turnover in skeletal muscle tissue is highly responsive to nutrient intake in healthy adults.

\section{Objective}

To provide a comprehensive overview of postprandial protein handling, ranging from dietary protein digestion and amino acid absorption, the uptake of dietary protein derived amino acids over the leg, the postprandial stimulation of muscle protein synthesis rates, to the incorporation of dietary protein derived amino acids in de novo muscle protein.

\section{Design}

12 healthy young males ingested $20 \mathrm{~g}$ intrinsically $\left[1^{13} \mathrm{C}\right]$-phenylalanine labeled protein. In addition, primed continuous L-[ring- $\left.{ }^{2} \mathrm{H}_{5}\right]$-phenylalanine, L-[ring- $\left.{ }^{2} \mathrm{H}_{2}\right]$-tyrosine, and $\mathrm{L}-\left[1-{ }^{13} \mathrm{C}\right]-$ leucine infusions were applied, with frequent collection of arterial and venous blood samples, and muscle biopsies throughout a $5 \mathrm{~h}$ postprandial period. Dietary protein digestion, amino acid absorption, splanchnic amino acid extraction, amino acid uptake over the leg, and subsequent muscle protein synthesis were measured within a single in vivo human experiment.

\section{Results}

$55.3 \pm 2.7 \%$ of the protein-derived phenylalanine was released in the circulation during the $5 \mathrm{~h}$ postprandial period. The postprandial rise in plasma essential amino acid availability improved leg muscle protein balance (from $-291 \pm 72$ to $103 \pm 66 \mu \mathrm{M} \cdot \mathrm{min}^{-1} \cdot 100 \mathrm{~mL}$ leg volume ${ }^{-1} ; P<0.001$ ). Muscle protein synthesis rates increased significantly following protein ingestion $(0.029 \pm 0.002 \mathrm{vs}$. $0.044 \pm 0.004 \% \cdot h^{-1}$ based upon the muscle protein bound L-[ring $\left.{ }^{2} \mathrm{H}_{5}\right]$-phenylalanine enrichments $(P<0.01))$, with substantial incorporation of dietary protein derived $\mathrm{L}-\left[1-{ }^{13} \mathrm{C}\right]$-phenylalanine into de novo muscle protein (from 0 to $0.0201 \pm 0.0025 \mathrm{MPE}$ ).

\section{Conclusion}

Ingestion of a single meal-like amount of protein allows $\sim 55 \%$ of the protein derived amino acids to become available in the circulation, thereby improving whole-body and leg protein balance. About $20 \%$ of the dietary protein derived amino acids released in the circulation are taken up in skeletal muscle tissue following protein ingestion, thereby stimulating muscle protein synthesis rates and providing precursors for de novo muscle protein synthesis. 


\section{Introduction}

It has been well established that protein turnover in skeletal muscle tissue is highly responsive to nutrient intake in healthy adults. Protein ingestion increases both muscle protein synthesis as well as muscle protein breakdown rates, albeit the latter to a lesser extent, resulting in a positive net muscle protein balance. ${ }^{1-3}$ The postprandial muscle protein synthetic and anti-proteolytic response to feeding is regulated on various levels, ranging from protein digestion and amino acid absorption, ${ }^{4,5}$ the postprandial rise in circulating insulin and subsequent increase in microvascular recruitment, ${ }^{6,7}$ amino acid uptake in skeletal muscle tissue, ${ }^{8}$ intramuscular anabolic signaling ${ }^{9,10}$ and myofibrillar muscle protein synthesis and breakdown. ${ }^{11}$ It has been proven difficult to define the impact of all of these variables on the anabolic response to protein feeding in an in vivo human setting.

To investigate dietary protein digestion and amino acid absorption kinetics, we have previously combined the ingestion of specifically produced intrinsically $\mathrm{L}-\left[1-{ }^{13} \mathrm{C}\right]-$ phenylalanine labeled milk protein ${ }^{12}$ with the continuous intravenous infusion of L-[ring- ${ }^{2} \mathrm{H}_{5}$ ]- phenylalanine. ${ }^{5,13-22}$ The use of intrinsically labeled protein allows us to determine the rate at which dietary protein derived amino acids enter the circulation and provides us with an estimate of splanchnic amino acid retention. ${ }^{21}$ Others have applied the AV-model ${ }^{23}$ to assess postprandial amino acid uptake and release by measuring arterio-venous differences in plasma amino acid concentrations over the leg combined with the assessment of leg blood flow. ${ }^{24-26}$ Postprandial stimulation of muscle protein synthesis is typically assessed by the measurement of the increase in muscle protein bound L-[ring- $\left.{ }^{2} \mathrm{H}_{5}\right]$-phenylalanine following a primed continuous infusion of L-[ring- $\left.{ }^{2} \mathrm{H}_{5}\right]$-phenylalanine with the plasma or muscle free L-[ring- $\left.{ }^{2} \mathrm{H}_{5}\right]-$ phenylalanine being used as precursor pool. ${ }^{4,27,28}$ To overcome the methodological limitations associated with the non-steady state and precursor pool dilution when assessing postprandial muscle protein synthesis, Reitelseder et al. ${ }^{29}$ introduced the assessment of postprandial muscle protein synthesis rates by the primed continuous infusion of $\mathrm{L}-\left[1-{ }^{13} \mathrm{C}\right]$-leucine combined with the ingestion of intrinsically $\mathrm{L}-\left[1-{ }^{13} \mathrm{C}\right]$-leucine labeled protein ( 5-10 MPE), thereby preventing a postprandial decline in plasma precursor pool enrichment. By the production of intrinsically labeled protein with high $\mathrm{L}-\left[1-{ }^{13} \mathrm{C}\right]$-phenylalanine enrichment levels ( 30-40 MPE), we have been able to assess the metabolic fate of dietary protein derived phenylalanine by directly measuring postprandial L- $\left[1-{ }^{13} \mathrm{C}\right]$-phenylalanine incorporation in muscle protein. ${ }^{21,30,31}$ Recently, we introduced the production and application of L-[1- $\left.{ }^{13} \mathrm{C}\right]$-leucine $(\sim 10 \mathrm{MPE})$ and $\mathrm{L}-\left[1-{ }^{13} \mathrm{C}\right]-$ phenylalanine ( $35 \mathrm{MPE})$ labeled milk proteins. ${ }^{32}$ Combining the ingestion of intrinsically $\mathrm{L}-\left[1-{ }^{13} \mathrm{C}\right]$-leucine and $\mathrm{L}-\left[1-{ }^{13} \mathrm{C}\right]$-phenylalanine labeled protein with intravenous $\mathrm{L}-\left[1-{ }^{13} \mathrm{C}\right]$-leucine and $\mathrm{L}$-[ring- $\left.{ }^{2} \mathrm{H}_{5}\right]$-phenylalanine infusion allows the assessment of dietary protein digestion and amino acid absorption kinetics, splanchnic extraction of protein derived amino acids, muscle protein synthesis rates, as well as the 
metabolic fate of dietary protein derived amino acids for de novo muscle protein synthesis. ${ }^{33}$.

We hypothesized that a substantial part of the ingested protein derived amino acids are directly used as amino acid precursors to support the postprandial rise in de novo muscle protein synthesis rate. By applying a combination of methods we assessed in vivo dietary protein digestion and subsequent amino acid absorption, the appearance of dietary protein derived amino acids in the circulation, the uptake and release of amino acids over the leg, the postprandial stimulation of muscle protein synthesis as well as the use of protein derived amino acids for de novo muscle protein synthesis within one single experiment. Twelve healthy males were selected to participate in this study in which these parameters were assessed prior to and after ingesting $20 \mathrm{~g}$ intrinsically labeled casein. Intravenous amino acid tracer infusions were applied with venous and arterial blood and muscle biopsy samples being collected frequently. This study quantifies postprandial protein handling and the subsequent use of dietary protein derived amino acids for de novo muscle protein synthesis in vivo in humans. Consequently, this work provides a complete and comprehensive insight into the fact that you actually are what you just ate.

\section{Methods}

\section{Subjects}

Twelve healthy, young males (age: $23 \pm 1 \mathrm{y} ; \mathrm{BMI}: 22.6 \pm 0.3 \mathrm{~kg} \cdot \mathrm{m}^{-2}$ ) were recruited, pretested and selected to participate in the present study between March and November 2012. Subjects' characteristics are presented in Table 2.1. The power calculation was based upon a desired $10 \%$ increase of the fractional synthetic rate (FSR) from the post-absorptive to the postprandial state following the ingestion of $20 \mathrm{~g}$ of protein. ${ }^{18}$ The effect size we were looking to detect is 1.16 , with an $\alpha=0.05$ and a power of 0.90 , the a priori power calculation resulted in a total sample size of 12 subjects. All subjects were informed of the nature and possible risks of the experimental procedures, before their written informed consent was obtained. This study was approved by the Medical Ethical Committee of the Maastricht University Medical Centre and conforms to the principles outlined in the declaration of Helsinki for use of human subjects and tissue.

\section{Pretesting}

Following an overnight fast, participants arrived at the laboratory at 8:30 AM by car or public transport. Blood pressure was measured after which a baseline blood sample was collected to determine blood count, plasma electrolytes, liver (ALAT) and renal (creatinine and ureum) function, blood $\mathrm{HbA1c}$ levels, and plasma glucose 
concentrations. Subsequently, an oral glucose tolerance test was performed to determine oral glucose intolerance and/or the presence of type 2 diabetes according to American Diabetes Association Guidelines. ${ }^{34}$ OGIS values were based on plasma glucose and insulin concentrations from the $2 \mathrm{~h}$ oral glucose tolerance test. Calculations were used as described by Mari et al.. ${ }^{35}$ After glucose tolerance testing, leg volume was assessed as described by Jones and Pearson ${ }^{36}$ with circumferences and segmental leg lengths taken at the gluteal furrow, mid-thigh, above the knee, maximum knee, below the knee, as well as maximum calf and minimum ankle circumferences. ${ }^{36}$ Body composition was measured with DXA (Lunar Prodigy Advance; GE Health Care, Madison, WI). The system's software package (en-CORE 2005, version 9.15.00) was used to determine whole body and regional lean mass, fat mass and bone mineral content. Healthy subjects with screening results within normal limits and stable body weight for at least 3 months were included.

Table 2.1 Subjects' characteristics.

\begin{tabular}{lc}
\hline & Subjects $(n=12)$ \\
\hline Age $(\mathrm{y})$ & $23 \pm 1$ \\
Weight $(\mathrm{kg})$ & $72.5 \pm 1.8$ \\
BMI (kg) & $22.6 \pm 0.3$ \\
HbA1c (\%) & $5.2 \pm 0.1$ \\
Fasting glucose $\left(\mathrm{mmol} \cdot \mathrm{L}^{-1}\right)$ & $4.7 \pm 0.2$ \\
OGIS & $489 \pm 19$ \\
Blood pressure systolic $(\mathrm{mmHg})$ & $123 \pm 2$ \\
Blood pressure diastolic $(\mathrm{mmHg})$ & $63 \pm 2$ \\
Leg volume (L) & $9.2 \pm 0.4$ \\
Leg mass (kg) & $10.1 \pm 0.3$ \\
Appendicular lean mass $(\mathrm{kg})$ & $27.0 \pm 0.9$ \\
Lean body mass $(\mathrm{kg})$ & $58.2 \pm 1.7$ \\
\hline
\end{tabular}

Values are expressed as means \pm SEM. HbA1c, glycated hemoglobin; OGIS, Oral Glucose Insulin Sensitivity.

\section{Study design}

The experimental protocol is outlined in Figure 2.1. Each subject participated in one experiment, in which postprandial protein handling was studied after the ingestion of $20 \mathrm{~g}$ intrinsically $\mathrm{L}-\left[1-{ }^{13} \mathrm{C}\right]$ - phenylalanine and $\mathrm{L}-\left[1-{ }^{13} \mathrm{C}\right]$-leucine labeled protein. Antecubital venous and femoral arterial and venous lines were inserted ${ }^{37}$ for intravenous L-[1- $\left.{ }^{13} \mathrm{C}\right]$-leucine, L-[ring- $\left.{ }^{2} \mathrm{H}_{2}\right]$-tyrosine and L-[ring- $\left.{ }^{2} \mathrm{H}_{5}\right]$-phenylalanine tracer and indocyanine green infusions ${ }^{38}$ and arterial and venous blood sampling. Muscle biopsy tissue samples were collected from the M. vastus lateralis. 


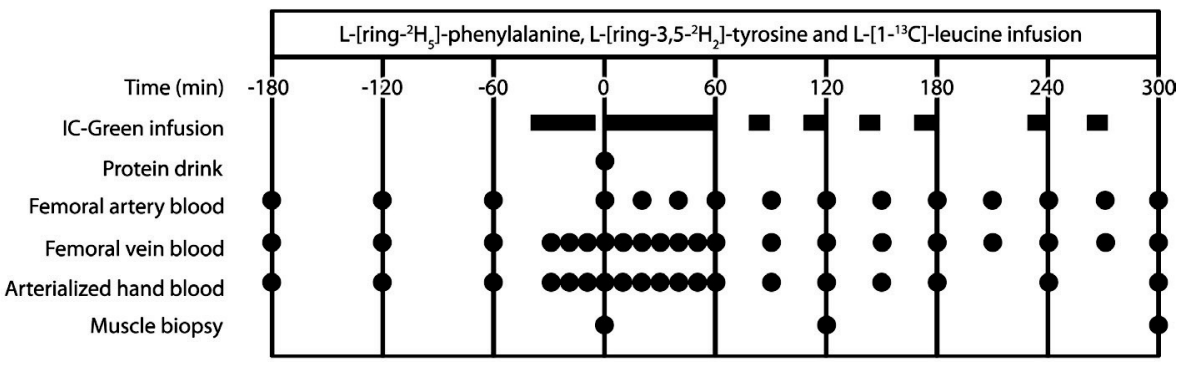

Figure 2.1 Outline of study protocol.

\section{Protocol}

All subjects were instructed to refrain from strenuous physical exercise for 3 days prior to testing. Subjects refrained from alcohol and caffeine, and consumed a standardized dinner $\left(32.5 \pm 0.7 \mathrm{~kJ} \cdot \mathrm{kg}^{-1}\right.$ body weight; providing 16 energy percent (en\%) protein, 33 en\% carbohydrate, and 51 en\% fat) the evening prior to testing. The following morning, subjects arrived at the laboratory at 7:30 AM by car or public transportation. A polyethylene catheter was inserted into an antecubital vein for intravenous isotope tracer infusion. A second catheter was inserted into a dorsal hand vein of the contralateral arm and placed in a hot-box $\left(60^{\circ} \mathrm{C}\right)$ for arterialized blood sampling to measure background indocyanine green, ${ }^{38}$ glucose, and insulin concentrations. Subsequently, the other 2 polyethylene catheters were inserted into the femoral artery and vein of the right leg for blood sampling. Ultrasound imaging was used to confirm safe insertion of the femoral lines. The arterial catheter was also used for the infusion of indocyanine green (IC-Green; Akorn, Lake forest, II). Following basal blood collection from the heated hand vein, femoral artery and femoral vein ( $t=-180 \mathrm{~min}$ ), the plasma phenylalanine, tyrosine and leucine pools were primed with a single intravenous dose of $2.000,0.615$ and $3.99 \mu \mathrm{mol} \cdot \mathrm{kg}^{-1}$, respectively, after which continuous tracer infusion $\left(0.050 \mu \mathrm{mol} \cdot{ }^{1} \mathrm{~kg} \cdot \mathrm{min}^{-1} \quad \mathrm{~L}\right.$-[ring- ${ }^{2} \mathrm{H}_{5}$ ]-phenylalanine, $0.015 \mu \mathrm{mol} \cdot{ }^{1} \mathrm{~kg} \cdot \mathrm{min}^{-1} \quad \mathrm{~L}-\left[\mathrm{ring}-{ }^{2} \mathrm{H}_{2}\right]-$ tyrosine, and $0.130 \mu \mathrm{mol}^{1} \mathrm{~kg} \cdot \mathrm{min}^{-1} \mathrm{~L}-\left[1-{ }^{13} \mathrm{C}\right]$-leucine) was administrated using a calibrated IVAC 560 pump (San Diego, USA) until the end of the experiment. After resting in a supine position for $60 \mathrm{~min}$, an arterialized blood sample from the heated hand vein, and an arterial and venous blood sample from the catheterized leg were drawn at $t=-120$ and $-60 \mathrm{~min}$. Subsequently, indocyanine green was infused in the femoral artery $(1.0 \mathrm{mg} / \mathrm{min})$ from $t=-45 \mathrm{~min}$ until the end of the experiment $(t=300 \mathrm{~min})$ with intervals as presented in Figure 2.1. After collecting blood samples from the heated hand vein, femoral artery, and femoral vein at $\mathrm{t}=0 \mathrm{~min}$, subjects received the test-drink containing $20 \mathrm{~g}$ intrinsically labeled casein protein and were asked to consume the drink within $5 \mathrm{~min}$. Following the protein drink, blood samples from the heated hand vein, femoral artery, and femoral vein were collected at time points $t=20$, 
40, 60, 90, 120, 150, 180, 210, 240, 270 and 300 min. Muscle biopsies were obtained at $\mathrm{t}=0,120$ and $300 \mathrm{~min}$ after protein ingestion, using the percutaneous needle biopsy technique ${ }^{39}$. Muscle samples were dissected carefully and freed from any visible nonmuscle material and immediately frozen in liquid nitrogen and stored at $-80^{\circ} \mathrm{C}$ until further analysis. After the third biopsy, all infusions were stopped, the catheters were removed, and the subjects were fed and discharged $\sim 3 \mathrm{~h}$ after removal of the femoral catheters.

\section{Plasma analysis}

Plasma glucose (Glucose HK CP, ABX Diagnostics, ref. A11A01667, Montpellier, France) concentrations were analyzed with a COBAS-FARA semi-automatic analyzer (Roche, Basel, Switzerland). Plasma insulin concentrations were determined by radioimmunoassay (Millipore, ref. HI-14K, Billerica, USA). ICG concentrations in plasma were determined spectrofotometrically as previously described. ${ }^{38}$ For determination of plasma amino acid concentrations, $10 \mu \mathrm{L}$ of plasma was mixed with $1500 \mu \mathrm{L} 0.5 \mathrm{mM}$ Tridecafluoroheptanoic acid (TDFHA) (Sigma, Zwijndrecht, The Netherlands) in water and $10 \mu \mathrm{L}$ of the internal standard solution containing stable isotope-labeled amino acids (Cambridge Isotope Laboratories, Inc., Andover, USA) in $0.1 \mathrm{M} \mathrm{HCl}$. Amino acid profiles were determined using ultra-performance liquid chromatography tandem mass spectrometry (UPLC-MS/MS) as described previously. ${ }^{40}$ For measurement of plasma phenylalanine, tyrosine and leucine concentrations as well as $L-\left[1-{ }^{13} \mathrm{C}\right]$-phenylalanine, $\mathrm{L}-\left[1-{ }^{13} \mathrm{C}\right]$-tyrosine, L-[ring- $\left.{ }^{2} \mathrm{H}_{5}\right]$-phenylalanine, L-[ring- $\left.{ }^{2} \mathrm{H}_{4}\right]$-tyrosine and $\mathrm{L}-\left[\right.$ ring- $\left.{ }^{2} \mathrm{H}_{2}\right]-$ tyrosine enrichments, plasma amino acids were derivatized to their t-butyldimethylsilyl (TBDMS) derivatives after the addition of an internal standard. Their concentrations and ${ }^{13} \mathrm{C}$ and/or ${ }^{2} \mathrm{H}$ enrichments were determined by electron ionization gas chromatography-mass spectrometry (GC-MS, Agilent 6890N GC/5973N MSD Little Falls, USA) using selected ion monitoring of masses 336, 337 and 341 for unlabeled and labeled $\left(\mathrm{L}-\left[1-{ }^{13} \mathrm{C}\right]\right.$ and $\mathrm{L}-\left[\right.$ ring $\left.\left.-{ }^{2} \mathrm{H}_{5}\right]\right)$ phenylalanine, respectively. Masses 466, 467, 468 and 470 were assessed for unlabeled and labeled $\left(\mathrm{L}-\left[1-{ }^{13} \mathrm{C}\right]\right.$, L-[ring- $\left.{ }^{2} \mathrm{H}_{2}\right]$, and $\mathrm{L}$-[ring- $\left.{ }^{2} \mathrm{H}_{4}\right]$ ) tyrosine and masses 302 and 303 were assessed for unlabeled and labeled $\left(\mathrm{L}-\left[1-{ }^{13} \mathrm{C}\right]\right.$ leucine), respectively. Albumin was extracted from blood samples by adding $20 \%$ perchloric acid (PCA). Samples were centrifuged at $3500 \mathrm{~g}$ at $4^{\circ} \mathrm{C}$ for $20 \mathrm{~min}$ after which the supernatant was removed. The mixed plasma protein pellet was washed and lyophilized to dryness. Amino acids were liberated by adding $6 \mathrm{~mol} \mathrm{~L}^{-1} \mathrm{HCl}$ and heated at $120^{\circ} \mathrm{C}$ for 15 to $18 \mathrm{~h}$. Thereafter, the hydrolyzed mixed plasma protein samples were processed via the same procedures as the muscle protein bound samples (described in the next paragraph). We applied standard regression curves in all isotopic enrichment analyses to assess linearity of the mass spectrometer and to control for the loss of tracer. Enrichments (MPE) were calculated according to Biolo et al. ${ }^{41}$ to correct for the presence naturally occurring isotopes. 


\section{Muscle analyses}

For measurement of $\mathrm{L}-\left[1-{ }^{13} \mathrm{C}\right]$-leucine, $\mathrm{L}-\left[1-^{13} \mathrm{C}\right]$-phenylalanine and $\mathrm{L}-\left[\right.$ ring- $\left.{ }^{2} \mathrm{H}_{5}\right]-$ phenylalanine enrichment in the muscle free and muscle protein bound amino acid pool, 55 mg wet muscle tissue was freeze dried. Collagen, blood, and other non-muscle fiber materials were removed from the muscle fibers under a light microscope. The isolated muscle fiber mass was weighed and 35 volumes ( $7 x$ wet weight of isolated muscle fibers $x$ wet-to-dry ratio $5: 1$ ) of ice-cold $2 \%$ perchloric acid (PCA) was added. Thereafter, the tissue was homogenized and centrifuged, with the supernatant being collected and processed in the same manner as the plasma samples, such that intracellular free $\mathrm{L}-\left[1-{ }^{13} \mathrm{C}\right]$-leucine, $\mathrm{L}-\left[1-{ }^{13} \mathrm{C}\right]$-phenylalanine and $\mathrm{L}$-[ring- $\left.{ }^{2} \mathrm{H}_{5}\right]-$ phenylalanine enrichments could be measured using their TBDMS derivatives on a GCMS. The protein pellet was washed for 3 additional $1.5 \mathrm{~mL}$ washes of $2 \%$ PCA, dried, and the hydrolyzed protein fraction was dried under a nitrogen steam while heated to $120^{\circ} \mathrm{C}$, then $50 \%$ acetic acid solution was added, and the hydrolyzed protein was passed over a Dowex exchange resin (AG 50W-X8, 100-200 mesh hydrogen form: Bio-Rad, Hercules, CA) using $2 \mathrm{M} \mathrm{NH}{ }_{4} \mathrm{OH}$. The eluate was divided over 2 vials for separate measurement of L-[1- $\left.{ }^{13} \mathrm{C}\right]$-leucine and $\mathrm{L}-\left[1-{ }^{13} \mathrm{C}\right]$-phenylalanine (GC-C-IRMS) and L-[ring${ }^{2} \mathrm{H}_{5}$ ]-phenylalanine (GC-MS) as described previously [30]. In short, L-[1- $\left.{ }^{13} \mathrm{C}\right]$-leucine and $\mathrm{L}-\left[1-{ }^{13} \mathrm{C}\right]$-phenylalanine were derivatized to their $\mathrm{N}(\mathrm{O}, \mathrm{S})$-ethoxycarbonyl ethyl esters and measured using Isotope Ratio Mass Spectrometer (IRMS, Thermo Scientific, GC Isolink/Mat 253) and L-[ring- ${ }^{2} \mathrm{H}_{5}$ ]-phenylalanine became a TBDMS derivative of purified $\beta$-phenylethylamine produced by enzymatic decarboxylation, solvent extraction and was measured on the GC-MS. Standard regression curves were applied to assess linearity of the mass spectrometer and to control for the loss of tracer.

\section{Calculations}

Whole-body amino acid kinetics (expressed in $\mathrm{nmol}$ phenylalanine $\cdot \mathrm{kg} \mathrm{BW}^{-1} \cdot \mathrm{min}^{-1}$ ) in non-steady state conditions were calculated from the ingestion of $L-\left[1-{ }^{13} \mathrm{C}\right]-$ phenylalanine labeled protein with primed intravenous infusion of L-[ring- $\left.{ }^{2} \mathrm{H}_{5}\right]$ phenylalanine and L-[ring-3, $5-{ }^{2} \mathrm{H}_{2}$ ]-tyrosine, with frequent venous and arterial blood sampling. Total, exogenous, and endogenous phenylalanine rates of appearance ( $R a)$, as well as plasma phenylalanine availability (i.e, the fraction of dietary protein-derived phenylalanine that appeared in the systemic circulation, Phe plasma) were calculated using modified Steele's equations. ${ }^{42,43}$ Furthermore, total rate of phenylalanine disappearance (Rd), utilization of phenylalanine for protein synthesis, and phenylalanine hydroxylation (first step of phenylalanine conversion to tyrosine) were calculated. Whole-body net protein balance was calculated by subtracting protein synthesis from endogenous phenylalanine appearance ( $\mathrm{Ra}$ ) and presented as the weighted mean over the $5 \mathrm{~h}(\mathrm{t}=0-300 \mathrm{~min})$ postprandial period. 
Phenylalanine and leucine kinetics were also used to study the two-pool and three-pool models. ${ }^{44}$ All calculations in this manuscript are based on the methodology as presented by Biolo and colleagues. ${ }^{23}$ The two-pool model has been used by a number of research groups, thus allowing for a comparison of our results with previous results from our lab ${ }^{18,30}$ and data collected by others. ${ }^{45}$ Phenylalanine was selected as the primary amino acid of interest as it is not metabolized in skeletal muscle tissue. Historically, leucine has mainly been used as the amino acid of interest ${ }^{22,41,46}$ and, therefore, measurements were performed based upon the phenylalanine and/or leucine tracer where appropriate. With the two-pool model, phenylalanine enrichments and concentrations in the femoral artery and vein were used to assess amino acid uptake over the leg. These parameters are based on the extraction of the labeled phenylalanine from the femoral artery, the appearance of phenylalanine in the femoral vein, and the net arteriovenous difference of the phenylalanine concentrations. ${ }^{44}$ Thus this model allows for the assessment of plasma phenylalanine kinetics across the leg, providing no particular insight into its intramyocellular kinetics. The three-pool model is an expansion of the two-pool model and relies not only on the measurement of the amino acid enrichments and concentrations in the femoral artery and vein, but also on the direct measurement of the amino acid enrichment in muscle free tissue water. This allows for the assessment of intracellular phenylalanine use for protein synthesis and release from protein breakdown. In addition, it is possible to calculate the rate of phenylalanine and leucine transport from the artery into the tissue and from the tissue into venous blood. ${ }^{23,45}$ The two- and three-pool models share the following parameters:

1. Delivery to the leg $=\mathrm{F}_{\text {in }}=C_{A} \cdot B F$

2. Output from the leg $=\mathrm{F}_{\text {out }}=C_{V} \cdot B F$

3. Leg net balance $(\mathrm{NB})=\left(C_{A}-C_{v}\right) \cdot B F$

The other kinetic parameters of the three-pool method are calculated as follows:

4. Total rate of appearance in the $\operatorname{leg}\left(\right.$ total $\left._{\mathrm{a}}\right)=\left(C_{A} \cdot \frac{E_{A}}{E_{V}}\right) \cdot B F$

5. Release from the the $\operatorname{leg}\left(\operatorname{leg} \mathrm{R}_{\mathrm{a}}\right)=\operatorname{total} \mathrm{R}_{\mathrm{a}}-\mathrm{F}_{\text {in }}=B F \cdot C_{A} \cdot\left(\left(\frac{E_{A}}{E_{V}}\right)-1\right)$

6. Rate of disappearance in the leg $\left(\right.$ total $\left._{\mathrm{d}}\right)=$ total $\mathrm{R}_{\mathrm{a}}+\mathrm{NB}=B F \cdot\left(\left(C_{A}-\left(\frac{E_{A}}{E_{V}}\right)\right)-C_{V}\right)$ 
where $C_{A}$ and $C_{V}$ are the plasma phenylalanine or leucine concentrations in the femoral artery and vein, respectively; $E_{A}$ and $E_{V}$ are phenylalanine or leucine enrichments, expressed as Mole Percentage Excess (MPE), in the femoral arterial and venous plasma, respectively; and $\mathrm{BF}$ is leg blood flow as calculated from the steady-state ICG concentration values in the femoral and antecubital veins, as described elsewhere. ${ }^{47}$ Data are expressed in $\mathrm{nmol}$ per min per $100 \mathrm{~mL}$ of leg volume. The specific parameters of the three-pool model were calculated as follows:

7. Muscle inward transport $=\mathrm{F}_{\mathrm{M}, \mathrm{A}}=\left(\left(C_{V} \cdot\left(\frac{E_{M}-E_{V}}{E_{A}-E_{M}}\right)\right)+C_{A}\right) \cdot B F$

8. Muscle outward transport $=\mathrm{F}_{\mathrm{V}, \mathrm{M}}=\left(\left(C_{V} \cdot\left(\frac{E_{M}-E_{V}}{E_{A}-E_{M}}\right)\right)+C_{V}\right) \cdot B F$

9. Arteriovenous shunting $=F_{V, A}=F_{i n}-F_{M, A}$

10. Muscle protein breakdown $=F_{M, O}=F_{M, A} \cdot\left(\left(\frac{E_{A}}{E_{M}}\right)-1\right)$

11. Muscle protein synthesis $=F_{O, M}=F_{M, O}+N B$

Where $E_{M}$ is phenylalanine or leucine enrichment, expressed as Mole Percentage Excess (MPE), in the muscle. Additionally, we calculated the intracellular phenylalanine and leucine availability as the sum of transport into the muscle $F_{M, A}$ and the intracellular $R_{a}$ from breakdown $\mathrm{F}_{\mathrm{M}, \mathrm{O}}$ :

12. Intracellular amino acid availability $=F_{M, A}+F_{M, O}$

We also calculated the fractional synthetic rate (FSR) of mixed muscle protein by measuring the incorporation rate of the phenylalanine or leucine tracer into mixed muscle protein $\left(\Delta \mathrm{E}_{\mathrm{p}} / \mathrm{t}\right)$ using the precursor-product model to calculate muscle protein synthesis rates:

13. $\mathrm{FSR}=\left(\frac{\Delta E_{P}}{t}\right) /\left(\frac{E_{M 1}+E_{M 2}}{2}\right) \cdot 60 \cdot 100$

Where $\Delta \mathrm{E}_{\mathrm{p}}$ is the change in protein-bound phenylalanine or leucine enrichment between two sequential biopsies, $t$ is the time between the biopsies, and $E_{M(1)}$ and $E_{M(2)}$ are the phenylalanine or leucine enrichments in the muscle free or plasma pool. Data are expressed as percent per hour. 


\section{Statistics}

Twelve volunteers were included in the present experiment. All results are expressed as means \pm standard error of the mean (SEM). Effect of time was calculated by repeated measures analysis, using a mixed model with unstructured covariance matrix. These calculations were performed using the procedure MIXED of SAS (version 9.3). Overall time effect and comparisons between the time-points are described. Where measurements in time are compared with those at the basal level ( $t=0 \mathrm{~min}$ ), a Dunnett test was applied, otherwise the LSD-test. In the case measurements were not repeated in time, e.g. baseline subject characteristics, a (independent) t-test was applied. Twosided tests were applied, and statistical significance was set at $P<0.05$.

\section{Results}

\section{Leg blood flow}

Blood flow averaged $6.0 \pm 0.4 \mathrm{~mL} \cdot \mathrm{min}^{-1} \cdot 100 \mathrm{~mL}$ leg volume $\mathrm{m}^{-1}$ in the basal state and did not change during the early $\left(6.2 \pm 0.5 \mathrm{~mL} \cdot \mathrm{min}^{-1} \cdot 100 \mathrm{~mL}\right.$ leg volume $\left.{ }^{-1}\right)$ or late $(5.6 \pm 0.3$ $\mathrm{mL} \cdot \mathrm{min}^{-1} \cdot 100 \mathrm{~mL}$ leg volume ${ }^{-1}$ ) postprandial phase when compared to basal values ( $P=0.92$ and $P=0.10$, respectively). Median blood flow during the entire postprandial phase averaged $5.8 \pm 0.4 \mathrm{~mL} \cdot \mathrm{min}^{-1} \cdot 100 \mathrm{~mL}$ leg volume ${ }^{-1}$ and was applied for all calculations.

\section{Plasma glucose and insulin concentrations}

Fasting plasma glucose and insulin levels averaged $4.83 \pm 0.10 \mathrm{mmol} \cdot \mathrm{L}^{-1}$ and $10.2 \pm 0.7$ $\mathrm{mU} \cdot \mathrm{mL}^{-1}$, respectively. Following protein ingestion, glucose concentrations significantly increased during the early postprandial phase $\left(\mathrm{t}=0-120 \mathrm{~min} ; 5.06 \pm 0.08 \mathrm{mmol} \cdot \mathrm{L}^{-1}\right.$ $(P=0.014))$ and returned to baseline values $\left(\mathrm{t}=120-300 \mathrm{~min} ; 4.83 \pm 0.07 \mathrm{mmol} \cdot \mathrm{L}^{-1}\right.$ $(P=0.992))$ during the late stages of the $5 \mathrm{~h}$ postprandial period. Plasma insulin concentrations increased upon protein ingestion in the early postprandial phase $\left(13.1 \pm 1.2 \mathrm{mU} \cdot \mathrm{L}^{-1} ; P<0.01\right)$ and declined over time with average values of $8.5 \pm 0.8 \mathrm{mU} \cdot \mathrm{L}^{-1}$ observed during the late postprandial phase $(P=0.014)$.

\section{Plasma amino acid concentrations}

Arterial and venous plasma phenylalanine, leucine, and essential amino acid (EAA) concentrations over time are shown in Figures $2.2 \mathrm{~A}, \mathrm{C}$ and $\mathrm{E}$, respectively. After ingestion of the intrinsically labeled casein protein, plasma amino acid concentrations increased rapidly and remained significantly elevated compared to basal values during the entire postprandial phase $(P<0.001)$. Peak arterial plasma phenylalanine, leucine and EAA concentrations averaged $66 \pm 2,220 \pm 11$ and $1112 \pm 77 \mu \mathrm{mol} \cdot \mathrm{L}^{-1}$, respectively. 


\section{Phenylalanine}
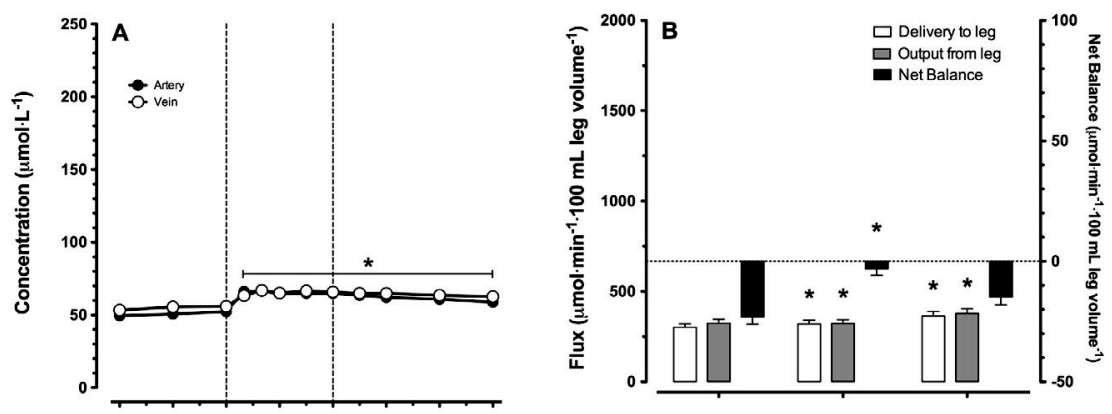

\section{Leucine}
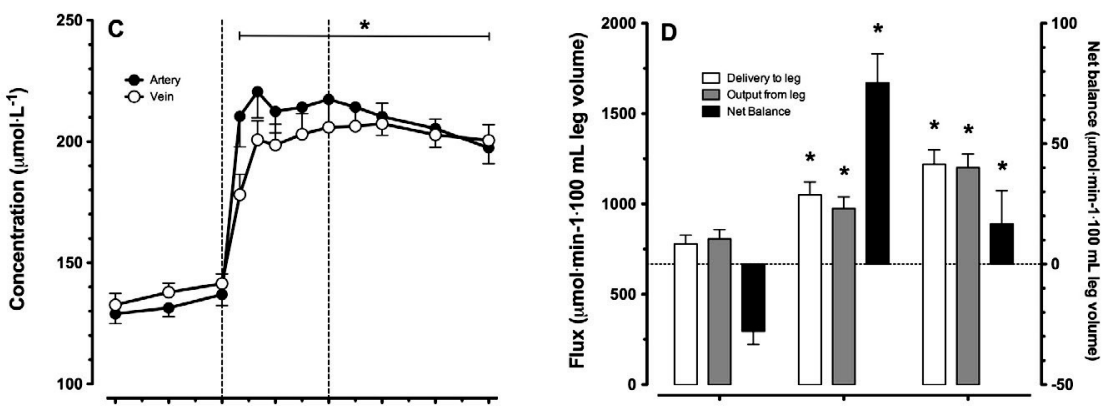

Essential amino acids
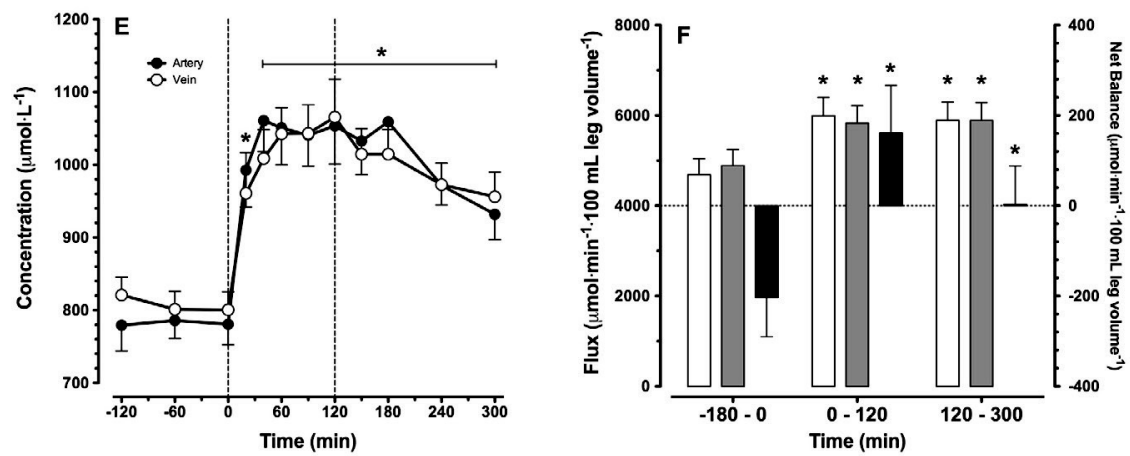

Figure 2.2 Amino acid concentrations and leg net balances. Arterial and venous plasma amino acid concentrations ( $A, C, E)$ and delivery, output and net balance over the leg $(B, D, F)$. Values are expressed as means \pm SEM. $*$ Indicates a significant difference compared to baseline level $(\mathrm{t}=0$ $\min ), P<0.05$.

Peak venous plasma phenylalanine and leucine concentrations averaged $67 \pm 2,207 \pm 8$ and $1080 \pm 50 \mu \mathrm{mol} \cdot \mathrm{L}^{-1}$, respectively. Phenylalanine and leucine delivery to the leg, 
output from the leg, as well as leg net balance are presented in Figures 2.2B, D and F, respectively. Phenylalanine, leucine and total EAA balance increased following protein ingestion, becoming positive during the early and/or late stages of the postprandial phase. All changes are significant compared to basal values, except for phenylalanine net balance during the later stages of the postprandial phase $(P=0.226)$.

\section{Plasma amino acid enrichments}

Continuous infusions with $\mathrm{L}-\left[\right.$ ring- $\left.{ }^{2} \mathrm{H}_{5}\right]$-phenylalanine and $\mathrm{L}-\left[1-{ }^{13} \mathrm{C}\right]$-leucine were applied from $\mathrm{t}=-180$ until $\mathrm{t}=300 \mathrm{~min}$. Intrinsically $\mathrm{L}-\left[1-{ }^{13} \mathrm{C}\right]$-phenylalanine and $\mathrm{L}-\left[1-{ }^{13} \mathrm{C}\right]$-leucine labeled casein was ingested at $\mathrm{t}=0 \mathrm{~min}$. Plasma tracer enrichments from the infused and/or ingested amino acid tracers sampled from the femoral artery and vein are presented in Figures 2.3A-C. Basal arterial and venous L-[ring- ${ }^{2} \mathrm{H}_{5}$ ]-phenylalanine enrichments averaged $7.43 \pm 0.19$ and $5.67 \pm 0.15 \mathrm{MPE}$, respectively. Basal arterial and venous $\mathrm{L}-\left[1-{ }^{13} \mathrm{C}\right]$-leucine enrichments averaged $6.05 \pm 0.12$ and $4.64 \pm 0.10 \mathrm{MPE}$, respectively. Average arterial L-[ring- $\left.{ }^{2} \mathrm{H}_{5}\right]$-phenylalanine enrichments during the early and late postprandial phase were $11 \pm 2$ and $3 \pm 2 \%$ lower than enrichments observed in the basal state $(P<0.001$ and $P=0.18$, respectively). After protein ingestion arterial and venous plasma L-[1-13 C]-phenylalanine enrichments increased rapidly, reaching peak levels of $8.99 \pm 0.71$ and $7.30 \pm 0.65 \mathrm{MPE}$ after 90 and $120 \mathrm{~min}$, respectively (Figure 2.3B). $\mathrm{L}-\left[1-{ }^{13} \mathrm{C}\right]$-leucine entered the circulation via intravenous infusion and followed digestion and amino acid absorption of the ingested $\mathrm{L}-\left[1-{ }^{13} \mathrm{C}\right]$-phenylalanine and $\mathrm{L}-\left[1-{ }^{13} \mathrm{C}\right]$-leucine labeled protein. After ingestion, small but significant increases in plasma $\mathrm{L}-\left[1-{ }^{13} \mathrm{C}\right]-$ leucine enrichments were observed during the early $(+0.47 \pm 0.07 \mathrm{MPE})$ and late stages $(+1.13 \pm 0.13 \mathrm{MPE})$ of the postprandial period (both $P<0.001)$. Peak arterial and venous plasma L- $\left[1-{ }^{13} \mathrm{C}\right]$-leucine enrichments were observed 90 and $150 \mathrm{~min}$ after protein ingestion and averaged $7.44 \pm 0.17$ and $6.38 \pm 0.17 \mathrm{MPE}$, respectively (Figure $2.3 \mathrm{C}$ ).
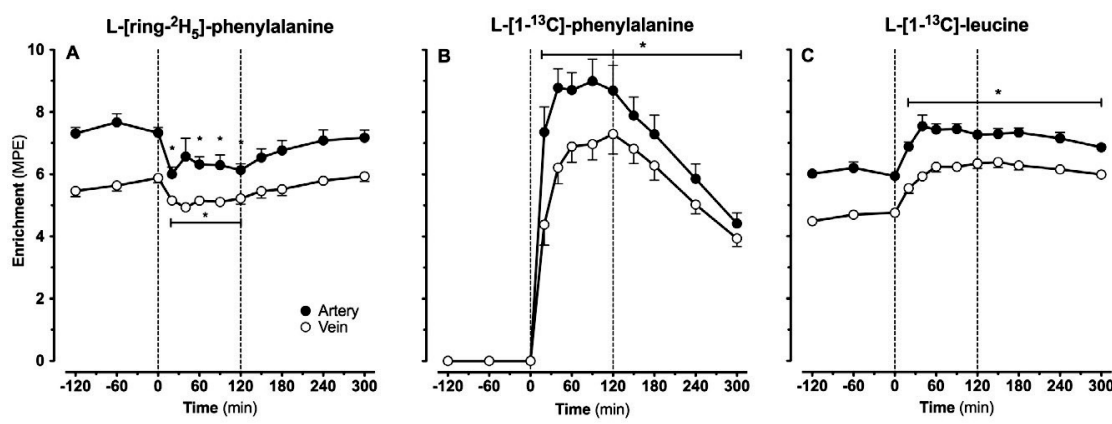

Figure 2.3 Amino acid enrichments. Arterial and venous plasma L-[ring- $\left.{ }^{2} \mathrm{H}_{5}\right]-$ phenylalanine $(A), \mathrm{L}-\left[1-{ }^{13} \mathrm{C}\right]-$ phenylalanine (B) and $\mathrm{L}-\left[1-{ }^{13} \mathrm{C}\right]$-leucine (C) enrichments. Intrinsically labeled protein was ingested at $\mathrm{t}=0 \mathrm{~min}$. Values are expressed as means $\pm \mathrm{SEM} . *$ Indicates a significant difference compared to baseline level ( $\mathrm{t}=0 \mathrm{~min}), P<0.05$. 


\section{Plasma amino acids kinetics}

Whole body plasma amino acid kinetics are presented in Figures 2.4A-D. Immediately after protein ingestion, exogenous $L-\left[1-{ }^{13} \mathrm{C}\right]$-phenylalanine started to appear in the circulation. Exogenous phenylalanine appearance rates reached peak values at $90 \mathrm{~min}$ after protein ingestion $\left(187 \pm 17 \mathrm{nmol} \cdot \mathrm{kg}^{-1} \cdot \mathrm{min}^{-1}\right.$; Figure $\left.2.4 \mathrm{~A}\right)$. Whole body plasma phenylalanine disappearance rates followed the rates of appearance and showed significant postprandial phenylalanine disposal (Figs. 4B-C). Conversion of L-[ring- $\left.{ }^{2} \mathrm{H}_{5}\right]-$ phenylalanine to L-[ring- ${ }^{2} \mathrm{H}_{4}$ ]-tyrosine is shown in Figure $2.4 \mathrm{D}$ and averaged $62 \pm 3$ $\eta \mathrm{mol} \cdot \mathrm{kg}^{-1} \cdot \mathrm{min}^{-1}$ during the basal state, and increased to $79 \pm 5 \mathrm{\eta mol} \cdot \mathrm{kg}^{-1} \cdot \mathrm{min}^{-1}$ during the postprandial phase $(P=0.0037)$. In this experiment, postprandial $\mathrm{L}-\left[1{ }^{13} \mathrm{C}\right]$-phenylalanine retention in the splanchnic area averaged $44.7 \pm 2.7 \%$, with thus $55.3 \pm 2.7 \%$ of the ingested $\mathrm{L}-\left[1-{ }^{13} \mathrm{C}\right]$-phenylalanine appearing in the circulation during the $5 \mathrm{~h}$ postprandial period.
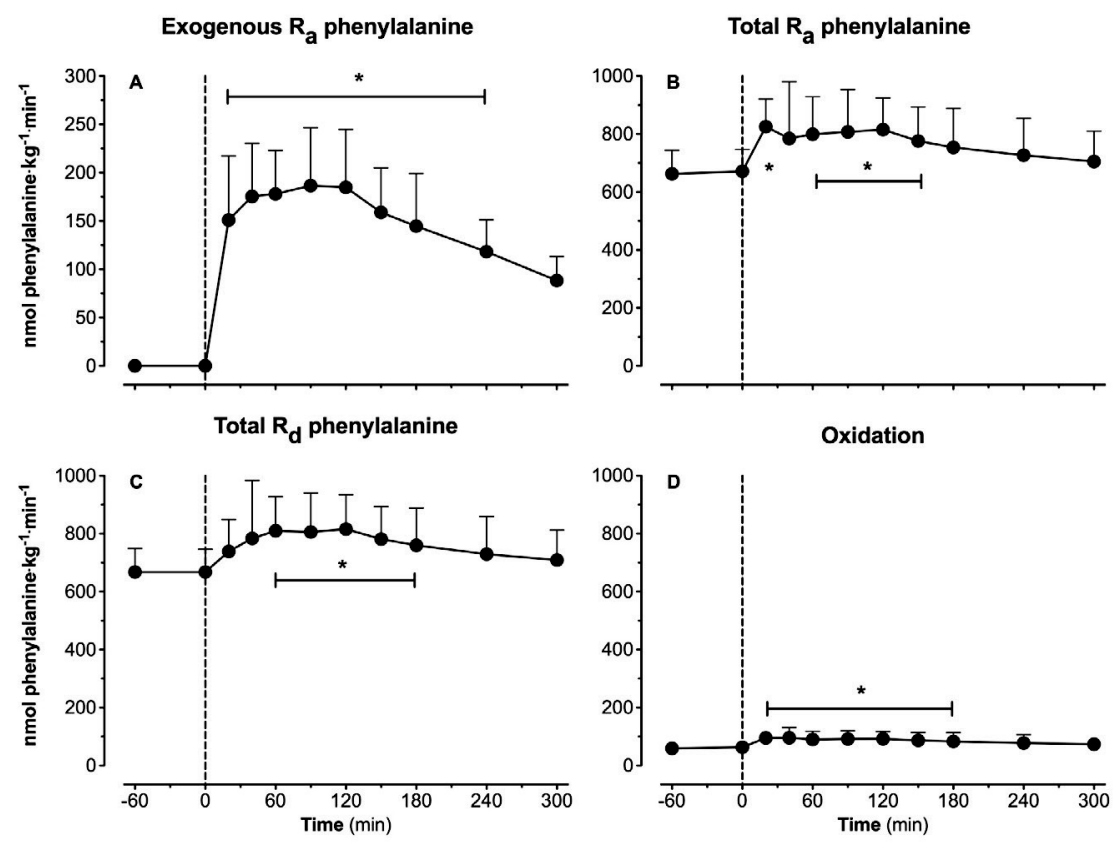

Figure 2.4 Plasma amino acids kinetics. Exogenous phenylalanine rate of appearance $\left(R_{a}\right)(A)$, total phenylalanine $R_{a}(B)$, total phenylalanine rate of disappearance $\left(R_{d}\right)(C)$ and phenylalanine-totyrosine conversion (oxidation) (D). Values represent means $\pm \mathrm{SEM}$. * Indicates a significant difference compared to baseline level $(\mathrm{t}=0 \mathrm{~min}), P<0.05$. 


\section{Whole-body amino acid kinetics}

Whole-body protein breakdown, synthesis, oxidation rates, and net balance are presented in Figure 2.5. During the basal state, breakdown rates exceeded synthesis rates, resulting in a negative net protein balance. In the postprandial state, net protein balance became positive compared to basal values due to a decline in whole-body protein breakdown rates from $619 \pm 22$ to $587 \pm 26 \mathrm{nmol}$ phenylalanine $\cdot \mathrm{kg}^{-1} \cdot \mathrm{min}^{-1}$ and an increase in whole-body protein synthesis rates from $603 \pm 22$ to $658 \pm 25 \mathrm{nmol}$ phenylalanine $\cdot \mathrm{kg}^{-1} \cdot \mathrm{min}^{-1}$.

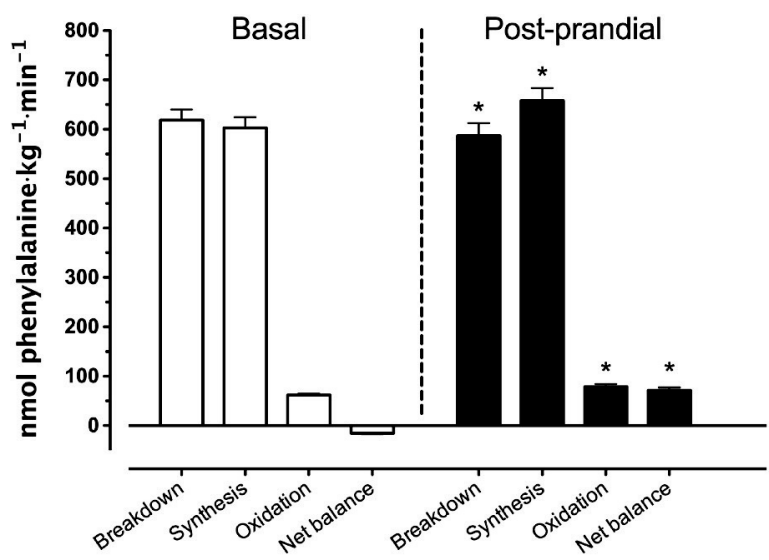

Figure 2.5 Whole body phenylalanine protein kinetics. Rates of whole body protein breakdown, synthesis, and oxidation and whole-body net protein balance (expressed as nmol phenylalanine $\cdot \mathrm{kg}^{-1} \cdot \mathrm{min}^{-1}$ ) assessed during the basal $(\mathrm{t}=-180-\mathrm{t}=0 \mathrm{~min})$ and postprandial $(\mathrm{t}=0-\mathrm{t}=300 \mathrm{~min})$ period. Values represent means \pm SEM. ${ }^{*}$ Indicates a significant difference compared to basal values, $P<0.05$

\section{3-pool kinetics}

Results of the 3-pool model calculations during de basal and postprandial period are presented in Table 2.2. Fluxes (expressed in $\mathrm{nmol} \cdot \mathrm{min}^{-1} \cdot 100 \mathrm{~mL}$ leg volume ${ }^{-1}$ ) increased during the postprandial phase, compared to basal values. Exceptions were observed for leucine with respect to shunting $\left(\mathrm{F}_{\mathrm{V}, \mathrm{A}}\right)$ and IC-availability. No significant changes were detected for phenylalanine rate of intracellular amino acid appearance from endogenous sources $\left(\mathrm{F}_{\mathrm{M}, \mathrm{O}}\right)$ and the rate of utilization of intracellular amino acids, i.e. protein synthesis and other fates (Fo,m). 
Table 2.2 Leg phenylalanine and leucine kinetics.

\begin{tabular}{|c|c|c|c|c|c|c|}
\hline \multirow[b]{2}{*}{ Flux } & \multicolumn{3}{|c|}{$\begin{array}{c}\text { Phenylalanine }(n=12) \\
\left(\mathrm{nmol} \cdot \mathrm{min}^{-1} \cdot 100 \mathrm{~mL} \text { leg volume }{ }^{-1}\right)\end{array}$} & \multicolumn{3}{|c|}{$\begin{array}{c}\text { Leucine }(n=12) \\
\left(\mathrm{nmol} \cdot \mathrm{min}^{-1} \cdot 100 \mathrm{~mL} \text { leg volume }{ }^{-1}\right)\end{array}$} \\
\hline & Basal & Postprandial & $P$ & Basal & Postprandial & $P$ \\
\hline Total leg $\mathrm{R}_{\mathrm{a}}$ & $391 \pm 27$ & $421 \pm 30$ & $<0.01$ & $1015 \pm 60$ & $1369 \pm 85$ & $<0.001$ \\
\hline Leg $R_{a}$ & $93 \pm 9$ & $72 \pm 8$ & $<0.01$ & $235 \pm 23$ & $196 \pm 22$ & $<0.01$ \\
\hline Leg $R_{d}$ & $368 \pm 26$ & $411 \pm 31$ & $<0.01$ & $987 \pm 59$ & $1409 \pm 92$ & $<0.001$ \\
\hline $\mathrm{F}_{\mathrm{M}, \mathrm{A}}$ & $302 \pm 20$ & $353 \pm 26$ & $<0.001$ & $744 \pm 47$ & $1062 \pm 78$ & $<0.001$ \\
\hline $\mathrm{F}_{\mathrm{V}, \mathrm{M}}$ & $326 \pm 21$ & $365 \pm 25$ & $<0.01$ & $773 \pm 48$ & $1023 \pm 70$ & $<0.001$ \\
\hline $\mathrm{Fv}_{\mathrm{v}, \mathrm{A}}$ & $6 \pm 8$ & $0 \pm 8$ & n.s. & $56 \pm 8$ & $102 \pm 10$ & $<0.001$ \\
\hline $\mathrm{F}_{\mathrm{M}, \mathrm{O}}$ & $161 \pm 29$ & $101 \pm 19$ & $<0.01$ & $524 \pm 65$ & $541 \pm 63$ & n.s. \\
\hline Fo,M & $137 \pm 27$ & $89 \pm 20$ & $<0.01$ & $495 \pm 65$ & $580 \pm 68$ & n.s. \\
\hline IC availability & $464 \pm 39$ & $454 \pm 34$ & n.s. & $1268 \pm 101$ & $1603 \pm 127$ & $<0.001$ \\
\hline Net balance & $-24 \pm 3$ & $-11 \pm 2$ & $<0.01$ & $-28 \pm 5$ & $40 \pm 11$ & $<0.001$ \\
\hline
\end{tabular}

Values are expressed as means \pm SEM. Phenylalanine and leucine kinetics $\left(\eta \mathrm{mol} \cdot \mathrm{min}^{-1} \cdot 100 \mathrm{~mL}\right.$ leg volume $\mathrm{m}^{-1}$ ) expressed as (total) leg $R_{a}$, leg $R_{d}$, transport into $\left(F_{M, A}\right)$ and from the muscle $\left(F_{V, M}\right)$, a-v shunting $\left(F_{V, A}\right)$, release from proteolysis $\left(\mathrm{F}_{\mathrm{M}, 0}\right)$, utilization for protein synthesis (phenylalanine) and synthesis and oxidation (leucine) $\left(F_{0, M}\right)$, and intracellular availability (IC availability) before protein ingestion (Basal) and during the entire postprandial period $(\mathrm{t}=0 \mathrm{~min}-\mathrm{t}=300 \mathrm{~min})$.

\section{Muscle free tissue and muscle enrichments}

Muscle biopsies were obtained at $\mathrm{t}=0,120$ and $300 \mathrm{~min}$. Plasma albumin obtained prior to tracer infusion was used to determine baseline L-[ring- $\left.{ }^{2} \mathrm{H}_{5}\right]$-phenylalanine enrichment to allow calculation of basal muscle protein synthesis rates using the single biopsy approach as validated previously for L-[ring- $\left.{ }^{2} \mathrm{H}_{5}\right]$-phenylalanine. ${ }^{48}$ Muscle-free and muscle protein bound tissue enrichments are summarized in Table 2.3.

Muscle protein bound L-[ring- $\left.{ }^{2} \mathrm{H}_{5}\right]$-phenylalanine enrichments significantly increased over time reaching highest levels at $\mathrm{t}=300 \mathrm{~min}(P<0.001)$. No significant increases were observed in muscle free $\mathrm{L}$-[ring- $\left.{ }^{2} \mathrm{H}_{5}\right]$-phenylalanine enrichments.

Upon ingestion of the intrinsically $\mathrm{L}-\left[1-{ }^{13} \mathrm{C}\right]$-phenylalanine (and $\mathrm{L}-\left[1-{ }^{13} \mathrm{C}\right]$-leucine) labeled protein, muscle protein bound $\mathrm{L}-\left[1-{ }^{13} \mathrm{C}\right]$-phenylalanine enrichments increased in biopsy samples collected 2 and $5 \mathrm{~h}$ after protein ingestion $(P<0.001)$. The increase in muscle free $L-\left[1-{ }^{13} \mathrm{C}\right]$-phenylalanine enrichments over time did not reach statistical significance $(P=0.104)$.

The appearance of $\mathrm{L}-\left[1-{ }^{13} \mathrm{C}\right]$-leucine in the circulation from the intravenous $\mathrm{L}-\left[1-{ }^{13} \mathrm{C}\right]-$ leucine infusion plus the digestion and amino acid absorption of intrinsically L- $\left[1-{ }^{13} \mathrm{C}\right]-$ leucine (and $\left[1{ }^{13} \mathrm{C}\right]$-phenylalanine) labeled protein led to significant increases in muscle protein bound $\mathrm{L}-\left[1-{ }^{13} \mathrm{C}\right]$-leucine enrichments at 2 and $5 \mathrm{~h}$ after protein ingestion $(P<0.001)$. The increase in muscle free $L-\left[1-{ }^{13} C\right]$-leucine enrichment over time did not reach statistical significance $(P=0.162)$. 
Table 2.3 Muscle tissue-free and muscle protein bound enrichments.

\begin{tabular}{|c|c|c|c|c|c|c|c|c|}
\hline Sample $(n=12)$ & $\begin{array}{l}\text { Stable isotope } \\
\text { tracer }\end{array}$ & $\begin{array}{l}-180 \\
\min \end{array}$ & $0 \mathrm{~min}$ & $120 \mathrm{~min}$ & $P$ & $300 \mathrm{~min}$ & $P\left({ }^{*}\right)$ & $P\left({ }^{\#}\right)$ \\
\hline \multirow[t]{3}{*}{$\begin{array}{l}\text { Muscle free } \\
\text { (MPE) }\end{array}$} & $\begin{array}{l}\mathrm{L}-\left[\text { ring }-{ }^{2} \mathrm{H}_{5}\right]- \\
\text { phenylalanine }\end{array}$ & 0 & $4.937 \pm 0.228$ & $5.136 \pm 0.285$ & 1.000 & $5.224 \pm 0.229$ & 0.854 & 1.000 \\
\hline & $\begin{array}{l}\mathrm{L}-\left[1-{ }^{13} \mathrm{C}\right]- \\
\text { phenylalanine }\end{array}$ & & 0 & $5.658 \pm 0.585^{*}$ & $<0.001$ & $3.310 \pm 0.296 *$ & $<0.001$ & 0.104 \\
\hline & $\mathrm{L}-\left[1-{ }^{13} \mathrm{C}\right]$-leucine & & 0 & $5.372 \pm 0.232 *$ & $<0.001$ & $4.831 \pm 0.220^{*}$ & $<0.001$ & 0.162 \\
\hline $\begin{array}{l}\text { Muscle protein } \\
\text { bound }\end{array}$ & $\begin{array}{l}\left.\text { L-[ring- }{ }^{2} \mathrm{H}_{5}\right]- \\
\text { phenylalanine }\end{array}$ & 0 & $0.0066 \pm 0.0005$ & $0.0127 \pm 0.0007 *$ & $<0.001$ & $\begin{array}{c}0.0213 \pm 0.0013^{*} \\
\#\end{array}$ & $<0.001$ & $<0.001$ \\
\hline \multirow[t]{2}{*}{ (MPE) } & $\begin{array}{l}\mathrm{L}-\left[1-{ }^{13} \mathrm{C}\right]- \\
\text { phenylalanine }\end{array}$ & & 0 & $0.0060 \pm 0.0017^{*}$ & $<0.01$ & $\begin{array}{c}0.0201 \pm 0.0025^{*} \\
\#\end{array}$ & $<0.001$ & $<0.001$ \\
\hline & $\mathrm{L}-\left[1-{ }^{13} \mathrm{C}\right]$-leucine & & 0 & $0.0112 \pm 0.0018 *$ & $<0.01$ & $\begin{array}{c}0.0204 \pm 0.0017^{*} \\
\#\end{array}$ & $<0.01$ & $<0.001$ \\
\hline
\end{tabular}

Muscle tissue-free and muscle protein bound enrichments at the start of the experiment $(t=-180 \mathrm{~min})$, the end of the basal period $(t=0 \mathrm{~min})$, the early $(t=120 \mathrm{~min})$ and the late $(t=300 \mathrm{~min})$ stages of the postprandial phase (MPE). Muscle free and muscle protein bound $\mathrm{L}$-[ring- $\left.{ }^{2} \mathrm{H}_{5}\right]$-phenylalanine enrichments at $\mathrm{t}=-180$ min were assessed based upon plasma albumin as an alternative of a baseline biopsy sample as described previously. ${ }^{48}$. Values are expressed as means \pm SEM. ${ }^{*}$ : Statistically different from basal ( $\mathrm{t}=0 \mathrm{~min}$ ). \# : Statistically different from the early stage of the postprandial state $(t=120 \mathrm{~min})$. Data were analyzed by repeated measures ANOVA.

\section{Mixed muscle FSR}

L-[ring- ${ }^{2} \mathrm{H}_{5}$ ]-phenylalanine based mixed muscle protein fractional synthesis rates, and L$\left[1-{ }^{13} \mathrm{C}\right]$-phenylalanine muscle tissue enrichments (MPE) are presented in Figure 2.6. Mixed-muscle protein synthesis rates, with the weighed mean plasma L-[ring- $\left.{ }^{2} \mathrm{H}_{5}\right]-$ phenylalanine enrichment as precursor, averaged $0.029 \pm 0.002 \% \cdot h^{-1}$ in the basal, overnight fasted state. During the early digestion phase $(0-2 \mathrm{~h})$, and over the entire postprandial phase $(0-5 \mathrm{~h})$, mixed muscle protein synthesis rates increased to $0.047 \pm 0.003$ and $0.044 \pm 0.004 \% \cdot h^{-1}$, respectively (both $P<0.01$ compared to the basal state). The mean \pm SEM $(95 \% \mathrm{Cl})$ of the differences between basal and postprandial muscle protein synthesis rates averaged $0.0161 \pm 0.0031(0.0110-0.0226)$ with an effect size of 1.79 .

Postprandial muscle protein synthesis rates were also calculated based upon the $\mathrm{L}-\left[1-{ }^{13} \mathrm{C}\right]$-leucine tracer resulting in muscle protein synthesis rates averaging $0.063 \pm 0.014$ and $0.058 \pm 0.006 \% \cdot h^{-1}$ during the early $(0-2 h)$ and the complete $5 \mathrm{~h}$ postprandial period. Fractional synthesis rates were calculated with the weighed average plasma L-[ring- $\left.{ }^{2} \mathrm{H}_{5}\right]$-phenylalanine or $\mathrm{L}-\left[1-{ }^{13} \mathrm{C}\right]$-leucine enrichments being used as precursor pool. Muscle protein synthesis rates calculated based upon the muscle free precursor pool(s) resulted in similar findings (data not shown). Mixed muscle protein 
$\mathrm{L}-\left[1-{ }^{13} \mathrm{C}\right]$-phenylalanine enrichments increased from 0 to $0.0060 \pm 0.0017$ and $0.0201 \pm 0.0025 \mathrm{MPE}$ at 2 and $5 \mathrm{~h}$ after protein ingestion, respectively, showing substantial incorporation of dietary protein derived $L-\left[1-{ }^{13} \mathrm{C}\right]$-phenylalanine into de novo muscle protein $(P<0.001)$.

\section{L-[ring- $\left.{ }^{2} \mathrm{H}_{5}\right]$-phenylalanine}

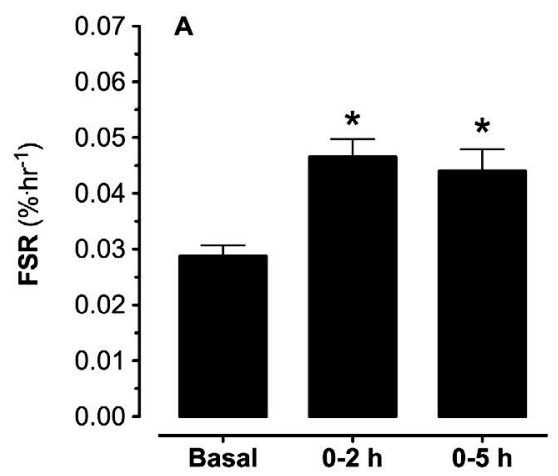

L-[1-13 C]-phenylalanine

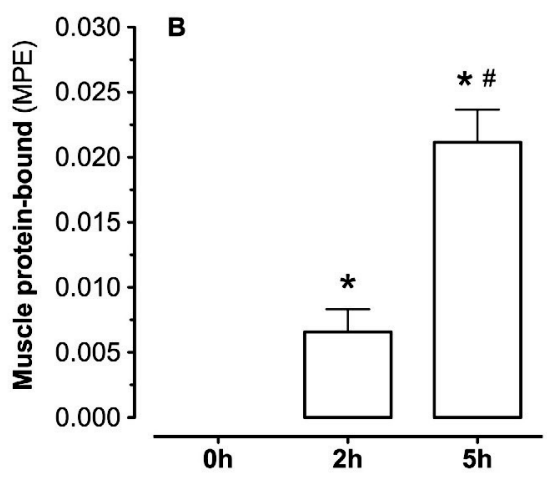

Figure 2.6 Mixed muscle protein synthesis and muscle tissue enrichments.

Muscle protein synthesis rates (FSR) based on plasma L-[ring- $\left.{ }^{2} \mathrm{H}_{5}\right]$-phenylalanine (A), and L-[1${ }^{13} \mathrm{C}$ ]-phenylalanine (B) protein bound muscle protein enrichments (MPE). Values represent means \pm SEM. ${ }^{*}$ Indicates a significant difference compared to basal values, $P<0.05 .{ }^{\#}$ Indicates a significant difference compared to basal values, $P<0.05$.

\section{Discussion}

The present study demonstrates that ingestion of a single meal-like amount of protein allows $\sim 55 \%$ of these protein-derived amino acids to become available in the systemic circulation during a $5 \mathrm{~h}$ postprandial period. The protein-derived amino acids are taken up in skeletal muscle tissue, improving leg and whole-body protein balance, and increasing muscle protein synthesis rates beyond basal, post-absorptive values. Following ingestion of $20 \mathrm{~g}$ casein, $11 \%$ of the dietary protein derived amino acids $(2.2 \pm 0.3 \mathrm{~g})$ were incorporated in de novo muscle protein within the $5 \mathrm{~h}$ postprandial period.

In the present study we combined ingestion of specifically produced intrinsically L-[1${ }^{13} \mathrm{C}$ ]-phenylalanine labeled protein with continuous intravenous infusion of L-[ring- $\left.{ }^{2} \mathrm{H}_{5}\right]$ phenylalanine to allow assessment of dietary protein digestion and absorption kinetics in vivo in humans. Ingestion of $20 \mathrm{~g}$ casein was followed by proper digestion and amino acid absorption, as indicated by the rapid increase in both plasma phenylalanine, and 
total essential amino acid concentrations (Figure 2.2) as well as plasma L-[1- $\left.{ }^{13} \mathrm{C}\right]-$ phenylalanine enrichments (Figure 2.3). Following the ingestion of $20 \mathrm{~g}$ protein, $25 \pm 2 \%$ of the dietary protein derived phenylalanine had been released into the circulation within the first $2 \mathrm{~h}$ of the postprandial phase, followed by another $30 \pm 2 \%$ during the subsequent $3 \mathrm{~h}$. These findings are in line with previous observations using intrinsically

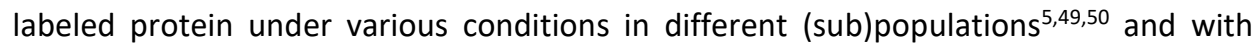
earlier estimations of splanchnic amino acid extraction during continuous oral administration of free crystalline phenylalanine in healthy, older men. ${ }^{51}$ The present data show that $55 \pm 3 \%$ of dietary protein derived amino acids are being released in the circulation during a $5 \mathrm{~h}$ postprandial period, making these amino acids available as precursors for de novo muscle protein synthesis. The other dietary protein derived amino acids ( $\sim 5 \%$ ) are retained in the splanchnic area, providing precursors for gut and liver protein synthesis to help sustain their functional mass. ${ }^{52}$

The dietary protein derived amino acids appearing in the circulation were effectively taken-up by skeletal muscle tissue. Using an AV model, we measured amino acid inflow and outflow from the leg, allowing us to determine net amino acid uptake over the leg (Figures 2.2B, D, F). Protein ingestion did not result in a measurable increase in leg blood flow, as has been reported previously following amino acid $^{51,53}$ or protein ${ }^{54-56}$ administration. Therefore, differences in amino acid uptake over the leg were fully attributed to the differences between arterial and venous amino acid concentrations (Figures 2.2A, C, E). Leg protein balance was negative in the basal, post-absorptive state and improved substantially following protein ingestion. Phenylalanine net balance improved following protein ingestion but remained slightly negative, which is commonly observed and attributed to the release of phenylalanine from subdermal and intramuscular fat depots. ${ }^{57}$ In agreement, a positive net amino acid balance was observed following protein ingestion when arteriovenous differences in leucine or the sum of all essential amino acid concentrations were assessed (Figure 2.2). The essential amino acid net balance increased from $-204 \pm 87 \mu \mathrm{mol} \cdot \mathrm{min}^{-1} \cdot 100 \mathrm{~mL}$ leg volume ${ }^{-1}$ in the basal post-absorptive state to $66 \pm 77 \mu \mathrm{mol} \cdot \mathrm{min}^{-1} \cdot 100 \mathrm{~mL}$ leg volume ${ }^{-1}$ following protein ingestion.

A more positive protein balance was not only observed in the leg but also on a wholebody level (Figure 2.5) The postprandial increase in plasma amino acid availability stimulated whole body protein synthesis and oxidation rates, and inhibited proteolysis, resulting in a positive whole-body protein balance. However, whole-body protein kinetics do not necessarily reflect changes in muscle protein synthesis or breakdown rates in skeletal muscle tissue as they do not differentiate between tissues and do not provide information on the metabolic fate of the amino acids taken up in these tissues. ${ }^{58}$ To provide more insight in the impact of protein ingestion on postprandial amino acid handling in skeletal muscle tissue and to assess not only amino acid uptake and release from the leg, but also amino acid uptake and release from skeletal muscle tissue, we also applied a three-pool model. ${ }^{23}$ The postprandial rise in plasma amino acid 
availability stimulated amino acid uptake in skeletal muscle tissue thereby increasing intramyocellular amino acid availability (Table 2.3). The latter was accompanied by a reduction in muscle protein breakdown, $\mathrm{F}_{\mathrm{m}, \mathrm{o}}$, (for phenylalanine but not for leucine) but without measurable increases in muscle protein synthesis, $F_{o, m}$, in the postprandial compared with the post-absorptive state (for both phenylalanine and leucine). Of course, the two- and three-pool models have their limitations, with methodological complications associated with assessing skeletal muscle blood flow (or tissue perfusion). Nonetheless, these data provide us more insight in the greater extraction of amino acids over the leg in the postprandial when compared with post-absorptive state.

The three-pool model was used to provide us with estimations of intramyocellular trafficking of the amino acids taken up in the leg, ${ }^{23}$ but this model does not provide a direct evaluation of the impact of protein ingestion of muscle protein synthesis rates or the metabolic fate of the ingested protein derived amino acids towards de novo muscle protein accretion. Therefore, we measured both muscle free and muscle protein bound $\mathrm{L}-\left[\right.$ ring $\left.-{ }^{2} \mathrm{H}_{5}\right]$-phenylalanine, $\mathrm{L}-\left[1-{ }^{13} \mathrm{C}\right]$-leucine and $\mathrm{L}-\left[1-{ }^{13} \mathrm{C}\right]$-phenylalanine enrichments in muscle samples collected prior to protein ingestion and 2 and $5 \mathrm{~h}$ into the postprandial phase (Table 2.3). By also measuring plasma albumin protein bound [ring- ${ }^{2} \mathrm{H}_{5}$ ]phenylalanine enrichments from a blood sample collected prior to [ring- ${ }^{2} \mathrm{H}_{5}$ ]phenylalanine infusion, we were able to assess basal muscle protein synthesis rates (between $\mathrm{t}=-180-0 \mathrm{~min}$ ) using the single biopsy methodology that has been validated previously for FSR measurements based on prolonged [ring- ${ }^{2} \mathrm{H}_{5}$ ]-phenylalanine infusion $[48,59,60]$. Ingestion of $20 \mathrm{~g}$ protein increased muscle protein synthesis rates by $58 \pm 11 \%$ from $0.029 \pm 0.002 \% \cdot h^{-1}$ in the post-absorptive state to $0.047 \pm 0.003 \% \cdot h^{-1}$ and $0.044 \pm 0.004 \% \cdot h^{-1}$ during the early $(2 \mathrm{~h})$ and the entire $(5 \mathrm{~h})$ postprandial phase $\left(P<0.01\right.$ : Figure 2.6A). Postprandial muscle protein synthesis rates based upon L- $\left[1-{ }^{13} \mathrm{C}\right]-$ leucine infusion averaged $0.063 \pm 0.014 \% \cdot h^{-1}$ and $0.058 \pm 0.006 \% \cdot h^{-1}$ calculated during the early and over the entire $5 \mathrm{~h}$ postprandial phase, respectively.

In addition to the assessment of basal and postprandial muscle protein synthesis following primed continuous infusion of $\mathrm{L}$-[ring- $\left.{ }^{2} \mathrm{H}_{5}\right]$-phenylalanine or primed continuous infusion of $\mathrm{L}-\left[1{ }^{13} \mathrm{C}\right]$-leucine combined with the ingestion of intrinsically $\mathrm{L}-\left[1-{ }^{13} \mathrm{C}\right]$-leucine labeled protein, we also evaluated the metabolic fate of the ingested protein by measuring the incorporation of dietary protein derived $\mathrm{L}-\left[1-{ }^{13} \mathrm{C}\right]-$ phenylalanine into the muscle protein pool. Based upon the pioneering work of Beaufrere and Boirie, ${ }^{43,46,61,62}$ we have further developed the production of intrinsically $\mathrm{L}-\left[1-{ }^{13} \mathrm{C}\right]$-phenylalanine labeled milk protein with phenylalanine enrichment levels exceeding 30-35 MPE by infusing large amounts of $L-\left[1-{ }^{13} \mathrm{C}\right]$-phenylalanine in lactating Holstein cows. ${ }^{21,32,63}$ Application of this protein in human nutrition studies does not only allow us to assess in vivo dietary protein digestion and absorption kinetics but also to directly measure the incorporation of dietary protein derived $\mathrm{L}-\left[1-{ }^{13} \mathrm{C}\right]$-phenylalanine into muscle protein in vivo in human. Ingestion of the intrinsically labeled protein 
resulted in large increases in muscle free as well as muscle protein bound L-[1- $\left.{ }^{13} \mathrm{C}\right]-$ phenylalanine enrichments (Table 2.3). The latter proving the uptake and subsequent use of the dietary protein derived amino acids for de novo muscle protein synthesis during the early and late postprandial stage. The use of intrinsically L- $\left[1-{ }^{13} \mathrm{C}\right]-$ phenylalanine labeled protein with an enrichment level exceeding 35 MPE allows us to assess the metabolic fate of the ingested dietary protein bound phenylalanine by measuring the increase in skeletal muscle protein bound $\mathrm{L}-\left[1-{ }^{13} \mathrm{C}\right]$-phenylalanine enrichments 2 and 5 hours after protein ingestion (Figure 2.6B). These values do not represent fractional muscle protein synthesis rates but provide insight in the postprandial incorporation of dietary protein derived amino acids into de novo muscle protein. The increase in $\mathrm{L}-\left[1-{ }^{13} \mathrm{C}\right]$-phenylalanine enrichments during the postprandial period correlated well with the postprandial FSR values calculated for both L-[ring- $\left.{ }^{2} \mathrm{H}_{5}\right]$ phenylalanine $\left(R^{2}=0.38 ; P<0.06\right)$ and $L-\left[1-{ }^{13} C\right]$-leucine $\left(R^{2}=0.37 ; P<0.07\right)$. Assuming that all appendicular muscle mass has obtained a similar $L-\left[1-{ }^{13} \mathrm{C}\right]$-phenylalanine enrichment as observed in the $M$. vastus lateralis biopsy sample of each individual, a total of $0.040 \pm 0.006 \mathrm{~g} \mathrm{~L}-\left[1-{ }^{13} \mathrm{C}\right]$-phenylalanine has been incorporated in the appendicular skeletal muscle mass throughout the $5 \mathrm{~h}$ postprandial period. This represents $11.0 \pm 1.7 \%$ of the $\mathrm{L}-\left[1-{ }^{13} \mathrm{C}\right]$-phenylalanine that was provided within the $20 \mathrm{~g}$ intrinsically $\mathrm{L}-\left[1-{ }^{13} \mathrm{C}\right]$-phenylalanine labeled casein. Consequently, we confirm our hypothesis that following the ingestion of a single meal-like bolus of protein as much as $\sim 11 \%$ of the protein derived amino acids $(2.2 \pm 0.3 \mathrm{~g})$ are directly taken up in skeletal muscle tissue and used as amino acid precursors to support de novo muscle protein synthesis during a 5 postprandial period.

The present study provides a complete and comprehensive insight in the metabolic fate of dietary protein derived amino acids following the ingestion of a single meal-like bolus of protein. Though it has been well established that protein intake increases muscle protein synthesis rates, ${ }^{54-56}$ these data show that a substantial part of the ingested protein derived amino acids are taken up and directly used to support the postprandial rise in muscle protein synthesis rate following ingestion of a single bolus of protein. The dietary protein derived amino acids not only present themselves as strong signaling molecules, but also act as direct precursors for de novo muscle protein synthesis. In short, ingestion of a single meal-like amount of protein allows $\sim 55 \%$ of the protein derived amino acids to become available in the circulation, thereby improving whole-body as well as leg muscle protein balance. Approximately $20 \%$ of the protein derived plasma amino acids will be taken up in skeletal muscle tissue during a $5 \mathrm{~h}$ postprandial period, thereby stimulating muscle protein synthesis rates and providing precursors for de novo muscle protein. In conclusion, you are what you just ate. 


\section{References}

1. Volpi E, Sheffield-Moore M, Rasmussen BB, Wolfe RR. Basal muscle amino acid kinetics and protein synthesis in healthy young and older men. JAMA 2001;286:1206-12.

2. Baños G, Daniel P, Moorhouse S, Pratt O. The movement of amino acids between blood and skeletal muscle in the rat. The Journal of physiology 1973;235:459-75.

3. Silk DB, Grimble GK, Rees RG. Protein digestion and amino acid and peptide absorption. Proc Nutr Soc 1985;44:63-72.

4. Rodriguez P, Setten M, Maskin L, Bonelli I, Vidomlansky S, et al. Muscle weakness in septic patients requiring mechanical ventilation: protective effect of transcutaneous neuromuscular electrical stimulation. J Crit Care 2012;27:3190-8.

5. Pennings B, Koopman R, Beelen M, Senden JM, Saris WH, et al. Exercising before protein intake allows for greater use of dietary protein-derived amino acids for de novo muscle protein synthesis in both young and elderly men. Am J Clin Nutr 2011;93:322-31.

6. Rasmussen BB, Fujita S, Wolfe RR, Mittendorfer B, Roy M, et al. Insulin resistance of muscle protein metabolism in aging. FASEB J 2006;20:768-9.

7. Zhang H, Dellsperger K, Zhang $C$. The link between metabolic abnormalities and endothelial dysfunction in type 2 diabetes: an update. Basic Res Cardiol 2012;107:237.

8. English K, Paddon-Jones D. Protecting muscle mass and function in older adults during bed rest. Current opinion in clinical nutrition and metabolic care 2010;13:34-9.

9. Cuthbertson D, Smith K, Babraj J, Leese G, Waddell T, et al. Anabolic signaling deficits underlie amino acid resistance of wasting, aging muscle. FASEB J 2005;19:422-4.

10. Fry CS, Drummond MJ, Glynn EL, Dickinson JM, Gundermann DM, et al. (2011) Aging impairs contraction-induced human skeletal muscle mTORC1 signaling and protein synthesis. Skelet Muscle 2011;1:11.

11. Volpi E, Ferrando A, Yeckel C, Tipton K, Wolfe R. Exogenous amino acids stimulate net muscle protein synthesis in the elderly. J Clin Invest 1998;101:2000-7.

12. Breen L, Phillips SM. Skeletal muscle protein metabolism in the elderly: Interventions to counteract the 'anabolic resistance' of ageing. Nutr Metab (Lond) 2011;8:68.

13. Koopman R, Walrand S, Beelen M, Gijsen A, Kies A, et al. Dietary protein digestion and absorption rates and the subsequent postprandial muscle protein synthetic response do not differ between young and elderly men. The Journal of nutrition 2009;139:1707-13.

14. Gorissen SH, Burd NA, Hamer HM, Gijsen AP, Groen BB, et al. Carbohydrate coingestion delays dietary protein digestion and absorption but does not modulate postprandial muscle protein accretion. J Clin Endocrinol Metab 2014;99:2250-8.

15. Groen BB, Res PT, Pennings B, Hertle E, Senden JM, et al. Intragastric protein administration stimulates overnight muscle protein synthesis in elderly men. Am J Physiol Endocrinol Metab. 2012;302:E52-60.

16. Schnitzer JE. Transport functions of the glycocalyx, specific proteins, and caveolae in endothelium. In: Bassingthwaighte J, Goresky CA, Linehan JH, editors. Whole organ approaches to cellular metabolism. New York: Springer. 1998:31-69.

17. Groen BB, Hamer HM, Snijders T, van Kranenburg J, Frijns D, et al. (2014) Skeletal muscle capillary density and microvascular function are compromised with aging and type 2 diabetes. J Appl Physiol (1985). 2014;116:998-1005.

18. Pennings B, Groen BB, de Lange A, Gijsen AP, Zorenc AH, et al. (2012) Amino acid absorption and subsequent muscle protein accretion following graded intakes of whey protein in elderly men. Am J Physiol Endocrinol Metab. 2012;302:E992-9.

19. Pennings B, Groen BB, van Dijk JW, de Lange A, Kiskini A, et al. Minced beef is more rapidly digested and absorbed than beef steak, resulting in greater postprandial protein retention in older men. Am J Clin Nutr 2013;98:121-8.

20. Res PT, Groen B, Pennings B, Beelen M, Wallis GA, et al. Protein ingestion before sleep improves postexercise overnight recovery. Med Sci Sports Exerc. 2012;44:1560-9.

21. van Loon L, Boirie Y, Gijsen AP, Fauquant J, de Roos AL, et al. The production of intrinsically labeled milk protein provides a functional tool for human nutrition research. J Dairy Sci 2009;92:4812-4822. 
22. Wall BT, Hamer HM, de Lange A, Kiskini A, Groen BB, et al. (2012) Leucine co-ingestion improves postprandial muscle protein accretion in elderly men. Clin Nutr. 2013;32:412-9.

23. Biolo G, Fleming RY, Maggi SP, Wolfe RR. Transmembrane transport and intracellular kinetics of amino acids in human skeletal muscle. Am J Physiol 1995;268:E75-84.

24. Skelton DA, Greig CA, Davies JM, Young A. (1994) Strength, power and related functional ability of healthy people aged 65-89 years. Age Ageing 1994;23:371-7.

25. Volpi E, Ferrando AA, Yeckel CW, Tipton KD, Wolfe RR. Exogenous amino acids stimulate net muscle protein synthesis in the elderly. J Clin Invest 1998;101:2000-7.

26. Felig P (1975) Amino acid metabolism in man. Annu Rev Biochem 44: 933-955.

27. Wagenmakers AJ. Tracers to investigate protein and amino acid metabolism in human subjects. Proc Nutr Soc 1999;58: 987-1000.

28. Pennings B, Groen B, de Lange A, Gijsen A, Zorenc A, et al. Amino acid absorption and subsequent muscle protein accretion following graded intakes of whey protein in elderly men. Am J Physiol Endocrinol Metab 2012;302:9.

29. Reitelseder S, Agergaard J, Doessing S, Helmark IC, Lund P, et al. Whey and casein labeled with L-[113C]leucine and muscle protein synthesis: effect of resistance exercise and protein ingestion. Am J Physiol Endocrinol Metab. 2011;300:E231-42.

30. Koopman R, Crombach N, Gijsen AP, Walrand S, Fauquant J, et al. Ingestion of a protein hydrolysate is accompanied by an accelerated in vivo digestion and absorption rate when compared with its intact protein. Am J Clin Nutr 2009;90:106-15.

31. Koopman R, Walrand S, Beelen M, Gijsen AP, Kies AK, et al. (2009) Dietary protein digestion and absorption rates and the subsequent postprandial muscle protein synthetic response do not differ between young and elderly men. J Nutr 2009;139:1707-13.

32. Burd NA, Hamer HM, Pennings B, Pellikaan WF, Senden JM, et al. Substantial Differences between Organ and Muscle Specific Tracer Incorporation Rates in a Lactating Dairy Cow. PLoS One 2013;8: e68109.

33. Burd NA, Cermak NM, Kouw IW, Gorissen SH, Gijsen AP, et al. The use of doubly labeled milk protein to measure postprandial muscle protein synthesis rates in vivo in humans. J Appl Physiol (1985) 2014;117:1363-70.

34. ADA. Diagnosis and classification of diabetes mellitus. Diabetes Care 2006;29 Suppl 1:S43-8.

35. Mari A, Pacini G, Murphy E, Ludvik B, Nolan JJ. A model-based method for assessing insulin sensitivity from the oral glucose tolerance test. Diabetes Care 2001;24:539-548.

36. Jones PR, Pearson J. Anthropometric determination of leg fat and muscle plus bone volumes in young male and female adults. J Physiol 1969;204: 63P-6P.

37. van Hall G, Gonzalez-Alonso J, Sacchetti M, Saltin B. Skeletal muscle substrate metabolism during exercise: methodological considerations. Proc Nutr Soc 1999;58:899-912.

38. Landsman ML, Kwant G, Mook GA, Zijlstra WG. Light-absorbing properties, stability, and spectral stabilization of indocyanine green. Journal of applied physiology 1976;40:575-83.

39. Bergstrom J. Percutaneous needle biopsy of skeletal muscle in physiological and clinical research. Scand J Clin Lab Invest 1975;35:609-16.

40. Waterval WA, Scheijen JL, Ortmans-Ploemen MM, Habets-van der Poel CD, Bierau J. Quantitative UPLCMS/MS analysis of underivatised amino acids in body fluids is a reliable tool for the diagnosis and follow-up of patients with inborn errors of metabolism. Clin Chim Acta 2009;407:36-42.

41. Biolo G, Tessari P, Inchiostro S, Bruttomesso D, Fongher C, et al. Leucine and phenylalanine kinetics during mixed meal ingestion: a multiple tracer approach. Am J Physiol 1992;262:E455-63.

42. Wolfe RR. Tracers in metabolic research: radioisotope and stable isotope/mass spectrometry methods. Lab Res Methods Biol Med 1984;9:1-287.

43. Boirie Y, Gachon P, Corny S, Fauquant J, Maubois JL, et al. Acute postprandial changes in leucine metabolism as assessed with an intrinsically labeled milk protein. Am J Physiol 1996;271:E1083-91.

44. Wolfe RR. Radioactive and stable isotope tracers in biomedicine: Principles and practice of kinetic analysis New York: Wiley-Liss. 1992:480

45. Fujita S, Rasmussen BB, Cadenas JG, Grady JJ, Volpi E. Effect of insulin on human skeletal muscle protein synthesis is modulated by insulin-induced changes in muscle blood flow and amino acid availability. Am J Physiol Endocrinol Metab 2006;291:E745-54. 
46. Boirie $\mathrm{Y}$, Fauquant J, Rulquin H, Maubois JL, Beaufrere B. Production of large amounts of [13C]leucineenriched milk proteins by lactating cows. J Nutr 1995;125:92-8.

47. Jorfeldt $L$, Wahren J. Leg blood flow during exercise in man. Clin Sci 41: 459-73.

48. Burd NA, Pennings B, Groen BB, Gijsen AP, Senden JM, et al. The single biopsy approach is reliable for the measurement of muscle protein synthesis rates in vivo in older men. Journal of applied physiology 2012;113:896-902.

49. Matthews DE. An overview of phenylalanine and tyrosine kinetics in humans. J Nutr 2007;137: 1549S-55S.

50. Koopman R, Beelen M, Stellingwerff T, Pennings B, Saris WH, et al. Coingestion of carbohydrate with protein does not further augment postexercise muscle protein synthesis. Am J Physiol Endocrinol Metab 2007;293:E833-42.

51. Volpi E, Mittendorfer B, Wolf SE, Wolfe RR. Oral amino acids stimulate muscle protein anabolism in the elderly despite higher first-pass splanchnic extraction. Am J Physiol 1999;277:E513-20.

52. Deutz NE, Bruins MJ, Soeters PB. Infusion of soy and casein protein meals affects interorgan amino acid metabolism and urea kinetics differently in pigs. J Nutr 1998;128:2435-45.

53. Paddon-Jones D, Sheffield-Moore M, Zhang XJ, Volpi E, Wolf SE, et al. Amino acid ingestion improves muscle protein synthesis in the young and elderly. Am J Physiol Endocrinol Metab 2004;286: E321-328.

54. Koopman R, Wagenmakers A, Manders R, Zorenc A, Senden J, et al. Combined ingestion of protein and free leucine with carbohydrate increases postexercise muscle protein synthesis in vivo in male subjects. American journal of physiology Endocrinology and metabolism 2005;288:53.

55. Dangin $M$, Boirie $Y$, Guillet $C$, Beaufrere B. Influence of the protein digestion rate on protein turnover in young and elderly subjects. J Nutr 2002;132:3228S-33S.

56. Pennings B, Boirie Y, Senden JM, Gijsen AP, Kuipers H, et al. (2011) Whey protein stimulates postprandial muscle protein accretion more effectively than do casein and casein hydrolysate in older men. Am J Clin Nutr 2011;93:997-1005.

57. Coppack SW, Persson M, Miles JM. Phenylalanine kinetics in human adipose tissue. J Clin Invest 1996;98:692-7.

58. Koopman R, Wagenmakers AJ, Manders RJ, Zorenc AH, Senden JM, et al. Combined ingestion of protein and free leucine with carbohydrate increases postexercise muscle protein synthesis in vivo in male subjects. Am J Physiol Endocrinol Metab 2005;288:E645-53.

59. Heys SD, McNurlan MA, Park KG, Milne E, Garlick PJ. Baseline measurements for stable isotope studies: an alternative to biopsy. Biomed Environ Mass Spectrom 1990;19:176-8.

60. Smith GI, Villareal DT, Lambert CP, Reeds DN, Mohammed BS, et al. Timing of the initial muscle biopsy does not affect the measured muscle protein fractional synthesis rate during basal, postabsorptive conditions. J Appl Physiol 2010;108 36368.

61. Boirie $\mathrm{Y}$, Dangin M, Gachon P, Vasson MP, Maubois JL, et al. Slow and fast dietary proteins differently modulate postprandial protein accretion. Proc Natl Acad Sci U S A 1997;94:14930-5.

62. Boirie $Y$, Gachon P, Beaufrere B. Splanchnic and whole-body leucine kinetics in young and elderly men. Am J Clin Nutr 1997;65:489-95.

63. Pennings B, Pellikaan WF, Senden JM, van Vuuren AM, Sikkema J, et al. The production of intrinsically labeled milk and meat protein is feasible and provides functional tools for human nutrition research. J Dairy Sci 2011;94:4366-73. 


\section{Chapter 3}

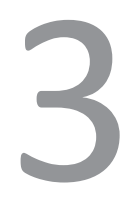

Increasing insulin availability does not augment postprandial muscle protein synthesis rates in healthy young and older men

Bart B.L. Groen, Astrid M. Horstman, Henrike M. Hamer, Michiel de Haan, Janneau van Kranenburg, Jörgen Bierau, Martijn Poeze, Will K.W.H. Wodzig, Blake B. Rasmussen, Luc J.C. van Loon

Accepted 


\section{Abstract}

\section{Context}

Skeletal muscle protein synthesis is highly responsive to food intake. It has been suggested that the postprandial increase in circulating insulin modulates the muscle protein synthetic response to feeding.

\section{Objective}

To investigate whether a greater postprandial rise in circulating insulin level increases amino acid uptake in muscle and augments postprandial muscle protein synthesis rates.

\section{Participants and design}

48 healthy young (age $22 \pm 1 \mathrm{y} ; \mathrm{BMI} 22.0 \pm 0.3 \mathrm{~kg} \cdot \mathrm{m}-2$ ) and older males (age $68 \pm 1 \mathrm{y} ; \mathrm{BMI} 26.3 \pm 0.4$ $\mathrm{kg} \cdot \mathrm{m}-2)$ ingested $20 \mathrm{~g}$ intrinsically L-[1-13C]-leucine and L-[1-13C]-phenylalanine labeled casein protein with or without local insulin infusion. Primed continuous infusions of L-[1-13C]-leucine and L-[ring-2H5]-phenylalanine were applied, with arterial and venous blood samples and muscle biopsies being collected during a $5 \mathrm{~h}$ postprandial period.

\section{Results}

Insulin administration did not increase overall leg blood flow $(P=0.509)$, but increased amino acid uptake over the leg in both young and older subjects $(P=0.003)$. The greater amino acid uptake over the leg did not further increase postprandial muscle protein synthesis rates $(0.050 \pm 0.006$ and $0.037 \pm 0.004 \% \cdot h-1$ versus $0.044 \pm 0.004$ and $0.037 \pm 0.002 \% \cdot h-1$, in the insulin-stimulated versus control condition in the young and older groups, respectively; $\mathrm{P}=0.804$ ) and did not affect postprandial deposition of dietary protein-derived amino acids in de novo muscle protein $(\mathrm{P}=0.872)$.

\section{Conclusion}

Greater postprandial plasma insulin availability stimulates amino acid uptake over the leg but does not further augment postprandial muscle protein synthesis rates or stimulate the post-prandial deposition of protein derived amino acids into de novo muscle protein in healthy young and older men. 


\section{Introduction}

Skeletal muscle protein turnover is highly responsive to food intake. ${ }^{1,2}$ The skeletal muscle protein synthetic and anti-proteolytic response to food ingestion are regulated on multiple levels, ranging from dietary protein digestion and amino acid absorption, postprandial insulin release and subsequent microvascular perfusion, amino acid delivery and uptake in muscle, intramyocellular anabolic signaling and finally myofibrillar protein synthesis and breakdown. ${ }^{2-9}$ It has been proven difficult to define the impact of each of these variables on the anabolic response to protein feeding in an in vivo human setting.

Many of the parameters that define postprandial protein handling are modulated by the postprandial rise in circulating insulin. Insulin stimulates muscle protein synthesis directly by activating the translational machinery. ${ }^{10,11}$ Furthermore, insulin may modulate postprandial precursor availability by stimulating nutritive blood flow to skeletal muscle tissue and enhancing amino acid uptake. ${ }^{4,12,13}$ However, the proposed stimulating role of insulin on postprandial muscle protein synthesis has been subject of intense debate. ${ }^{14,15}$ It remains unclear whether circulating insulin levels are merely permissive or rather modulatory to facilitate the postprandial increase in muscle protein synthesis. Whereas hyperinsulinemia has been shown to increase muscle protein synthesis rates under conditions of hyperaminoacidemia, others have reported that circulating insulin levels below $30 \mathrm{mU} \cdot \mathrm{L}^{-1}$ are sufficient to maximize muscle protein synthesis rates during continuous intravenous amino acid infusion. ${ }^{16-25}$ We hypothesized that increasing postprandial insulin availability stimulates postprandial amino acid uptake and increases subsequent muscle protein synthesis rates, allowing more of the dietary protein derived amino acids to be used for de novo muscle protein synthesis.

The postprandial muscle protein synthetic response to amino acid or protein ingestion is blunted in the older population and is now referred to as 'anabolic resistance of aging'. ${ }^{\prime}, 26,27$ Despite the fact that anabolic resistance represents a key factor in the etiology of sarcopenia, little is known about the mechanisms responsible for the blunted muscle protein synthetic response to feeding in an older population. ${ }^{28-33}$ However, a reduced sensitivity to insulin has been proposed to impair amino acid uptake and attenuate the postprandial rise in myofibrillar protein synthesis in older adults. ${ }^{26,34} \mathrm{We}$ hypothesized that increasing postprandial insulin availability augments the postprandial muscle protein synthetic response to protein ingestion to a greater extend in older compared with younger adults, resulting in more of the dietary protein derived amino acids being used for de novo muscle protein synthesis.

In the present study we assess to what extent a physiological increase in postprandial insulin availability stimulates postprandial amino acid uptake, increases muscle protein synthesis, and augments the use of protein derived amino acids for de novo muscle protein synthesis in young and older males. This study provides a multi-level assessment of the impact of insulin availability on postprandial protein handling following ingestion of a single meal-like amount of protein in young and older males. 


\section{Methods}

\section{Subjects}

Twenty-four healthy young (age: $22 \pm 1 \mathrm{y} ; \mathrm{BMI}: 22.0 \pm 0.3 \mathrm{~kg} \cdot \mathrm{m}^{-2}$ ) and twenty-four healthy older (age: $68 \pm 1 \mathrm{y} ; \mathrm{BMI}: 26.3 \pm 0.4 \mathrm{~kg} \cdot \mathrm{m}^{-2}$ ) male subjects were selected to participate in the present study. This study was part of a greater project investigating postprandial protein handling in vivo in humans. ${ }^{1}$ Participants' characteristics are presented in Table 3.1. No differences were observed between groups (i.e. control vs insulin). All subjects were informed about the nature and possible risks of the experimental procedures, before their written informed consent was obtained. This study was approved by the Medical Ethical Committee of the Maastricht University Medical Centre and conforms to the principles outlined in the declaration of Helsinki for use of human subjects and tissue.

Table 3.1 Subjects' characteristics.

\begin{tabular}{|c|c|c|c|c|c|c|}
\hline & \multicolumn{2}{|c|}{ Young } & \multicolumn{2}{|c|}{ Older } & \multicolumn{2}{|c|}{$P$ value } \\
\hline & $\begin{array}{l}\text { Control } \\
(n=12)\end{array}$ & $\begin{array}{l}\text { Insulin } \\
(n=12)\end{array}$ & $\begin{array}{l}\text { Control } \\
(n=12)\end{array}$ & $\begin{array}{l}\text { Insulin } \\
(n=12)\end{array}$ & Age & Group \\
\hline Age (y) & $23 \pm 1$ & $21 \pm 1$ & $68 \pm 1$ & $68 \pm 0.7$ & $<0.001$ & 0.362 \\
\hline Weight (kg) & $72.5 \pm 1.8$ & $70.6 \pm 2.4$ & $78.8 \pm 2.4$ & $80.3 \pm 1.6$ & $<0.001$ & 0.834 \\
\hline BMI (kg) & $22.6 \pm 0.3$ & $21.3 \pm 0.5$ & $26.4 \pm 0.7$ & $26.2 \pm 0.5$ & $<0.001$ & 0.274 \\
\hline HbA1c (\%) & $5.2 \pm 0.1$ & $5.3 \pm 0.1$ & $5.6 \pm 0.1$ & $5.4 \pm 0.1$ & $<0.05$ & 0.524 \\
\hline Fasted glucose $\left(\mathrm{mmol} \cdot \mathrm{L}^{-1}\right)$ & $4.7 \pm 0.2$ & $4.8 \pm 0.1$ & $5.4 \pm 0.2$ & $5.1 \pm 0.2$ & $<0.05$ & 0.945 \\
\hline OGIS $\left(\mathrm{ml} \cdot \mathrm{min}^{-1} \cdot \mathrm{min}^{-1}\right)$ & $489 \pm 19$ & $470 \pm 11$ & $399 \pm 19$ & $404 \pm 12$ & $<0.001$ & 0.660 \\
\hline Blood pressure systolic (mmHg) & $123 \pm 2$ & $123 \pm 1$ & $134 \pm 3$ & $128 \pm 4$ & $<0.01$ & 0.272 \\
\hline Blood pressure diastolic $(\mathrm{mmHg})$ & $63 \pm 2$ & $60 \pm 1$ & $74 \pm 2$ & $72 \pm 3$ & $<0.001$ & 0.238 \\
\hline Leg volume (L) & $9.2 \pm 0.4$ & $8.9 \pm 0.4$ & $8.6 \pm 0.4$ & $8.5 \pm 0.3$ & 0.351 & 0.917 \\
\hline Leg lean mass (kg) & $10.1 \pm 0.3$ & $9.9 \pm 0.4$ & $9.7 \pm 0.3$ & $9.8 \pm 0.2$ & 0.625 & 0.846 \\
\hline Lean body mass (\%) & $81 \pm 1$ & $82 \pm 1$ & $77 \pm 1$ & $77 \pm 1$ & 0.059 & 0.788 \\
\hline Appendicular lean mass (\%) & $37 \pm 1$ & $37 \pm 1$ & $33 \pm 1$ & $33 \pm 1$ & 0.726 & 0.789 \\
\hline
\end{tabular}

$\mathrm{HbA1c}$, glycosylated hemoglobin. (Appendicular) lean body mass expressed as percentage of total body mass. Values are means \pm SEM. Data were analyzed by univariate ANOVA with age and treatment as factors. No differences were observed between groups receiving the control or insulin treatment.

\section{Pretesting}

Following an overnight fast, participants arrived at the laboratory at 8:30 AM by car or public transport. Blood pressure was measured after which a baseline blood sample was collected to determine blood count, plasma electrolytes, liver (ALAT) and renal (creatinine and urea) function, blood $\mathrm{HbA}_{1 \mathrm{c}}$ levels, and plasma glucose concentrations. Subsequently, an oral glucose tolerance test was performed to determine oral glucose intolerance and/or the presence of type 2 diabetes according to American Diabetes Association Guidelines. ${ }^{35}$ After glucose tolerance testing, leg volume was assessed as described by Jones and Pearson ${ }^{36}$ and body composition was measured with DXA (Lunar Prodigy Advance; GE Health Care, Madison, WI, USA). The system's software package 
(en-CORE 2005, version 9.15.00) was used to determine whole body and regional lean mass, fat mass and bone mineral content. Healthy subjects with screening results within normal limits and stable body weight for at least 3 months were included.

\section{Study design}

The experimental protocol is outlined in Supplemental Figure S3.1. Each subject participated in a single experiment in which postprandial protein handling was studied following the ingestion of $20 \mathrm{~g}$ intrinsically $\mathrm{L}-\left[1-{ }^{13} \mathrm{C}\right]$-phenylalanine and $\mathrm{L}-\left[1-{ }^{13} \mathrm{C}\right]$-leucine labeled casein protein. Antecubital venous and femoral arterial and venous lines were inserted ${ }^{37}$ for continuous intravenous L- $\left[\right.$ ing $\left._{-}{ }^{2} \mathrm{H}_{5}\right]$-phenylalanine, L-[ring- $\left.{ }^{2} \mathrm{H}_{2}\right]$-tyrosine, and $\mathrm{L}-\left[1-{ }^{13} \mathrm{C}\right]$-leucine tracer and indocyanine green (ICG) infusions ${ }^{38}$ and arterial and venous blood sampling. In 12 young and 12 older subjects, insulin was infused locally in the femoral artery during the first 2 hours following protein ingestion. Muscle biopsy tissue samples were collected from the vastus lateralis muscle before and 2 and $5 \mathrm{~h}$ after protein ingestion.

\section{Protocol}

All subjects were instructed to refrain from strenuous physical activity for 3 days prior to testing. Subjects refrained from alcohol and caffeine, and consumed a standard dinner $\left(33.9 \pm 0.8 \mathrm{~kJ} \cdot \mathrm{kg}^{-1}\right.$ body weight; providing 16 energy percent (en\%) protein, $33 \mathrm{en} \%$ carbohydrate, and 51 en\% fat) the evening prior to testing. The following morning, subjects arrived at the laboratory at 7:30 AM by car or public transportation. A polyethylene catheter was inserted into an antecubital vein for intravenous isotope tracer infusion. A second catheter was inserted into a dorsal hand vein of the contralateral arm and placed in a hot-box $\left(60^{\circ} \mathrm{C}\right)$ for arterialized blood sampling to measure background ICG, ${ }^{38}$ glucose, and insulin concentrations. Subsequently, the other 2 polyethylene catheters were inserted into the femoral artery and vein of the right leg for blood sampling. Ultrasound imaging was used to confirm safe insertion of the femoral lines. The arterial catheter was also used for the infusion of ICG (IC-Green; Akorn, Lake forest, II, USA). Following basal blood collection from the heated hand vein, femoral artery and femoral vein ( $t=-180 \mathrm{~min}$ ), the plasma phenylalanine, tyrosine and leucine pools were primed with a single intravenous dose of $2.000,0.615$ and $3.99 \mu \mathrm{mol} \mathrm{kg}^{-1}$, respectively, after which continuous tracer infusions $\left(0.050 \mu \mathrm{mol}^{\cdot 1} \mathrm{~kg} \cdot \mathrm{min}^{-1} \mathrm{~L}\right.$-[ring-$\left.{ }^{2} \mathrm{H}_{5}\right]$ phenylalanine, $0.015 \mu \mathrm{mol} \cdot{ }^{1} \mathrm{~kg} \cdot \mathrm{min}^{-1} \mathrm{~L}$-[ring- $\left.{ }^{2} \mathrm{H}_{2}\right]$-tyrosine, and $0.130 \mu \mathrm{mol}^{1} \mathrm{~kg} \cdot \mathrm{min}^{-1} \mathrm{~L}$-[1${ }^{13} \mathrm{C}$ ]-leucine) were administrated using a calibrated IVAC 560 pump (San Diego, USA) until the end of the experiment. After resting in a supine position for $60 \mathrm{~min}$, an arterialized blood sample from the heated hand vein, and an arterial and venous blood sample from the catheterized leg were drawn at $t=-120$ and $t=-60 \mathrm{~min}$. Subsequently, ICG was infused in the femoral artery $\left(1.0 \mathrm{mg} \cdot \mathrm{min}^{-1}\right)$ from $\mathrm{t}=-45 \mathrm{~min}$ until the end of the experiment $(\mathrm{t}=300 \mathrm{~min}$ ) with intervals as presented in Supplemental Figure S3.10. After collecting 
blood samples from the heated hand vein, femoral artery, and femoral vein at $t=0$ min, subjects received the test-drink containing $20 \mathrm{~g}$ intrinsically labeled casein protein and were asked to consume the drink within $5 \mathrm{~min}$. Following ingestion of the protein drink, blood samples from the heated hand vein, femoral artery, and femoral vein were collected at time points $\mathrm{t}=20,40,60,90,120,150,180,210,240,270$ and $300 \mathrm{~min}$. In addition, in 12 young and 12 older volunteers an euglycaemic-hyperinsulinaemic clamp was applied by local insulin infusion via the femoral artery at $0.30 \mathrm{mU} \cdot \mathrm{min}^{-1} \cdot 100 \mathrm{~mL}$ leg volume ${ }^{-1}$ between $t=15$ and $t=120$ min. $^{39} \mathrm{At} t=120 \mathrm{~min}$, insulin infusion was stopped, but glucose infusion was continued for $120 \pm 13 \mathrm{~min}$ to prevent hypoglycemia. Muscle biopsies were collected at $\mathrm{t}=0,120$ and $300 \mathrm{~min}$ after protein ingestion, using the percutaneous needle biopsy technique. ${ }^{40}$ Muscle samples were dissected carefully and freed from any visible non-muscle material, immediately frozen in liquid nitrogen and stored at $-80^{\circ} \mathrm{C}$ until further analysis. After the third biopsy, all infusions were stopped, catheters were removed, and the subjects were fed and discharged $\sim 3 \mathrm{~h}$ after removal of the femoral catheters.

\section{Plasma analysis}

Plasma glucose (Glucose HK CP, ABX Diagnostics, ref. A11A01667, Montpellier, France) concentrations were analyzed with a COBAS-FARA semi-automatic analyzer (Roche, Basel, Switzerland). Plasma insulin concentrations were determined by radioimmunoassay (Millipore, ref. HI-14K, Billerica, USA). ICG concentrations in plasma were determined spectrophotometrically as previously described. ${ }^{38}$ For determination of plasma amino acid concentrations, $10 \mu \mathrm{L}$ of plasma was mixed with $1500 \mu \mathrm{L} 0.5 \mathrm{mM}$ tridecafluoroheptanoic acid (TDFHA) (Sigma, Zwijndrecht, The Netherlands) in water and $10 \mu \mathrm{L}$ of the internal standard solution containing stable isotope-labeled amino acids (Cambridge Isotope Laboratories, Inc., Andover, USA) in $0.1 \mathrm{M} \mathrm{HCl}$. Amino acid profiles were determined using ultra-performance liquid chromatography tandem mass spectrometry (UPLC-MS/MS) as described previously. ${ }^{41}$ For measurement of plasma phenylalanine, tyrosine and leucine concentrations as well as $\mathrm{L}-\left[1-{ }^{13} \mathrm{C}\right]$-phenylalanine, L- $\left[1-{ }^{13} \mathrm{C}\right]$-tyrosine, L-[ring- $\left.{ }^{2} \mathrm{H}_{5}\right]$-phenylalanine, L-[ring- $\left.{ }^{2} \mathrm{H}_{4}\right]$-tyrosine and L-[ring- $\left.{ }^{2} \mathrm{H}_{2}\right]-$ tyrosine enrichments, plasma amino acids were derivatized to their t-butyldimethylsilyl (TBDMS) derivatives after the addition of an internal standard. Their concentrations and ${ }^{13} \mathrm{C}$ and/or ${ }^{2} \mathrm{H}$ enrichments were determined by electron ionization gas chromatographymass spectrometry (GC-MS, Agilent 6890N GC/5973N MSD Little Falls, USA) using selected ion monitoring of masses 336,337 and 341 for unlabeled and labeled $\left(\mathrm{L}-\left[1-{ }^{13} \mathrm{C}\right]\right.$ and $\mathrm{L}-\left[\right.$ ring- $\left.^{2} \mathrm{H}_{5}\right]$ ) phenylalanine, respectively. Masses 466, 467, 468 and 470 were assessed for unlabeled and labeled $\left(\mathrm{L}-\left[1-{ }^{13} \mathrm{C}\right], \mathrm{L}-\left[\right.\right.$ ring- $\left.{ }^{2} \mathrm{H}_{2}\right]$, and L-[ring- $\left.\left.{ }^{2} \mathrm{H}_{4}\right]\right)$ tyrosine and masses 302 and 303 were assessed for unlabeled and labeled (L-[1-13 C]-leucine), respectively. Albumin was extracted from blood samples by adding $20 \%$ perchloric acid (PCA). Samples were centrifuged at $3500 \mathrm{~g}$ at $4^{\circ} \mathrm{C}$ for $20 \mathrm{~min}$ after which the supernatant was removed. The mixed plasma protein pellet was washed and lyophilized to dryness. 
Amino acids were extracted by adding $6 \mathrm{~mol} \mathrm{~L}^{-1} \mathrm{HCl}$ and heated at $120^{\circ} \mathrm{C}$ for 15 to $18 \mathrm{~h}$. Thereafter, the hydrolyzed mixed plasma protein samples were processed via the same procedures as the muscle protein bound samples (described in the next paragraph). We applied standard regression curves in all isotopic enrichment analyses to assess linearity of the mass spectrometer and to control for the loss of tracer. Enrichments (MPE) were calculated according to Biolo et $a .^{42}$ to correct for the presence of naturally occurring isotopes.

\section{Muscle analyses}

For measurement of $\mathrm{L}-\left[1-{ }^{13} \mathrm{C}\right]$-leucine, L- $\left[1-{ }^{13} \mathrm{C}\right]$-phenylalanine and $\mathrm{L}-\left[\right.$ ring $\left.-{ }^{2} \mathrm{H}_{5}\right]-$ phenylalanine enrichment in the muscle free and muscle protein bound amino acid pool, $55 \mathrm{mg}$ wet muscle tissue was freeze dried. Collagen, blood, and other non-muscle fiber materials were removed from the muscle fibers under a light microscope. The isolated muscle fiber mass was weighed and 35 volumes (7x wet weight of isolated muscle fibers $x$ wet-to-dry ratio 5:1) of ice-cold 2\% PCA were added. Thereafter, the tissue was homogenized and centrifuged, with the supernatant being collected and processed in the same manner as the plasma samples, such that intracellular free $\mathrm{L}-\left[1-{ }^{13} \mathrm{C}\right]$-leucine, $\mathrm{L}-$ $\left[1-{ }^{13} \mathrm{C}\right]$-phenylalanine and L-[ring- $\left.{ }^{2} \mathrm{H}_{5}\right]$-phenylalanine enrichments could be measured using their TBDMS derivatives on a GC-MS. The protein pellet was washed for 3 additional $1.5 \mathrm{~mL}$ washes of $2 \%$ PCA, dried, and the hydrolyzed protein fraction was dried under a nitrogen steam while heated to $120^{\circ} \mathrm{C}$, then $50 \%$ acetic acid solution was added, and the hydrolyzed protein was passed over a Dowex exchange resin (AG 50W-X8, 100-200 mesh hydrogen form: Bio-Rad, Hercules, CA, USA) using $2 \mathrm{M} \mathrm{NH}_{4} \mathrm{OH}$. The eluate was divided over 2 vials for separate measurement of $\mathrm{L}-\left[1-{ }^{13} \mathrm{C}\right]$-leucine and $\mathrm{L}-\left[1-{ }^{13} \mathrm{C}\right]$-phenylalanine (GC-C-IRMS) and L-[ring- ${ }^{2} \mathrm{H}_{5}$ ]-phenylalanine (GC-MS) as described previously ${ }^{43}$. In short, $\mathrm{L}-\left[1-{ }^{13} \mathrm{C}\right]$-leucine and $\mathrm{L}-\left[1-{ }^{13} \mathrm{C}\right]$-phenylalanine were derivatized to their $\mathrm{N}(\mathrm{O}, \mathrm{S})$ ethoxycarbonyl ethyl esters and measured using Isotope Ratio Mass Spectrometer (IRMS, Thermo Scientific, GC Isolink/Mat 253) and L-[ring- $\left.{ }^{2} \mathrm{H}_{5}\right]$-phenylalanine became a TBDMS derivative of purified $\beta$-phenylethylamine produced by enzymatic decarboxylation, solvent extraction and was measured on the GC-MS. Standard regression curves were applied to assess linearity of the mass spectrometer and to control for the loss of tracer.

\section{Calculations}

Whole-body amino acid kinetics (expressed in $\mathrm{nmol}$ phenylalanine $\cdot \mathrm{kg} \mathrm{BW}^{-1} \cdot \mathrm{min}^{-1}$ ) in nonsteady state conditions were calculated from the ingestion of L- $\left[1-{ }^{13} \mathrm{C}\right]$-phenylalanine labeled protein with primed intravenous infusion of L-[ring- $\left.{ }^{2} \mathrm{H}_{5}\right]$-phenylalanine and L[ring-3,5- ${ }^{2} \mathrm{H}_{2}$ ]-tyrosine, with frequent venous and arterial blood sampling. Total, exogenous, and endogenous phenylalanine rates of appearance (Ra), as well as plasma phenylalanine availability (i.e. the fraction of dietary protein-derived phenylalanine that 
appeared in the systemic circulation; Phe plasma) were calculated using modified Steele's equations. ${ }^{44,45}$ Furthermore, total rate of phenylalanine disappearance (Rd), utilization of phenylalanine for protein synthesis, and phenylalanine hydroxylation (first step of phenylalanine conversion to tyrosine) were estimated. ${ }^{46}$ Whole-body net protein balance was calculated by subtracting protein synthesis from endogenous Ra and presented as the weighted mean over the $5 \mathrm{~h}$ ( $\mathrm{t}=0-300 \mathrm{~min}$ ) postprandial period. Phenylalanine and leucine kinetics were also used to study the two-pool and three-pool models which are based on the methodology as presented by Biolo and colleagues. ${ }^{47} \mathrm{We}$ also refer to an earlier publication from our lab for detailed explanation of the calculations. $^{1}$

\section{Statistics}

Forty-eight volunteers were included in the present experiment. All results are expressed as mean \pm standard error of the mean (SEM). Time-dependent variables were analyzed by repeated-measures ANOVA with treatment (insulin vs. control) and age (young vs. old) as between-subjects factor, and time as the within-subjects factor. The other variables were compared by univariate ANOVA. In case of amino acid uptake in the leg (Figure 3.3) and plasma amino acid availability (Figure 3.5B), only the main-effect of insulin was presented. In case of main effect of treatment and/or age, a post-hoc analysis (Bonferroni) was performed. Statistical significance was set at $P<0.05$. All calculations were performed using SPSS 21.0 (SPSS, Chicago, IL, USA).

\section{Results}

\section{Leg blood flow}

Leg blood flow did not change following protein ingestion $(P=0.559)$. Leg blood flow did

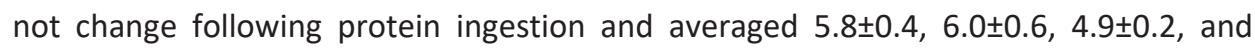
$5.1 \pm 0.4 \mathrm{~mL} \cdot \mathrm{min}^{-1} \cdot 100 \mathrm{~mL}$ leg volume ${ }^{-1}$ in the in young control, young insulin, older control and older insulin groups, respectively, and was applied for calculations containing blood flow. An interaction effect for blood flow (Time $x$ Age) was observed ( $P=0.042$ ), and a main effect for age $(P=0.004)$.

\section{Plasma insulin and glucose concentrations}

Basal and postprandial plasma insulin and glucose concentrations are presented in Figure 3.1A-C. Local insulin infusion in the femoral artery was applied between $t=15$ and 120 min in the young and older insulin-treated groups. Increases in plasma insulin concentrations in the leg femoral vein from $t=20-240 \min (A ; P<0.001)$, as well as the 
arterialized hand vein from $\mathrm{t}=20-180 \mathrm{~min}(\mathrm{~B} ; P<0.001)$ were observed during the infusion period in both insulin-treated groups, but not in the control group. Peak plasma insulin levels $\left(135 \pm 20\right.$ and $\left.140 \pm 18 \mathrm{mU} \cdot \mathrm{L}^{-1}\right)$ were reached at $\mathrm{t}=40$ and $\mathrm{t}=90 \mathrm{~min}$ in the young and older insulin-treated groups, respectively. Plasma glucose concentrations were lower in the control compared to insulin-treated groups ( $C ; P=0.042)$ and lower in the young compared with older groups $(P=0.033)$. Small but significant differences in plasma glucose concentrations $(P<0.001)$ between the control and insulin-treated groups were observed between $t=150-180$ min, i.e. after cessation of insulin administration.

\section{Plasma amino acid concentrations}

Plasma phenylalanine, leucine, and essential amino acids (EAA) concentrations are presented in Figure 3.2A-C. Following protein ingestion, amino acid concentrations increased in all groups $(P<0.001)$. Peak plasma amino acids concentrations were reached between 20 and 40 min after protein ingestion. Phenylalanine concentrations $(A)$ were significantly lower in the young compared to the older groups $(P=0.001)$. Insulin administration did not significantly change circulating plasma phenylalanine concentrations $(P=0.061)$. Postprandial leucine concentrations $(B)$ were lower in the insulin-treated compared with the control groups $(P<0.001)$ and lower in the young compared with the older groups $(P=0.028)$. The postprandial change in plasma leucine concentrations differed between young and older following insulin administration $(P=0.043)$, with a stronger postprandial decline in plasma leucine concentrations in the insulin-treated compared with the control groups $(P<0.001)$.

Amino acid leg inward (i.e., $F_{\text {in }}$ ) and leg outward (i.e., $F_{\text {out }}$ ) fluxes, and leg net balance during the postprandial phase $(t=0-300 \mathrm{~min})$ are presented for phenylalanine, leucine, and the sum of all essential amino acids in Figure 3.3A-C. Compared to the basal state (data not shown), all net balances became more positive following protein ingestion. Local insulin infusion resulted in a more positive phenylalanine $(A ; P<0.001)$ and leucine ( $B ; P<0.001$ ) net balance when compared to the control groups. For leucine, the more positive net balance was attributed mainly by a lower outward amino acid transport following local insulin administration (B). Differences in phenylalanine net balances were observed between the young and older groups ( $A ; P=0.049$ ). 
Local insulin

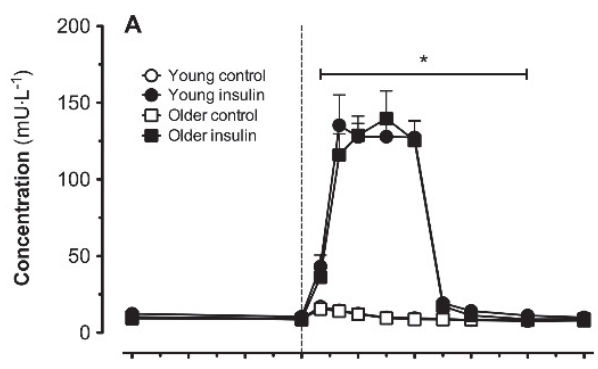

Systemic insulin

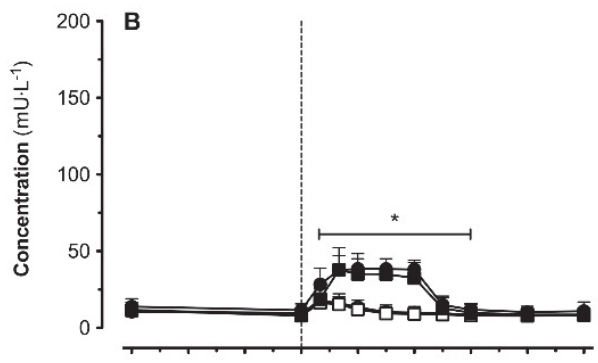

Systemic glucose

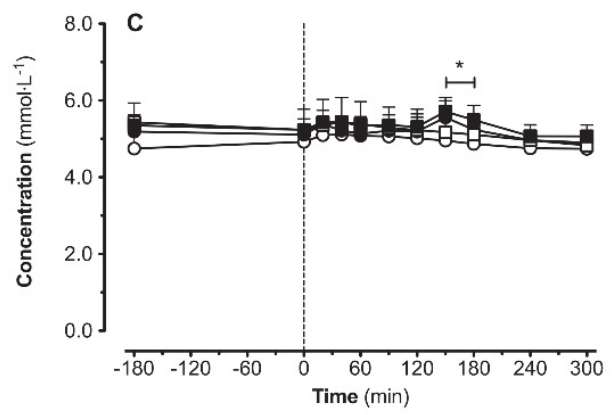

Figure 3.1 Plasma glucose and insulin concentrations. Local femoral vein plasma insulin (A), systemic plasma insulin (B) and systemic plasma glucose (C) concentrations in young and older subjects during the basal state and following ingestion of $20 \mathrm{~g}$ casein protein under normal (control) or insulinstimulated (insulin) conditions following exogenous insulin infusion in the femoral artery between $\mathrm{t}=15$ and $120 \mathrm{~min}$. Values are expressed as mean \pm SEM. * Indicates a main significant effect of insulin administration, $P<0.05$. 
Phenylalanine

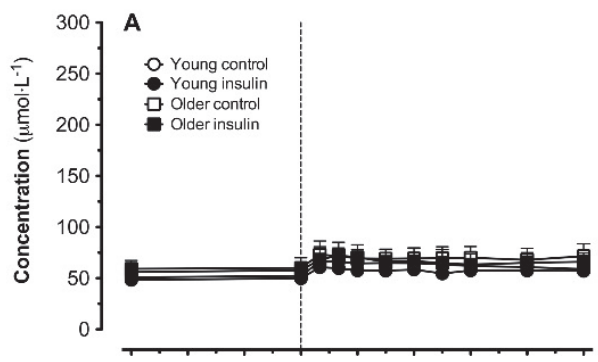

Leucine

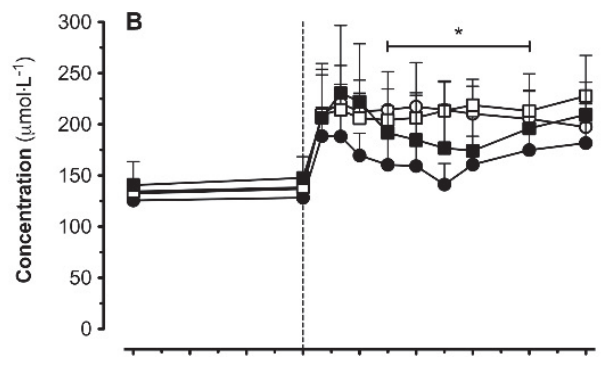

Essential amino acids

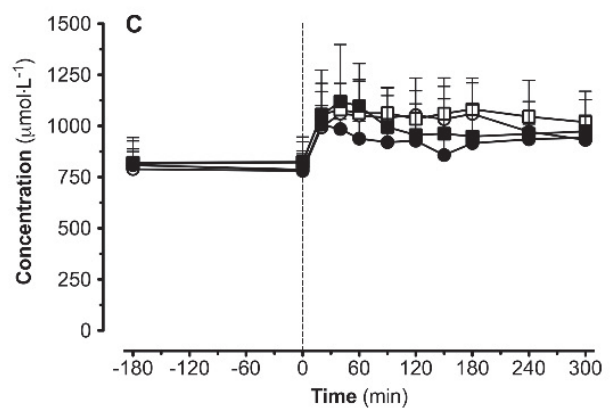

Figure 3.2 Plasma amino acid concentrations. Plasma phenylalanine (A), leucine (B) and essential amino acid (C) concentrations following the ingestion of $20 \mathrm{~g}$ protein in young and older men under normal (control) or insulin-stimulated (insulin) conditions following exogenous insulin infusion in the femoral artery between $\mathrm{t}=15$ and $\mathrm{t}=120 \mathrm{~min}$. Values are expressed as mean $\pm \mathrm{SEM}$. * Indicates a significant effect of insulin administration, $P<0.05$. 

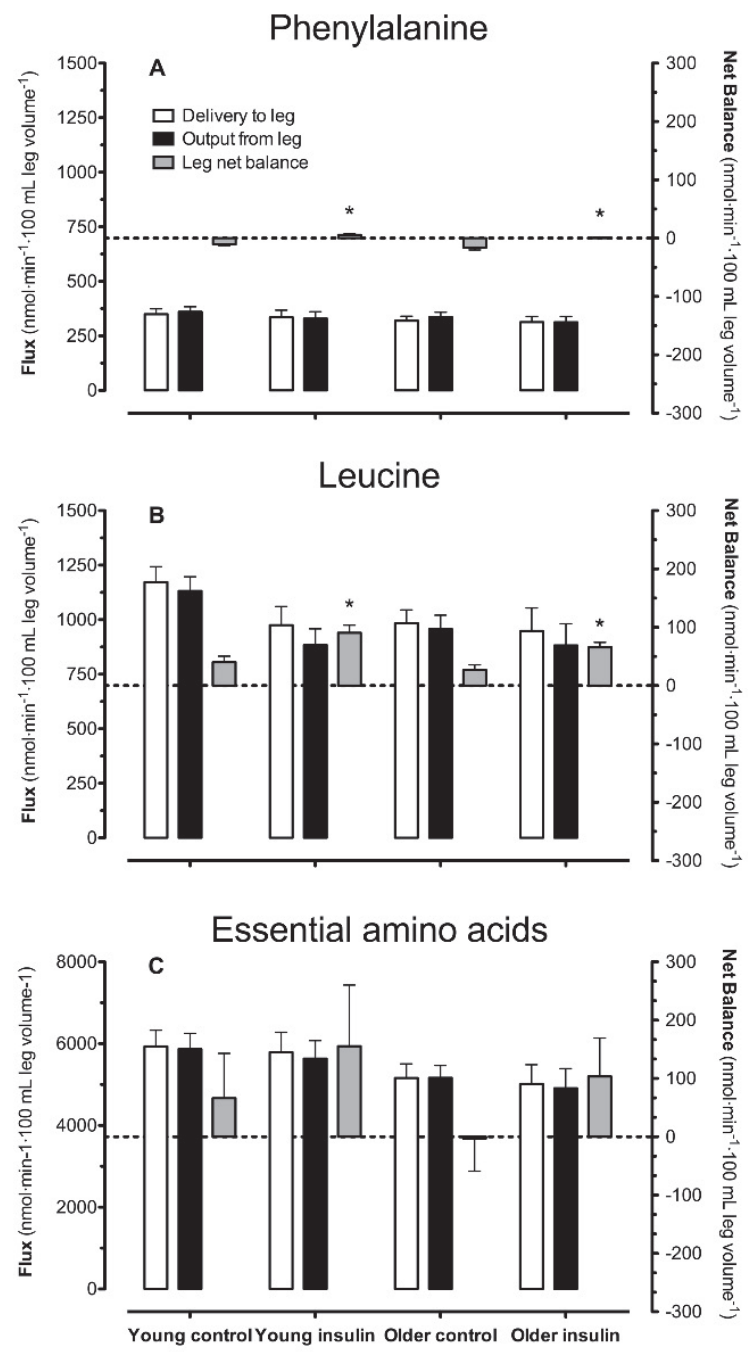

Figure 3.3 Amino acid uptake over the leg. Postprandial amino acid leg net balance following the ingestion of $20 \mathrm{~g}$ protein in young and older men protein under normal (control) or insulin-stimulated (insulin) conditions following exogenous insulin infusion in the femoral artery. Values are expressed as mean \pm SEM. * Indicates a significant effect of insulin administration, $P<0.05$.

\section{Plasma amino acid enrichments}

L-[ring ${ }^{2} \mathrm{H}_{5}$ ]-phenylalanine enrichments following continuous intravenous L-[ring- $\left.{ }^{2} \mathrm{H}_{5}\right]$ phenylalanine infusion declined immediately after protein ingestion, after which they remained stable in both the insulin treated and control groups (Figure 3.4A, D). 
Following the ingestion of intrinsically $\mathrm{L}-\left[1-{ }^{13} \mathrm{C}\right]$-phenylalanine-labeled casein protein, arterial and venous plasma $\mathrm{L}-\left[1-{ }^{13} \mathrm{C}\right]$-phenylalanine enrichments increased rapidly, reaching arterial peak levels of $9.0 \pm 0.7$ and 9.6 $\pm 0.7 \mathrm{MPE}$ in the young control and young insulin-treated groups at $\mathrm{t}=180 \mathrm{~min}$, respectively (Figure $3.4 \mathrm{~B}$ ) and $7.3 \pm 0.7$ and $8.2 \pm 0.8$ MPE in the older control and older insulin-treated groups, respectively, at $t=60 \mathrm{~min}$ (Figure 3.4E). Figure 3.4C and $\mathrm{F}$ show small but significant increases in $\mathrm{L}-\left[1{ }^{13} \mathrm{C}\right]$-leucine enrichments (from infused and ingested tracer) after protein ingestion $(P<0.001)$ in young and older men, respectively.

L-[ring- $\left.{ }^{2} \mathrm{H}_{5}\right]$-phenylalanine
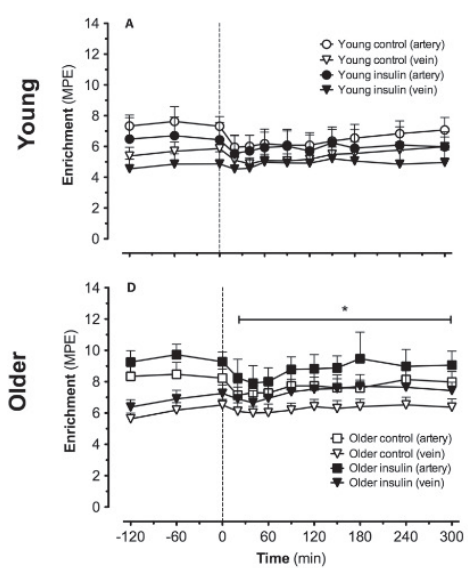

L-[1- $\left.{ }^{13} \mathrm{C}\right]-$ phenylalanine
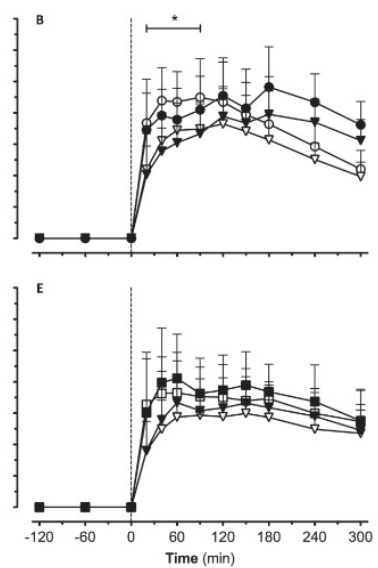

L- $\left[1-{ }^{13} \mathrm{C}\right]-$ leucine
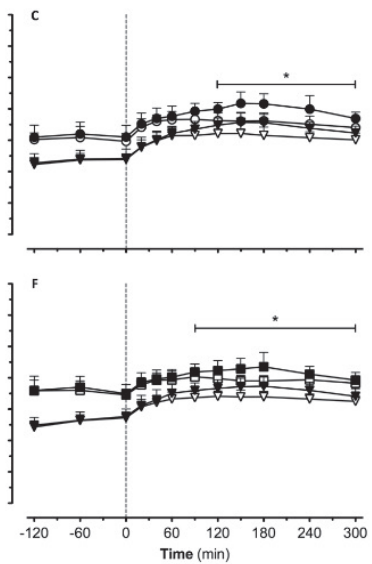

Figure 3.4 Plasma amino acid enrichments. Plasma L- $\left[\right.$ ring- $\left.{ }^{2} \mathrm{H}_{5}\right]$-phenylalanine, $\mathrm{L}-\left[1-{ }^{13} \mathrm{C}\right]-$ phenylalanine and $\mathrm{L}-\left[1-^{13} \mathrm{C}\right]$-leucine enrichments in artery and vein for following the ingestion of $20 \mathrm{~g}$ intrinsically L$\left[1-{ }^{13} \mathrm{C}\right]$-phenylalanine and $\mathrm{L}-\left[1-{ }^{13} \mathrm{C}\right]$-leucine enriched casein in young $(A, B, C$, respectively) and older men ( $D, E, F$, respectively) under normal (control) or insulin-stimulated (insulin) conditions. Values are expressed as mean \pm SEM. * : indicates a significant effect of insulin administration, $P<0.05$.

\section{Protein digestion and absorption}

Exogenous phenylalanine rates of appearance (Ra; i.e. the rate at which dietary proteinderived phenylalanine enters the circulation), as well as postprandial exogenous phenylalanine release (i.e. the percentage of dietary protein-derived phenylalanine becoming available in the circulation during the postprandial period) are presented in Figure 3.5A and $B$, respectively. A strong and significant increase in exogenous phenylalanine Ra was observed following protein ingestion in all groups $(P<0.001)$ and remained more elevated from $t=180-300 \mathrm{~min}$ in the young insulin-treated group compared with the other groups ( $A$; interaction effect: age $\mathrm{x}$ intervention: $P=0.023)$. Peak 
values were reached at $t=90,180,20$ and $40 \mathrm{~min}$ in the young control, young insulintreated, older control and older insulin-treated groups, respectively. Lower exogenous phenylalanine appearance rates were observed in the older compared with the young groups $(P<0.001)$. Dietary protein plasma phenylalanine availability was significantly higher for the young insulin-treated group, compared to the young control $(P=0.019)$ and older insulin-treated group $(P<0.001)(B)$.
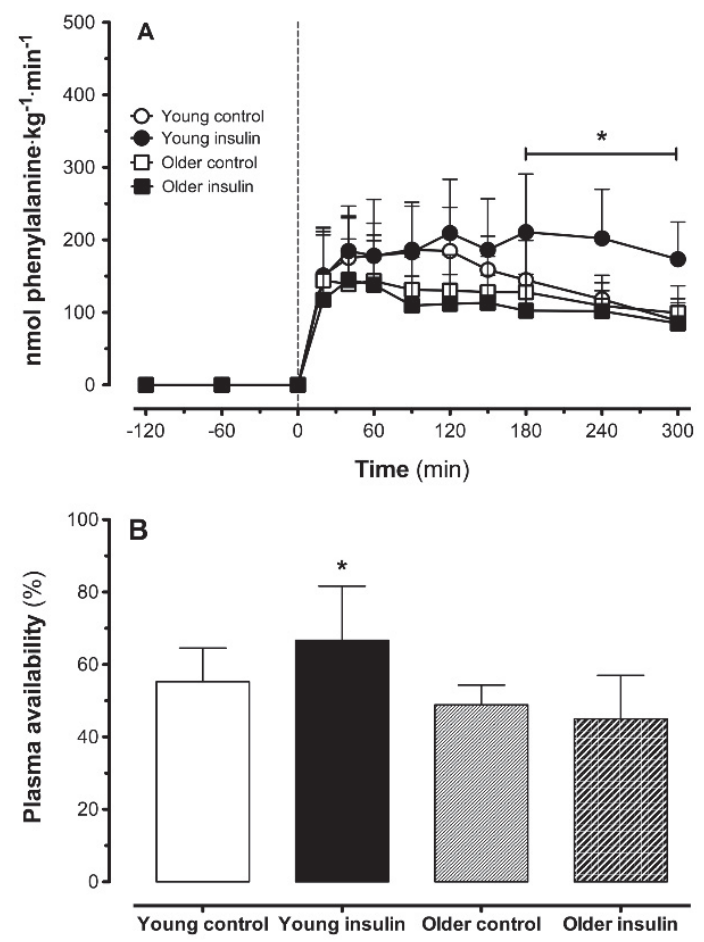

Figure 3.5 Exogenous phenylalanine rate of appearance. Exogenous rate of phenylalanine appearance $(A)$ and plasma phenylalanine bioavailability (B) following ingestion of $20 \mathrm{~g}$ protein under normal (control) or insulin-stimulated (insulin) conditions in young and older men. Values are expressed as mean \pm SEM. * significantly higher than young control $(P=0.019)$ and older insulin-stimulated $(P<0.001)$.

\section{Leg amino acid kinetics}

Leg basal and postprandial leucine net balance, based on the 3-pool calculations, are presented in Figure 3.6. In all groups, leg net balances (i.e., synthesis $\left(F_{o, m}\right)$ minus breakdown $\left.\left(F_{m, o}\right)\right)$ are negative in the basal state. After protein ingestion, leg net balance improved in all groups, becoming more positive in both insulin-treated and control groups $(P<0.001)$, with the response in the insulin-treated groups being greater than in 
the control groups $(P=0.003)$. No differences were observed in leg net balance between the young and older groups $(P=0.320)$.

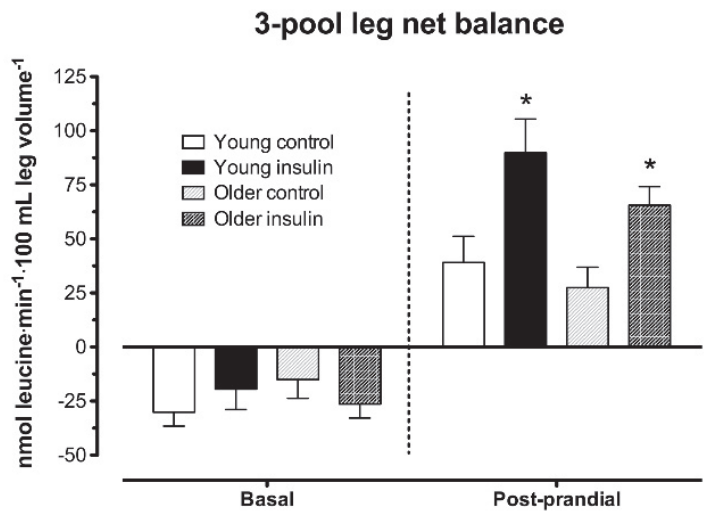

Figure 3.6 3 pool leg protein balance. 3-pool leg net balance, based on leg protein synthesis $\left(F_{0, M}\right)$ minus protein breakdown $\left(\mathrm{F}_{\mathrm{M}, 0}\right)$ following ingestion of $20 \mathrm{~g}$ protein under normal (control) or insulinstimulated (insulin) conditions in young $(n=20)$ and older $(n=23)$ volunteers. Values represent mean \pm SEM. * Indicates an effect of insulin, $P<0.05$.

\section{Plasma amino acid kinetics}

$\mathrm{L}$-[ring- ${ }^{2} \mathrm{H}_{5}$ ]-phenylalanine and L-[ring- $\left.{ }^{2} \mathrm{H}_{2}\right]$-tyrosine were used to calculate whole body amino acid kinetics (Figure 3.7). Whole body phenylalanine oxidation can be estimated from the conversion (hydroxylation) of L-[ring- $\left.{ }^{2} \mathrm{H}_{5}\right]$-phenylalanine to L-[ring- $\left.{ }^{2} \mathrm{H}_{4}\right]-$ tyrosine. Basal whole body net balance was more positive in the older compared with the young groups $(P<0.001)$. Whole body net balance improved after protein ingestion in both the young and older $(P<0.001)$ with a greater increase in the young compared to the older $(P=0.044)$. In the young, whole body net balance increased more in the insulintreated group than in the control group $(P=0.005)$. No differences in whole body net balance were observed between the older insulin-treated group and control group $(P=0.274)$. 


\section{Whole body net balance}

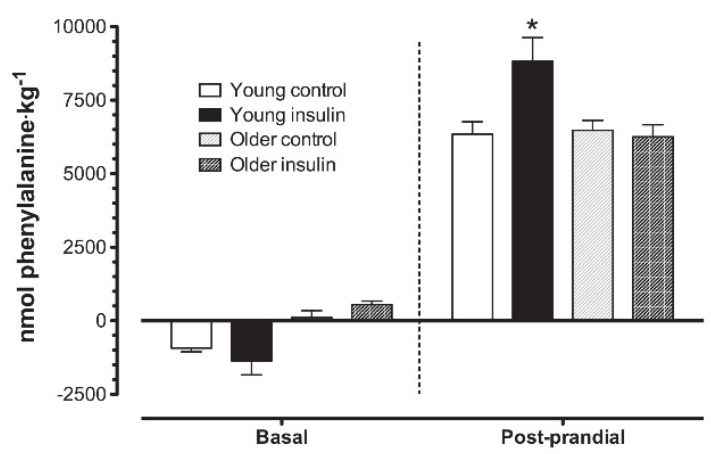

Figure 3.7 Phenylalanine whole body net balance. Rates of whole body net protein balance assessed during basal state and over the $5 \mathrm{~h}$ post-prandial period following ingestion of $20 \mathrm{~g}$ protein under normal (control) or insulin-stimulated (insulin) conditions in young and older men. Values represent mean \pm SEM. * Indicates an effect of insulin, $P<0.05$.

\section{3-pool kinetics}

Results of the 3-pool model calculations during de basal and postprandial period are presented in Table 3.2. Nearly all fluxes (expressed in $\mathrm{nmol} \cdot \mathrm{min}^{-1} \cdot 100 \mathrm{~mL}$ leg volume ${ }^{-1}$ ) significantly increased after protein ingestion, compared to basal, post-absorptive values in all groups. Insulin administration improved phenylalanine and leucine net balance significantly in both the young $(P=0.019$ and $P<0.001$, respectively) and older $(P=0.003$ and $P=0.007$, respectively) insulin-treated groups.

\section{Muscle analysis}

Muscle biopsies were obtained at $\mathrm{t}=0,120$ and $300 \mathrm{~min}$. Plasma albumin obtained prior to tracer infusion was used to determine baseline L-[ring- $\left.{ }^{2} \mathrm{H}_{5}\right]$-phenylalanine enrichments. Basal muscle protein synthesis rates were calculated by using the single biopsy approach as validated previously for $\mathrm{L}-\left[\mathrm{ring}^{2}{ }^{2} \mathrm{H}_{5}\right]$-phenylalanine ${ }^{48}$ Muscle-free and muscle protein bound tissue enrichments of L-[ring- $\left.{ }^{2} \mathrm{H}_{5}\right]$-phenylalanine, $\mathrm{L}-\left[1-{ }^{13} \mathrm{C}\right]$-leucine and $\mathrm{L}-\left[1-{ }^{13} \mathrm{C}\right]$-phenylalanine are summarized in Table 3.3. Mixed muscle-free L-[ring- $\left.{ }^{2} \mathrm{H}_{5}\right]-$ phenylalanine enrichments were higher in the young compared to the older groups $(P=0.001)$ and increased between baseline and $\mathrm{t}=300 \mathrm{~min}$ in all groups $(P=0.003)$. At $\mathrm{t}=300 \mathrm{~min}$, muscle free $\mathrm{L}-\left[1-{ }^{13} \mathrm{C}\right]$-leucine enrichments were greater in insulin-treated compared with the control groups $(P=0.031)$ and higher in the older compared to the younger groups $(P=0.007)$. 


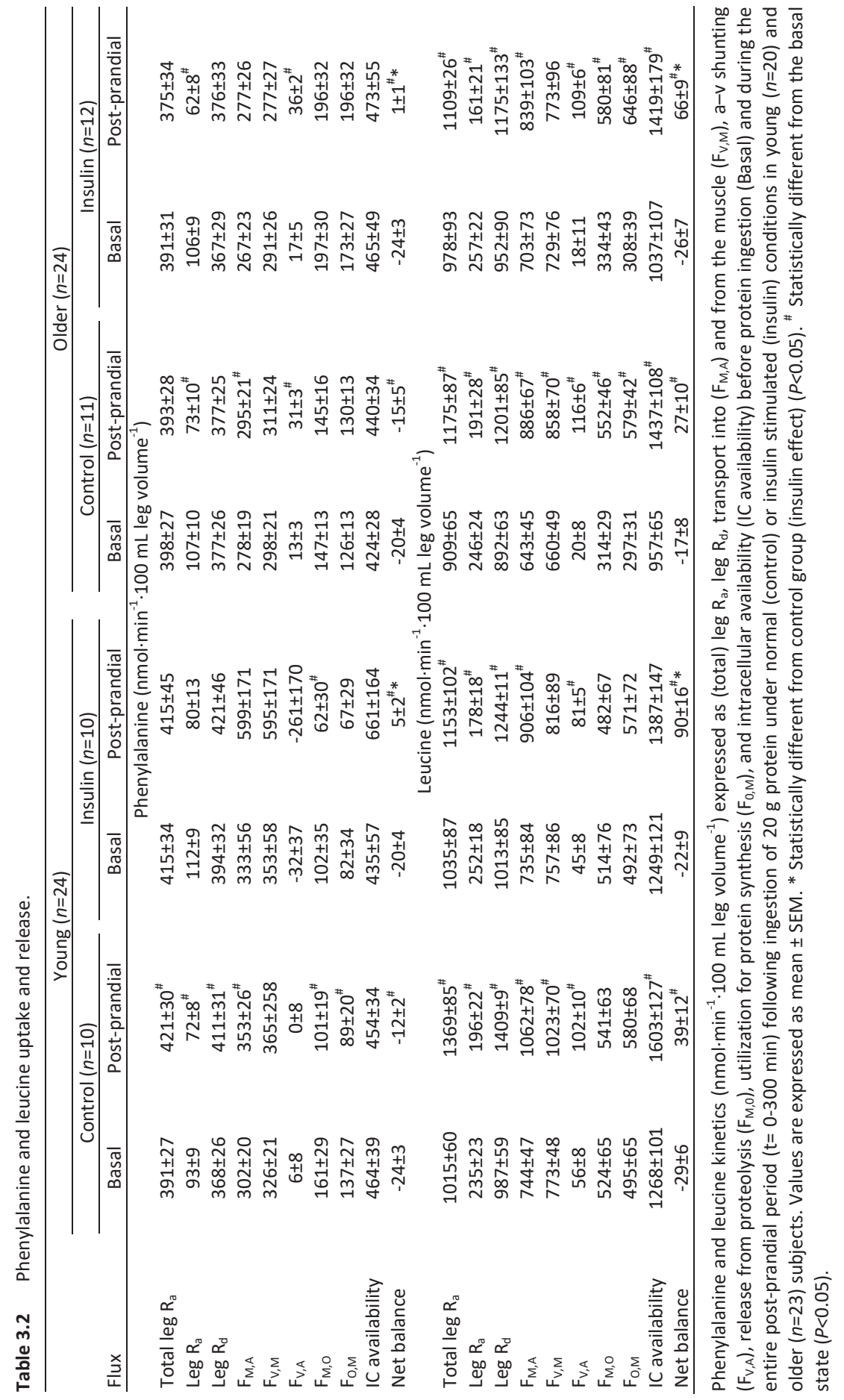


Table 3.3 Muscle free tissue and muscle protein bound enrichments (MPE).

\begin{tabular}{|c|c|c|c|c|c|c|}
\hline \multicolumn{7}{|c|}{ Muscle free tissue (MPE) } \\
\hline $\begin{array}{l}\text { Tracer } \\
\text { (MPE) }\end{array}$ & Group $(n=12)$ & $\begin{array}{l}-180 \\
\min \end{array}$ & $0 \mathrm{~min}$ & $120 \mathrm{~min}$ & $300 \mathrm{~min}$ & P-values \\
\hline \multicolumn{7}{|c|}{ L-[ring $\left.{ }^{2} \mathrm{H}_{5}\right]$-phenylalanine } \\
\hline & Young control & 0 & $4.937 \pm 0.228$ & $5.136 \pm 0.285$ & $5.224 \pm 0.229$ & Time: $P=0.03$ \\
\hline & Young insulin & 0 & $4.852 \pm 0.251$ & $5.043 \pm 0.189$ & $5.099 \pm 0.181$ & Age: $P=0.01$ \\
\hline & Older control & 0 & $5.312 \pm 0.126$ & $5.592 \pm 0.169$ & $5.583 \pm 0.183$ & \\
\hline & Older insulin & 0 & $5.510 \pm 0.283$ & $5.535 \pm 0.232$ & $6.100 \pm 0.278^{a}$ & \\
\hline \multicolumn{7}{|c|}{$\mathrm{L}-\left[1-{ }^{13} \mathrm{C}\right]$-leucine } \\
\hline & Young control & & 0 & $5.372 \pm 0.232$ & $4.831 \pm 0.220$ & Time $\times$ intervention: $P=0.011$ \\
\hline & Young insulin & & 0 & $5.379 \pm 0.212$ & $5.384 \pm 0.226$ & Time $\times$ Age: $P=0.008$ \\
\hline & Older control & & 0 & $5.596 \pm 0.169$ & $5.505 \pm 0.121^{b}$ & \\
\hline & Older insulin & & 0 & $5.449 \pm 0.202$ & $5.837 \pm 0.205$ & \\
\hline \multicolumn{7}{|c|}{$\mathrm{L}-\left[1-{ }^{13} \mathrm{C}\right]$-phenylalanine } \\
\hline & Young control & & 0 & $5.658 \pm 0.585$ & $3.310 \pm 0.296$ & Time $\times$ Intervention: $P=0.037$ \\
\hline & Young insulin & & 0 & $5.337 \pm 0.516$ & $5.110 \pm 0.484^{b}$ & Time: $P=0.012$ \\
\hline & Older control & & 0 & $4.176 \pm 0.361$ & $3.702 \pm 0.213$ & Age: $P=0.006$ \\
\hline & Older insulin & & 0 & $4.051 \pm 0.376$ & $4.118 \pm 0.361$ & \\
\hline \multicolumn{7}{|c|}{ Muscle protein bound tissue (MPE) } \\
\hline \multicolumn{7}{|c|}{$\mathrm{L}-\left[\right.$ ring- $\left.{ }^{2} \mathrm{H}_{5}\right]-$ phenylalanine } \\
\hline & Young control & 0 & $0.0066 \pm 0.0005$ & $0.0127 \pm 0.0007$ & $0.0213 \pm 0.0013$ & Time: $P<0.001$ \\
\hline & Young insulin & 0 & $0.0061 \pm 0.0004$ & $0.0121 \pm 0.0007$ & $0.0209 \pm 0.0013$ & \\
\hline & Older control & 0 & $0.0060 \pm 0.0002$ & $0.0120 \pm 0.0006$ & $0.0206 \pm 0.0010$ & \\
\hline & Older insulin & 0 & $0.0063 \pm 0.0006$ & $0.0122 \pm 0.0010$ & $0.0229 \pm 0.0019^{a}$ & \\
\hline \multicolumn{7}{|c|}{$\mathrm{L}-\left[1-{ }^{13} \mathrm{C}\right]$-leucine } \\
\hline & Young control & & 0 & $0.0112 \pm 0.0018$ & $0.0204 \pm 0.0017$ & Time: $P<0.001$ \\
\hline & Young insulin & & 0 & $0.0065 \pm 0.0024$ & $0.0212 \pm 0.0044$ & Age: $P=0.012$ \\
\hline & Older control & & 0 & $0.0017 \pm 0.0032^{b}$ & $0.0133 \pm 0.0036$ & \\
\hline & Older insulin & & 0 & $0.0031 \pm 0.0013$ & $0.0156 \pm 0.0018$ & \\
\hline \multicolumn{7}{|c|}{$\mathrm{L}-\left[1-{ }^{13} \mathrm{C}\right]$-phenylalanine } \\
\hline & Young control & & 0 & $0.0057 \pm 0.0018$ & $0.0197 \pm 0.0027$ & Time $\times$ Age: $P=0.044$ \\
\hline & Young insulin & & 0 & $0.0049 \pm 0.0013$ & $0.0198 \pm 0.0026$ & Time: $P<0.001$ \\
\hline & Older control & & 0 & $0.0068 \pm 0.0013$ & $0.0161 \pm 0.0020$ & \\
\hline & Older insulin & & 0 & $0.0050 \pm 0.0012$ & $0.0168 \pm 0.0022$ & \\
\hline
\end{tabular}

Muscle tissue-free and muscle protein bound enrichments at the start of the experiment ( $t=-180 \mathrm{~min})$, the end of the basal period ( $t=0 \mathrm{~min})$, the early $(t=120 \mathrm{~min}$ ) and the late $(t=300 \mathrm{~min}$ ) stages of the postprandial phase (MPE) following ingestion of $20 \mathrm{~g}$ protein under normal (control) or insulin stimulated (insulin) conditions in young $(n=20)$ and older $(n=23)$ subjects. Muscle free and muscle protein bound L-[ring- $\left.{ }^{2} \mathrm{H}_{5}\right]$-phenylalanine enrichments at $\mathrm{t}=-180 \mathrm{~min}$ were assessed based upon plasma albumin as an alternative of a baseline biopsy sample as described previously. ${ }^{48}$ Values are expressed as mean \pm SEM. Data were analyzed by repeated measures ANOVA. ${ }^{a}$ Statistically different from young insulin-treated $(P<0.05)$. ${ }^{\text {b }}$ Statistically different from young control $(P<0.05)$.

Mixed muscle protein fractional synthetic rates, based on the L-[ring- $\left.{ }^{2} \mathrm{H}_{5}\right]$-phenylalanine plasma precursor pool, are presented in Figure 3.8. After $5 \mathrm{~h}, \mathrm{FSR}$ values increased significantly in all groups after protein ingestion (from $0.029 \pm 0.002,0.031 \pm 0.003$, $0.023 \pm 0.001,0.024 \pm 0.003$ to $0.044 \pm 0.004,0.050 \pm 0.006,0.037 \pm 0.002,0.037 \pm 0.002 \% \cdot h^{-1}$ in the young control, young insulin-treated, older control, older insulin-treated groups, 
respectively; $P<0.001)$. Muscle protein synthesis rates were lower in the older compared with the young $(P=0.003)$. Local insulin administration did not increase post-prandial muscle protein synthesis rates $(P=0.804)$.

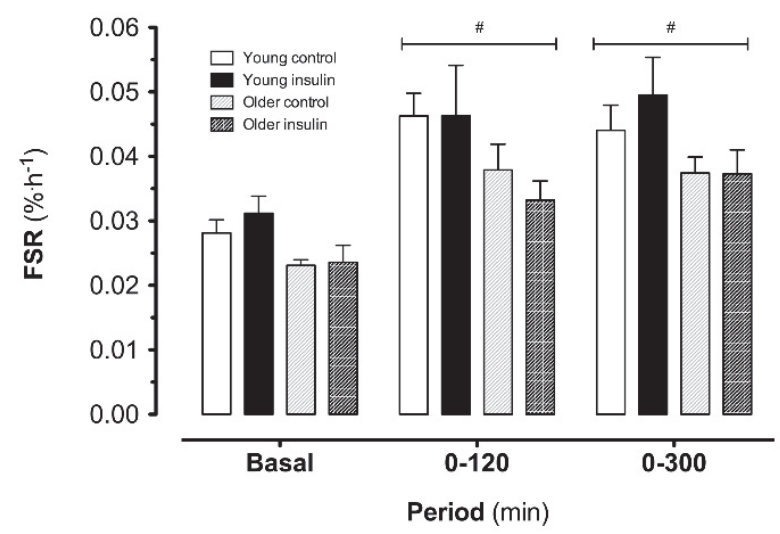

Figure 3.8 Mixed muscle fractional synthetic rates. Mixed muscle protein FSR based on L-[ring- $\left.{ }^{2} \mathrm{H}_{5}\right]-$ phenylalanine during the basal ( $\mathrm{t}=-180-0 \mathrm{~min}$ ), early postprandial $(\mathrm{t}=0-120 \mathrm{~min}$ ) and total postprandial ( $\mathrm{t}=0-300 \mathrm{~min}$ ) phase following ingestion of $20 \mathrm{~g}$ protein under normal (control) or insulin-stimulated (insulin) conditions in young $(n=20)$ and older $(n=23)$ volunteers. Values represent mean \pm SEM. \# higher than basal values $(P<0.05)$. No significant effects of insulin were observed.

Mixed muscle protein-bound $\mathrm{L}-\left[1-{ }^{13} \mathrm{C}\right]$-phenylalanine enrichments are presented in Figure 3.9. Enrichments increased over time $(P<0.001)$ in all groups and greater increases were observed in the young compared with the older groups $(P=0.044)$. Local insulin administration did not augment the postprandial increase in mixed muscle protein bound L- $\left[1-{ }^{13} \mathrm{C}\right]$-phenylalanine enrichments $(P=0.419)$. 


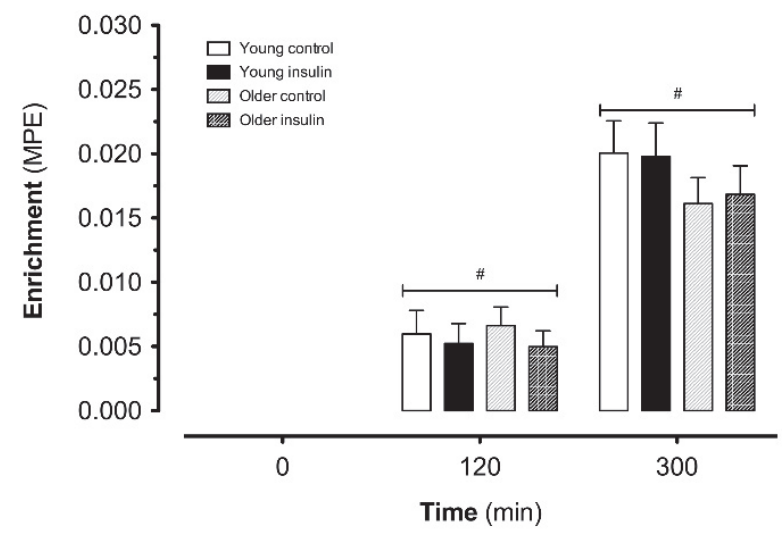

Figure 3.9 Muscle protein bound amino acid enrichments. Mixed muscle protein-bound L-[1- $\left.{ }^{13} \mathrm{C}\right]-$ phenylalanine enrichments (MPE) at $t=120$ and $t=300 \mathrm{~min}(\mathrm{~B})$ following ingestion of $20 \mathrm{~g}$ protein under normal (control) or insulin-stimulated (insulin) conditions in young $(n=20)$ and older $(n=23)$ volunteers. Values represent mean \pm SEM. \# higher than basal values $(P<0.05)$. No significant effects of insulin were observed.

\section{Discussion}

In the present study we observed no differences in dietary protein digestion and amino acid absorption, postprandial plasma amino acid availability, or amino acid uptake over the leg between young and older men. Increasing postprandial insulin availability by exogenous insulin administration increased postprandial amino acid uptake over the leg, but did not augment postprandial muscle protein synthesis rates in the young or older subjects. Though there were ample signs of anabolic resistance in the older group, increasing insulin availability did not increase postprandial muscle protein synthesis rates or augment the postprandial deposition of dietary protein derived amino acids in de novo muscle protein. Our data proof that the postprandial rise in circulating insulin levels is permissive rather than modulatory in regulating post-prandial protein metabolism.

Food intake, and protein ingestion in particular, have been shown to increase muscle protein synthesis rates. We previously assessed postprandial protein handling in vivo in humans, by the combined application of ingesting intrinsically L- $\left[1-{ }^{13} \mathrm{C}\right]$-phenylalanine labeled dietary protein with continuous infusions of L-[ring- $\left.{ }^{2} \mathrm{H}_{5}\right]$-phenylalanine and $\mathrm{L}-\left[1-{ }^{13} \mathrm{C}\right]$-leucine. ${ }^{1}$ We extend on these recent data by assessing the impact of both age and postprandial insulin availability on postprandial protein handling. A total of 24 young (age $22 \pm 1 \mathrm{y}$ ) and 24 older (age $68 \pm 1$ y) men ingested a meal-like amount of intrinsically labeled casein protein with or without additional insulin administrated via the femoral artery at a rate of $0.30 \mathrm{mU} \cdot \mathrm{min}^{-1} \cdot 100 \mathrm{~mL}$ leg volume ${ }^{-1}$ during a $2 \mathrm{~h}$ period (Supplemental Figure S3.1). We applied this insulin administration protocol to transiently increase postprandial insulin availability, mimicking a physiological insulin response that can be 
observed after ingestion of a large mixed meal. ${ }^{49}$ As a result, we managed to augment postprandial insulin availability by increasing insulin levels up to $150 \mathrm{mU} \cdot \mathrm{L}^{-1}$ during the first $2 \mathrm{~h}$ after protein ingestion in the insulin stimulated condition compared with insulin levels of $\sim 50 \mathrm{mU} \cdot \mathrm{L}^{-1}$ in the control setting (Figure 3.1). This allows us to assess the impact of transient, physiological increases in insulin availability on postprandial protein handling in vivo in humans.

Following protein ingestion, plasma amino acid concentrations increased and remained elevated throughout the remainder of the $5 \mathrm{~h}$ postprandial period in all groups (Figure 3.2). The increase in plasma amino acid concentrations originated from the digestion and absorption of the ingested protein, as evidenced from the postprandial increase in both plasma phenylalanine concentrations and plasma $\mathrm{L}-\left[1-{ }^{13} \mathrm{C}\right]$-phenylalanine enrichments (Figure 3.4). A total of $55 \pm 3 \%$ of the ingested protein derived phenylalanine had become available in the circulation during a $5 \mathrm{~h}$ postprandial period in the young control group (Figure 3.5). We extend on these previously published findings ${ }^{1}$ by showing a lower postprandial release of dietary protein derived amino acids in healthy older compared with young subjects ( $49 \pm 2$ and $55 \pm 3 \%$, respectively; $P<0.001$; Figure 3.5 ). Though we did not expect any impact of greater postprandial insulin availability on protein digestion and amino acid absorption kinetics, we observed greater postprandial (dietary protein derived) amino acid availability in the young insulin stimulated compared with the control condition in the young males ( $67 \pm 4$ vs. $55 \pm 3 \%$; $P<0.019$ ); Figure 3.5 ). We can only speculate on the mechanisms responsible for the greater postprandial amino acid release in the insulin stimulated condition in the young group. It seems logical to assume that insulin stimulated plasma amino acid disposal favors a more sustained release of dietary protein derived amino acids from the splanchnic tissues towards the circulation, thereby lowering splanchnic amino acid retention (Figure 3.6).

The postprandial release of dietary protein derived amino acids in the circulation increased amino acid uptake over the leg in both the young and older subjects, thereby improving amino acid balance over the leg (Figure 3.3 and 3.6). Whereas a net negative amino acid balance was observed in the basal fasted state, dietary protein ingestion resulted in a positive protein balance in both the young and older groups, with no apparent differences between the young and older (Figure 3.6). The increase in postprandial insulin availability in the insulin-stimulated condition more than doubled net amino acid uptake over the leg in both age groups $(P=0.003)$, with no differences between the young and older men $(P=0.320)$. These findings are in line with the proposed stimulation of amino acid transmembrane transport by physiological levels of hyperinsulinemia ${ }^{50}$ and agree with the outcome of a recent meta-analyses summarizing the impact of exogenous insulin administration on amino acid uptake over the leg in vivo in humans. ${ }^{51}$ Previous work has generally applied hyperinsulinemic clamps to proof the efficacy of insulin to promote amino acid extraction over the leg. The present findings extend on the previous work by showing that even a short, transient, physiological 
increase in postprandial insulin availability strongly augments amino acid extraction by skeletal muscle tissue.

The postprandial increase in plasma amino acid availability and subsequent stimulation of amino acid uptake increased whole-body protein synthesis rates and inhibited wholebody protein breakdown, resulting in a (more) positive whole-body protein balance in both the young and older groups (Figure 3.7). Interestingly, the greater post-prandial amino acid availability in the insulin-stimulated condition in the young group further increased whole-body net protein balance $(P<0.05)$. However, these estimates of wholebody protein synthesis and breakdown rates do not (necessarily) reflect changes in skeletal muscle protein synthesis or breakdown rates. Therefore, we obtained multiple skeletal muscle biopsies from the vastus lateralis muscle to assess both mixed muscle protein synthesis rates and evaluate the deposition of dietary protein derived L-[1- $\left.{ }^{13} \mathrm{C}\right]-$ phenylalanine deposition in de novo muscle protein within a $5 \mathrm{~h}$ postprandial period. Dietary protein ingestion significantly increased muscle protein synthesis rates during both the early and overall $5 \mathrm{~h}$ postprandial phase $(P<0.001$; Figure 3.8$)$. Postprandial muscle protein synthesis rates were significantly lower in the older compared with the young males $(P=0.024)$ indicative of anabolic resistance in the older males. ${ }^{28,52}$ Despite the greater amino acid uptake over the leg in the insulin stimulated condition in both the young and older subjects (Figure 3.6), greater post-prandial insulin stimulation did not result in a further increase in postprandial muscle protein synthesis rates in both the young and older groups (Figure 3.8). The latter agrees with Greenhaff et al. assessing the impact of intravenous amino acid infusion on muscle protein synthesis under various (clamped) insulin levels. ${ }^{16}$ Even in the older males, who show signs of anabolic resistance to protein feeding, we were unable to increase postprandial muscle protein synthesis rates by increasing postprandial insulin availability. Consequently, postprandial insulin levels equal to or below $\sim 50 \mathrm{mU} \cdot \mathrm{L}^{-1}$ (Figure 3.1 ) were sufficient to allow maximal postprandial stimulation of postprandial muscle protein synthesis in both the young and older males. Though previous findings have shown that local insulin administration increases muscle protein synthesis rates the present data extend on this previous work by the observation that exogenous insulin administration does not further augment the postprandial rise in muscle protein synthesis rates. ${ }^{39,53,54}$

Besides measuring postprandial muscle protein synthesis rates by the incorporation of L[ring- $\left.{ }^{2} \mathrm{H}_{5}\right]$-phenylalanine and $\mathrm{L}-\left[1-{ }^{13} \mathrm{C}\right]$-leucine in mixed muscle protein following continuous intravenous $\mathrm{L}-\left[\right.$ ring $\left.-{ }^{2} \mathrm{H}_{5}\right]$-phenylalanine and $\mathrm{L}-\left[1-{ }^{13} \mathrm{C}\right]$-leucine infusion, we also measured the incorporation of dietary protein derived $\mathrm{L}-\left[1-{ }^{13} \mathrm{C}\right]$-phenylalanine in de novo muscle protein (Figure 3.9). The latter showed substantial deposition of dietary protein derived phenylalanine in de novo muscle protein following 2 and $5 \mathrm{~h}$ after the ingestion of $20 \mathrm{~g}$ intrinsically labeled protein. Significantly smaller increases in $\mathrm{L}-\left[1-{ }^{13} \mathrm{C}\right]-$ phenylalanine incorporation in skeletal muscle protein were observed in the healthy older compared to the young males $(P=0.044)$, again showing evidence of anabolic resistance. In line with the postprandial muscle protein synthesis rates, we could not 
detect greater postprandial protein derived amino acid deposition in muscle protein under insulin-stimulated conditions $(P>0.05)$. Despite greater postprandial phenylalanine uptake over the leg in the insulin stimulated condition, no increase in postprandial muscle protein accretion was observed in either the young or older males. These findings extend on prior work demonstrating that the postprandial rise in muscle protein synthesis rate is transient even when amino acid availability remains elevated, a phenomenon sometimes referred to as the 'muscle full effect'. ${ }^{55,56}$

The present study is the first to show that transient, physiological increases in postprandial insulin availability do not further augment the postprandial increase in muscle protein synthesis rates or modulate the metabolic fate of the dietary protein derived amino acids during an integrated $5 \mathrm{~h}$ postprandial period in either healthy young or older men. Consequently, it seems evident that postprandial insulin levels are merely permissive and not modulatory in facilitating the postprandial rise in muscle protein synthesis following the ingestion of a meal-like amount of protein. Clearly, other factors than insulin availability or amino acid precursor availability seem to restrict the postprandial rise in muscle protein synthesis in both healthy young as well as older men.

In conclusion, greater postprandial plasma insulin availability stimulates amino acid uptake over the leg but does not further augment the postprandial muscle protein synthetic response to protein feeding in healthy young and older males. Therefore, the postprandial rise in circulating insulin should be regarded as permissive rather than modulatory in driving the postprandial increase in muscle protein synthesis rates in both healthy young and older men. 


\section{Supplemental figure}

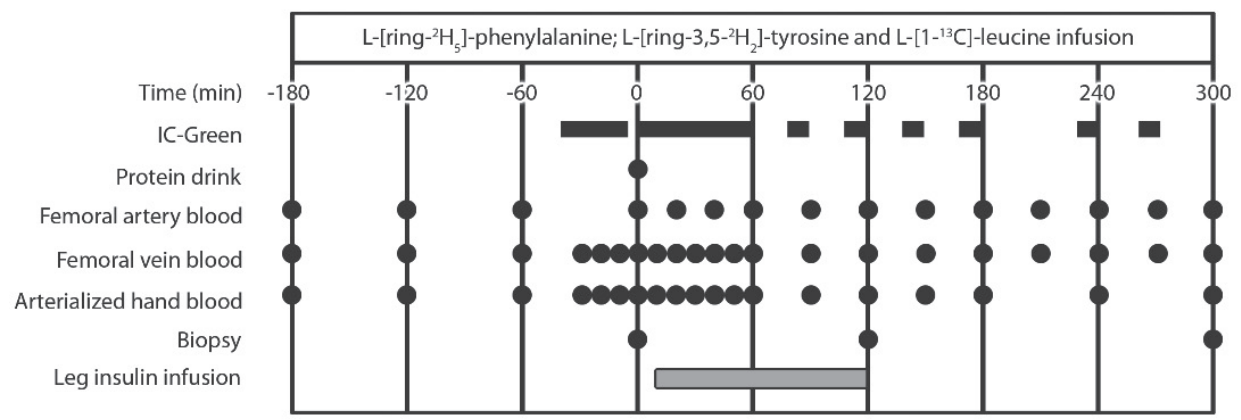

Figure S3.1 Outline of the experimental protocol. 


\section{References}

1. Groen BB, Horstman AM, Hamer HM, de Haan M, van Kranenburg J, Bierau J, et al. Postprandial protein handling: You are what you just ate. PLoS One. 2015;10(11):e0141582.

2. Tessari P, Garibotto G, Inchiostro S, Robaudo C, Saffioti S, Vettore M, et al. Kidney, splanchnic, and leg protein turnover in humans. Insight from leucine and phenylalanine kinetics. J Clin Invest. 1996;98(6):1481-92.

3. Pennings B, Koopman R, Beelen M, Senden JM, Saris WH, van Loon LJ. Exercising before protein intake allows for greater use of dietary protein-derived amino acids for de novo muscle protein synthesis in both young and elderly men. The American journal of clinical nutrition. 2011;93(2):322-31.

4. Rasmussen BB, Fujita S, Wolfe RR, Mittendorfer B, Roy M, Rowe VL, et al. Insulin resistance of muscle protein metabolism in aging. FASEB J. 2006;20(6):768-9.

5. Timmerman KL, Lee JL, Fujita S, Dhanani S, Dreyer HC, Fry CS, et al. Pharmacological vasodilation improves insulin-stimulated muscle protein anabolism but not glucose utilization in older adults. Diabetes. 2010;59(11):2764-71.

6. Drummond M, Glynn E, Fry C, Timmerman K, Volpi E, Rasmussen B. An increase in essential amino acid availability upregulates amino acid transporter expression in human skeletal muscle. American journal of physiology Endocrinology and metabolism. 2010;298(5):8.

7. Cuthbertson D, Smith K, Babraj J, Leese G, Waddell T, Atherton P, et al. Anabolic signaling deficits underlie amino acid resistance of wasting, aging muscle. FASEB J. 2005;19(3):422-4.

8. Fry CS, Drummond MJ, Glynn EL, Dickinson JM, Gundermann DM, Timmerman KL, et al. Aging impairs contraction-induced human skeletal muscle mTORC1 signaling and protein synthesis. Skelet Muscle. 2011;1(1):11.

9. Volpi E, Ferrando AA, Yeckel CW, Tipton KD, Wolfe RR. Exogenous amino acids stimulate net muscle protein synthesis in the elderly. The Journal of clinical investigation. 1998;101(9):2000-7.

10. Jefferson LS, Rannels DE, Munger BL, Morgan HE. Insulin in the regulation of protein turnover in heart and skeletal muscle. Fed Proc. 1974;33(4):1098-104.

11. Proud CG, Denton RM. Molecular mechanisms for the control of translation by insulin. Biochem J. 1997;328(Pt 2):329-41.

12. Timmerman K, Lee J, Fujita S, Dhanani S, Dreyer H, Fry C, et al. Pharmacological vasodilation improves insulin-stimulated muscle protein anabolism but not glucose utilization in older adults. Diabetes. 2010;59(11):2764-71.

13. Muniyappa R, Montagnani M, Koh KK, Quon MJ. Cardiovascular Actions of Insulin. Endocrine Reviews. 2007;28(5):463-91.

14. Phillips SM. Insulin and muscle protein turnover in humans: stimulatory, permissive, inhibitory, or all of the above? Am J Physiol Endocrinol Metab. 2008;295(4):E731.

15. Trommelen J, Groen B, Hamer H, de Groot LC, van Loon LJ. MECHANISMS IN ENDOCRINOLOGY: Exogenous insulin does not increase muscle protein synthesis rate when administrated systemically: a systematic review. European journal of endocrinology / European Federation of Endocrine Societies. 2015.

16. Greenhaff PL, Karagounis LG, Peirce N, Simpson EJ, Hazell M, Layfield R, et al. Disassociation between the effects of amino acids and insulin on signaling, ubiquitin ligases, and protein turnover in human muscle. Am J Physiol Endocrinol Metab. 2008;295(3):E595-604.

17. Hillier TA, Fryburg DA, Jahn LA, Barrett EJ. Extreme hyperinsulinemia unmasks insulin's effect to stimulate protein synthesis in the human forearm. Am J Physiol. 1998;274(6 Pt 1):E1067-74.

18. Nygren J, Nair KS. Differential regulation of protein dynamics in splanchnic and skeletal muscle beds by insulin and amino acids in healthy human subjects. Diabetes. 2003;52(6):1377-85.

19. Guillet C, Prod'homme M, Balage M, Gachon P, Giraudet C, Morin L, et al. Impaired anabolic response of muscle protein synthesis is associated with S6K1 dysregulation in elderly humans. FASEB J. 2004;18(13):1586-7.

20. Guillet C, Delcourt I, Rance M, Giraudet C, Walrand S, Bedu M, et al. Changes in basal and insulin and amino acid response of whole body and skeletal muscle proteins in obese men. J Clin Endocrinol Metab. 2009;94(8):3044-50. 
21. Smith GI, Atherton P, Reeds DN, Mohammed BS, Jaffery H, Rankin D, et al. No major sex differences in muscle protein synthesis rates in the postabsorptive state and during hyperinsulinemiahyperaminoacidemia in middle-aged adults. J Appl Physiol (1985). 2009;107(4):1308-15.

22. Chevalier S, Goulet ED, Burgos SA, Wykes LJ, Morais JA. Protein anabolic responses to a fed steady state in healthy aging. J Gerontol A Biol Sci Med Sci. 2011;66(6):681-8.

23. Smith GI, Atherton P, Reeds DN, Mohammed BS, Rankin D, Rennie MJ, et al. Omega-3 polyunsaturated fatty acids augment the muscle protein anabolic response to hyperinsulinaemia-hyperaminoacidaemia in healthy young and middle-aged men and women. Clin Sci (Lond). 2011;121(6):267-78.

24. Tessari P, Barazzoni R, Zanetti M. Differences in estimates of forearm protein synthesis between leucine and phenylalanine tracers following unbalanced amino acid infusion. Metabolism. 1999;48(12):1564-9.

25. Toth MJ, LeWinter MM, Ades PA, Matthews DE. Impaired muscle protein anabolic response to insulin and amino acids in heart failure patients: relationship with markers of immune activation. Clin Sci (Lond). 2010;119(11):467-76.

26. Trommelen J, Groen BB, Hamer HM, de Groot LC, van Loon LJ. MECHANISMS IN ENDOCRINOLOGY: Exogenous insulin does not increase muscle protein synthesis rate when administered systemically: a systematic review. Eur J Endocrinol. 2015;173(1):R25-34.

27. Katsanos CS, Kobayashi H, Sheffield-Moore M, Aarsland A, Wolfe RR. Aging is associated with diminished accretion of muscle proteins after the ingestion of a small bolus of essential amino acids. Am J Clin Nutr. 2005;82(5):1065-73.

28. Burd NA, Gorissen SH, van Loon LJ. Anabolic resistance of muscle protein synthesis with aging. Exerc Sport Sci Rev. 2013;41(3):169-73.

29. Burd NA, Wall BT, van Loon LJ. The curious case of anabolic resistance: old wives' tales or new fables? Journal of applied physiology. 2012;112(7):1233-5.

30. Breen L, Phillips SM. Skeletal muscle protein metabolism in the elderly: Interventions to counteract the 'anabolic resistance' of ageing. Nutr Metab (Lond). 2011;8:68.

31. Rennie MJ. Anabolic resistance: the effects of aging, sexual dimorphism, and immobilization on human muscle protein turnover. Appl Physiol Nutr Metab. 2009;34(3):377-81.

32. Timmerman KL, Volpi E. Amino acid metabolism and regulatory effects in aging. Current opinion in clinical nutrition and metabolic care. 2008;11(1):45-9.

33. Rennie MJ, Wilkes EA. Maintenance of the musculoskeletal mass by control of protein turnover: the concept of anabolic resistance and its relevance to the transplant recipient. Ann Transplant. 2005; 10(4):31-4

34. Guillet C, Boirie Y. Insulin resistance: a contributing factor to age-related muscle mass loss? Diabetes \& metabolism. 2005;31 Spec No 2:5S20-5S6.

35. ADA. Diagnosis and classification of diabetes mellitus. Diabetes Care. 2006;29 Suppl 1:S43-8.

36. Jones PR, Pearson J. Anthropometric determination of leg fat and muscle plus bone volumes in young male and female adults. J Physiol. 1969;204(2):63P-6P.

37. van Hall G, Gonzalez-Alonso J, Sacchetti M, Saltin B. Skeletal muscle substrate metabolism during exercise: methodological considerations. The Proceedings of the Nutrition Society. 1999;58(4):899-912.

38. Landsman ML, Kwant G, Mook GA, Zijlstra WG. Light-absorbing properties, stability, and spectral stabilization of indocyanine green. Journal of applied physiology. 1976;40(4):575-83.

39. Fujita S, Glynn EL, Timmerman KL, Rasmussen BB, Volpi E. Supraphysiological hyperinsulinaemia is necessary to stimulate skeletal muscle protein anabolism in older adults: evidence of a true age-related insulin resistance of muscle protein metabolism. Diabetologia. 2009;52(9):1889-98.

40. Bergstrom J. Percutaneous needle biopsy of skeletal muscle in physiological and clinical research. Scand J Clin Lab Invest. 1975;35(7):609-16.

41. Waterval WA, Scheijen JL, Ortmans-Ploemen MM, Habets-van der Poel CD, Bierau J. Quantitative UPLC$\mathrm{MS} / \mathrm{MS}$ analysis of underivatised amino acids in body fluids is a reliable tool for the diagnosis and followup of patients with inborn errors of metabolism. Clinica chimica acta; international journal of clinical chemistry. 2009;407(1-2):36-42.

42. Biolo G, Tessari P, Inchiostro S, Bruttomesso D, Fongher C, Sabadin L, et al. Leucine and phenylalanine kinetics during mixed meal ingestion: a multiple tracer approach. Am J Physiol. 1992;262(4 Pt 1): E455-63. 
43. Koopman R, Crombach N, Gijsen AP, Walrand S, Fauquant J, Kies AK, et al. Ingestion of a protein hydrolysate is accompanied by an accelerated in vivo digestion and absorption rate when compared with its intact protein. Am J Clin Nutr. 2009;90(1):106-15.

44. Wolfe RR. Tracers in metabolic research: radioisotope and stable isotope/mass spectrometry methods. Lab Res Methods Biol Med. 1984;9:1-287.

45. Boirie Y, Gachon P, Corny S, Fauquant J, Maubois JL, Beaufrere B. Acute postprandial changes in leucine metabolism as assessed with an intrinsically labeled milk protein. Am J Physiol. 1996;271(6 Pt 1): E108391.

46. Matthews DE. An overview of phenylalanine and tyrosine kinetics in humans. J Nutr. 2007;137(6 Suppl 1):1549S-55S; discussion 73S-75S.

47. Biolo G, Fleming RY, Maggi SP, Wolfe RR. Transmembrane transport and intracellular kinetics of amino acids in human skeletal muscle. Am J Physiol. 1995;268(1 Pt 1):E75-84.

48. Burd NA, Pennings B, Groen BB, Gijsen AP, Senden JM, van Loon L. The single biopsy approach is reliable for the measurement of muscle protein synthesis rates in vivo in older men. Journal of applied physiology. 2012;113(6):896-902.

49. Polonsky KS, Given BD, Van Cauter E. Twenty-four-hour profiles and pulsatile patterns of insulin secretion in normal and obese subjects. J Clin Invest. 1988;81(2):442-8.

50. Bonadonna RC, Saccomani MP, Cobelli C, DeFronzo RA. Effect of insulin on system A amino acid transport in human skeletal muscle. J Clin Invest. 1993;91(2):514-21.

51. Abdulla H, Smith K, Atherton PJ, Idris I. Role of insulin in the regulation of human skeletal muscle protein synthesis and breakdown: a systematic review and meta-analysis. Diabetologia. 2016;59(1): 44-55.

52. Wall BT, Gorissen SH, Pennings B, Koopman R, Groen BB, Verdijk LB, et al. Aging Is Accompanied by a Blunted Muscle Protein Synthetic Response to Protein Ingestion. PLoS One. 2015;10(11):e0140903.

53. Biolo G, Declan Fleming R, Wolfe R. Physiologic hyperinsulinemia stimulates protein synthesis and enhances transport of selected amino acids in human skeletal muscle. The Journal of clinical investigation. 1995;95(2):811-9.

54. Biolo G, Wolfe RR. Insulin action on protein metabolism. Baillieres Clin Endocrinol Metab. 1993;7(4):9891005 .

55. Bohe J, Low A, Wolfe RR, Rennie MJ. Human muscle protein synthesis is modulated by extracellular, not intramuscular amino acid availability: a dose-response study. J Physiol. 2003;552(Pt 1):315-24.

56. Atherton PJ, Etheridge T, Watt PW, Wilkinson D, Selby A, Rankin D, et al. Muscle full effect after oral protein: time-dependent concordance and discordance between human muscle protein synthesis and mTORC1 signaling. Am J Clin Nutr. 2010;92(5):1080-8.. 


\section{Chapter 4}

Skeletal muscle capillary density and microvascular function are compromised with aging and type 2 diabetes

Bart B.L. Groen, Henrike M. Hamer, Tim Snijders, Janneau van Kranenburg, Dionne Frijns, Hans Vink, and Luc J.C. van Loon

J Appl Physiol (1985). 2014;116:998-1005 


\section{Abstract}

\section{Background}

Adequate muscle perfusion is required for the maintenance of skeletal muscle mass. Impairments in microvascular structure and/or function with aging and type 2 diabetes have been associated with the progressive loss of skeletal muscle mass.

\section{Objective}

To compare muscle fiber type specific capillary density and endothelial function between healthy young, older men and age-matched type 2 diabetes patients.

\section{Design}

15 healthy young men $(24 \pm 1 \mathrm{y}), 15$ healthy older men $(70 \pm 2 \mathrm{y})$, and 15 age-matched type 2 diabetes patients $(70 \pm 1 \mathrm{y})$ were selected to participate in the present study. Whole-body insulin sensitivity, muscle fiber type specific capillary density, sublingual microvascular density and dimension of the erythrocyte perfused boundary region were assessed to evaluate the impact of aging and/or type 2 diabetes on microvascular structure and function.

\section{Results}

Whole body insulin sensitivity was significantly lower at a more advanced age, with lowest values reported in the type 2 diabetic patients. In line, skeletal muscle capillary contacts were much lower in the older and older type 2 diabetic patients when compared with the young. Sidestream darkfield imaging showed a significantly greater thickness of the erythrocyte perfused boundary region in the type 2 diabetic patients compared with the young.

\section{Conclusions}

Skeletal muscle capillary density is reduced with aging and type 2 diabetes and accompanied by impairments in endothelial glycocalyx function, which is indicative of compromised vascular function. 


\section{Introduction}

Aging is associated with the loss of skeletal muscle mass and strength, resulting in functional impairments and an increased risk of developing chronic metabolic diseases. ${ }^{1,2}$ Recent work suggests that with aging, skeletal muscle tissue becomes less sensitive to the main anabolic stimuli, i.e. food intake and physical activity. ${ }^{3-5}$ The proposed blunted muscle protein synthetic response, also known as "anabolic resistance", has been suggested to represent a key factor responsible for the progressive loss of skeletal muscle mass with aging. ${ }^{6}$ Although the cause of this proposed anabolic resistance remains to be established, there is an emerging body of evidence suggesting that the resistance of senescent muscle to the postprandial insulinmediated stimulation of muscle perfusion plays a key role.

Adequate muscle perfusion is essential for muscle mass maintenance, as it determines the rapid postprandial delivery of amino acids, nutrients and growth factors to the muscle, thereby stimulating muscle protein synthesis. ${ }^{7}$ An impaired responsiveness of the skeletal muscle microvasculature to postprandial insulin release may be attributed to impairments in muscle microvascular structure and endothelial function, which may include a decline in capillary density ${ }^{8}$ and structural changes of the endothelial wall. ${ }^{9,10}$ In accordance, several studies have shown that aging has been associated with a lower capillary density of skeletal muscle tissue. ${ }^{11}$ Furthermore, Solomon and colleagues recently demonstrated reduced skeletal muscle capillary density and nitric oxide bioavailability across the glucose tolerance continuum in older obese adults. ${ }^{12}$

Besides changes in microvascular structure, there are also data to indicate that the endothelial wall function is compromised in senescent tissue. ${ }^{9,13}$ In the search for novel targets to assess microvascular function, the recognition of the potential role of the endothelial glycocalyx layer in mediating vascular function offers new and exciting opportunities. Nearly 45 years ago, Luft et al. introduced the endothelial glycocalyx layer as a dynamic intraluminal layer that consists of endothelial cell-derived proteoglycans, glycoproteins and adsorbed plasma proteins. ${ }^{14}$ This network determines vascular permeability, transduces shear stress to the endothelium and modulates interaction of leukocytes and thrombocytes with the vascular wall. ${ }^{15}$ Prior work has shown that glycocalyx permeability assessed in the sublingual cavity is representative of generic impairments in endothelial function in various other tissues in a large variety of subject populations. ${ }^{16-20}$ As such, endothelial glycocalyx thickness in the oral cavity has been shown to correlate with impairments in endothelial function in the liver, ${ }^{19}$ brain $^{17}$ and kidney. ${ }^{18}$ Diabetes mellitus is associated with both microvascular and macrovascular diseases affecting numerous organs, including skeletal muscle, skin, heart, brain, and kidneys. ${ }^{21}$ Diabetes-associated vascular alterations include anatomic, structural, and functional changes leading to multi organ dysfunction. ${ }^{22}$ Besides 
vascular alterations, it has also been reported that elderly type 2 diabetes patients show a more pronounced decline in skeletal muscle mass when compared with agematched normoglycemic controls. ${ }^{23}$ Hence, it has been proposed that the loss of skeletal muscle mass represents not only a cause, but also a consequence of type 2 diabetes. ${ }^{24}$ Therefore, we hypothesize that the vascular density and the endothelial glycocalyx layer are even more compromised in the older population with type 2 diabetes.

The present study investigates the impact of both aging and type 2 diabetes on skeletal muscle capillary density as well as microvascular function. Therefore, we selected 15 healthy young (age: $24 \pm 1$ y) and 15 older (age: $70 \pm 2$ y) males, as well as 15 agematched older type 2 diabetic patients (age: $70 \pm 1$ y). An oral glucose tolerance test was applied to assess whole-body glucose tolerance and insulin sensitivity, muscle biopsies were collected to assess skeletal muscle fiber type specific capillary density. Sidestream darkfield (SDF) imaging was used to assess capillary density and endothelial glycocalyx layer characteristics as a marker for endothelial microvascular function.

\section{Methods}

\section{Subjects}

15 healthy young men, 15 healthy older men and 15 age and BMI matched type 2 diabetes patients were selected to participate in this study. Exclusion criteria were impaired renal or liver function, obesity $\left(\mathrm{BMl}>30 \mathrm{~kg} \cdot \mathrm{m}^{-2}\right)$, glycosylated hemoglobin $\left(\mathrm{HbA}_{1 \mathrm{c}}\right)$ content $>10.0 \%$, cardiac disease, hypertension, diabetes complications, and exogenous insulin therapy. All type 2 diabetic patients were prescribed with oral blood glucose-lowering medication (metformin $(n=8)$, sulfonylurea derivatives $(n=2)$, metformin in combination with sulfonylurea $(n=4)$ or metformin in combination with a DPP-4 inhibitor $(n=1))$.

\section{Ethics Statement}

After explanation of the study protocol and potential risks and benefits, all subjects provided written informed consent before participating in the study. This study was approved by the Medical Ethical Committee of the academic hospital Maastricht and conform the principles outlined in the Declaration of Helsinki for use of human subjects and tissue. 


\section{Experimental protocol}

Baseline characteristics (age, weight, height, blood pressure, leg volume, physical activity level (PAL) index ${ }^{25}$ were determined in all subjects prior to inclusion in the study protocol. Thereafter, various measurements were performed in two visits: a CT scan to assess muscle cross sectional area $15 \mathrm{~cm}$ above the patella from the dominant leg, an oral glucose tolerance test, sidestream darkfield (SDF) imaging of the oral cavity, and a muscle biopsy collection procedure.

\section{Oral glucose tolerance test}

Two days prior to the oral glucose tolerance test (OGTT), subjects were instructed to refrain from intense physical activity, alcohol and coffee. In addition, type 2 diabetes patients discontinued anti-diabetic medication two days prior to the OGTT. The subjects resumed the use of their prescribed medication after the test. All subjects consumed a standardized dinner the evening prior to the test containing $0.18 \mathrm{MJ} \cdot \mathrm{kg}^{-1}$ body weight, consisting of 55 energy percent (En\%) carbohydrate, 15 En\% protein and $30 \mathrm{En} \%$ fat. After $22.00 \mathrm{~h}$, the subjects were allowed only water ad libitum until the beginning of the experiments. Following an overnight fast, the subjects arrived at the laboratory at $08.00 \mathrm{~h}$ in the morning of the test day by car or public transportation. A catheter (Baxter BV, Utrecht, the Netherlands) was inserted into an antecubital vein for venous blood sampling. After insertion of the catheter, subjects were asked to stay in a supine position for the remainder of the test. After collection of a basal blood sample, subjects ingested a standard glucose drink (82.5 g dextrose monohydrate (AVEBE, Veendam, The Netherlands) in $250 \mathrm{~mL}$ water). Subsequent blood samples were collected at $\mathrm{t}=30,60,90$ and $120 \mathrm{~min}$. Aliquots of plasma were frozen in liquid nitrogen and stored at $-80^{\circ} \mathrm{C}$ until analyses. Plasma glucose concentrations were analyzed with the automatic analyzer ABX Pentra 400 (Horiba ABX Diagnostics, Kyoto, Japan) with an ABX Pentra Glucose HK CP Kit (A11A01667, Horiba ABX Diagnostics). Plasma insulin was determined by radio immunoassay (Human Insulin RIA (HI-14K, Millipore, Massachusetts, USA). To determine $\mathrm{HbA}_{1 \mathrm{c}}$ content, a 3-mL blood sample was collected in EDTA-containing tube and analyzed by high-performance liquid chromatography (Bio-Rad Diamat, Munich, Germany). Venous plasma glucose and insulin concentrations obtained during the OGTT were used to assess pancreatic $\beta$-cell function and insulin sensitivity. These parameters were assessed using the updated homeostasis model assessment HOMA, and the oral glucose insulin sensitivity (OGIS)-index, respectively. ${ }^{26}$

\section{SDF imaging}

Visualization of the sublingual microvascular system was performed with sidestream dark-field (SDF) imaging, and has been described in detail elsewhere. ${ }^{17,20}$ Perfused blood vessels with a diameter ranging from 1-50 $\mu \mathrm{m}$ can be visualized, thereby covering the average capillary diameter that ranges around $10 \mu \mathrm{m}$. Covered by a disposable cap, 
the probe of the camera can be placed on tissue surface. For this purpose SDF measurements were taken in de oral cavity underneath the tongue, since this area is easily accessible and is considered as a valid derivative to assess microvascular function in other tissues. ${ }^{16-18}$ By placing the probe under the tongue, images of the sublingual microcirculation are obtained. ${ }^{27}$ The SDF recordings using the hand held SDF camera (MicroScan Microscope System; Micro Vision Medical, Microscan B.V. Amsterdam, The Netherlands) were made prior to the OGTT. Recordings of the sublingual microcirculation were taken at 3 different sites under the tongue per time point and all recordings were taken by the same researcher.

Using the images from the SDF camera, microcirculatory parameters were measured. The recordings were analyzed with dedicated software (Glycocheck ICU, Glycocheck B.V., Maastricht, The Netherlands) to determine the number of capillaries per diameter class per square millimeter. Permeability of the endothelial glycocalyx wall, also referred to as the perfused boundary region (PBR), was determined as described previously ${ }^{28}$ and illustrated in Figure 4.1. In each subject, GlycoCheck ICU analyzing software automatically measured the red blood cell (RBC) column in at least 3,000 vessel segments. For each measurement segment, 840 radial intensity profiles were obtained for measurement of RBC column width, and PBR was calculated as distance of median ( $\left.P_{50}\right)$ RBC column width to the (estimated) outer edge of the RBC-perfused lumen (Figure 4.1). Vessel segments were classified in 1- $\mu \mathrm{m}$-wide diameter classes and median PBR values were determined for each diameter class before calculating the average PBR over the 5- to $25-\mu \mathrm{m}$ diameter range.

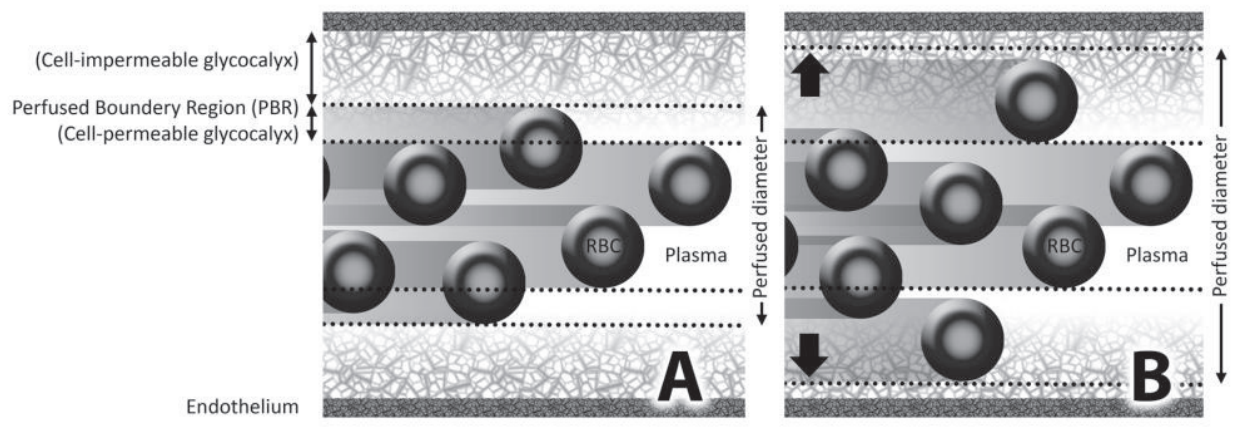

Figure 4.1 Schematic representation of a normal (A) and impaired (B) endothelial glycocalyx layer (figure not drawn to scale). Red blood cells (RBC) in blood plasma penetrate the cell-permeable glycocalyx layer. The erythrocyte perfused boundary region (PBR) was calculated as distance of median ( $\left.P_{50}\right)$ RBC column width to the (estimated) outer edge of the RBC-perfused lumen. The perfused diameter depends on the depth of RBC penetration in the glycocalyx. Increased penetration of the RBC into the glycocalyx layer, measured as an increased PBR (B), illustrates an increased permeability of the endothelial glycocalyx layer. 


\section{Immunohistochemical analyses}

A muscle tissue biopsy was obtained from all subjects to determine muscle fiber characteristics and vascularization. A percutaneous needle biopsy $(50-80 \mathrm{mg})$ was taken from the middle region of the $m$. vastus lateralis muscle, $15 \mathrm{~cm}$ above the patella and approximately $2 \mathrm{~cm}$ away from the fascia. Muscle biopsies were carefully freed from any visible fat and blood, after which the tissue was embedded in Tissue-Tek and rapidly frozen in liquid nitrogen cooled isopentane (Sakura Finetek Europe BV, The Netherlands). Muscle biopsies were stored at $-80^{\circ} \mathrm{C}$ for subsequent immunohistochemical analysis.

From all muscle biopsies, $5 \mu \mathrm{m}$-thick cryosections were cut at $-20^{\circ} \mathrm{C}$. Samples of a young, elderly and type 2 diabetes patient were mounted together on uncoated glass slides. Care was taken to properly align the samples for cross-sectional fiber analyses. Serial cross-sections were stained simultaneously for muscle fiber type and capillaries. First used antibodies are directed against myosin heavy chain (MHC)-I (A4.840, dilution 1:25; Developmental Studies Hybridoma Bank, lowa City, IA), laminin (polyclonal rabbit anti-laminin, dilution 1:50; Sigma, Zwijndrecht, the Netherlands), and CD31 (dilution 1:50; DAKO, Glostrup, Denmark). The latter antibody was used for capillary determination in human muscle tissue. ${ }^{29}$ Appropriate secondary antibodies were applied: goat anti-mouse IgM AlexaFluor488, goat anti-rabbit IgG AlexaFluor350 (dilution 1:500 and 1:200, respectively; Molecular Probes, Invitrogen, Breda, the Netherlands) and Biotine + Avidin-D Texas Red (dilution 1:133 and 1:200, respectively; Vector Laboratories, Inc., Burlingame, CA).

Staining procedures were as follows: after 5 min fixation in acetone, the slides were air dried and incubated for $45 \mathrm{~min}$ at room temperature with CD31 primary antibodies directed against Platelet Endothelial Cell Adhesion Molecule-1 diluted in 0.05\% TweenPhosphate buffered saline (PBS). For optimizing the staining result, slides were first incubated for 60 min with Biotinylated horse anti-mouse IgG (dilution 1:150; Vector Laboratories, Inc.), diluted in $0.05 \%$ Tween-PBS. Slides were then washed $(3 \times 5$ min PBS). Thereafter, slides were incubated for $60 \mathrm{~min}$ at room temperature with Avidin-D Texas Red diluted in $0.05 \%$ Tween-PBS. After another washing step with PBS, slides were incubated for $45 \mathrm{~min}$ with the primary antibodies directed against laminin and MHC-I diluted in $0.05 \%$ Tween-PBS. Subsequently, slides were incubated for $30 \mathrm{~min}$ at room temperature with the appropriate secondary antibodies in $0.05 \%$ Tween-PBS. After a final washing step, all slides were mounted with cover glasses using Mowiol (Calbiochem, Amsterdam, The Netherlands). Staining procedures resulted in laminin stained in blue, MHC-I in green and CD31 in red (Figure 4.2). All images were digitally captured, using fluorescence microscopy with a Nikon E800 fluorescence microscope (Nikon Instruments Europe, Badhoevedorp, The Netherlands) coupled to a Basler A113 C progressive scan color CCD camera with a Bayer color filter. Epifluorescence signal was recorded using a Texas Red excitation filter $(540-580 \mathrm{~nm})$ for CD31, a DAPI UV excitation filter (340-380 nm) for laminin, and a fluorescein isothiocyanate excitation 
filter (465-495 nm) for MHC-I. From the slides, images were captured at a 120x magnification. Laminin was used to determine the basement membrane, and all fibers within each image were identified as Type I or Type II fiber. Image processing and quantitative analyses were done using Lucia 4.81 software package (Nikon). Capillaries were quantified manually on each fiber to estimate the following indexes: the number of capillaries around a fiber (capillary contacts (CC)), fiber area (FA), perimeter (P) and the capillary-to-fiber ratio on an individual-fiber basis $\left(C / F_{i}\right)$, as described elsewhere. ${ }^{30}$ To examine the potential for blood-tissue exchange, the capillary-to-fiber perimeter exchange (CFPE) index ${ }^{31}$ was calculated. All images recordings and analyses were performed by an investigator blinded to participant coding.

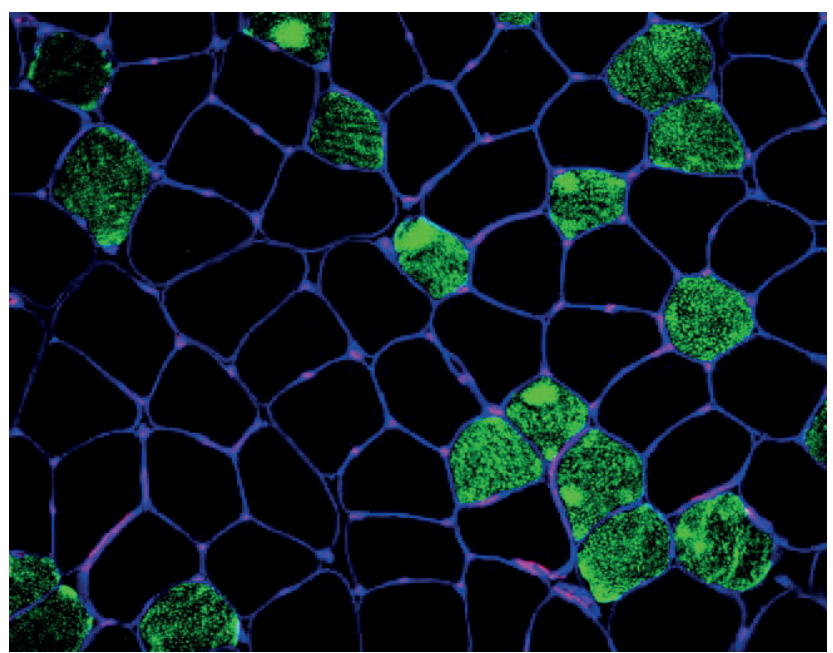

Figure 4.2 Representation of fiber-type-specific analysis of skeletal muscle microvascular straining. Type I muscle cells are shown in green (MHC-1), type II muscle cells in black, cell walls in blue (laminin) and micro vessels in red (CD-31).

\section{Statistics}

Data are presented as means \pm SE and statistical analyses were performed using SPSS version 21 (SPSS Inc., Chicago, USA). Differences between groups were determined by one-way analysis of variance (ANOVA). When a significant difference was found, pair wise comparisons by a Bonferroni post-hoc test were used to assess differences. Fiber type specific results were analyzed by a two-way repeated measures ANOVA, with fiber type (type I vs. II) as within subject factor and group (young vs. older vs. type 2 diabetic patients) as between subject factor. When a significant difference was found, pair wise comparisons by a Bonferroni post-hoc test were used to assess differences. 
Correlations between different parameters were calculated using Pearson's productmoment correlations. For all comparisons significance was recognized at $P<0.05$.

\section{Results}

\section{Subjects}

Subjects' characteristics of the three groups (young, older and type 2 diabetic patients) are shown in Table 4.1. All subjects completed the study protocol and no adverse events were reported. Young subjects were significantly different from older and type 2 diabetic patients in age, BMI, HbA1c, 2 h glucose (OGTT), area under the curve for plasma glucose and insulin concentrations during OGTT, OGIS, systolic and diastolic blood pressure. Significant differences between older and type 2 diabetic patients were seen in HbA1c, basal plasma glucose levels, 2 h glucose (OGTT), area under the curve for OGTT, OGIS and HOMA-IR. Leg volume and physical activity levels did not differ between groups.

Table 4.1 Subjects' characteristics.

\begin{tabular}{|c|c|c|c|}
\hline & $\begin{array}{l}\text { Young } \\
(n=15)\end{array}$ & $\begin{array}{c}\text { Older } \\
(n=15)\end{array}$ & $\begin{array}{c}\text { Type } 2 \text { diabetes } \\
(n=15)\end{array}$ \\
\hline Age (y) & $24 \pm 1$ & $70 \pm 2 *$ & $70 \pm 1 *$ \\
\hline Weight (kg) & $77.2 \pm 2.3$ & $82.8 \pm 2.3$ & $86.2 \pm 2.9 *$ \\
\hline Body mass index $\left(\mathrm{kg} / \mathrm{m}^{2}\right)$ & $23.2 \pm 0.6$ & $26.6 \pm 0.5 *$ & $27.4 \pm 0.6 *$ \\
\hline Leg volume (L) & $8.0 \pm 0.2$ & $8.2 \pm 0.4$ & $7.7 \pm 0.3$ \\
\hline $\mathrm{HbA1c}(\%)$ & $5.2 \pm 0.1$ & $5.6 \pm 0.1 *$ & $6.6 \pm 0.2 * \Delta$ \\
\hline Fasting glucose (mmol/L) & $5.0 \pm 0.1$ & $5.4 \pm 0.1$ & $7.8 \pm 0.4 * \Delta$ \\
\hline $2 \mathrm{~h}$ glucose (OGTT) (mmol/L) & $4.9 \pm 0.3$ & $6.6 \pm 0.5 *$ & $15.3 \pm 1.1 * \Delta$ \\
\hline OGTT AUC glucose (mmol/L/2h) & $718 \pm 29$ & $933 \pm 53 *$ & $1636 \pm 86 * \Delta$ \\
\hline Fasting insulin (mU/L) & $14.6 \pm 0.2$ & $21.3 \pm 3.1$ & $24.5 \pm 3.3^{*}$ \\
\hline $2 \mathrm{~h}$ insulin (OGTT) (mU/L) & $31 \pm 4$ & $61 \pm 8 *$ & $70 \pm 8 *$ \\
\hline OGTT AUC insulin (U/L/2h) & $5263 \pm 340$ & $10570 \pm 1567 *$ & $6806 \pm 612$ \\
\hline HOMA-IR & $3.27 \pm 0.34$ & $5.83 \pm 0.82$ & $7.30 \pm 0.88 * \Delta$ \\
\hline OGIS & $443 \pm 13$ & $364 \pm 14 *$ & $291 \pm 10 * \Delta$ \\
\hline Systolic blood pressure (mmHg) & $125 \pm 2$ & $133 \pm 3^{*}$ & $134 \pm 4^{*}$ \\
\hline Diastolic blood pressure $(\mathrm{mmHg})$ & $66 \pm 2$ & $74 \pm 2 *$ & $74 \pm 3 *$ \\
\hline PAL index & $1.44 \pm 0.03$ & $1.52 \pm 0.04$ & $1.39 \pm 0.07$ \\
\hline
\end{tabular}

Values represent means $\pm \mathrm{SE}$. $\mathrm{HbA}_{1 c}$, glycated hemoglobin; OGTT, oral-glucose-tolerance test; OGTT 120, plasma glucose concentrations 120 min after ingesting a 75g glucose load; HOMA-IR, Homeostasis Model of Assessment - Insulin Resistance; OGIS Oral Glucose Insulin Sensitivity; PAL index, physical activity level. Analysis of variance (ANOVA) was used for statistical analysis of the data, using Bonferroni post hoc testing. * Significantly different from young, $P<0.05$. ${ }^{\Delta}$ Significantly different from the older healthy subjects, $P<0.05$. 


\section{Muscle characteristics}

Cross-sectional area of the quadriceps upper leg muscles was determined with a single slice CT scan from both legs. Cross sectional area (Table 4.2) was significantly lower in the older $(-16 \%)$ and type 2 diabetic patients $(-20 \%)$ when compared to the young $(P<0.05$ and $P<0.01$, respectively). Fiber area was analyzed in the muscle biopsy stainings from the vastus lateralis muscle (Figure 4.2). One-way ANOVA showed significant differences in mixed muscle fiber area between groups, with fiber area being significantly lower in the type 2 diabetic patients when compared to the young $(P=0.007)$. No significant differences were observed between muscle fiber types (effect of fiber type $P=0.410$ ). Both type I and type II muscle fiber size in the type 2 diabetic patients were significantly smaller when compared to the young $(P=0.009)$. Furthermore, a strong tendency for a 'fiber type $x$ group' interaction $(P=0.071)$ was observed implying some level of fiber type specificity in the observed differences in muscle fiber type size between groups.

Table 4.2 Muscle and fiber characteristics.

\begin{tabular}{|c|c|c|c|c|}
\hline & Fiber & $\begin{array}{l}\text { Young } \\
(n=15) \\
\end{array}$ & $\begin{array}{l}\text { Older } \\
(n=15)\end{array}$ & $\begin{array}{c}\text { Type } 2 \text { diabetes } \\
(n=15)\end{array}$ \\
\hline Quadriceps muscle CSA $\left(\mathrm{cm}^{2}\right)$ & & $84.0 \pm 3.6$ & $71.0 \pm 2.8^{*}$ & $67.6 \pm 6.5 *$ \\
\hline \multirow[t]{3}{*}{ Fiber area $\left(\mu \mathrm{m}^{2}\right)$} & Mixed & $7172 \pm 432$ & $6303 \pm 311$ & $5616 \pm 259 *$ \\
\hline & Type I & $6660 \pm 522$ & $6533 \pm 386$ & $5558 \pm 275^{*}$ \\
\hline & Type II & $7570 \pm 478$ & $6107 \pm 354$ & $5649 \pm 315^{*}$ \\
\hline
\end{tabular}

Values represent means \pm SE. Quadriceps muscle CSA, cross sectional area. Differences between groups (quadriceps muscle CSA and mixed muscle fiber area) were determined by one-way analysis of variance (ANOVA) and pair wise comparisons by Bonferroni post-hoc testing were used to assess where significant differences were located. Fiber type specific results were determined by a two-way repeated measures ANOVA, with fiber type (type I vs type II) as within subject factor and group (young vs older vs type 2 diabetic patients) as between subjects factor. * Significantly different from the young (Bonferroni post hoc test, $P<0.05)$.

\section{Microvascular density in muscle biopsy stainings}

Muscle characteristics for microvascular density were analyzed in muscle biopsies from the vastus lateralis muscle. Morphometric results (i.e. capillary contacts, individual capillary-to-fiber ratio, and CFPE-index) are presented in Table 4.3. All data are provided for mixed muscle, as well as for type I and type II muscle fibers separately. In the mixed muscle tissue, both the older and type 2 diabetic patients show fewer capillary contacts and a lower individual capillary-to-fiber ratio compared to the young ( $P<0.05$ for the older and $P<0.01$ for the type 2 diabetic patients for both parameters, respectively). No differences were observed for CFPE-indices between groups. With respect to fiber type specific capillarization parameters in the muscle biopsies, no fiber type $x$ group interactions were observed. With respect to fiber type, all groups show fewer capillary contacts, lower individual capillary-to-fiber ratio and CFPE-indices in 
type II compared to type I muscle fibers. Looking at fiber type specific differences, only capillary contacts and individual capillary-to-fiber ratio differed between the older and type 2 diabetic patients compared with the young.

Table 4.3 Muscle fiber type specific capillarity.

\begin{tabular}{lcccc}
\hline & Fiber & $\begin{array}{c}\text { Young } \\
(n=15)\end{array}$ & $\begin{array}{c}\text { Older } \\
(n=15)\end{array}$ & $\begin{array}{c}\text { Type 2 diabetes } \\
(n=15)\end{array}$ \\
\hline Capillary contacts & Mixed & $4.68 \pm 0.15$ & $3.98 \pm 0.16^{*}$ & $3.61 \pm 0.24^{*}$ \\
& Type I & $4.89 \pm 0.20$ & $4.29 \pm 0.16^{*}$ & $3.85 \pm 0.24^{*}$ \\
& Type II & $4.41 \pm 0.13^{\#}$ & $3.73 \pm 0.17^{* \#}$ & $3.40 \pm 0.25^{* \#}$ \\
& Mixed & $1.85 \pm 0.07$ & $1.55 \pm 0.06^{*}$ & $1.41 \pm 0.10^{*}$ \\
& Type I & $1.96 \pm 0.10$ & $1.68 \pm 0.06^{*}$ & $1.53 \pm 0.10^{*}$ \\
CFPE index, capillaries/1,000 $\mu \mathrm{m}$ & Type II & $1.73 \pm 0.05^{\#}$ & $1.44 \pm 0.07^{* \#}$ & $1.31 \pm 0.10^{* \#}$ \\
& Mixed & $5.55 \pm 0.22$ & $4.79 \pm 0.19$ & $4.60 \pm 0.26^{*}$ \\
& Type I & $6.07 \pm 0.22$ & $5.17 \pm 0.20$ & $5.02 \pm 0.25^{*}$ \\
& Type II & $5.03 \pm 0.22^{\#}$ & $4.50 \pm 0.18^{\#}$ & $4.27 \pm 0.27^{* \#}$ \\
\hline
\end{tabular}

Values represent means \pm SE. Capillary contacts (CC) represent the number of capillaries in contact with a muscle fiber. Individual capillary-to-fiber ratio $\left(C / F_{i}\right)$ is the proportional number of capillary contacts, in contact with one single muscle cell. CFPE-index is defined as $\left(C / F_{i}\right) / P$, which is the proportional number of capillary contacts divided by the perimeter (21). Differences between groups for mixed muscle fibers were determined by one-way analysis of variance (ANOVA). Fiber type specific results were determined using a two-way repeated measures ANOVA, with fiber type (type I vs type II) as within subject factor and group (young vs older vs type 2 diabetic patients) as between subjects factor. Pair wise comparisons by Bonferroni post-hoc testing were used to locate individual differences $(P<0.05) .{ }^{*}$ significantly different from young;

\# type II significantly different from type I.

\section{Microvascular density in SDF imaging}

Vessels with a diameter ranging from 1 to $50 \mu \mathrm{m}$ were detected in the oral cavity using SDF imaging. Microvascular density was determined by calculating the total number of capillaries per square millimeter. Microvascular density was similar between groups. The relative number of small capillaries per square millimeter, expressed as the percentage small capillaries in relation to the total number is shown in Figure 4.3. The inlay in this figure shows the percentage capillaries with a diameter between 1 and 7 $\mu \mathrm{m}$ (small) versus the percentage capillaries with a diameter ranging from 8 till $50 \mu \mathrm{m}$ (large). A significant difference was only observed between young and type 2 diabetic patients $(P=0.003)$.

\section{Endothelial glycocalyx}

Endothelial glycocalyx permeability, expressed as the thickness of the erythrocyte perfused boundary region (PBR), was measured with SDF imaging. Average values of the groups were calculated with the use of capillaries identified with a diameter between 1 and $50 \mu \mathrm{m}$ (Figure 4.4). On average, PBR was greater in the type 2 diabetic patients when compared with the young controls ( $2.00 \pm 0.05$ vs. $1.79 \pm 0.04 \mu \mathrm{m}, P<0.05)$. 
No significant differences were observed between the young and older. Significant correlations were observed between the PBR thickness and $\mathrm{HbA}_{1 \mathrm{c}}$ levels and $\mathrm{OGIS}$ values $(0.36(P<0.05)$ and $-0.36(P<0.05)$, respectively), suggesting an association between the level of insulin sensitivity and the endothelial glycocalyx thickness. Likewise, a significant correlation was observed between the PBR thickness and muscle cross sectional area $(r=0.57 ; P<0.01)$ and the proportion of small capillaries $(r=-0.39$; $P<0.01)$.

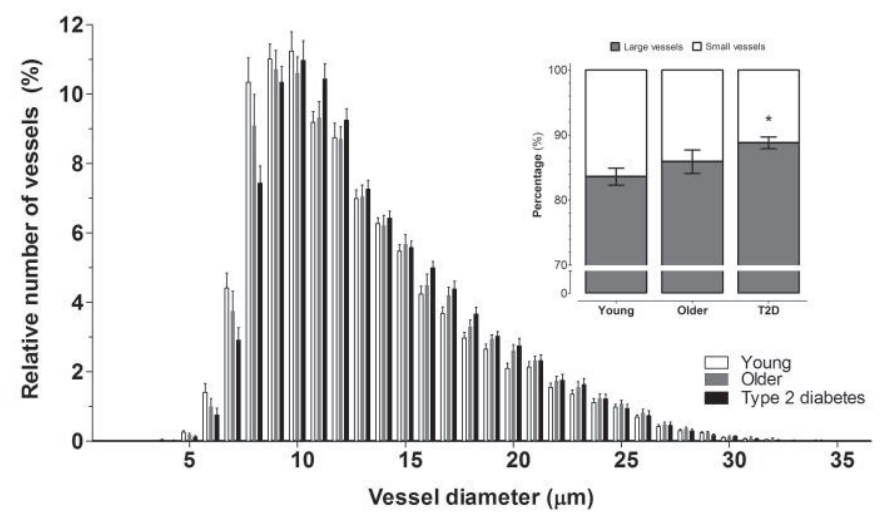

Figure 4.3 Relative number of vessels (expressed as percentage) per vessel diameter. Values are expressed as means $\pm \mathrm{SE}$.

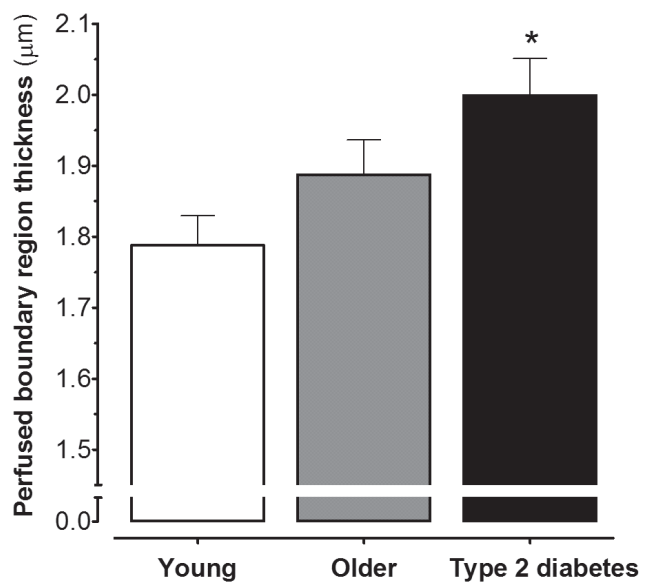

Figure 4.4 Mean perfused boundary region in young, older and older type 2 diabetic patients. Values are expressed as means \pm SE; data were analyzed with one-way ANOVA. * Significantly different from young (Bonferroni's post hoc test, $\mathrm{P}<0.05$ ). 


\section{Discussion}

The present study confirms reduced muscle mass and lower insulin sensitivity in healthy older men and age-matched type 2 diabetic patients when compared with young controls. The greater insulin resistance at a more advanced age was accompanied by a lower capillary density in skeletal muscle tissue and an increased permeability of the endothelial glycocalyx layer.

In agreement with earlier research, ${ }^{12,23}$, we show that insulin sensitivity (OGIS and HOMA-IR) is reduced in both healthy as well as type 2 diabetic older adults when compared with healthy young controls. Similar observations were made for skeletal muscle mass, with significantly less skeletal muscle tissue in the healthy and type 2 diabetic older men when compared with the younger controls (Table 4.2). These results are in line with earlier findings from our lab ${ }^{32}$ as well as others, ${ }^{33-36}$ showing muscle loss with aging, and an even more rapid muscle loss in a clinically compromised type 2 diabetic elderly subpopulation. ${ }^{24}$ Besides assessing muscle mass on a macroscopic scale, we performed additional microscopic analyses to assess various muscle fiber type characteristics (Table 4.2 and 4.3). In agreement with previous work from our group ${ }^{37,38}$ as well as others, ${ }^{39}$ we observed that muscle fiber size was reduced in the older and older type 2 diabetic men when compared with the young controls. In addition, muscle fiber size tended to be smaller in the type 2 diabetic patients when compared with the age-matched healthy controls. Differences in muscle fiber size between groups seemed to be particularly evident for the type II muscle fibers. In line, we observed a strong tendency for a fiber type $x$ group interaction $(P=0.071)$, suggesting that type II fibers are more prone to muscle atrophy in the older and/or older type 2 diabetes patients.

The reduced muscle mass in the older populations have been, at least partly, attributed to a reduced sensitivity of the muscle protein synthetic machinery to the anabolic response to dietary protein consumption. ${ }^{6,40}$ Underlying mechanisms responsible for this so-called anabolic resistance include impairments in (micro) vascular function and subsequent attenuated increase in postprandial perfusion, ${ }^{13,41,42}$. Impairments in microvascular function may be attributed to a lower capillary density ${ }^{8,43}$ and/or impairments in endothelial wall function. ${ }^{44}$ An intact glycocalyx is required to allow trans-capillary distribution of insulin into the interstitial fluid, thereby allowing associated myocellular signaling, subsequent amino acid uptake, and myofibrillar protein synthesis. In agreement with previous work in various groups, a thicker perfused boundary region is associated with endothelial dysfunction as observed in various organs in multiple patient groups. ${ }^{16,19,45-47}$ In line with these findings we report a thicker perfused boundary region in the type 2 diabetic versus the young. The greater PBR is accompanied by a reduced endothelial glycocalyx thickness, compromising nutrient exchange over the endothelium. We propose that a compromised nutrient 
exchange in the postprandial state in the older and/or type 2 diabetic patient may contribute substantially to the anabolic resistance to feeding and, as such, may be one of the underlying mechanisms responsible for the loss of muscle mass with aging (and 'accelerated' aging in the older type 2 diabetes patient). In the present study we compare muscle mass and muscle fiber type characteristics with several parameters of microvascular function including muscle capillary density, as well as the thickness of the endothelial glycocalyx layer in healthy young, older and older type 2 diabetic patients. This observational study is the first to combine various quantitative and qualitative assessment of microvascular characteristics of muscle tissue.

In the muscle biopsy samples, we quantified microvascular perfusion capacity according to the method of Hepple and colleagues. ${ }^{30}$ Fewer capillary-to-fiber contacts and a smaller ratio between capillaries and the number of muscle fibers they perfuse were observed in the older and older type 2 diabetes patients. Consequently, aging and insulin resistance seem to be accompanied by a structural reduction in perfusion capacity, thereby reducing the potential for amino acid delivery to the muscle. In addition to the muscle biopsy analysis, sidestream darkfield (SDF) imaging was applied to visualize real-time perfusion of the sublingual microvasculature. Using SDF imaging, capillaries with a diameter range between 1 and $50 \mu \mathrm{m}$ were visualized. Currently this method cannot be applied in human leg muscle tissue for in vivo measurements of muscle perfusion, but previous work has shown that these measurements are representative for many other tissues such as liver, brain and kidney. ${ }^{17-19}$ Smaller capillaries tended to be less prevalent in the older and older type 2 diabetes patients when compared with the healthy young controls (Figure 4.3). The observation of a lower capillary density in leg muscle tissue in the older and older type 2 diabetes patients seems to agree with the apparent loss of well perfused small nutritive capillaries visualized with SDF imaging. The capillary loss seems to occur without concomitant arteriolar/venular loss in the old and diabetics (inlay Figure 4.3).

The main reason to apply SDF imaging in the present study was to assess some of the qualitative aspects of the microcirculation in the young, older and older type 2 diabetic patients. The endothelial glycocalyx layer is increasingly being recognized for its important function in the transport capacity (i.e. glucose and/or insulin) over the endothelial wall. ${ }^{28,48}$ Eskens and colleagues ${ }^{28}$ have demonstrated that the loss of endothelial glycocalyx results in elevated permeability of the endothelial layer, thereby compromising protective function and transport capacity over the endothelium. In the present study we show that the endothelial glycocalyx was more compromised in older type 2 diabetes patients when compared to the healthy young controls (Figure 4.1 and 4.4). In the healthy young subjects we observed an average perfused boundary region thickness of $1.79 \pm 0.04 \mu \mathrm{m}$, which is similar to previously reported values in healthy young subjects (18-40 y). ${ }^{49}$ An increased perfused boundary region, reflecting deeper 
penetration of red cells into the luminal part of the endothelial glycocalyx, was observed in the older $(1.89 \pm 0.05 \mu \mathrm{m})$ and the older type 2 diabetic patients $(2.00 \pm 0.05 \mu \mathrm{m})$ compared with healthy young subjects. To the best of our knowledge, this is the first report of a direct comparison of the endothelial glycocalyx layer between young, older and older age matched type 2 diabetic patients. Furthermore, we show that the thickness of the perfused boundary region correlates well with both the OGIS and $\mathrm{HbA}_{1}$ values taken as a measure for insulin resistance $\left(r^{2}=0.36 ; P<0.05\right)$. These correlations strongly support our hypothesis that the integrity of the endothelial glycocalyx layer interacts with the degree of insulin sensitivity and glucose uptake during an OGTT (Table 4.1).

Previously, Broekhuizen et $a .^{50}$ and Nieuwdorp et $a .^{51}$ showed that hyperglycemia is accompanied with changes in glycocalyx characteristics. With the present data we extend on these observations by showing that diabetes and hyperglycemia are associated with loss of muscle mass, lower microvascular density and increased endothelial glycocalyx permeability. It has recently been suggested ${ }^{52}$ that impaired tissue perfusion due to abnormality of the microvascular system is present along with other more conventional cardiovascular risk factors, including hypertension and diabetes. ${ }^{53-55}$ However, the pathologic processes involved in the vascular dysfunction in diabetes are complex and far from being understood. Loss of glycocalyx function may be a common factor in the established relationship between insulin resistance and endothelial dysfunction in patient populations. Furthermore, the results from the present study imply that such microvascular complications may also play a key role in the etiology of anabolic resistance and the associated loss of skeletal muscle mass. Therefore, improving microvascular perfusion and glycocalyx integrity could represent new potential targets to prevent or decrease muscle loss and support healthy aging.

We conclude that aging and type 2 diabetes are accompanied with a reduced muscle mass, lower insulin sensitivity, reduced skeletal muscle capillary density, and compromised endothelial wall function. These observations indicate that both quantitative and qualitative changes in the microvasculature may contribute to the loss of skeletal muscle mass and the development of insulin resistance at a more advanced age. 


\section{References}

1. Janssen I, Heymsfield SB, and Ross R. Low relative skeletal muscle mass (sarcopenia) in older persons is associated with functional impairment and physical disability. J Am Geriatr Soc 2002;50:889-96.

2. Koopman R, and van Loon LJ. Aging, exercise, and muscle protein metabolism. J Appl Physiol 2009;106: 2040-8.

3. Katsanos CS, Kobayashi H, Sheffield-Moore M, Aarsland A, and Wolfe RR. Aging is associated with diminished accretion of muscle proteins after the ingestion of a small bolus of essential amino acids. Am J Clin Nutr 2005;82:1065-73.

4. Phillips B, Williams J, Atherton PJ, Smith K, Hildebrandt W, Rankin D, Greenhaff PL, Macdonald IA, and Rennie M. Resistance exercise training improves age-related declines in leg vascular conductance and rejuvenates acute leg blood flow responses to feeding and exercise. J Appl Physiol (1985). 2012;112:347-53.

5. Walrand S, Short KR, Bigelow ML, Sweatt AJ, Hutson SM, and Nair KS. Functional impact of high protein intake on healthy elderly people. Am J Physiol Endocrinol Metab 2008;295:E921-8.

6. Burd NA, Wall BT, and van Loon LJ. The curious case of anabolic resistance: old wives' tales or new fables? Journal of applied physiology 2012;112:1233-5.

7. Timmerman KL, Lee JL, Dreyer HC, Dhanani S, Glynn EL, Fry CS, Drummond MJ, Sheffield-Moore M, Rasmussen BB, and Volpi E. Insulin stimulates human skeletal muscle protein synthesis via an indirect mechanism involving endothelial-dependent vasodilation and mammalian target of rapamycin complex 1 signaling. J Clin Endocrinol Metab 2010;95:3848-57.

8. Lillioja S, Young AA, Culter CL, Ivy JL, Abbott WG, Zawadzki JK, Yki-Jarvinen H, Christin L, Secomb TW, and Bogardus C. Skeletal muscle capillary density and fiber type are possible determinants of in vivo insulin resistance in man. J Clin Invest 1987;80:415-24.

9. Brandes R, Fleming I, and Busse R. Endothelial aging. Cardiovasc Res 2005;66:286-94.

10. Broekhuizen LN, Mooij HL, Kastelein JJ, Stroes ES, Vink H, and Nieuwdorp M. Endothelial glycocalyx as potential diagnostic and therapeutic target in cardiovascular disease. Curr Opin Lipidol 2009;20:57-62.

11. Ryan NA, Zwetsloot KA, Westerkamp LM, Hickner RC, Pofahl WE, and Gavin TP. Lower skeletal muscle capillarization and VEGF expression in aged vs. young men. J Appl Physiol 2006;100:178-85.

12. Solomon TP, Haus JM, Li Y, and Kirwan JP. Progressive hyperglycemia across the glucose tolerance continuum in older obese adults is related to skeletal muscle capillarization and nitric oxide bioavailability. J Clin Endocrinol Metab 2011;96:1377-84.

13. Meneilly G, Elliot T, Bryer-Ash M, and Floras J. Insulin-mediated increase in blood flow is impaired in the elderly. J Clin Endocrinol Metab 1995;80:1899-903.

14. Luft J. The structure and properties of the cell surface coat. Int Rev Cytol 1976;45:291-382.

15. Weinbaum S, Tarbell JM, and Damiano ER. The structure and function of the endothelial glycocalyx layer. Annu Rev Biomed Eng 2007;9:121-67.

16. Abele D, Elisa D, Roberta D, Rocco R, Erica A, Paolo P, Can I, and Mervyn S. Alteration of the sublingual microvascular glycocalyx in critically ill patients. Microvasc Res. 2013;90:86-9..

17. Martens R, Vink H, van Oostenbrugge R, and Staals J. Sublingual microvascular glycocalyx dimensions in lacunar stroke patients. Cerebrovascular diseases (Basel, Switzerland) 2013;35:451-4.

18. Snoeijs M, Vink H, Voesten N, Christiaans M, Daemen J-WH, Peppelenbosch A, Tordoir J, Peutz-Kootstra C, Buurman W, Schurink G, and van Heurn L. Acute ischemic injury to the renal microvasculature in human kidney transplantation. Am J Physiol Renal Physiol. 2010;299:F1134-40..

19. van Golen R, van Gulik T, and Heger M. Mechanistic overview of reactive species-induced degradation of the endothelial glycocalyx during hepatic ischemia/reperfusion injury. Free Radic Biol Med 2012;52: 1382-402.

20. Vlahu CA, Lemkes BA, Struijk DG, Koopman MG, Krediet RT, and Vink H. Damage of the endothelial glycocalyx in dialysis patients. J Am Soc Nephrol. 2012;23:1900-8.

21. Baron AD. Insulin resistance and vascular function. J Diabetes Complications 2002;16:92-102.

22. Cade W. Diabetes-related microvascular and macrovascular diseases in the physical therapy setting. Phys Ther 2008;88:1322-35. 
23. Park SW, Goodpaster BH, Lee JS, Kuller LH, Boudreau R, de Rekeneire N, Harris TB, Kritchevsky S, Tylavsky FA, Nevitt M, Cho YW, and Newman AB. Excessive loss of skeletal muscle mass in older adults with type 2 diabetes. Diabetes Care 2009;32:1993-7.

24. Leenders M, Verdijk L, Van der Hoeven L, Adam J, Van Kranenburg J, Nilwik R, and Van Loon LJC. Patients with type 2 diabetes show a greater decline in muscle mass, muscle strength, and functional capacity with aging. J Am Med Dir Assoc. 2013;14:585-92.

25. Ainsworth BE, Haskell WL, Herrmann SD, Meckes N, Bassett DR, Jr., Tudor-Locke C, Greer JL, Vezina J, Whitt-Glover MC, and Leon AS. 2011 Compendium of Physical Activities: a second update of codes and MET values. Med Sci Sports Exerc 2011;43:1575-81.

26. Levy JC, Matthews DR, and Hermans MP. Correct homeostasis model assessment (HOMA) evaluation uses the computer program. Diabetes Care 1998;21:2191-2.

27. Lima A, and Bakker J. Noninvasive monitoring of peripheral perfusion. Intensive Care Med 2005;31: 1316-26.

28. Eskens BJ, Mooij HL, Cleutjens JP, Roos JM, Cobelens JE, Vink H, and Vanteeffelen JW. Rapid insulinmediated increase in microvascular glycocalyx accessibility in skeletal muscle may contribute to insulinmediated glucose disposal in rats. PLoS One 2013;8:e55399.

29. Koopman R, Verdijk LB, Beelen M, Gorselink M, Kruseman AN, Wagenmakers AJ, Kuipers $H$, and van Loon LJ. Co-ingestion of leucine with protein does not further augment post-exercise muscle protein synthesis rates in elderly men. Br J Nutr 2008;99:571-80.

30. Hepple RT, Mackinnon SL, Goodman JM, Thomas SG, and Plyley MJ. Resistance and aerobic training in older men: effects on VO2peak and the capillary supply to skeletal muscle. J Appl Physiol 1997;82: 1305-10.

31. Hepple RT. A new measurement of tissue capillarity: the capillary-to-fibre perimeter exchange index. Can J Appl Physiol 1997;22:11-2.

32. Praet SF, Jonkers RA, Schep G, Stehouwer CD, Kuipers H, Keizer HA, and van Loon LJ. Long-standing, insulin-treated type 2 diabetes patients with complications respond well to short-term resistance and interval exercise training. Eur J Endocrinol 2008;158:163-72.

33. Bastow MD, Rawlings J, and Allison SP. Benefits of supplementary tube feeding after fractured neck of femur: a randomised controlled trial. Br Med J (Clin Res Ed) 1983;287:1589-92.

34. Fujita S, Rasmussen BB, Cadenas JG, Grady JJ, and Volpi E. Effect of insulin on human skeletal muscle protein synthesis is modulated by insulin-induced changes in muscle blood flow and amino acid availability. Am J Physiol Endocrinol Metab 2006;291:E745-54.

35. Guillet C, and Boirie Y. Insulin resistance: a contributing factor to age-related muscle mass loss? Diabetes Metab. 2005;31 Spec No 2:5S20-6.

36. Vincent MA, Clerk LH, Lindner JR, Klibanov AL, Clark MG, Rattigan S, and Barrett EJ. Microvascular recruitment is an early insulin effect that regulates skeletal muscle glucose uptake in vivo. Diabetes 2004;53:1418-23.

37. Nilwik R, Snijders T, Leenders M, Groen B, van Kranenburg J, Verdijk L, and van Loon L. The decline in skeletal muscle mass with aging is mainly attributed to a reduction in type II muscle fiber size. Exp Gerontol 2013;48:492-8.

38. Verdijk L, Koopman R, Schaart G, Meijer K, Savelberg H, and van Loon L. Satellite cell content is specifically reduced in type II skeletal muscle fibers in the elderly. Am J Physiol Endocrinol Metab 2007;292:7.

39. Larsson L, Sjödin B, and Karlsson J. Histochemical and biochemical changes in human skeletal muscle with age in sedentary males, age 22--65 years. Acta physiologica Scandinavica 103: 31-39, 1978.

40. Cuthbertson D, Smith K, Babraj J, Leese G, Waddell T, Atherton P, Wackerhage H, Taylor PM, and Rennie MJ. Anabolic signaling deficits underlie amino acid resistance of wasting, aging muscle. FASEB J 2005;19: 422-4.

41. Bell JA, Fujita S, Volpi E, Cadenas JG, and Rasmussen BB. Short-term insulin and nutritional energy provision do not stimulate muscle protein synthesis if blood amino acid availability decreases. Am J Physiol Endocrinol Metab 2005;289:E999-1006.

42. Fujita S, Glynn EL, Timmerman KL, Rasmussen BB, and Volpi E. Supraphysiological hyperinsulinaemia is necessary to stimulate skeletal muscle protein anabolism in older adults: evidence of a true age-related insulin resistance of muscle protein metabolism. Diabetologia 2009;52 1889-98. 
43. Marin P, Andersson B, Krotkiewski M, and Bjorntorp P. Muscle fiber composition and capillary density in women and men with NIDDM. Diabetes Care 1994;17:382-6.

44. Rodriguez-Manas L, El-Assar M, Vallejo S, Lopez-Doriga P, Solis J, Petidier R, Montes M, Nevado J, Castro M, Gomez-Guerrero C, Peiro C, and Sanchez-Ferrer CF. Endothelial dysfunction in aged humans is related with oxidative stress and vascular inflammation. Aging cell 2009;8:226-38.

45. Boer C, Koning N, Van Teeffelen J, Vonk A, and Vink H. Changes in microcirculatory perfusion during cardiac surgery are paralleled by alterations in glycocalyx integrity. Critical Care 2013;17.

46. Egan B, and Zierath J. Exercise metabolism and the molecular regulation of skeletal muscle adaptation. Cell metabolism 2013;17:162-84.

47. Vollmar B, and Menger M. The hepatic microcirculation: mechanistic contributions and therapeutic targets in liver injury and repair. Physiol Rev 2009;89:1269-339.

48. Schnitzer JE. Transport functions of the glycocalyx, specific proteins, and caveolae in endothelium. In: Whole organ approaches to cellular metabolism, edited by Bassingthwaighte J, Goresky CA, and Linehan JH. New York: Springer, 1998:31-69.

49. Nieuwdorp M, Meuwese MC, Mooij HL, Ince C, Broekhuizen LN, Kastelein JJ, Stroes ES, and Vink H. Measuring endothelial glycocalyx dimensions in humans: a potential novel tool to monitor vascular vulnerability. J Appl Physiol 2008;104:845-52.

50. Broekhuizen LN, Lemkes BA, Mooij HL, Meuwese MC, Verberne H, Holleman F, Schlingemann RO, Nieuwdorp M, Stroes ES, and Vink H. Effect of sulodexide on endothelial glycocalyx and vascular permeability in patients with type 2 diabetes mellitus. Diabetologia. 2010;53:2646-55.

51. Nieuwdorp M, van Haeften TW, Gouverneur MC, Mooij HL, van Lieshout MH, Levi M, Meijers JC, Holleman F, Hoekstra JB, Vink H, Kastelein JJ, and Stroes ES. Loss of endothelial glycocalyx during acute hyperglycemia coincides with endothelial dysfunction and coagulation activation in vivo. Diabetes 2006;55:480-6.

52. Villela N, Kramer-Aguiar L, Bottino D, Wiernsperger N, and Bouskela E. Metabolic disturbances linked to obesity: the role of impaired tissue perfusion. Arq Bras Endocrinol Metabol. 2009;53:238-45.

53. Clark MG. Impaired microvascular perfusion: a consequence of vascular dysfunction and a potential cause of insulin resistance in muscle. Am J Physiol Endocrinol Metab 2008;295:E732-50.

54. De Boer MP, Meijer RI, Wijnstok NJ, Jonk AM, Houben AJ, Stehouwer CD, Smulders YM, Eringa EC, and Serne EH. Microvascular dysfunction: a potential mechanism in the pathogenesis of obesity-associated insulin resistance and hypertension. Microcirculation 2012;19:5-18.

55. Wilkinson SB, Tarnopolsky MA, Macdonald MJ, Macdonald JR, Armstrong D, and Phillips SM. Consumption of fluid skim milk promotes greater muscle protein accretion after resistance exercise than does consumption of an isonitrogenous and isoenergetic soy-protein beverage. Am J Clin Nutr 2007;85:1031-40. 


\section{Chapter}

Intragastric protein administration stimulates overnight muscle protein synthesis in elderly men

Bart B.L. Groen, Peter T. Res, Bart Pennings, Elisabeth Hertle, Joan M.G. Senden, Wim H.M. Saris, Luc J.C. van Loon Am J Physiol Endocrinol Metab. 2012;302:E52-60 


\section{Abstract}

\section{Background}

The loss of skeletal muscle mass with aging has been attributed to an impaired muscle protein synthetic response to food intake. Therefore, nutritional strategies are targeted to modulate postprandial muscle protein accretion in the elderly.

\section{Objective}

To assess the impact of protein administration during sleep on in vivo protein digestion and absorption kinetics and subsequent muscle protein synthesis rates in elderly men.

\section{Design}

16 healthy elderly men were randomly assigned to an experiment during which they were administered a single bolus intrinsically $\mathrm{L}-\left[1{ }^{13} \mathrm{C}\right]$-phenylalanine labeled casein protein (PRO) or a placebo (PLA) during sleep. Continuous infusions with L-[ring- $\left.{ }^{2} \mathrm{H}_{5}\right]$-phenylalanine and $\mathrm{L}-\left[\right.$ ring- $\left.{ }^{2} \mathrm{H}_{2}\right]-$ tyrosine were applied, to assess in vivo dietary protein digestion and absorption kinetics and subsequent muscle protein synthesis rates during sleep.

\section{Results}

Exogenous phenylalanine appearance rates increased following protein administration. The latter stimulated protein synthesis, resulting in a more positive overnight whole body protein balance ( $0.30 \pm 0.1$ vs. $11.8 \pm 1.0 \mu \mathrm{mol}$ phenylalanine $\cdot \mathrm{kg}-1 \cdot \mathrm{h}-1$ in PLA and PRO, respectively; $\mathrm{P}<0.05)$. In agreement, overnight muscle protein fractional synthesis rates were much greater in the PRO experiment $(0.045 \pm 0.002$ vs. $0.029 \pm 0.002 \% \cdot h-1$ respectively; $P<0.05)$ and showed abundant incorporation of the amino acids ingested via the intrinsically labeled protein $\left(0.058 \pm 0.006 \% \cdot h-{ }^{1}\right)$.

\section{Conclusion}

This is the first study to show that dietary protein administration during sleep is followed by normal digestion and absorption kinetics, thereby stimulating overnight muscle protein synthesis. Dietary protein administration during sleep stimulates muscle protein synthesis and improves overnight whole-body protein balance. These findings may provide a basis for novel interventional strategies to attenuate muscle mass loss. 


\section{Introduction}

Aging is accompanied by a progressive decline in skeletal muscle mass and strength, leading to the loss of functional capacity and an increased risk of developing chronic metabolic disease. ${ }^{1,2}$ Disturbances in skeletal muscle protein turnover result in a structural imbalance between protein synthesis and breakdown, leading to sarcopenia. ${ }^{3}$ As basal (fasting) muscle protein synthesis rates do not seem to differ substantially between the young and elderly, ${ }^{4,5}$ many research groups have started to focus on the muscle protein synthetic response to the main anabolic stimuli, i.e. food intake and physical activity. ${ }^{6}$ Recent studies suggest that the skeletal muscle protein synthetic response to food intake is blunted in the elderly. ${ }^{2,7}$ The latter is now believed to represent a key factor responsible for the age-related decline in skeletal muscle mass. ${ }^{2}$ Consequently, we as well as other labs have been trying to define effective interventional strategies to compensate for the greater anabolic resistance by improving postprandial muscle protein accretion in the elderly. The latter has been successfully applied by increasing the amount of dietary protein ingested, ${ }^{8}$ changing the protein source applied, ${ }^{9,10}$ and/or by co-ingesting additional free leucine. ${ }^{11,12}$ However, besides increasing the postprandial muscle protein synthetic response to a single meal, we questioned whether we could compensate for anabolic resistance in the elderly by stimulating overnight muscle protein synthesis.

Recently, we assessed overnight muscle protein synthesis rates in vivo in males. ${ }^{13}$ As overnight muscle protein synthesis rates were shown to be quite low, we questioned whether limited plasma amino acid availability prevents overnight muscle protein synthesis rates to be elevated above basal levels. Consequently, we questioned whether protein provision during sleep would be followed by proper dietary protein digestion and absorption kinetics, resulting in a substantial increase in plasma amino acid availability. Though data on gut function during sleep are scarce, it has been reported that human intestinal motility follows a circadian rhythm with reduced nocturnal activity. ${ }^{14-16}$ Therefore, we first need to determine whether dietary protein provision during sleep allows the digestive tract to function properly. If so, it should be assessed whether an overnight increase in plasma amino acid availability stimulates mixed muscle protein synthesis, and, as such, improves overnight net protein balance. The latter would greatly increase the window of opportunity to modulate muscle protein metabolism and provides an interesting concept upon which novel interventional strategies can be developed to effectively attenuate muscle mass loss in both health and disease.

Following up the work by Beaufrere and Boirie et al. ${ }^{17}$ we recently introduced the application of specifically produced intrinsically $\mathrm{L}-\left[1-{ }^{13} \mathrm{C}\right]$-phenylalanine labeled dietary protein as a means to accurately assess in vivo dietary protein digestion and absorption kinetics and subsequent muscle protein synthesis in humans. ${ }^{18}$ In the present study, we assess in vivo dietary protein digestion and absorption kinetics and the subsequent 
muscle protein synthetic response following dietary protein administration via a nasogastric tube during sleep in elderly men. We hypothesized that dietary protein provision during sleep is accompanied by normal protein digestion and absorption kinetics, thereby stimulating muscle protein synthesis and allowing net muscle protein accretion to occur during overnight sleep. This study establishes proof-of-principle of the efficacy of nighttime protein provision to stimulate muscle protein accretion in the elderly. This novel nutritional intervention concept may proof to be of important clinical relevance to attenuate muscle mass loss.

\section{Materials and methods}

\section{Subjects}

A total of 16 healthy, normoglycemic, elderly men ( $74 \pm 1$ y) were selected to participate in the present study. Subjects' characteristics are presented in Table 5.1. Subjects were randomly assigned to either the placebo (PLA) or protein (PRO) experiment. No differences were observed in subjects' characteristics between experimental groups. All subjects were informed of the nature and possible risks of the experimental procedures before their written informed consent was obtained. This study was approved by the Medical Ethical Committee of the Maastricht University Medical Centre ${ }^{+}$, The Netherlands.

Table 5.1 Subjects' characteristics $(n=16)^{1}$

\begin{tabular}{|c|c|c|}
\hline & Placebo $(n=8)$ & Protein $(n=8)$ \\
\hline Age (y) & $73.9 \pm 1.9$ & $74.0 \pm 2.1$ \\
\hline Body weight (kg) & $78.7 \pm 3.4$ & $79.2 \pm 3.0$ \\
\hline $\mathrm{BMI}\left(\mathrm{kg} \cdot \mathrm{m}^{<}\right)$ & $25.2 \pm 0.8$ & $26.0 \pm 0.7$ \\
\hline Body fat (\%) & $22.4 \pm 1.3$ & $22.1 \pm 1.2$ \\
\hline Lean body mass (kg) & $59.5 \pm 2.3$ & $58.0 \pm 0.5$ \\
\hline Leg volume (L) & $7.62 \pm 0.45$ & $7.42 \pm 0.41$ \\
\hline $\mathrm{HbA1c}$ & $5.8 \pm 0.1$ & $6.0 \pm 0.1$ \\
\hline Basal plasma glucose $\left(\mathrm{mmol} \cdot \mathrm{L}^{-\perp}\right)$ & $5.2 \pm 0.2$ & $5.3 \pm 0.2$ \\
\hline Basal plasma insulin $\left(\mathrm{mU} \cdot \mathrm{L}^{-\perp}\right)$ & $10.7 \pm 0.3$ & $11.3 \pm 0.4$ \\
\hline HOMA-IR & $2.4 \pm 0.1$ & $2.7 \pm 0.2$ \\
\hline
\end{tabular}

1 Values are expressed as means \pm SEM. HbA1c, glycated hemoglobin; HOMA-IR, homeostasis model assessment of insulin resistance. No differences between experimental groups, $P<0.05$.

\section{Pretesting}

All participants performed an oral glucose tolerance test (OGTT) prior to inclusion in the study. Following an overnight fast, participants arrived at the laboratory at $0800 \mathrm{~h}$ by car or public transport. Plasma glucose concentrations were measured to determine oral glucose intolerance and/or the presence of type 2 diabetes according to 2006 
American Diabetes Association guidelines. ${ }^{19}$ Leg volume was measured by anthropometry as described by Jones and Pearson. ${ }^{20}$ Directly after the oral glucose tolerance test, body weight, body composition, and bone mineral content were measured with DXA (Lunar Prodigy Advance; GE Health Care, Madison, WI). The system's software package (en-CORE 2005, version 9.15.00) was used to determine whole-body and regional lean mass, fat mass, and bone mineral content.

\section{Diet and physical activity in testing}

All volunteers were instructed to refrain from any exhaustive physical activity and to keep their diet as constant as possible 3 days prior to the trial. Food intake and physical activity records were collected for 2 days prior to the experiment and were analyzed by a certified dietician. Overall $(n=16)$, habitual daily energy intake was $8.6 \pm 0.4 \mathrm{MJ}$, providing $57 \pm 1$ energy\% (En\%) carbohydrate, $31 \pm 1$ En\% fat, and $12 \pm 0.1$ En\% protein. Total carbohydrate, fat and protein intake averaged $299 \pm 14,73 \pm 3$, and $63 \pm 3 \mathrm{~g}$, respectively. Dietary protein intake averaged $0.80 \pm 0.04 \mathrm{~g} \cdot \mathrm{kg}^{-1}$ bodyweight per day. On the day of the experiment, subjects consumed a standardized breakfast, mid-morning snack, lunch, mid-afternoon snack, and dinner. The standardized diet (3 meals and 2 snacks) provided 9.8 MJ and provided $58 \mathrm{En} \%$ carbohydrate, $30 \mathrm{En} \%$ fat, and $12 \mathrm{En} \%$ protein. Dietary protein intake averaged $0.89 \pm 0.09 \mathrm{~g} \cdot \mathrm{kg}^{-1}$ bodyweight, with $30 \%$ of the protein provided with dinner. In the morning following the nocturnal intervention, hunger rating was assessed using the visual analogue scale. ${ }^{21}$ Subsequently, subjects were invited to have breakfast, for which they were provided with a large range of products that could be consumed ad libitum. Food intake at breakfast was recorded for all subjects.

\section{Study design}

An outline of the study protocol is provided in Figure 5.1. Each subject participated in one experiment, in which $400 \mathrm{~mL}$ water with (PRO) or without (PLA) $40 \mathrm{~g}$ intrinsically $\mathrm{L}-\left[1-{ }^{13} \mathrm{C}\right]$-phenylalanine labeled casein protein was administered via a nasogastric tube during overnight sleep from 0200 to 0205 h. Prior to and after protein administration, plasma and muscle samples were collected. These experiments were designed to simultaneously assess dietary protein digestion and absorption kinetics, splanchnic amino acid extraction, and mixed muscle protein fractional synthetic rate (FSR) in vivo in humans during overnight sleep. 


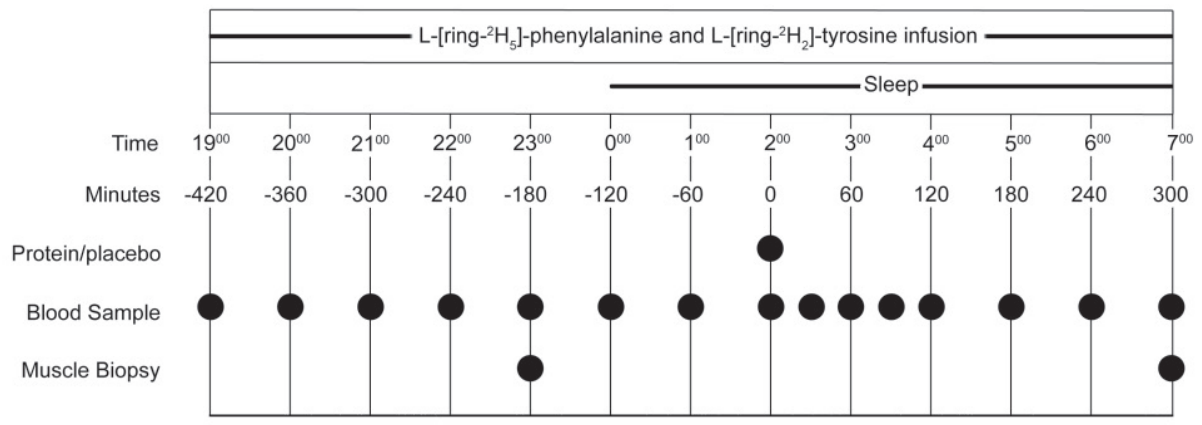

Figure 5.1 Outline of study protocol.

\section{Protocol}

At $1800 \mathrm{~h}$, participants reported to the hospital ward where a nasogastric stomach feeding catheter (Bengmark, Flocare, Zoetermeer, the Netherlands) and 2 Teflon catheters were inserted. The first catheter was inserted into an antecubital vein and the second catheter was inserted into an antecubital vein of the contralateral hand, which was placed in a hotbox to allow arterialized blood sampling. ${ }^{22}$ After collecting a background plasma sample at $1855 \mathrm{~h}$, the plasma phenylalanine pool was primed with a single intravenous dose of labeled phenylalanine and tyrosine (priming dose: $2.4 \mu \mathrm{mol} \cdot \mathrm{kg}^{-1} \mathrm{~L}$-[ring- $\left.{ }^{2} \mathrm{H}_{5}\right]$-phenylalanine, $0.925 \mu \mathrm{mol} \cdot \mathrm{kg}^{-1} \mathrm{~L}$-[ring- $\left.{ }^{2} \mathrm{H}_{2}\right]$-tyrosine). After onset of the continuous stable isotope infusion (infusion rate: $0.06 \mu \mathrm{mol} \cdot \mathrm{kg}^{-1} \cdot \mathrm{min}^{-1}$ $\mathrm{L}$-[ring- ${ }^{2} \mathrm{H}_{5}$ ]-phenylalanine, $0.023 \mu \mathrm{mol} \cdot \mathrm{kg}^{-1} \cdot \mathrm{min}^{-1} \quad \mathrm{~L}$-[ring- ${ }^{2} \mathrm{H}_{2}$ ]-tyrosine, Cambridge Isotopes Laboratories, Andover, MA), a standardized dinner was ingested at $1900 \mathrm{~h}$. Participants rested in a supine position for $3 \mathrm{~h}$. At $2300 \mathrm{~h}$ the first muscle biopsy sample from the M. vastus lateralis was taken. Subsequently, subjects went to sleep at $0000 \mathrm{~h}$. During the night, at $0200 \mathrm{~h}$ a bolus of $400 \mathrm{~mL}$ water with or without $40 \mathrm{~g}$ intrinsically labeled L-[1- $\left.{ }^{13} \mathrm{C}\right]$-phenylalanine labeled casein protein was administered via a nasogastric tube within 5 min without disturbing the subjects in their sleep. A second muscle biopsy was obtained from the $M$. vastus lateralis in the contralateral leg at $0700 \mathrm{~h}$. Blood samples ( $8 \mathrm{~mL}$ ) were taken from the arterialized hand vein at 1900,2000 , 2100, 2200, 2300, 0000, 0100, 0200, 0230, 0300, 0330, 0400, 0500, 0600 and $0700 \mathrm{~h}$.

Blood samples were collected in EDTA containing tubes and centrifuged at $1000 \mathrm{~g}$ for $10 \mathrm{~min}$ at $4^{\circ} \mathrm{C}$. Aliquots of plasma were frozen in liquid nitrogen and stored at $-80^{\circ} \mathrm{C}$. Muscle biopsies were obtained from the middle region of the $M$. vastus lateralis, $15 \mathrm{~cm}$ above the patella and approximately $4 \mathrm{~cm}$ below entry through the fascia, using the percutaneous needle biopsy technique. ${ }^{23}$ Muscle samples were dissected carefully and freed from any visible non-muscle material. The muscle samples were immediately frozen in liquid nitrogen and stored at $-80^{\circ} \mathrm{C}$ until further analysis. 


\section{Protein administration and tracer infusion}

Intrinsically L-[1- $\left.{ }^{13} \mathrm{C}\right]$-phenylalanine labeled casein protein was obtained by infusing a Holstein cow with large quantities of $\mathrm{L}-\left[1-{ }^{13} \mathrm{C}\right]$-phenylalanine, collecting milk, and purifying the casein fraction as described previously. ${ }^{18}$ The $\mathrm{L}-\left[1-{ }^{13} \mathrm{C}\right]$-phenylalanine enrichment in the casein fraction averaged 37.4 MPE. The casein protein met all chemical and bacteriological specifications for human consumption. Subjects were administered either $40 \mathrm{~g}$ intrinsically $\mathrm{L}-\left[1-{ }^{13} \mathrm{C}\right]$-phenylalanine labeled casein protein or a placebo drink (water only) via a nasogastric tube. The stable isotope tracers L-[ring${ }^{2} \mathrm{H}_{5}$ ]-phenylalanine and L-[ring- ${ }^{2} \mathrm{H}_{2}$ ]-tyrosine were purchased from Cambridge Isotopes (Andover, MA) and dissolved in $0.9 \%$ saline before infusion. Continuous intravenous infusions were performed using a calibrated IVAC 598 pump (San Diego, CA, USA). Tracers were prepared by the pharmacy of the Maastricht University Medical Centre ${ }^{+}$.

\section{Plasma analysis}

Plasma glucose (Uni Kit III, 07367204, Roche, Basel, Switzerland) concentrations were analyzed with the COBAS-FARA semi-automatic analyzer (Roche). Insulin was analyzed by radio-immunoassay (Insulin RIA kit, LINCO Research Inc., St. Charles, MO, USA). Plasma $(100 \mu \mathrm{L})$ for amino acid analyses was deproteinized on ice with $4 \mathrm{mg} \mu \mathrm{L}$ of $24 \%$ (w/v) 5-sulphosalicylic acid, mixed and the clear supernatant was collected after centrifugation. Plasma amino acids concentrations were analyzed by an automated, RPHPLC-based amino acid analyser using an automated precolumn derivatization procedure and a ternary solvent system. ${ }^{24}$ For plasma L- $\left[1-{ }^{13} \mathrm{C}\right]$-phenylalanine, L- $\left[1-{ }^{13} \mathrm{C}\right]-$ tyrosine, L-[ring- $\left.{ }^{2} \mathrm{H}_{5}\right]$-phenylalanine, L-[ring- $\left.{ }^{2} \mathrm{H}_{4}\right]$-tyrosine and $\mathrm{L}$-[ring- $\left.{ }^{2} \mathrm{H}_{2}\right]$-tyrosine enrichment measurements, plasma phenylalanine and tyrosine were derivatized to their t-butyldimethylsilyl (TBDMS) derivatives and their ${ }^{13} \mathrm{C}$ and/or ${ }^{2} \mathrm{H}$ enrichments were determined by electron ionization gas chromatography-mass spectrometry (GC-MS, Agilent $6890 \mathrm{~N}$ GC/5973N MSD Little Falls, USA) using selected ion monitoring of masses 336, 337 and 341 for labeled and L-[1- $\left.{ }^{13} \mathrm{C}\right]$ and L-[ring- $\left.{ }^{2} \mathrm{H}_{5}\right]$-phenylalanine, respectively. And masses 466, 467, 468 and 470 were assessed for labeled and unlabeled $\left(1{ }^{13} \mathrm{C}-\right.$, ring ${ }^{2} \mathrm{H}_{2^{-}}$, and ring- ${ }^{2} \mathrm{H}_{4^{-}}$) tyrosine, respectively. ${ }^{25}$ We applied standard regression curves in all isotopic enrichment analyses to assess linearity of the mass spectrometer and to control for the loss of tracer. Enrichments (MPE) were calculated according to Biolo et al. ${ }^{26}$ to correct for the presence of both the L-[1- $\left.{ }^{13} \mathrm{C}\right]$ and L-[ring- $\left.{ }^{2} \mathrm{H}_{5}\right]$-phenylalanine isotopes.

\section{Muscle analyses}

For measurement of L-[1-13 C]-phenylalanine and L-[ring- $\left.{ }^{2} \mathrm{H}_{5}\right]$-phenylalanine enrichment in the free amino acid pool and mixed muscle protein, $55 \mathrm{mg}$ of wet muscle was freezedried. Collagen, blood, and other non-muscle fiber materials were removed from the muscle fibers under a light microscope. The isolated muscle fiber mass (2-3 mg) was 
weighed and 35 volumes ( $7 x$ wet weight of isolated muscle fibers $\times$ wet/dry ratio $5: 1$ ) of ice-cold $2 \%$ perchloric acid (PCA) were added. The tissue was then homogenized and centrifuged. The supernatant was collected and processed in the same manner as the plasma samples, such that intracellular free $\mathrm{L}-\left[1-{ }^{13} \mathrm{C}\right]$-phenylalanine and $\mathrm{L}-\left[\mathrm{ring}_{-}{ }^{2} \mathrm{H}_{5}\right]$ phenylalanine enrichments could be measured using their TBDMS derivatives on a GCMS. The protein pellet was washed with 3 additional $1.5 \mathrm{~mL}$ washes of $2 \%$ PCA, dried and hydrolyzed in $6 \mathrm{M} \mathrm{HCl}$ at $120{ }^{\circ} \mathrm{C}$ for $15-18 \mathrm{~h}$. The hydrolyzed protein fraction was dried under a nitrogen stream while heated to $120{ }^{\circ} \mathrm{C}$, then $50 \%$ acetic acid solution was added, and the hydrolyzed protein was passed over a Dowex exchange resin (AG 50W-X8, 100-200 mesh hydrogen form, Biorad, Hercules, CA, USA) using $2 \mathrm{M} \mathrm{NH} 4 \mathrm{OH}$. The eluate was divided over 2 vials for separate measurement of both $\mathrm{L}-\left[1{ }^{13} \mathrm{C}\right]-$ phenylalanine and L-[ring- $\left.{ }^{2} \mathrm{H}_{5}\right]$-phenylalanine enrichment in mixed muscle protein as described previously. In short, L-[1- $\left.{ }^{13} \mathrm{C}\right]$-phenylalanine and L-[ring- $\left.{ }^{2} \mathrm{H}_{5}\right]$-phenylalanine were derivatized to their $\mathrm{N}(\mathrm{O}, \mathrm{S})$-ethoxycarbonyl ethyl esters and MTBSTFAphenylethylamines, respectively. ${ }^{27}$ Thereafter, the ratios labeled/unlabeled derivatives were determined by GC-IRMS (Finnigan MAT 252, Bremen, Germany) and GC-MS, respectively. Standard regression curves were applied to assess linearity of the mass spectrometer and to control for loss of tracer.

\section{Calculations}

Ingestion of L-[1- $\left.{ }^{13} \mathrm{C}\right]$-phenylalanine labelled protein, intravenous infusion of L-[ring${ }^{2} \mathrm{H}_{5}$ ]-phenylalanine, and arterialized blood sampling were used to assess whole-body amino acid kinetics in non-steady state conditions. Total, exogenous, and endogenous rate of appearance $\left(R_{a}\right)$ and splanchnic extraction (i.e., fraction of dietary amino acid taken up by all other organs except from muscle tissue and plasma volume, Sp) for phenylalanine was calculated using modified Steele's equations. ${ }^{28,29}$ These parameters were calculated as follows:

Total $\mathrm{R}_{\mathrm{a}}=\frac{F-p V \cdot C(t) \cdot \frac{\Delta E_{i v}}{\Delta t}}{E_{i v}(t)}$

$\operatorname{ExoR}_{a}=\frac{\operatorname{Total}_{a} \cdot E_{p o}(t)+\left[p V \cdot C(t) \cdot \frac{\Delta E_{p o}}{\Delta t}\right]}{E_{\text {prot }}}$

$\operatorname{EndoR}_{a}=$ TotalR $_{a}-$ ExoR $_{a}-F$ 


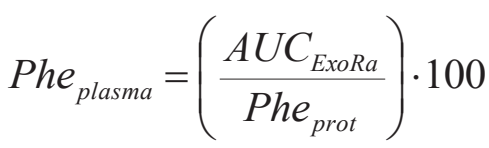

where $F$ is the intravenous tracer infusion rate $\left(\mu \mathrm{mol} \cdot \mathrm{kg}^{-1} \cdot \mathrm{min}^{-1}\right), p V(0.125)$ is the distribution volume for phenylalanine (10). $C(t)$ is the mean plasma phenylalanine concentration between 2 time points. $\Delta E_{i v} / \Delta t$ represents the time-dependent variations of plasma phenylalanine enrichment derived from the intravenous tracer and $E_{i v}(t)$ is the mean plasma phenylalanine enrichment from the intravenous tracer between 2 consecutive time points. Exo $R_{a}$ represents the plasma entry rate of dietary phenylalanine, $E_{p o}(t)$ is the mean plasma phenylalanine enrichment for the oral tracer, $\Delta E_{p o} / \Delta t$ represents the time-dependent variations of plasma phenylalanine enrichment derived from the oral tracer and $E_{\text {prot }}$ is the $\mathrm{L}-\left[1-{ }^{13} \mathrm{C}\right]$-phenylalanine enrichment in the dietary protein. Phe $e_{\text {Prot }}$ is the amount of dietary phenylalanine ingested, $A \cup C_{E x o R a}$ represents the area under the curve $(A \cup C)$ of Exo phe $R_{a}$, which corresponds to the amount of dietary phenylalanine that appeared in the blood over a $5 \mathrm{~h}$ period following ingestion by nasogastric tube.

Total rate of disappearance of phenylalanine equals the rate of phenylalanine hydroxylation (first step in phenylalanine oxidation) and utilization for protein synthesis. This parameter is calculated as follows:

$$
R_{d}=\operatorname{TotalR}_{a}-p V \cdot \frac{\Delta C}{\Delta t}
$$

As whole-body $R_{d}$ comprise the rate of phenylalanine disappearance from the free amino acid pool in the blood due to protein synthesis (S) and oxidation, whole-body protein synthesis can be calculated as $R_{d}$ minus oxidation. Whole-body phenylalanine oxidation can be determined from the conversion (hydroxylation) of L-[ring- $\left.{ }^{2} \mathrm{H}_{5}\right]$ phenylalanine to $\mathrm{L}-\left[\mathrm{ring}^{2} \mathrm{H}_{4}\right]$-tyrosine. The rate of hydroxylation was calculated by using the following formula ${ }^{30}$ :

$$
P h e_{\text {hydroxylation }}=\operatorname{TyrR}_{a} \cdot \frac{E_{\text {Tyr }}(t)}{E_{\text {Phe }}(t)} \cdot \frac{P h e R_{d}}{F_{i v}+P h e R_{d}}
$$

where $E_{t}(\mathrm{t})$ and $\mathrm{E}_{p}(\mathrm{t})$ are the L-[ring- $\left.{ }^{2} \mathrm{H}_{4}\right]$-tyrosine and L-[ring- $\left.{ }^{2} \mathrm{H}_{5}\right]$-phenylalanine enrichments in plasma between 2 consecutive time points, respectively, and $F$ is the infusion rate of phenylalanine. Whole-body protein synthesis was calculated using: 
$S=R_{d}-$ Phe $_{\text {hydroxylation }}$

Fractional rate of mixed muscle protein synthesis $(F S R)$ was calculated by dividing the increment in enrichment in the product, i.e. protein-bound $\mathrm{L}-\left[1-{ }^{13} \mathrm{C}\right]$-phenylalanine or $\mathrm{L}-\left[\right.$ ring- $\left.{ }^{2} \mathrm{H}_{5}\right]$-phenylalanine, by the enrichment of the precursor. Non-steady state plasma L-[1- $\left.{ }^{13} \mathrm{C}\right]$-phenylalanine and plasma $\mathrm{L}-\left[\right.$ ring- $\left.{ }^{2} \mathrm{H}_{5}\right]$-phenylalanine enrichments were used as the preferred precursor pools to estimate mixed muscle protein fractional synthesis rates from both the ingested (dietary protein bound L- $\left[1-{ }^{13} \mathrm{C}\right]$-phenylalanine) or continuously infused ( $\mathrm{L}$-[ring- $\left.{ }^{2} \mathrm{H}_{5}\right]$-phenylalanine) tracer. Consequently, muscle $F S R^{\prime} S$ were calculated as follows ${ }^{31}$ :

$$
F S R=\frac{E_{B}(t)-E_{B}(0)}{\int_{t_{0}}^{t_{1}} E_{F}(t) \cdot \Delta t} \cdot 100
$$

where $E_{F}$ and $E_{B}$ are the enrichments of free and bound amino acid, respectively $\mathrm{L}-\left[1-{ }^{13} \mathrm{C}\right]$-phenylalanine or L-[ring- $\left.{ }^{2} \mathrm{H}_{5}\right]$-phenylalanine, during incorporation periods. $\mathrm{E}_{\mathrm{F}}$ is the average plasma L- $\left[1-{ }^{13} \mathrm{C}\right]$-phenylalanine or plasma $\mathrm{L}$-[ring- $\left.{ }^{2} \mathrm{H}_{5}\right]$-phenylalanine enrichment during the time period for determination of amino acid incorporation. $t$ Indicates the time interval $(\mathrm{h})$ between biopsies.

\section{Statistics}

All data are displayed as arithmetic means \pm standard error of means (SEM; $=\mathrm{SD} /$ Vnumber of subjects). Time-dependent variables as plasma amino acid concentrations, plasma enrichments and whole body protein kinetics were analyzed by two-factor repeated measures ANOVA and by calculating the AUC in both groups. Group dependent variables as AUC and FSR were analyzed by student's t-test. Twofactor repeated measures ANOVA was conducted with group as between-subjects factor and time as within-subjects factor. In order to differentiate the protein effect and to control group homogeneity prior to the intervention, two-factor repeated measures ANOVA was carried out separately for the period from $t=-6 h$ to $t=0 h$. and for the period after the protein administration between $\mathrm{t}=0 \mathrm{~h}$ and $\mathrm{t}=5 \mathrm{~h}$. Statistical significance was set at $P<0.05$. All calculations were performed using SPSS 15.0 (SPSS Inc., Chicago, Illinois, USA). 


\section{Results}

\section{Plasma analysis}

Plasma glucose and insulin concentrations increased rapidly after dinner and normalized to baseline levels prior to the first biopsy that was obtained at $2300 \mathrm{~h}$. Plasma glucose concentrations averaged $5.2 \pm 0.0$ and $5.5 \pm 0.1 \mathrm{mmol} \cdot \mathrm{L}^{-1}$ between 2300 and $0700 \mathrm{~h}$ in the PLA and PRO experiment, respectively. Casein administration at $0200 \mathrm{~h}$ did not modulate circulating plasma glucose concentrations. Plasma insulin concentrations between 2300 and $0700 \mathrm{~h}$ averaged $10.7 \pm 0.3$ and $19.1 \pm 2.1 \mathrm{mU} \cdot \mathrm{L}^{-1}$ in the PLA and PRO experiment, respectively $(P<0.05)$. Provision of intrinsically labeled casein resulted in a small but significant increase in circulating plasma insulin concentrations. Plasma insulin levels peaked $60 \mathrm{~min}$ after protein administration at $33.8 \pm 4.9 \mathrm{mU} \cdot \mathrm{L}^{-1}$ in the PRO experiment, compared with $11.6 \pm 2.1 \mathrm{mU}^{-1}$ in the PLA experiment $(P<0.05)$. Thereafter, plasma insulin levels returned to values that were no longer different between experiments (data not shown).

Plasma phenylalanine, leucine, and essential amino acids concentrations over time are illustrated in Figure 5.2. No differences in basal plasma amino acid concentrations were observed between experimental groups. After administration of intrinsically labeled casein, plasma amino acid concentrations increased rapidly and remained significantly elevated for the remaining $5 \mathrm{~h}$. Plasma amino acid concentrations were significantly higher in the PRO compared with the PLA experiment. Peak plasma phenylalanine $\left(154 \pm 14 \mu \mathrm{mol} \cdot \mathrm{L}^{-1}\right)$ and leucine $\left(449 \pm 31 \mu \mathrm{mol} \cdot \mathrm{L}^{-1}\right)$ concentrations were reached within $30 \mathrm{~min}$ after protein administration.

Continuous infusions with L-[ring- $\left.{ }^{2} \mathrm{H}_{5}\right]$-phenylalanine and L-[ring- $\left.{ }^{2} \mathrm{H}_{2}\right]$-tyrosine were applied in both experiments from $1900 \mathrm{~h}$ till $0700 \mathrm{~h} . \mathrm{L}-\left[1-{ }^{13} \mathrm{C}\right]$-phenylalanine labeled casein was administered via a nasogastric tube at $0200 \mathrm{~h}$ in the PRO experiment. Plasma tracer enrichments from infused and ingested amino acid tracers are illustrated in Figure 5.3A-D. At baseline, plasma tracer enrichments were similar in the PLA and PRO experiment. Directly after $\mathrm{L}-\left[1-{ }^{13} \mathrm{C}\right]$-phenylalanine labeled casein administration, plasma $\mathrm{L}-\left[1-{ }^{13} \mathrm{C}\right]$-phenylalanine and $\mathrm{L}-\left[1-{ }^{13} \mathrm{C}\right]$-tyrosine enrichments increased rapidly, reaching peak levels of $17.3 \pm 1.2$ and $6.2 \pm 0.3 \mathrm{MPE}$ after 30 and $60 \mathrm{~min}$, respectively (Figure 5.3A-B). Plasma L-[1- $\left.{ }^{13} \mathrm{C}\right]$-phenylalanine enrichments subsequently declined to 8.30 $\pm 0.27 \mathrm{MPE} 5 \mathrm{~h}$ after administration of the protein drink. No $\left[1-{ }^{13} \mathrm{C}\right]$-phenylalanine labeled protein was provided in the PLA experiment and, as such, enrichments levels were nil. Plasma L-[ring- $\left.{ }^{2} \mathrm{H}_{5}\right]$-phenylalanine and $\mathrm{L}$-[ring- $\left.{ }^{2} \mathrm{H}_{2}\right]$-tyrosine enrichments declined following protein administration in the PRO experiment, and remained well below the levels observed in the PLA experiment throughout the remainder of the night (Figure 5.3C-D). 

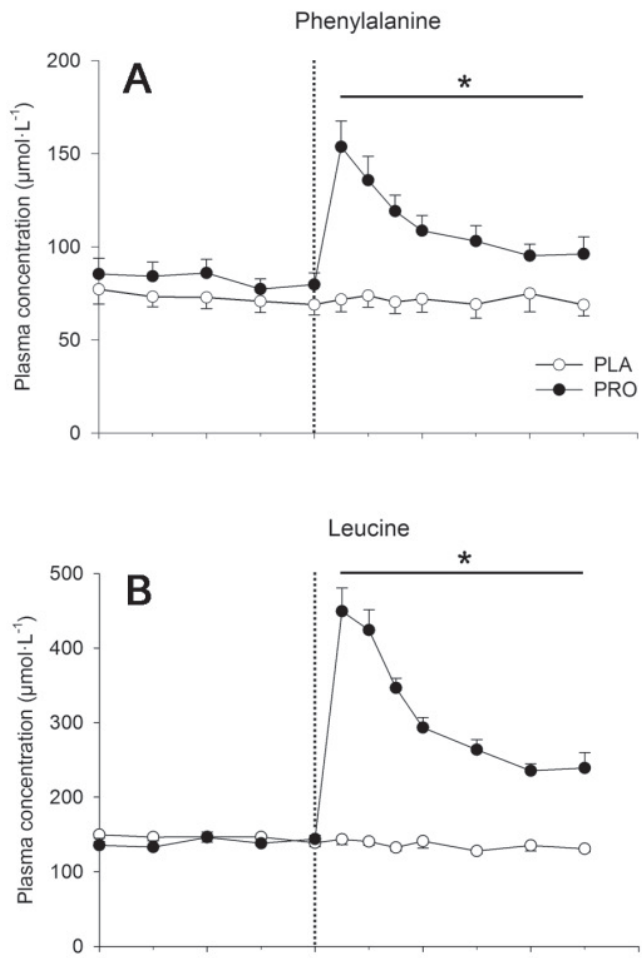

Essential amino acids

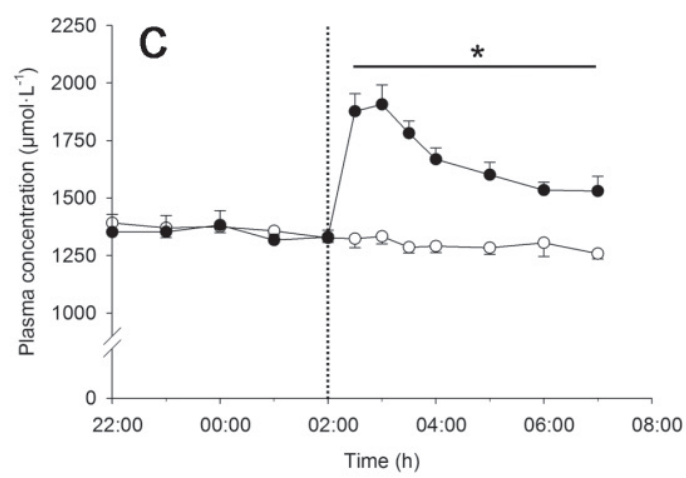

Figure 5.2 Plasma phenylalanine, leucine and total essential amino acid concentrations. Values are expressed as means \pm SEM. PLA, placebo experiment; PRO, protein experiment. Data were analyzed with ANOVA repeated measures (treatment $x$ time). Plasma phenylalanine: treatment effect, $P<0.01$; time effect, $P<0.01$; interaction of treatment and time, $P<0.01$. Plasma tyrosine: treatment effect, $P<0.01$; time effect, $P<0.01$; interaction of treatment and time, $P<0.01$. Plasma leucine: treatment effect, $P<0.01$; time effect, $P<0.01$; interaction of treatment and time, $P<0.01$. Plasma total essential amino acids: treatment effect, $P<0.01$; time effect, $P<0.01$; interaction of treatment and time, $P<0.01 .{ }^{*}$ significantly different from PLA (Scheffe's post hoc test, $P<0.05)$. 


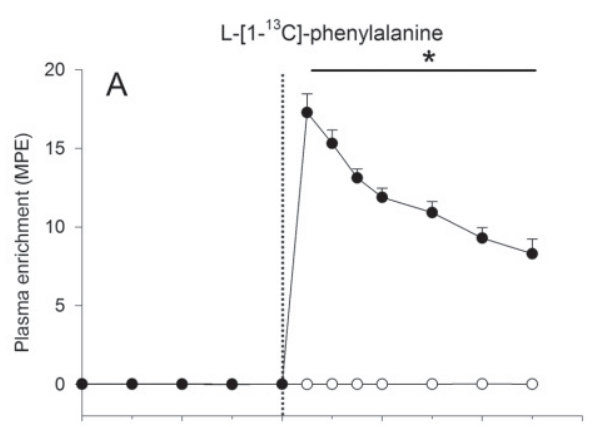

L-[ring- ${ }^{2} \mathrm{H}_{5}$ ]-phenylalanine

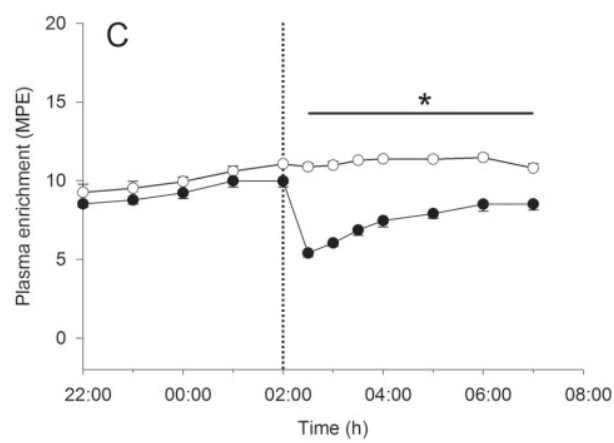

L-[1- $\left.{ }^{13} \mathrm{C}\right]-$ tyrosine

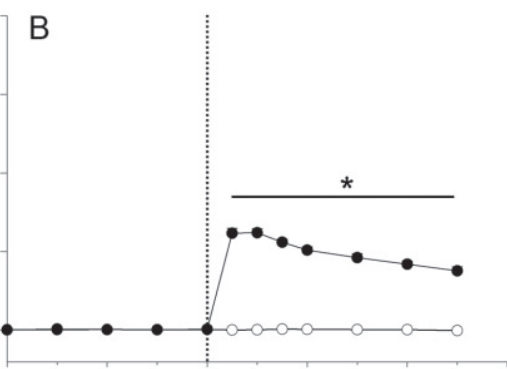

L-[ring- ${ }^{2} \mathrm{H}_{2}$ ]-tyrosine

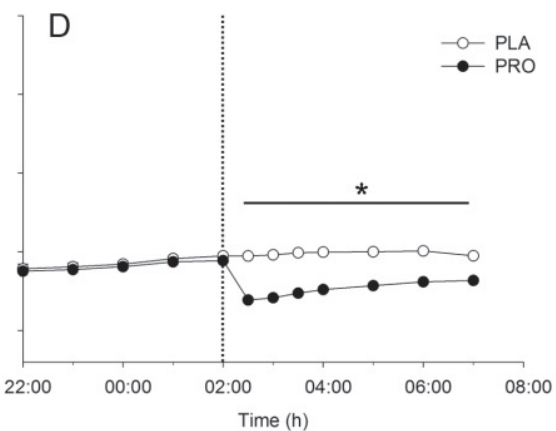

Figure 5.3 Plasma L- $\left[1-{ }^{13} \mathrm{C}\right]$-phenylalanine $(\mathrm{A}), \mathrm{L}-\left[1-{ }^{13} \mathrm{C}\right]$-tyrosine $(\mathrm{B}), \mathrm{L}-\left[\right.$ ring- $\left.{ }^{2} \mathrm{H}_{5}\right]-$ phenylalanine $(\mathrm{C})$ and $\mathrm{L}-$ [ring- ${ }^{2} \mathrm{H}_{2}$ ]-tyrosine (D) enrichments. MPE, mole percent excess. PLA, placebo experiment; PRO, protein experiment. Values are expressed as means \pm SEM. Data were analyzed with ANOVA repeated measures (treatment $x$ time). Plasma L- $\left[1-{ }^{13} \mathrm{C}\right]$-phenylalanine: treatment effect, $P<0.01$; time effect, $P<0.01$; interaction of treatment and time, $P<0.01 . \mathrm{L}-\left[1-{ }^{13} \mathrm{C}\right]$-tyrosine enrichment: treatment effect, $P<0.01$; time effect, $P<0.01$; interaction of treatment and time, $P<0.01$. L- $\left[\right.$ ring $\left.-{ }^{2} \mathrm{H}_{5}\right]$-phenylalanine enrichment: treatment effect, $P<0.01$; time effect, $P<0.01$; interaction of treatment and time, $P<0.01$. L-[ring- ${ }^{2} \mathrm{H}_{2}$ ]-tyrosine enrichment: treatment effect, $P<0.01$; time effect, $P<0.01$; interaction of treatment and time, $P<0.01$. * significantly different from PLA (Scheffe's post hoc test, $P<0.05)$.

\section{Plasma amino acids kinetics}

Whole-body plasma amino acid kinetics are presented in Figure 5.4A-E. Immediately after administration of the intrinsically labeled casein, exogenous $\left[1-{ }^{13} \mathrm{C}\right]$-phenylalanine entered the circulation. Exogenous phenylalanine appearance rates reached peak values at $\left(0.43 \pm 0.03 \mu \mathrm{mol} \cdot \mathrm{kg}^{-1} \cdot \mathrm{min}^{-1}\right)$ within $60 \mathrm{~min}$ after protein administration (Figure 5.4A). In response, endogenous plasma phenylalanine appearance rates declined in the PRO experiment and remained well below levels observed in the PLA experiment. Whole-body plasma phenylalanine disappearance rate followed the rate of appearance, and showed significant postprandial phenylalanine disposal in the PRO experiment 
(Figure 5.4C). In the PRO experiment, postprandial L- $\left[1-{ }^{13} \mathrm{C}\right]-$ phenylalanine extraction in the splanchnic area between 0200 and $0700 \mathrm{~h}$ averaged $42 \pm 4 \%$. Conversion of L-[ring${ }^{2} \mathrm{H}_{5}$ ]-phenylalanine to $\mathrm{L}$-[ ring- ${ }^{2} \mathrm{H}_{4}$ ]-tyrosine was higher in the PRO compared with the PLA experiment (Figure 5.4D).
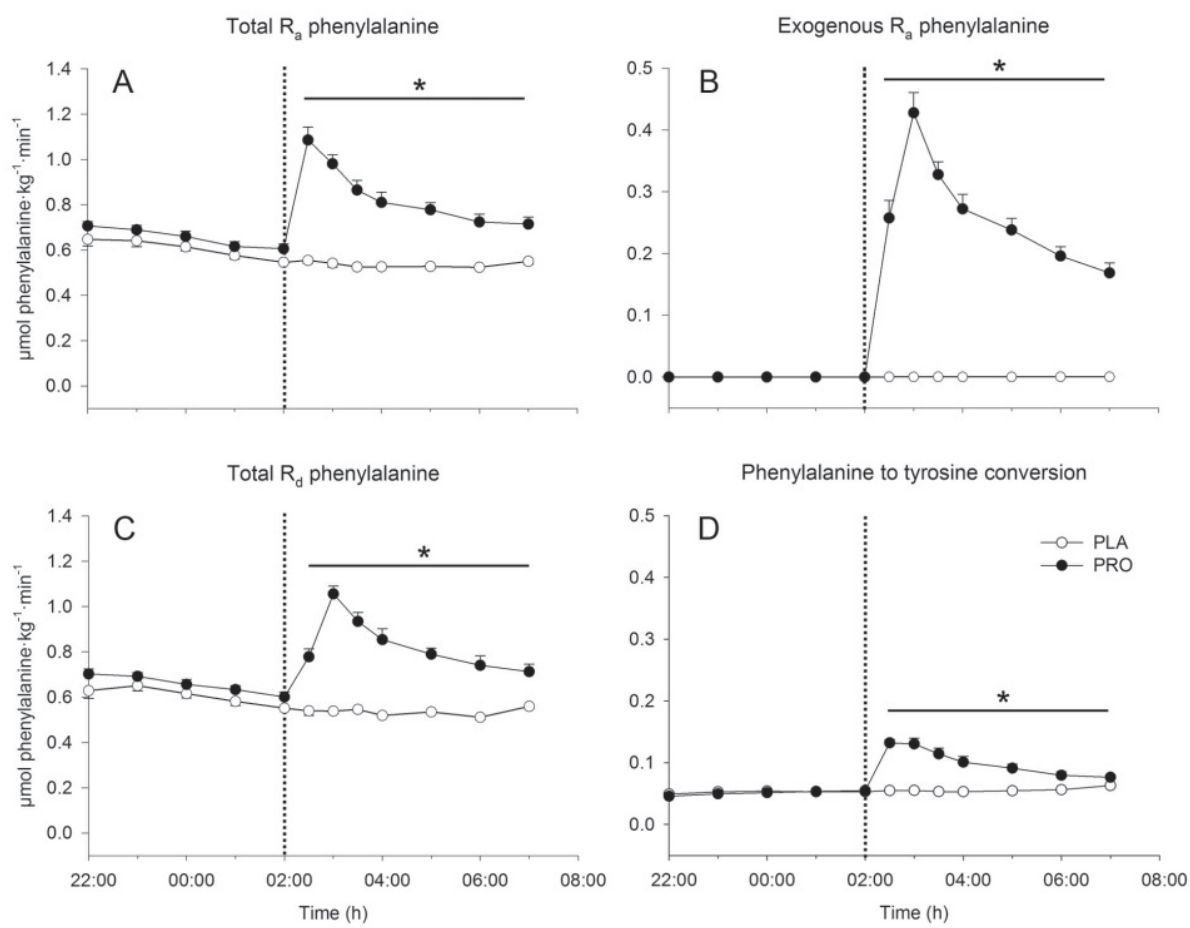

Figure 5.4 Exogenous phenylalanine $\mathrm{Ra}(\mathrm{A})$, total phenylalanine rate of appearance $(\mathrm{B})$, total phenylalanine rate of disappearance (C) and phenylalanine to tyrosine conversion (D). PLA, placebo experiment; PRO, protein experiment. Values represent means \pm SEM. Data were analyzed with ANOVA repeated measures (treatment $x$ time). Exogenous plasma phenylalanine Ra: treatment effect, $P<0.01$; time effect, $P<0.01$; interaction of treatment and time, $P<0.01$. Total plasma phenylalanine Ra: treatment effect, $P<0.01$; time effect, $P<0.01$; interaction of treatment and time, $P<0.01$. Total plasma phenylalanine Rd: treatment effect, $P<0.01$; time effect, $P<0.01$; interaction of treatment and time, $P<0.01$. Plasma phenylalanine to tyrosine conversion: treatment effect, $P<0.01$; time effect, $P<0.01$; interaction of treatment and time, $P<0.01$.

* significantly different from PLA (Scheffe's post hoc test, $P<0.05$ ).

Calculated whole-body protein synthesis and oxidation rates were significantly higher in the PRO versus the PLA experiment. In agreement, net protein balance following protein administration was significantly higher in the PRO compared with the PLA experiment $\left(11.8 \pm 1.0\right.$ and $0.3 \pm 0.1 \mu \mathrm{mol}$ phenylalanine $\cdot \mathrm{kg}^{-1} \cdot \mathrm{h}^{-1}$, respectively; $P<0.05$; Figure 5.5). 
Net protein balance

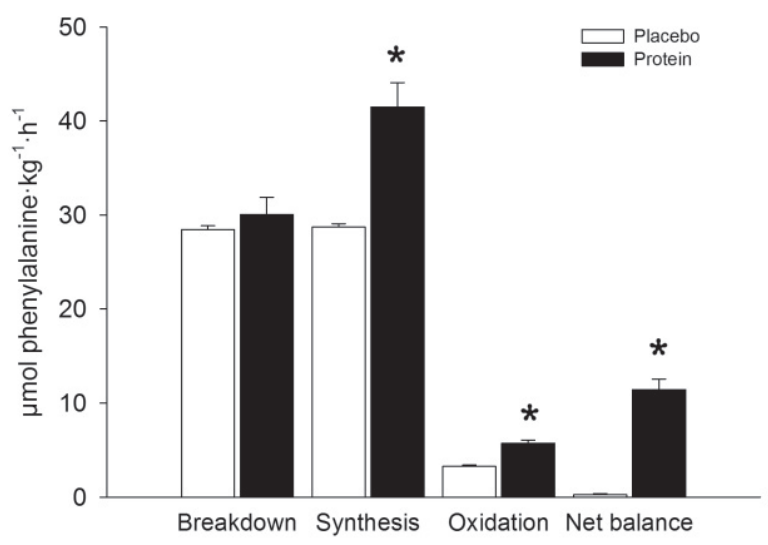

Figure 5.5 Net protein balance. Rates of whole body protein breakdown, synthesis, and oxidation rates, and net protein balance (expressed as $\mu \mathrm{mol}$ phenylalanine $\cdot \mathrm{kg}^{-1} \cdot \mathrm{h}^{-1}$ ) in the PLA and PRO experiment assessed over $5 \mathrm{~h}$ following protein administration (0200 till $0700 \mathrm{AM}$ ). PLA, placebo experiment; PRO, protein experiment. Values represent means \pm SEM. Data were analyzed with an unpaired Student's t-test * significantly different from PLA $(P<0.05)$.

\section{Muscle tissue analysis}

Muscle tissue analyses were performed on muscle biopsy samples collected before, and $5 \mathrm{~h}$ after protein or placebo administration. Muscle free and muscle protein bound $\mathrm{L}$-[ring- ${ }^{2} \mathrm{H}_{5}$ ]-phenylalanine enrichments increased equally in the PLA and PRO experiment. Continuous infusion of L-[ring- $\left.{ }^{2} \mathrm{H}_{5}\right]$-phenylalanine resulted in a muscle free $\mathrm{L}$-[ring- ${ }^{2} \mathrm{H}_{5}$ ]-phenylalanine enrichments of 7.16 \pm 0.32 and $6.32 \pm 0.35 \mathrm{MPE}$ in the PLA and PRO experiment, respectively $(P<0.05)$. The increase in muscle protein bound $\mathrm{L}$-[ring- ${ }^{2} \mathrm{H}_{5}$ ]-phenylalanine enrichments averaged $0.000254 \pm 0.0000145$ and $0.000300 \pm 0.0000161 \mathrm{MPE}$ in the PLA and PRO experiment, respectively $(P=0.04)$. Following the gastric administration of intrinsically $L-\left[1-{ }^{13} \mathrm{C}\right]$-phenylalanine labeled protein, muscle free $\mathrm{L}-\left[1-{ }^{13} \mathrm{C}\right]$-phenylalanine enrichment had increased up to $6.20 \pm 0.65$ MPE in the PRO experiment. Muscle protein bound L- $\left[1-{ }^{13} \mathrm{C}\right]$-phenylalanine enrichment had increased to $0.000322 \pm 0.0000286 \mathrm{MPE}$ during overnight sleep.

\section{Mixed muscle fractional synthesis rates}

Mixed muscle protein synthesis rates, expressed as fractional synthetic rates (FSR), are presented in Figure 5.6A-B. Muscle biopsies were taken at $2300 \mathrm{~h}$ and $0700 \mathrm{~h}$. Mixed muscle protein FSR, with the mean plasma $\mathrm{L}$-[ring- $\left.{ }^{2} \mathrm{H}_{5}\right]$-phenylalanine enrichment as precursor, was significantly higher in the PRO compared with the PLA experiment 
$\left(0.045 \pm 0.002\right.$ and $0.029 \pm 0.002 \% \cdot h^{-1}$, respectively; $\left.P<0.05\right)$. In agreement, a substantial net increase in muscle protein bound $\mathrm{L}-\left[1-{ }^{13} \mathrm{C}\right]$-phenylalanine was observed in the PRO experiment. With the mean plasma $\mathrm{L}-\left[1-{ }^{13} \mathrm{C}\right]$-phenylalanine enrichment as precursor, mixed muscle protein FSR from the ingested protein averaged $0.058 \pm 0.006 \% \cdot \mathrm{h}^{-1}$ (Figure 5.6B).
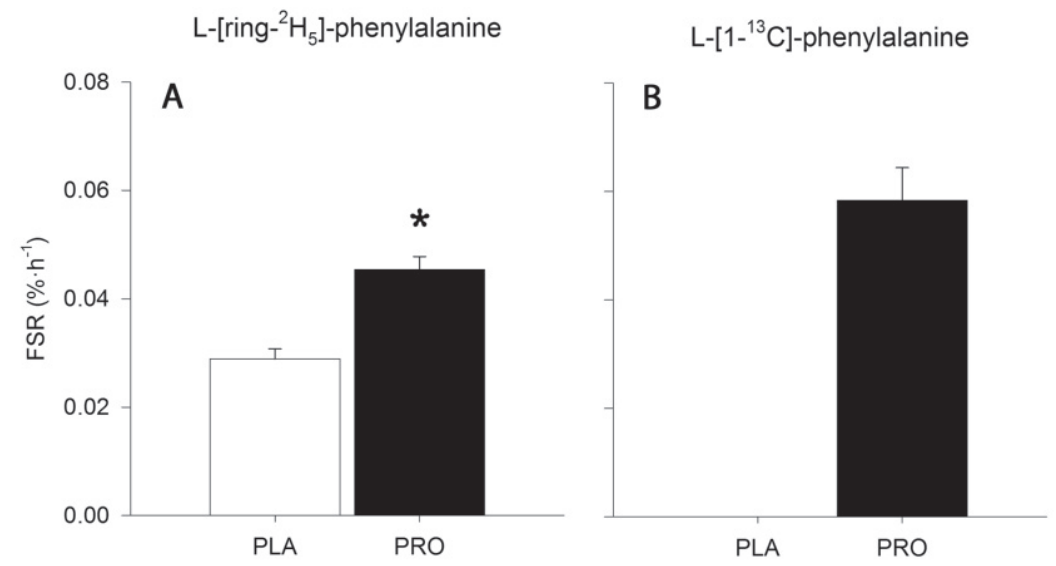

Figure 5.6 Overnight mixed muscle protein fractional synthetic rate (FSR) following placebo or protein administration in the PLA and PRO experiment using intravenous [ring- ${ }^{2} \mathrm{H}_{5}$ ]-phenylalanine infusion (A) and ingestion of intrinsically $L-\left[1-{ }^{13} \mathrm{C}\right]$-phenylalanine labeled protein (B). PLA, placebo experiment; PRO, protein experiment. Data were analyzed with an unpaired student's t-test * significantly different from PLA $(P<0.05)$.

\section{Satiety after intervention}

In the PRO experiment, subjects were provided with $40 \mathrm{~g}$ casein at night, representing $62.0 \pm 2.0 \%$ of their habitual daily protein intake. The following morning, hunger ratings were assessed by using the Visual Analogue Scale (VAS) with scores of $47 \pm 9$ vs. $24 \pm 4 \%$ $(P<0.05)$ in the PLA and PRO experiment, respectively. ${ }^{21}$ Energy intake $(2.5 \pm 0.5$ and 2.1 $\pm 0.4 \mathrm{MJ} ; P=0.48)$ and total protein intake $(20.9 \pm 4.9$ and $18.2 \pm 3.3 ; P=0.65)$ with breakfast did not differ between the PLA and PRO experiment, respectively.

\section{Discussion}

In the present study, we show that dietary protein administration by nasogastric tube feeding during overnight sleep is accompanied by normal dietary protein digestion and absorption kinetics in healthy, elderly men. Protein provision during sleep increases plasma amino acid availability and stimulates skeletal muscle protein synthesis, improving overnight whole-body protein balance. 
The loss of muscle mass with aging has been associated with a blunted skeletal muscle protein synthetic response to food intake. ${ }^{7,32}$ Consequently, many research groups have been trying to define effective dietary strategies to augment the postprandial muscle protein synthetic response to meal ingestion in the elderly..$^{8,11,33,34}$ In contrast, we speculated on the potential to stimulate overnight muscle protein synthesis by providing dietary protein during sleep. The provision of protein during overnight sleep might enlarge the window of opportunity to improve $24 \mathrm{~h}$ protein balance. However, it is generally assumed that food digestion and absorption is not efficient during overnight sleep. It has been reported that human intestinal motility follows a circadian rhythm with reduced nocturnal activity. ${ }^{14-16}$ Therefore, the first question that needs to be addressed is whether dietary protein administration during sleep is followed by normal protein digestion and absorption kinetics. Subsequently, it needs to be established whether this will effectively increase plasma amino acid availability, which is required to stimulate muscle protein synthesis. ${ }^{35,36}$ To address these questions, we administered $40 \mathrm{~g}$ intrinsically L-[1- $\left.{ }^{13} \mathrm{C}\right]$-phenylalanine labeled protein via a nasogastric tube in elderly subjects during their sleep (Figure 5.1). We specifically produced intrinsically $\mathrm{L}-\left[1-{ }^{13} \mathrm{C}\right]$-phenylalanine labeled milk protein by infusing large amounts of $\mathrm{L}-\left[1-{ }^{13} \mathrm{C}\right]$-phenylalanine in lactating Holstein cows. ${ }^{18}$ The use of dietary protein with labeled amino acids incorporated within the protein allows accurate in vivo assessment of dietary protein digestion and absorption kinetics and the subsequent metabolic fate of the ingested amino acids in humans.

Directly after intragastric protein administration, plasma amino acid concentrations rapidly increased and remained elevated throughout the remainder of the night (Figure 5.2). Peak essential amino acid concentrations were observed within 30 min after protein administration (Figure 5.2C). The latter was entirely attributed to the digestion and absorption of the administered protein, as plasma L-[1- $\left.{ }^{13} \mathrm{C}\right]$-phenylalanine enrichments increased immediately after protein administration, reaching peak values within $60 \mathrm{~min}$ (Figure 5.3). In accordance, calculated exogenous phenylalanine appearance rates rapidly increased following protein administration, showing that dietary protein provision during sleep is followed by normal dietary protein digestion and absorption (Figure 5.4). The latter does not seem to be different from digestion and absorption kinetics when protein is ingested during daytime. The amount of dietary protein derived phenylalanine that became available in the circulation during the $5 \mathrm{~h}$ postprandial period averaged $58 \pm 4 \%$. The latter is in line with previous work reporting similar findings after ingesting 20-35 g casein or whey protein in the morning following an overnight fast. ${ }^{4,29,37}$ In fact, when comparing the increase in exogenous amino acid appearance rates following casein ingestion reported in Koopman et al. ${ }^{10}$ with the present findings, it might even be speculated that casein digestion and absorption was even more rapid when provided during overnight sleep. The present results demonstrate that the gastrointestinal tract is fully functional during overnight sleep 
when food is made available, allowing proper dietary protein digestion and absorption in healthy, elderly men.

We combined the use of specifically produced, high level intrinsically $L-\left[1-{ }^{13} \mathrm{C}\right]-$ phenylalanine labeled dietary protein with continuous intravenous L-[ring- $\left.{ }^{2} \mathrm{H}_{5}\right]-$ phenylalanine infusion to allow accurate assessment of exogenous protein digestion and absorption kinetics, but also to study its subsequent impact on whole-body and muscle protein metabolism. Whole-body muscle protein synthesis rates increased rapidly following protein administration, resulting in much higher whole-body protein synthesis rates in the PLA vs. PRO experiment (Figure 5.5). In agreement, overnight whole-body protein balance was more positive in the PRO compared with the PLA experiment. The latter shows that dietary protein provided during sleep is absorbed and retained, thereby allowing whole-body protein accretion. However, it should be noted that changes in whole-body protein kinetics do not necessarily represent changes on a muscle tissue level. ${ }^{38}$

Therefore, we also determined mixed muscle protein fractional synthesis rates by measuring both the incorporation of $\mathrm{L}-\left[\mathrm{ring}^{-2} \mathrm{H}_{5}\right]$-phenylalanine as well as $\mathrm{L}-\left[1-{ }^{13} \mathrm{C}\right]-$ phenylalanine in skeletal muscle protein from biopsies collected prior to sleep and after waking up at $0700 \mathrm{~h}$ in the morning. Muscle protein fractional synthesis rates derived from the incorporation of L-[ring- $\left.{ }^{2} \mathrm{H}_{5}\right]$-phenylalanine showed much higher synthesis rates when protein was provided during sleep. These results show that protein administration during sleep strongly stimulates mixed muscle protein synthesis (Figure 5.6A). These findings were obtained despite the fact that our subjects had consumed a standardized diet that provided ample dietary protein ( 70 g protein) throughout the day. The latter underlines the efficacy of nighttime protein provision to modulate muscle protein synthesis. The application of intrinsically $L-\left[1-{ }^{13} \mathrm{C}\right]$-phenylalanine labeled casein, with an enrichment level of up to $40 \mathrm{MPE},{ }^{18}$ allows us to also assess the incorporation of the absorbed $\mathrm{L}-\left[1-{ }^{13} \mathrm{C}\right]$-phenylalanine into skeletal muscle protein. In the PRO experiment, muscle protein bound $\mathrm{L}-\left[1-{ }^{13} \mathrm{C}\right]$-phenylalanine had increased substantially, which translated into a fractional mixed muscle protein synthesis rate of $0.058 \pm 0.006 \% \cdot h^{-1}$ (Figure $5.6 \mathrm{~B}$ ). The latter provides direct evidence that dietary protein administered during sleep is not only adequately digested and absorbed, but is also effectively used for de novo muscle protein synthesis.

Evidence for proper nocturnal protein digestion and absorption as well as subsequent de novo muscle protein synthesis in vivo may be of clinical relevance. The concept of overnight protein provision can be translated to more practical dietary interventions. For example, specifically designed proteins or pre-bedtime protein meals might be applied to allow dietary protein provision throughout overnight sleep. In the present study, the large amounts of dietary protein ( $40 \mathrm{~g}$ ) administered during sleep were well received and did not cause any gastrointestinal disturbances or nausea. In fact, none of the subjects woke up during or immediately after administration of the protein (or placebo) solution. It could be speculated that overnight protein provision might 
modulate food intake during the subsequent day(s). Though beyond the scope of the study, we assessed hunger levels prior to breakfast. ${ }^{39}$ Lower hunger ratings were reported when protein was provided during sleep. However, the latter did not seem to affect energy and/or protein intake during subsequent breakfast. So far, the present study suggests that it is possible to expand the window for nutritional support by protein provision during the night. Consequently, future research should investigate whether nighttime protein provision could represent a feasible concept to attenuate muscle mass loss in various clinical conditions, ${ }^{40,41}$ such as (post-surgical) muscle wasting ${ }^{42-44}$ and cachexia in post-cancer, ${ }^{45,46}$ chronic obstructive pulmonary disease ${ }^{47}$ and cardiac disease. ${ }^{48-50}$ The specific nutritional requirements and practical implications in such clinical subpopulations raise numerous interesting questions.

In conclusion, this study proves that protein administration during overnight sleep is followed by proper dietary protein digestion and absorption kinetics, thereby increasing plasma amino acid availability throughout the night. An increase in overnight plasma amino acid availability stimulates muscle protein synthesis during sleep and improves overnight whole-body protein balance in elderly males. Nocturnal dietary protein administration may represent an effective nutritional intervention strategy to support muscle mass maintenance in both health and disease. 


\section{References}

1. Janssen I, Heymsfield SB, Ross R. Low relative skeletal muscle mass (sarcopenia) in older persons is associated with functional impairment and physical disability. J Am Geriatr Soc. 2002;50:889-96.

2. Koopman R, van Loon LJ. Aging, exercise, and muscle protein metabolism. J Appl Physiol. 2009;106:2040-8.

3. Evans WJ. What is sarcopenia? J Gerontol A Biol Sci Med Sci. 1995;50 Spec No:5-8.

4. Koopman R, Walrand S, Beelen M, Gijsen AP, Kies AK, Boirie $Y$, et al. Dietary protein digestion and absorption rates and the subsequent postprandial muscle protein synthetic response do not differ between young and elderly men. J Nutr. 2009;139:1707-13.

5. Volpi E, Sheffield-Moore M, Rasmussen BB, Wolfe RR. Basal muscle amino acid kinetics and protein synthesis in healthy young and older men. JAMA. 2001;286:1206-12.

6. Walrand S, Short KR, Bigelow ML, Sweatt AJ, Hutson SM, Nair KS. Functional impact of high protein intake on healthy elderly people. Am J Physiol Endocrinol Metab. 2008;295:E921-8.

7. Cuthbertson D, Smith K, Babraj J, Leese G, Waddell T, Atherton P, et al. Anabolic signaling deficits underlie amino acid resistance of wasting, aging muscle. FASEB J. 2005;19:422-4.

8. Volpi E, Ferrando AA, Yeckel CW, Tipton KD, Wolfe RR. Exogenous amino acids stimulate net muscle protein synthesis in the elderly. J Clin Invest. 1998;101:2000-7.

9. Boirie $\mathrm{Y}$, Dangin M, Gachon P, Vasson MP, Maubois JL, Beaufrere B. Slow and fast dietary proteins differently modulate postprandial protein accretion. Proc Natl Acad Sci U S A. 1997;94:14930-5.

10. Pennings B, Boirie Y, Senden JM, Gijsen AP, Kuipers H, van Loon $\sqcup$. Whey protein stimulates postprandial muscle protein accretion more effectively than do casein and casein hydrolysate in older men. Am J Clin Nutr. 2011;93:322-31.

11. Koopman R, Verdijk LB, Beelen M, Gorselink M, Kruseman AN, Wagenmakers AJ, et al. Co-ingestion of leucine with protein does not further augment post-exercise muscle protein synthesis rates in elderly men. Br J Nutr. 2008;99:571-80.

12. Rieu I, Balage M, Sornet C, Giraudet C, Pujos E, Grizard J, et al. Leucine supplementation improves muscle protein synthesis in elderly men independently of hyperaminoacidaemia. J Physiol. 2006;575: 305-15.

13. Beelen M, Tieland M, Gijsen AP, Vandereyt H, Kies AK, Kuipers $H$, et al. Coingestion of carbohydrate and protein hydrolysate stimulates muscle protein synthesis during exercise in young men, with no further increase during subsequent overnight recovery. J Nutr. 2008;138:2198-204.

14. Keller J, Groger G, Cherian L, Gunther B, Layer P. Circadian coupling between pancreatic secretion and intestinal motility in humans. Am J Physiol Gastrointest Liver Physiol. 2001;280:G273-8.

15. Furukawa Y, Cook IJ, Panagopoulos V, McEvoy RD, Sharp DJ, Simula M. Relationship between sleep patterns and human colonic motor patterns. Gastroenterology. 1994;107:1372-81.

16. Kumar D, Idzikowski C, Wingate DL, Soffer EE, Thompson P, Siderfin C. Relationship between enteric migrating motor complex and the sleep cycle. Am J Physiol. 1990;259:G983-90.

17. Boirie $\mathrm{Y}$, Fauquant J, Rulquin H, Maubois JL, Beaufrere B. Production of large amounts of [13C]leucineenriched milk proteins by lactating cows. J Nutr. 1995;125:92-8.

18. van Loon L, Boirie Y, Gijsen AP, Fauquant J, de Roos AL, Kies AK, et al. The production of intrinsically labeled milk protein provides a functional tool for human nutrition research. J Dairy Sci. 2009;92: 4812-22.

19. Report of the expert committee on the diagnosis and classification of diabetes mellitus. Diabetes Care. 2003;26 Suppl 1:S5-20.

20. Jones PR, Pearson J. Anthropometric determination of leg fat and muscle plus bone volumes in young male and female adults. J Physiol. 1969;204:63P-6P.

21. Raben A, Tagliabue A, Astrup A. The reproducibility of subjective appetite scores. $\mathrm{Br} \mathrm{J} \mathrm{Nutr}$. 1995; 73:517-30.

22. Abumrad NN, Rabin D, Diamond MP, Lacy WW. Use of a heated superficial hand vein as an alternative site for the measurement of amino acid concentrations and for the study of glucose and alanine kinetics in man. Metabolism. 1981;30:936-40. 
23. Bergstrom J. Percutaneous needle biopsy of skeletal muscle in physiological and clinical research. Scand J Clin Lab Invest. 1975;35:609-16.

24. van Eijk HM, Rooyakkers DR, Deutz NE. Rapid routine determination of amino acids in plasma by highperformance liquid chromatography with a 2-3 microns Spherisorb ODS II column. J Chromatogr. 1993;620:143-8.

25. Wolfe RR. Radioactive and Stable Isotope Tracers in Biomedicine: Principles and Practice of Kinetic Analysis New York: Wiley-Liss; 1992:480.

26. Biolo G, Tessari P, Inchiostro S, Bruttomesso D, Fongher C, Sabadin L, et al. Leucine and phenylalanine kinetics during mixed meal ingestion: a multiple tracer approach. Am J Physiol. 1992;262:E455-63.

27. Husek P. Amino acid derivatization and analysis in five minutes. FEBS Lett. 1991;280:354-6.

28. Dangin M, Guillet C, Garcia-Rodenas C, Gachon P, Bouteloup-Demange C, Reiffers-Magnani K, et al. The rate of protein digestion affects protein gain differently during aging in humans. J Physiol. 2003;549: 635-44.

29. Boirie Y, Gachon P, Corny S, Fauquant J, Maubois JL, Beaufrere B. Acute postprandial changes in leucine metabolism as assessed with an intrinsically labeled milk protein. Am J Physiol. 1996;271:E1083-91.

30. Short KR, Meek SE, Moller N, Ekberg K, Nair KS. Whole body protein kinetics using Phe and Tyr tracers: an evaluation of the accuracy of approximated flux values. Am J Physiol. 1999;276:E1194-200.

31. Zhang XJ, Chinkes DL, Wolfe RR. Measurement of muscle protein fractional synthesis and breakdown rates from a pulse tracer injection. Am J Physiol Endocrinol Metab. 2002;283:E753-64.

32. Katsanos CS, Kobayashi H, Sheffield-Moore M, Aarsland A, Wolfe RR. Aging is associated with diminished accretion of muscle proteins after the ingestion of a small bolus of essential amino acids. Am J Clin Nutr. 2005;82:1065-73.

33. Pannemans DL, Wagenmakers AJ, Westerterp KR, Schaafsma G, Halliday D. Effect of protein source and quantity on protein metabolism in elderly women. Am J Clin Nutr. 1998;68:1228-35.

34. Koopman R, Verdijk L, Manders RJ, Gijsen AP, Gorselink M, Pijpers E, et al. Co-ingestion of protein and leucine stimulates muscle protein synthesis rates to the same extent in young and elderly lean men. Am J Clin Nutr. 2006;84:623-32.

35. Bohe J, Low A, Wolfe RR, Rennie MJ. Human muscle protein synthesis is modulated by extracellular, not intramuscular amino acid availability: a dose-response study. J Physiol. 2003;552:315-24.

36. Dangin M, Boirie Y, Garcia-Rodenas C, Gachon P, Fauquant J, Callier P, et al. The digestion rate of protein is an independent regulating factor of postprandial protein retention. Am J Physiol Endocrinol Metab. 2001;280:E340-8.

37. Pennings B, Koopman R, Beelen M, Senden JM, Saris WH, van Loon LJ. Exercising before protein intake allows for greater use of dietary protein-derived amino acids for de novo muscle protein synthesis in both young and elderly men. Am J Clin Nutr. 2011;93:322-31.

38. Nair KS, Halliday D, Griggs RC. Leucine incorporation into mixed skeletal muscle protein in humans. Am J Physiol. 1988;254:E208-13.

39. Silverstone T, Schuyler D. The effect of cyproheptadine on hunger, calorie intake and body weight in man. Psychopharmacologia. 1975;40:335-40.

40. Klein S, Kinney J, Jeejeebhoy K, Alpers D, Hellerstein M, Murray M, et al. Nutrition support in clinical practice: review of published data and recommendations for future research directions. Summary of a conference sponsored by the National Institutes of Health, American Society for Parenteral and Enteral Nutrition, and American Society for Clinical Nutrition. Am J Clin Nutr. 1997;66:683-706.

41. Souba WW. Nutritional support. N Engl J Med. 1997;336:41-8.

42. Kavanagh $\mathrm{T}$, Yacoub $\mathrm{MH}$. Exercise training in patients after heart transplantation. Ann Acad Med Singapore. 1992;21:372-8.

43. Huckleberry Y. Nutritional support and the surgical patient. Am J Health Syst Pharm. 2004;61:671-82.

44. Rolandelli RH, Ullrich JR. Nutritional support in the frail elderly surgical patient. Surg Clin North Am. 1994;74:79-92.

45. Yeatman TJ. Nutritional support for the surgical oncology patient. Cancer Control. 2000;7:563-5.

46. Norton JA, Peacock JL, Morrison SD. Cancer cachexia. Crit Rev Oncol Hematol. 1987;7:289-327.

47. Schols AM, Wouters EF. Nutritional abnormalities and supplementation in chronic obstructive pulmonary disease. Clin Chest Med. 2000;21:753-62.

48. Azhar G, Wei JY. Nutrition and cardiac cachexia. Curr Opin Clin Nutr Metab Care. 2006;9:18-23. 
49. Freeman LM, Roubenoff R. The nutrition implications of cardiac cachexia. Nutr Rev. 1994;52:340-7.

50. Paccagnella A, Calo MA, Caenaro G, Salandin V, Jus P, Simini G, et al. Cardiac cachexia: preoperative and postoperative nutrition management. JPEN J Parenter Enteral Nutr. 1994;18:409-16. 


\section{Chapter}

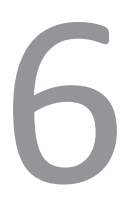

Neuromuscular electrical stimulation increases postprandial muscle protein accretion during overnight sleep

Marlou L. Dirks*, Bart B.L. Groen*, Rinske Franssen, Janneau van Kranenburg, Luc J.C. van Loon *These authors contributed equally to this work

Submitted 


\section{Abstract}

\section{Background}

Short periods of skeletal muscle disuse, due to illness or injury, result in substantial skeletal muscle atrophy. Recently, we showed that both neuromuscular electrical stimulation (NMES) as well as dietary protein ingestion prior to sleep represent effective strategies to stimulate muscle protein synthesis rates. In this study we test our hypothesis that NMES can augment the impact of protein ingestion prior to sleep to stimulate overnight muscle protein accretion.

\section{Methods}

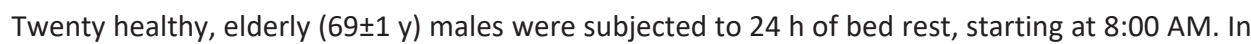
the evening, subjects were subjected to a 70 min one-legged NMES protocol, while the other leg served as non-stimulated control (CON). Immediately following NMES, a drink containing $40 \mathrm{~g}$ intrinsically L- $\left[1-{ }^{13} \mathrm{C}\right]$-phenylalanine labeled protein was ingested prior to sleep. Repeated blood samples were taken throughout the night, and muscle biopsies were obtained from both legs in the evening and on the following morning ( $8 \mathrm{~h}$ after protein ingestion) to assess dietary protein derived $\mathrm{L}-\left[1-{ }^{13} \mathrm{C}\right]$-phenylalanine enrichment in myofibrillar protein.

\section{Results}

Plasma phenylalanine concentrations and $\mathrm{L}-\left[1{ }^{13} \mathrm{C}\right]-$ phenylalanine enrichments increased significantly following protein ingestion and remained elevated for up to 6 hours $(P<0.05)$. During overnight sleep, myofibrillar protein-bound $\mathrm{L}-\left[1-{ }^{13} \mathrm{C}\right]$-phenylalanine enrichments increased to a greater extent in the stimulated compared with the control leg $(0.0344 \pm 0.0019$ vs $0.0297 \pm 0.0016$ $\mathrm{MPE}$, respectively; $\mathrm{P}<0.01)$, representing $18 \pm \%$ greater incorporation in the NMES leg.

\section{Conclusions}

The combined application of NMES with protein feeding prior to sleep increases overnight muscle protein accretion in elderly men. 


\section{Introduction}

Aging is associated with a progressive loss of skeletal muscle mass, often referred to as sarcopenia. ${ }^{1}$ The loss of muscle mass reduces strength, impairs functional capacity, and increases the risk of developing chronic metabolic diseases. ${ }^{2}$ Sarcopenia is facilitated by a combination of factors, which include a reduced sensitivity to anabolic stimuli, ${ }^{3,4}$ a less than optimal diet, ${ }^{5}$ and a more sedentary lifestyle. ${ }^{5}$ It has recently been suggested that short successive periods of reduced physical activity, due to illness or injury, may form a key factor responsible for the progressive loss of muscle tissue in the older population. ${ }^{6}$ To attenuate muscle loss during such short periods of bed rest in the elderly population, various interventional strategies have been suggested. ${ }^{7}$

The ingestion of dietary protein directly stimulates muscle protein synthesis. ${ }^{8}$ Aging is associated with an impaired muscle protein synthetic response to feeding, previously coined 'anabolic resistance'. ${ }^{9}$ Numerous research groups are now looking for effective dietary strategies to compensate for this anabolic resistance by increasing the amount of dietary protein ingested, ${ }^{10}$ changing the protein source applied, ${ }^{11,12}$, co-ingesting additional free leucine ${ }^{13,14}$ and altering the timing of protein ingestion. ${ }^{15}$ Rather than improving the muscle protein synthetic response to the ingestion of a single meal, we investigated the possibility of increasing overnight muscle protein accretion by dietary protein administration prior to and/or during sleep. ${ }^{16,17}$ Our work shows that protein ingestion prior to sleep may represent an effective strategy to stimulate overnight muscle protein synthesis, thereby providing a practical strategy to attenuate muscle loss during periods characterized by anabolic resistance.

Physical activity is severely restricted during a period of bed rest due to illness or injury. The loss of physical activity reduces the muscle protein synthetic response to protein feeding. ${ }^{18,19}$ Neuromuscular electrical stimulation (NMES) represents an exercise mimetic to allow muscle contractions to occur and may be used to attenuate disuse related anabolic resistance. In agreement, a single session of NMES has been shown to increase muscle protein synthesis rates. ${ }^{20}$ Furthermore, NMES has been applied successfully to prevent muscle atrophy during 5 days of limb immobilization. ${ }^{21}$ We hypothesize that NMES can further stimulate the muscle protein synthetic response to protein feeding, resulting in greater postprandial muscle protein accretion.

We hypothesized that combining NMES with dietary protein feeding prior to sleep could further stimulate overnight muscle protein accretion. If supported, the combined application of NMES and protein feeding prior to sleep may be used to attenuate muscle loss during short periods of hospitalization in a compromised elderly population. To test our hypothesis, we performed unilateral NMES in the evening after a day of bed rest in 20 healthy elderly males. Subjects ingested specifically produced intrinsically L-[1-13 C]-phenylalanine labeled protein ${ }^{8}$ to assess overnight muscle protein accretion. By taking blood samples throughout the night and muscle biopsies before and after sleep from both legs we assessed overnight muscle protein accretion in the 
stimulated and non-stimulated leg. This is the first study to show that the combined application of NMES and protein feeding prior to sleep stimulates overnight muscle protein accretion, thereby providing a novel interventional strategy to prevent or attenuate muscle loss during short periods of hospitalization in older subjects.

\section{Materials and methods}

\section{Subjects}

Twenty healthy, elderly males (age: $69 \pm 1$ y) were included in the present study that was approved by the Medical Ethical Committee of the Maastricht University Medical Centre in accordance with the Declaration of Helsinki. Prior to the study, subjects completed a routine medical screening and general health questionnaire to ensure their suitability to participate. Exclusion criteria were: BMI below 18.5 or above 30 $\mathrm{kg} \cdot \mathrm{m}^{2}$, type 2 diabetes mellitus (determined by oral glucose tolerance testing), severe cardiac problems, and implantation of a pacemaker and/or implantable cardioverterdefibrillator (ICD). Furthermore, subjects who had performed structured and prolonged resistance type exercise training during the 6 months prior to the study were excluded. All subjects were informed of the nature and possible risks of the experimental procedures, before their written informed consent was obtained.

\section{Pretesting}

Following an overnight fast, the subjects arrived at the laboratory at $8.00 \mathrm{AM}$ in the morning of the day of pretesting by car or public transportation. A catheter (Baxter BV, Utrecht, the Netherlands) was inserted into an antecubital vein for venous blood sampling. All participants performed an oral glucose tolerance test before inclusion in the study. Plasma glucose concentrations were measured to determine oral glucose tolerance and/or the presence of type 2 diabetes according to 2006 American Diabetes Association guidelines. ${ }^{22}$ Leg volume was measured by anthropometry as described by Jones and Pearson. ${ }^{23}$ Directly after the oral glucose tolerance test, body weight, body composition, and bone mineral content were measured with Dual Energy X-Ray Absorptiometry (DXA; Lunar Prodigy Advance; GE Health Care, Madison, WI, USA). The system's software package (en-CORE 2005, version 9.15.00) was used to determine whole body and regional lean and fat mass. Finally, all subjects performed a short session of neuromuscular electrical stimulation (NMES) to familiarize them with the intervention and to determine the required stimulation intensity for full muscle contractions during testing. 


\section{Diet and physical activity prior and during testing}

All volunteers were instructed to refrain from any vigorous physical activity and to keep their diet as constant as possible 3 days prior to the trial. On the day of the experiment, subjects consumed a standardized breakfast, mid-morning snack, lunch, mid-afternoon snack, and dinner while being in the hospital. The standardized diet (3 meals and 2 snacks) provided $7.7 \mathrm{MJ}$, with 60\% energy (En\%) provided by carbohydrate, $22 \mathrm{En} \%$ provided by fat, and $18 \mathrm{En} \%$ provided by protein. Total protein intake averaged $1.35 \pm 0.02 \mathrm{~g} \cdot \mathrm{kg}^{-1}$ bodyweight during the test day.

\section{Study protocol}

After inclusion, one of the subjects' legs was randomly allocated to receive neuromuscular electrical stimulation (NMES), while the other leg served as a (nonstimulated) control (CON) leg. The experimental protocol is depicted in Figure 6.1. At $8.00 \mathrm{AM}$, following an overnight fast, subjects arrived at the laboratory where a first blood sample was obtained by venipuncture to determine fasting plasma glucose and insulin levels. During the rest of the day, subjects remained in a supine position in their hospital bed. At 7:30 PM, A Teflon catheter was inserted in a dorsal hand vein for blood sampling and a first blood sample $(8 \mathrm{~mL})$ was drawn at 8:00 PM. At night, a $30 \mathrm{~cm}$ extension line was connected to the cannula to allow overnight blood sampling without waking the subjects. A 70 min NMES protocol was performed at 9:30 PM. Immediately following the NMES, a muscle biopsy was collected from the vastus lateralis muscle $(\mathrm{t}=0$ h) from both legs (NMES and CON). Directly after the biopsy procedure, subjects received the test drink, consisting of $40 \mathrm{~g}$ intrinsically $\left[1-{ }^{13} \mathrm{C}\right]$-phenylalanine labeled casein protein dissolved in a total volume of $450 \mathrm{~mL}$. After consuming the test drink, subjects prepared to go to sleep. Blood samples $(8 \mathrm{~mL})$ were collected at $\mathrm{t}=0,1 / 2,1,2,4$, 6 and $8 \mathrm{~h}$ after protein feeding. The next morning, directly after waking up, muscle biopsies from both legs were taken from a new incision, proximal from the first incision, at $\mathrm{t}=8 \mathrm{~h}$ after protein feeding.

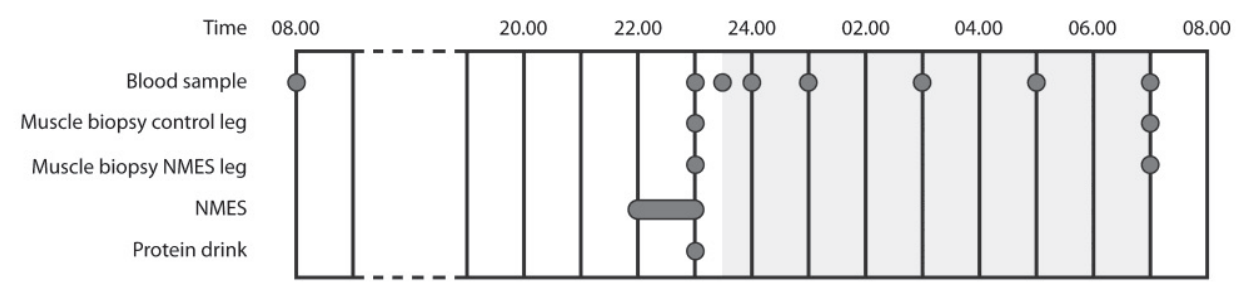

Figure 6.1 Outline of the experimental protocol. NMES: neuromuscular electrical stimulation. 
Venous blood samples were collected into EDTA-containing tubes and centrifuged at $1000 \mathrm{~g}$ for $10 \mathrm{~min}$ at $4^{\circ} \mathrm{C}$. Aliquots of plasma were frozen in liquid nitrogen and stored at $-80^{\circ} \mathrm{C}$ until further analysis. Muscle biopsy samples were obtained from the middle region of the vastus lateralis muscle, $15 \mathrm{~cm}$ above the patella and $\sim 3 \mathrm{~cm}$ below entry through the fascia using the percutaneous needle biopsy technique. ${ }^{24}$ Muscle biopsy samples were carefully dissected and freed from any visible non-muscle material and then immediately frozen in liquid nitrogen and stored at $-80^{\circ} \mathrm{C}$ until further analysis.

\section{Neuromuscular electrical stimulation}

All subjects performed a single session of neuromuscular electrical stimulation (NMES) and a simultaneous sham session (CON) at the opposite leg at 9:30 PM. During this session, subjects were lying supine and electrodes were placed on the distal part at the muscle belly of the $m$. rectus femoris and the $m$. vastus lateralis, and at the inguinal area of both muscles. Stimulation was provided by an Enraf-Nonius TensMed S84 stimulation device (Enraf-Nonius, Rotterdam, the Netherlands) and four, $2 \mathrm{~mm}$-thick, self-adhesive electrodes $(50 \times 50 \mathrm{~mm})$, discharging biphasic symmetric rectangularwave pulses. The NMES protocol comprised of a warm-up phase ( $5 \mathrm{~min}, 5 \mathrm{~Hz}, 250 \mu \mathrm{s}$ ), a stimulation phase $(60 \mathrm{~min}, 100 \mathrm{~Hz}, 400 \mu \mathrm{s}, 5 \mathrm{~s}$ on $(0.75 \mathrm{~s}$ rise, $3.5 \mathrm{~s}$ contraction, $0.75 \mathrm{~s}$ fall) and $10 \mathrm{~s}$ off), and a cooling-down phase ( $5 \mathrm{~min}, 5 \mathrm{~Hz}, 250 \mu \mathrm{s})$. Subjects set the intensity of the stimulation to a level at which full contractions of $m$. quadriceps femoris were both visible and palpable, and the heel began to slightly lift. This protocol was based on our previous work ${ }^{25}$ demonstrating an increase in muscle protein synthesis during a $6 \mathrm{~h}$ period following a single bout of NMES. The same protocol was also used in a previous study showing that high-frequency $(>60 \mathrm{~Hz})$, high pulse duration $(>250 \mu \mathrm{s})$ NMES is effective in preventing muscle atrophy during short-term muscle disuse. ${ }^{21}$ Subjects were encouraged to increase the intensity of the stimulation during the entire session to provide a 'progressive' stimulus. The maximal intensity of the 70 min NMES session averaged $36.2 \pm 1.8 \mathrm{~mA}$, whereas the average intensity across all sessions and all subjects was $27.3 \pm 1.3 \mathrm{~mA}$. All subjects completed the NMES protocol.

\section{Intrinsically labeled protein}

Intrinsically L-[1- $\left.{ }^{13} \mathrm{C}\right]$-phenylalanine-labeled casein protein was obtained by infusing a Holstein cow with large quantities of $\mathrm{L}-\left[1-{ }^{13} \mathrm{C}\right]$-phenylalanine, collecting milk, and purifying the casein fraction as described previously. ${ }^{26}$ The L-[1- $\left.{ }^{13} \mathrm{C}\right]$-phenylalanine enrichment in the casein fraction averaged 35.8 mole percent excess (MPE). The casein protein met all chemical and bacteriological specifications for human consumption. Subjects received a total beverage volume of $450 \mathrm{~mL}$, which provided $40 \mathrm{~g}$ casein protein. Drinks were flavored by adding $2 \mathrm{~mL}$ vanilla flavor (Givaudan, Naarden, the Netherlands) per L beverage. 


\section{Plasma analyses}

Plasma glucose (Uni Kit III, 07367204, Roche, Basel, Switzerland) concentrations were analyzed with the COBAS-FARA semi-automatic analyzer (Roche). Insulin was analyzed by radio-immunoassay (Insulin RIA kit, LINCO Research Inc., St. Charles, MO, USA). Plasma amino acid concentrations and enrichments were determined by GC-MS (Agilent 7890A GC/5975C; MSD, Little Falls, DE, USA). Specifically, internal standards of $\left[\mathrm{U}-{ }^{13} \mathrm{C}_{6}\right]$-leucine, $\left[\mathrm{U}-{ }^{13} \mathrm{C}_{9}{ }^{15} \mathrm{~N}\right]$-phenylalanine, and $\left[\mathrm{U}-{ }^{13} \mathrm{C}_{9}{ }^{15} \mathrm{~N}\right]$-tyrosine were added to the samples. The plasma was deproteinized on ice with dry 5-sulfosalicylic acid. Free amino acids were purified using cation exchange AG 50W-X8 resin (mesh size: 100-200, ionic form: hydrogen (Bio-Rad Laboratories, Hercules, CA, USA)) columns. The free amino acids were converted to their tert-butyl dimethylsilyl (TBDMS) derivative before analysis by GC-MS. The amino acid concentrations were determined using electron impact ionization by monitoring ions at mass/charge $(\mathrm{m} / \mathrm{z}) 302$ and 308 for unlabeled and $\left[\mathrm{U}^{13} \mathrm{C}_{6}\right]$-leucine respectively, 336 and 346 for unlabeled and $\left[\mathrm{U}^{13} \mathrm{C}_{9}{ }^{15} \mathrm{~N}\right]-$ phenylalanine, respectively. For $L-\left[1-{ }^{13} \mathrm{C}\right]$-phenylalanine, $\mathrm{m} / \mathrm{z} 336(\mathrm{~m}+0)$ and $337(\mathrm{~m}+1)$ were monitored. Standard regression curves were applied from a series of known standard enrichment values against the measured values to assess the linearity of the mass spectrometer and to account for any isotope fractionation that may have occurred during the analysis. Phenylalanine enrichments were corrected for the presence of the ${ }^{13} \mathrm{C}$ isotopes. Standard regression curves were applied in all isotopic enrichment analyses to assess the linearity of the mass spectrometer and to control for the loss of tracer. Enrichments (MPE) were corrected for the natural abundance of ${ }^{13} \mathrm{C}$ phenylalanine. ${ }^{27}$

\section{Muscle analyses}

Myofibrillar protein enriched fractions were extracted from wet muscle tissue as described previously. ${ }^{28}$ In short, $50 \mathrm{mg}$ wet muscle tissue was manually homogenized on ice using a Teflon pestle in a standard extraction buffer, after which the samples were centrifuged and the supernatants containing sarcoplasmic proteins were removed. In an additional step, the collagen-containing supernatant was removed. The remaining myofibrillar fraction was purified and hydrolyzed, such that the free amino acids remained and could be dried. The enrichment of the derivative was measured by GC-C-IRMS (MAT 253; Thermo Scientific, Bremen, Germany) by using a DB5DB5-MScolumn (no. 122122-5532; Agilent J+W, USA), GC Isolink, and monitoring of ion masses 44, 45 and 46. By establishing the relationship between the enrichment of a series of $\mathrm{L}-\left[1-{ }^{13} \mathrm{C}\right]$-phenylalanine standards of variable enrichment, the myofibrillar proteinbound enrichment of phenylalanine was determined. Standard regression curves were applied to assess the linearity of the mass spectrometer and to control for the loss of tracer. Muscle protein deposition from the ingested casein over the $8 \mathrm{~h}$ postprandial 
period was expressed in the relative increase of $L-\left[1-{ }^{13} \mathrm{C}\right]$-phenylalanine enrichment in muscle tissue.

\section{Statistics}

All data are expressed as means \pm SEM. Differences in baseline leg values (i.e. NMES vs. CON) were determined using a paired, two-tailed Student's t-Test. Differences in protein-bound L-[1- $\left.{ }^{13} \mathrm{C}\right]$-phenylalanine enrichments and FSR between the NMES and CON legs after $8 \mathrm{~h}$ incorporation were analyzed using a paired-samples t-test. In case of a significant effect, a post hoc test with Bonferroni correction was used to locate significant differences. Statistical significance was set at $P<0.05$. All calculations were performed by using the SPSS statistics 22 software package (SPSS Inc., Chicago, IL, USA).

\section{Results}

\section{Plasma analyses}

Plasma insulin concentrations are presented in Figure 6.2. Provision of intrinsically labeled casein resulted in a small but significant increase in circulating plasma insulin concentrations (time effect; $P<0.001$ ). Plasma insulin concentrations averaged 20.6 \pm 2.4 $\mathrm{mU} \cdot \mathrm{L}^{-1}$ during the overnight period, and reached peak values of $34.7 \pm 5.9 \mathrm{mU} \cdot \mathrm{L}^{-1}(P<0.01$ versus $\mathrm{t}=0$ ). Plasma glucose concentrations declined following protein ingestion (time effect; $P<0.001)$, and became significantly different from baseline values from $\mathrm{t}=2 \mathrm{~h}$ onwards $(P<0.05)$. Overnight plasma glucose concentrations averaged $5.6 \pm 0.1 \mathrm{mmol} \cdot \mathrm{L}^{-1}$.

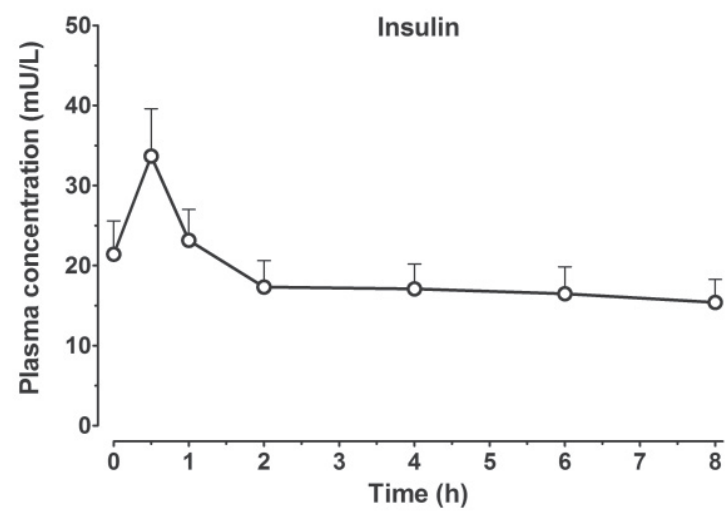

Figure 6.2 Plasma insulin concentrations, expressed as means \pm SEM. Data were analyzed with repeated measures ANOVA. Plasma insulin: time effect, $P<0.001$. 
Figure 6.3 depicts plasma leucine and phenylalanine concentrations during the overnight period. At the start of the experiment, fasting plasma leucine and phenylalanine concentrations averaged $133 \pm 4$ and $57 \pm 1 \mu \mathrm{M}$, respectively. In the evening, prior to ingestion of the protein drink, concentrations averaged $138 \pm 7$ and $64 \pm 1 \mu \mathrm{M}$, respectively. Directly after protein ingestion ( 10:30 PM), plasma leucine and phenylalanine concentrations increased rapidly (time effects; $P<0.001$ ), and remained elevated throughout most of the night. Peak plasma leucine $(284 \pm 11 \mu \mathrm{M})$ and phenylalanine $(89 \pm 3 \mu \mathrm{M})$ concentrations were reached at $182 \pm 19$ and $155 \pm 25$ min after protein ingestion, respectively.
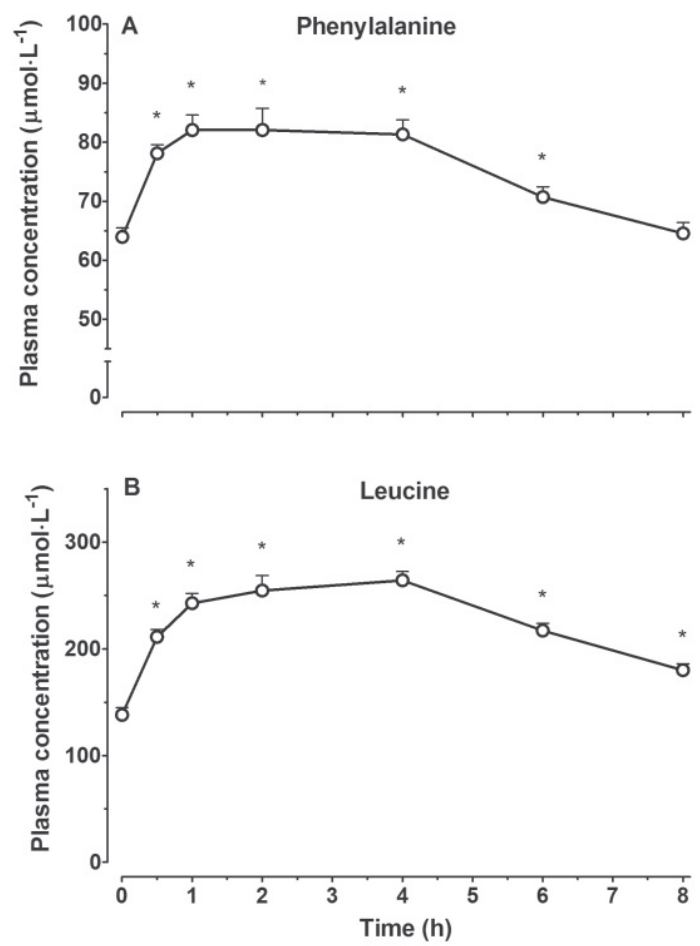

Figure 6.3 Plasma leucine (A) and phenylalanine (B) concentrations. Values are expressed as means \pm SEM. Data were analyzed with repeated measures ANOVA. Plasma leucine: time effect, $P<0.001$; plasma phenylalanine: time effect, $P<0.001$; ${ }^{*}$ Significantly different from baseline value.

\section{Stable isotope tracer analyses}

Plasma $\left[1-{ }^{13} \mathrm{C}\right]$-phenylalanine enrichments over time are presented in Figure 6.4. Plasma $\left[1-{ }^{13} \mathrm{C}\right]$-phenylalanine enrichments increased rapidly after ingestion of the intrinsically $\mathrm{L}-\left[1-{ }^{13} \mathrm{C}\right]$-phenylalanine labeled casein protein, with plasma $\mathrm{L}-\left[1-{ }^{13} \mathrm{C}\right]-$ phenylalanine enrichment levels reaching peak values of $12.2 \pm 0.5$ MPE at $174 \pm 16 \mathrm{~min}$ 
after protein consumption. Plasma $\left[1-{ }^{13} \mathrm{C}\right]$-phenylalanine enrichments remained significantly elevated for the remaining night (time effect; $P<0.001$ ).

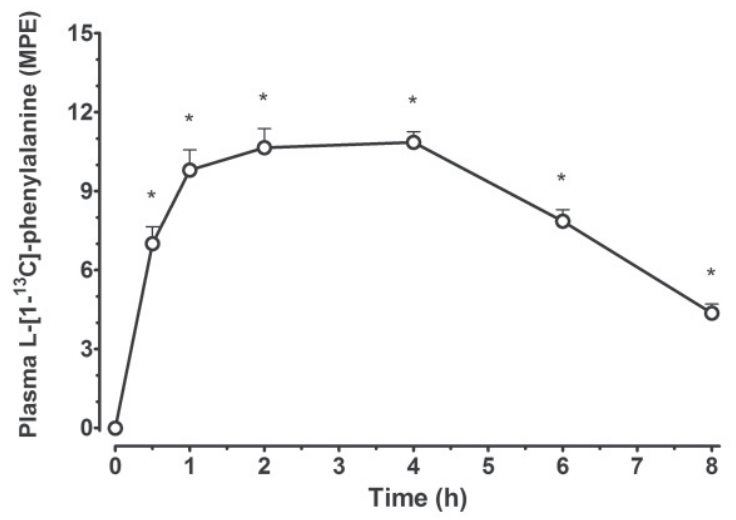

Figure 6.4 Plasma L- $\left[1-{ }^{13} \mathrm{C}\right]$-phenylalanine enrichments. Values are expressed as means \pm SEM. Data were analyzed with repeated measures ANOVA. Plasma phenylalanine: time effect, $P<0.001$; * Significantly different from baseline values.

Myofibrillar muscle protein bound L- $\left[1-{ }^{13} \mathrm{C}\right]$-phenylalanine enrichments are presented in Figure 6.5. Muscle tissue analyses were performed on muscle biopsy samples collected before, and $8 \mathrm{~h}$ after ingestion of the intrinsically L-[1- $\left.{ }^{13} \mathrm{C}\right]$-phenylalanine labeled casein. After the $8 \mathrm{~h}$ overnight period, L-[1- $\left.{ }^{13} \mathrm{C}\right]$-phenylalanine enrichments had increased up to $0.0297 \pm 0.0016 \mathrm{MPE}$ in the CON leg and $0.0344 \pm 0.0019 \mathrm{MPE}$ in the NMES leg, $(P<0.01)$, representing $18 \pm 6 \%$ greater enrichments in the NMES leg compared with the CON leg.

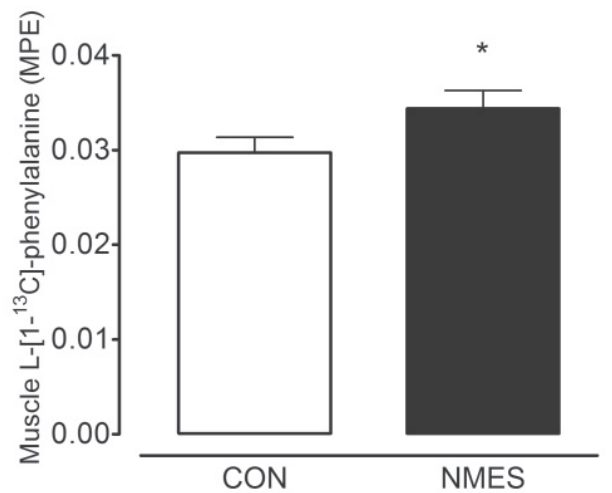

Figure 6.5 Muscle tissue L-[1- $\left.{ }^{13} \mathrm{C}\right]$-phenylalanine enrichments. Values are expressed as means $\pm S E M$. Data were analyzed with a paired student's t-test. * Significantly different from the control leg $(P<0.01)$. 


\section{Discussion}

The present study demonstrates for the first time that ingestion of $40 \mathrm{~g}$ casein protein prior to sleep leads to overnight de novo myofibrillar protein accretion in healthy, elderly men after a day of bed rest. The overnight accretion of newly formed muscle protein was augmented when neuromuscular electrical stimulation (NMES) was applied prior to protein ingestion.

Short periods of bed rest or immobilization due to injury or illness lead to substantial loss of skeletal muscle mass and strength. ${ }^{29-32}$ The decline in muscle tissue has been, at least partly, attributed to a blunted muscle protein synthetic response to food ingestion. ${ }^{33}$ This so-called anabolic resistance to protein ingestion can be compensated for by changing the dietary protein source, ${ }^{34,35}$ the amount of ingested protein ${ }^{36-38}$ and/or the distribution of protein intake throughout the day. ${ }^{39-41}$ Recently, we introduced the concept of stimulating overnight muscle protein synthesis by providing dietary protein during sleep in older males. ${ }^{16}$ Intragastric protein administration via a nasogastric tube during overnight sleep was followed by proper dietary protein digestion and absorption, that increased plasma amino acid availability and stimulated de novo muscle protein synthesis in healthy elderly males. ${ }^{16}$ In the current study, $40 \mathrm{~g}$ casein protein was ingested prior to sleep to test the concept of nighttime protein feeding in a more practically applicable manner. We show that pre-sleep ingestion of intrinsically $\mathrm{L}-\left[1{ }^{13} \mathrm{C}\right]$-phenylalanine labeled casein leads to a substantial postprandial rise in circulating plasma phenylalanine concentrations (Figure 6.3) and L-[1- $\left.{ }^{13} \mathrm{C}\right]-$ phenylalanine enrichments (Figure 6.4). The increase in plasma L- $\left[1-{ }^{13} \mathrm{C}\right]$-labeled phenylalanine clearly demonstrates that protein ingested prior to sleep is followed by proper digestion and absorption throughout the remainder of the night. Dietary protein derived amino acids were subsequently used for de novo myofibrillar protein synthesis as evidenced by the increase in myofibrillar protein bound L- $\left[1-{ }^{13} \mathrm{C}\right]$-phenylalanine enrichment in both legs in the $8 \mathrm{~h}$ following protein ingestion (Figure 6.5). The results of our study are in line with our previous findings and show that protein ingestion prior to sleep leads to proper protein digestion, amino acid absorption and net myofibrillar protein accretion throughout overnight sleep, ${ }^{16}$ and demonstrate that protein ingestion prior to sleep forms a practical and effective nutritional strategy to stimulate overnight muscle protein accretion.

Besides dietary protein ingestion, physical activity is a key anabolic stimulus that is required to preserve skeletal muscle mass. In a clinical setting, lack of sufficient physical activity causes anabolic resistance, ${ }^{33}$ resulting in rapid muscle loss. ${ }^{3,42,43}$ Recently we introduced neuromuscular electrical stimulation (NMES) as a surrogate for physical activity to increase the sensitivity of skeletal muscle tissue to the anabolic properties of protein administration ${ }^{44}$ and, as such, to attenuate muscle mass loss during a short period of immobilization. ${ }^{21}$ We hypothesized that NMES performed in the evening sensitizes skeletal muscle tissue to the anabolic properties of overnight protein feeding. 
In the present study, we electrically stimulated one leg, whereas the other leg was sham stimulated. This means that electrodes and wiring were applied to both legs but only one leg was actually electrically stimulated. After protein feeding, the stimulated leg showed an $18 \pm 6 \%$ greater increase in muscle protein bound L-[1- $\left.{ }^{13} \mathrm{C}\right]$-phenylalanine enrichment when compared with the control leg $(0.0344 \pm 0.0019$ vs $0.0297 \pm 0.0016$, respectively) assessed over 8 hours of subsequent sleep $(P<0.01$; Figure 6.5$)$. NMES effectively increased the sensitivity of the skeletal muscle tissue to protein feeding with more of the ingested protein being directed towards de novo muscle protein accretion during overnight sleep.

NMES has been proposed as an interventional strategy that can be used to evoke involuntary muscle contraction during muscle disuse, when individuals experience difficulties performing voluntary muscle contraction. The combined application of NMES and protein feeding prior to sleep may be of particular relevance in more clinically compromised individuals. An interesting population that could benefit greatly from such an intervention are clinically compromised elderly subjects that are hospitalized for a short period following a fall and/or a fracture. Most elderly individuals have difficulty regaining skeletal muscle mass after a short period of disuse, ${ }^{45}$ which impairs rehabilitation and contributes greatly to the development of frailty. Therefore, interventional strategies that can preserve skeletal muscle mass during a short period of muscle disuse are of paramount importance. From a practical point of view, the use of NMES has been shown to be both applicable and feasible during muscle disuse. In all studies performed in our laboratory, ${ }^{21,20}$ the treatment was well tolerated and no contra-indications or side effects were observed. Furthermore, the costs associated with NMES are relatively low, and hospital staff can easily apply the technique. Long-term effects of this treatment on muscle mass remain to be investigated, but we expect our results to be applicable for bedridden patients as we have even observed muscle mass preservation following the application of NMES in a setting of accelerated muscle loss in comatose patients. ${ }^{46}$

In conclusion, this is the first study to show that protein ingestion prior to sleep represents an effective interventional strategy to stimulate overnight skeletal muscle protein accretion in vivo in healthy, older men. The application of NMES in the evening can further augment postprandial muscle protein accretion following protein ingestion prior to sleep. The application of NMES combined with protein ingestion prior to sleep represents a feasible strategy to optimize overnight muscle protein accretion, and may be of great clinical benefit to attenuate muscle loss in clinically compromised individuals. 


\section{References}

1. Koopman R, and van Loon L. Aging, exercise, and muscle protein metabolism. J Appl Physiol 2009;106:2040-8.

2. Evans W. What is sarcopenia? J Gerontol A Biol Sci Med Sci. 1995;50 Spec No:5-8.

3. Cuthbertson D, Smith K, Babraj J, Leese G, Waddell T, Atherton P, Wackerhage H, Taylor PM, and Rennie MJ. Anabolic signaling deficits underlie amino acid resistance of wasting, aging muscle. FASEB J. 2005; 19:422-4.

4. Kumar D, Idzikowski C, Wingate DL, Soffer EE, Thompson P, and Siderfin C. Relationship between enteric migrating motor complex and the sleep cycle. Am J Physiol 1990;259:G983-90.

5. Evans WJ. Protein nutrition, exercise and aging. J Am Coll Nutr 2004;23:601S-9S.

6. Wall BT, Dirks ML, and van Loon LJ. Skeletal muscle atrophy during short-term disuse: implications for age-related sarcopenia. Ageing Res Rev 2013;12:898-906.

7. Breen L, and Phillips S. Skeletal muscle protein metabolism in the elderly: Interventions to counteract the 'anabolic resistance' of ageing. Nutr Metab 2011;8:68.

8. van Loon L, Boirie Y, Gijsen A, Fauquant J, de Roos A, Kies A, Lemosquet S, Saris W, and Koopman R. The production of intrinsically labeled milk protein provides a functional tool for human nutrition research. J Dairy Sci 2009;92:4812-22.

9. Burd NA, Gorissen SH, and van Loon LJ. Anabolic resistance of muscle protein synthesis with aging. Exerc Sport Sci Rev 2013;41:169-73.

10. Volpi E, Ferrando AA, Yeckel CW, Tipton KD, and Wolfe RR. Exogenous amino acids stimulate net muscle protein synthesis in the elderly. J Clin Invest 1998;101:2000-7.

11. Boirie Y, Dangin M, Gachon P, Vasson MP, Maubois JL, and Beaufrere B. Slow and fast dietary proteins differently modulate postprandial protein accretion. Proc Natl Acad Sci U S A 1997;94:14930-5.

12. Pennings B, Boirie $Y$, Senden JM, Gijsen AP, Kuipers $H$, and van Loon $\amalg$. Whey protein stimulates postprandial muscle protein accretion more effectively than do casein and casein hydrolysate in older men. Am J Clin Nutr 2011;93:322-31.

13. Koopman R, Verdijk LB, Beelen M, Gorselink M, Kruseman AN, Wagenmakers AJ, Kuipers $H$, and van Loon $\amalg$. Co-ingestion of leucine with protein does not further augment post-exercise muscle protein synthesis rates in elderly men. Br J Nutr 2008;99:571-80.

14. Rieu I, Balage M, Sornet C, Giraudet C, Pujos E, Grizard J, Mosoni L, and Dardevet D. Leucine supplementation improves muscle protein synthesis in elderly men independently of hyperaminoacidaemia. J Physiol 2006;575:305-15.

15. Esmarck B, Andersen J, Olsen S, Richter E, Mizuno M, and Kjaer M. Timing of postexercise protein intake is important for muscle hypertrophy with resistance training in elderly humans. J Physiol 2001;535: 301-11.

16. Groen BB, Res PT, Pennings B, Hertle E, Senden JM, Saris WH, and van Loon LJ. Intragastric protein administration stimulates overnight muscle protein synthesis in elderly men. Am J Physiol Endocrinol Metab 2012;302: E52-60.

17. Res PT, Groen B, Pennings B, Beelen M, Wallis GA, Gijsen AP, Senden JM, and LJ VANL. Protein ingestion before sleep improves postexercise overnight recovery. Med Sci Sports Exerc 2012;44:1560-9.

18. Glover EI, Phillips SM, Oates BR, Tang JE, Tarnopolsky MA, Selby A, Smith K, and Rennie MJ. Immobilization induces anabolic resistance in human myofibrillar protein synthesis with low and high dose amino acid infusion. J Physiol 2008;586:6049-61.

19. Wall BT, Snijders T, Senden JM, Ottenbros CL, Gijsen AP, Verdijk LB, and van Loon LJ. Disuse impairs the muscle protein synthetic response to protein ingestion in healthy men. J Clin Endocrinol Metab 2013;98:4872-81.

20. Wall BT, Dirks ML, Verdijk LB, Snijders T, Hansen D, Vranckx P, Burd NA, Dendale P, and van Loon L. Neuromuscular electrical stimulation increases muscle protein synthesis in elderly type 2 diabetic men. Am J Physiol Endocrinol Metab 2012;303:E614-23.

21. Dirks ML, Wall BT, Snijders T, Ottenbros CL, Verdijk LB, and van Loon $\amalg$. Neuromuscular electrical stimulation prevents muscle disuse atrophy during leg immobilization in humans. Acta Physiol (Oxf) 2014;210:628-41. 
22. Expert Committee on the D, and Classification of Diabetes M. Report of the expert committee on the diagnosis and classification of diabetes mellitus. Diabetes Care 2003;26 Suppl 1: 20.

23. Jones PR, and Pearson J. Anthropometric determination of leg fat and muscle plus bone volumes in young male and female adults. J Physiol 1969;204:63P-6P.

24. Bergstrom J. Percutaneous needle biopsy of skeletal muscle in physiological and clinical research. Scand J Clin Lab Invest 1975;35:609-16.

25. Wall BT, Hamer HM, de Lange A, Kiskini A, Groen BB, Senden JM, Gijsen AP, Verdijk LB, and van Loon LJ. Leucine co-ingestion improves post-prandial muscle protein accretion in elderly men. Clin Nutr 2013;32: 412-9.

26. van Loon LJ, Boirie Y, Gijsen AP, Fauquant J, de Roos AL, Kies AK, Lemosquet S, Saris WH, and Koopman R. The production of intrinsically labeled milk protein provides a functional tool for human nutrition research. J Dairy Sci 2009;92:4812-22.

27. Biolo G, Tessari P, Inchiostro S, Bruttomesso D, Fongher C, Sabadin L, Fratton M, Valerio A, and Tiengo A. Leucine and phenylalanine kinetics during mixed meal ingestion: a multiple tracer approach. Am J Physiol 1992;262:63.

28. Burd NA, Cermak NM, Kouw IW, Gorissen SH, Gijsen AP, and van Loon LJ. The use of doubly labeled milk protein to measure postprandial muscle protein synthesis rates in vivo in humans. J Appl Physiol 2014; 117:1363-70.

29. Deitrick JE. The effect of immobilization on metabolic and physiological functions of normal men. Bull $\mathrm{N}$ Y Acad Med 1948;24:364-75.

30. Haruna Y, Suzuki Y, Kawakubo K, Yanagibori R, and Gunji A. Decremental reset in basal metabolism during 20-days bed rest. Acta Physiol Scand Suppl 1994;616:43-9.

31. Ingemann-Hansen T, and Halkjaer-Kristensen J. Computerized tomographic determination of human thigh components. The effects of immobilization in plaster and subsequent physical training. Scand J Rehabil Med 1980;12:27-31.

32. LeBlanc AD, Schneider VS, Evans HJ, Pientok C, Rowe R, and Spector E. Regional changes in muscle mass following 17 weeks of bed rest. J Appl Physiol 1992;73:2172-8.

33. Wall BT, Snijders T, Senden JM, Ottenbros CL, Gijsen AP, Verdijk LB, and van Loon LJ. Disuse impairs the muscle protein synthetic response to protein ingestion in healthy men. J Clin Endocrinol Metab 2013;98: 4872-81.

34. Luiking YC, Engelen MP, Soeters PB, Boirie Y, and Deutz NE. Differential metabolic effects of casein and soy protein meals on skeletal muscle in healthy volunteers. Clin Nutr 2011;30:65-72.

35. Tipton KD, Elliott TA, Cree MG, Wolf SE, Sanford AP, and Wolfe RR. Ingestion of casein and whey proteins result in muscle anabolism after resistance exercise. Med Sci Sports Exerc 2004;36:2073-81.

36. Moore DR, Robinson MJ, Fry JL, Tang JE, Glover El, Wilkinson SB, Prior T, Tarnopolsky MA, and Phillips $\mathrm{SM}$. Ingested protein dose response of muscle and albumin protein synthesis after resistance exercise in young men. Am J Clin Nutr 2009;89:161-8.

37. Pennings B, Groen B, de Lange A, Gijsen AP, Zorenc AH, Senden JM, and van Loon L. Amino acid absorption and subsequent muscle protein accretion following graded intakes of whey protein in elderly men. Am J Physiol Endocrinol Metab 2012;302:E992-9.

38. Volpi E, Ferrando AA, Yeckel CW, Tipton KD, and Wolfe RR. Exogenous amino acids stimulate net muscle protein synthesis in the elderly. J Clin Invest 1998;101:2000-7.

39. Areta JL, Burke LM, Ross ML, Camera DM, West DW, Broad EM, Jeacocke NA, Moore DR, Stellingwerff T, Phillips SM, Hawley JA, and Coffey VG. Timing and distribution of protein ingestion during prolonged recovery from resistance exercise alters myofibrillar protein synthesis. J Physiol 2013;591:2319-31.

40. Wall BT, and van Loon LJ. Nutritional strategies to attenuate muscle disuse atrophy. Nutr Rev 2013;71: 195-208.

41. Walrand S, and Boirie Y. Optimizing protein intake in aging. Curr Opin Clin Nutr Metab Care 2005;8: 89-94.

42. Guillet C, Prod'homme M, Balage M, Gachon P, Giraudet C, Morin L, Grizard J, and Boirie Y. Impaired anabolic response of muscle protein synthesis is associated with S6K1 dysregulation in elderly humans. FASEB J 2004;18:1586-7.

43. Rasmussen BB, Fujita S, Wolfe RR, Mittendorfer B, Roy M, Rowe VL, and Volpi E. Insulin resistance of muscle protein metabolism in aging. FASEB J 2006;20:768-9. 
44. Wall BT, Dirks ML, Verdijk LB, Snijders T, Hansen D, Vranckx P, Burd NA, Dendale P, and van Loon LJ. Neuromuscular electrical stimulation increases muscle protein synthesis in elderly type 2 diabetic men. Am J Physiol Endocrinol Metab 2012;303:23.

45. Suetta C, Frandsen U, Mackey AL, Jensen L, Hvid LG, Bayer ML, Petersson SJ, Schroder HD, Andersen JL, Aagaard $P$, Schjerling $P$, and Kjaer $M$. Ageing is associated with diminished muscle re-growth and myogenic precursor cell ex pansion early after immobility-induced atrophy in human skeletal muscle. J Physiol 2013;591:3789-804.

46. Dirks ML, Hansen D, Van Assche A, Dendale P, and Van Loon L. Neuromuscular electrical stimulation prevents muscle wasting in critically ill comatose patients. Clin Sci 2015;128:357-65.

47. von Haehling S, Morley JE, Coats AJ, and Anker SD. Ethical guidelines for publishing in the Journal of Cachexia, Sarcopenia and Muscle: update 2015. J Cachexia Sarcopenia Muscle. 2015;6:315-6. 


\section{Chapter 7}

General discussion 
Chapter 7 


\section{General discussion}

From a physiological standpoint, skeletal muscle mass is maintained by the orchestrated up- and down regulation of skeletal muscle protein synthesis and breakdown. ${ }^{1}$ It has been well established that protein turnover in skeletal muscle tissue is highly responsive to nutrient intake and muscle contraction. Protein ingestion increases both muscle protein synthesis as well as muscle protein breakdown rates, albeit the latter to a lesser extent, resulting in a positive net muscle protein balance..$^{2-4}$ The postprandial muscle protein synthetic and anti-proteolytic response to feeding is regulated on various levels, ranging from protein digestion and amino acid absorption, ${ }^{5,6}$ the postprandial rise in circulating insulin, the subsequent increase in microvascular recruitment, ${ }^{7,8}$ amino acid uptake in skeletal muscle tissue, ${ }^{9}$ and myofibrillar muscle protein synthesis and breakdown. ${ }^{10}$ All of these aspects of postprandial protein handling may play a role in the reduced sensitivity of senescent muscle to the anabolic properties of amino acids, a phenomenon that is now referred to as the 'anabolic resistance of aging'. ${ }^{11}$

\section{Muscle tissue perfusion and anabolic resistance}

Although the exact underlying mechanisms of 'anabolic resistance' remain to be established, there is an emerging body of evidence suggesting that resistance of senescent muscle to the postprandial insulin-mediated stimulation of muscle perfusion may play a key role. ${ }^{7,12,13}$ Both anatomical and functional aspects of the microvascular circulation determine the capacity for postprandial perfusion of skeletal muscle tissue. From an anatomical point of view, both the number and diameter of arterioles and capillaries define the perfusion capacity of muscle tissue. Higher vascular density and a larger inner diameter of the blood vessel help to improve the delivery of amino acids to muscle tissue, ${ }^{13}$ thereby stimulating muscle protein synthesis. In addition, blood vessel diameter also affects the flow resistance. As the diameter gets smaller, the proportion of the blood making contact with the endothelial wall will increase. The greater amount of contact with the endothelial wall will increase the total resistance against the blood flow and lowers perfusion of the muscle. ${ }^{14}$ In chapter 4 of this dissertation, we assessed the microvascular (i.e. 3-35 $\mu \mathrm{m}$ vessel diameter) structure in young, older, and older type 2 diabetic patients. Smaller capillaries tended to be less prevalent in muscle collected from older and older type 2 diabetes patients when compared with muscle tissue samples taken from the healthy young controls. ${ }^{15}$ The observation of a lower capillary density in leg muscle tissue in the older and older type 2 diabetes patients compared with the young correlates well with the apparent loss of perfused small nutritive capillaries visualized with sidestream darkfield imaging. The capillary loss seems to occur without concomitant arteriolar/venular loss in the older and older 
type 2 diabetes patients when compared with the young control subjects. The exact cause of the lower microvascular density observed in the older populations is not known but may be instrumental in the development of anabolic resistance.

From a functional perspective, we defined perfusion as the capacity to transport nutrients and gasses over the vessel wall towards muscle tissue. In addition to the anatomical changes mentioned before, we $\mathrm{e}^{15}$ and others ${ }^{16-19}$ present data to indicate that the endothelial wall function may be compromised in disease and senescent tissue. In the search for novel targets to assess microvascular function, the recognition of the potential role of the endothelial glycocalyx layer ${ }^{20}$ in mediating vascular function offers new and exciting opportunities. The endothelial glycocalyx is a carbohydrate-rich layer lining the vascular endothelium. It seems to be connected to the endothelium through several "backbone" molecules, mainly proteoglycans and also glycoproteins. These structures form a network in which soluble molecules, either plasma- or endothelium-derived, are incorporated. ${ }^{21}$ Eskens and colleagues have demonstrated that the degeneration of endothelial glycocalyx results in elevated permeability of the endothelial layer, thereby compromising protective function and transport capacity over the endothelium. ${ }^{22}$ In chapter 4 , we show that the endothelial glycocalyx layer, expressed as the erythrocyte perfused boundary region (PBR), is larger in the older and older type 2 diabetic patients, compared with the healthy young subjects. The larger PBR reflects higher permeability for red blood cells into the luminal part of the endothelial wall. A thicker perfused boundary region, as we see in our older and older type 2 diabetic patients, ${ }^{15}$ is associated with endothelial dysfunction as observed in various organs in multiple patient groups. ${ }^{23-25}$ The greater PBR is accompanied by a reduced endothelial glycocalyx thickness, compromising nutrient exchange over the endothelium. We propose that a compromised nutrient exchange in the postprandial state in the older and older type 2 diabetic patients may contribute to the development of anabolic resistance to feeding and, as such, may be one of the underlying mechanisms responsible for the loss of muscle mass with aging

The observed differences in microvascular structure and/or function between healthy young, healthy older, and insulin resistant older populations, indicates that impairments in the postprandial delivery of amino acids to the muscle in the senescent and/or insulin resistant muscle may contribute to the development of anabolic resistance and the subsequent loss of muscle mass with aging. In support, recent work by our lab in collaboration with Nottingham has shown that lipid oversupply can directly induce anabolic resistance, further implying that there may be a direct functional relationship with endothelial function, insulin sensitivity and anabolic resistance. ${ }^{26,27}$ Of course, we cannot determine whether changes in microvascular structure or function are either a cause of a consequence of muscle loss with aging. Therefore, we followed up our work by further investigating the role of insulin in the postprandial stimulation of muscle perfusion and subsequent muscle protein synthesis rates in both young and older men. 


\section{Muscle tissue perfusion and the role of insulin}

Whereas several studies have pointed out the potential of elevated insulin levels to increase capillary blood volume in muscle, ${ }^{28-31}$ the impact of the postprandial rise in circulating insulin on muscle protein synthesis rate is still a topic of intense debate. Many of the parameters that define postprandial protein handling, such as amino acid uptake in skeletal muscle tissue, intramuscular anabolic signaling, and myofibrillar muscle protein synthesis and breakdown, are modulated by the postprandial rise in circulating insulin. Insulin stimulates muscle protein synthesis directly by activating the translational machinery. ${ }^{32,33}$ Furthermore, insulin can modulate postprandial precursor availability by stimulating nutritive blood flow to skeletal muscle tissue ${ }^{34}$ and, as such, enhance amino acid uptake. ${ }^{7,35}$ Though ample studies have been performed to assess the impact of exogenous insulin administration on muscle protein synthesis, data do not elucidate the role of (exogenous) insulin on muscle protein synthesis rates in vivo in humans. ${ }^{36-38}$ In chapter $\mathbf{3}$ we assessed to what extent a physiological increase in postprandial insulin availability stimulates amino acid uptake in skeletal muscle tissue. ${ }^{39} \mathrm{We}$ observed greater amino acid uptake over the leg following ingestion of a single bolus of protein when postprandial insulin levels were further increased by exogenous insulin administration. Despite the increase in amino acid uptake in the leg, postprandial muscle protein synthesis rates and deposition of protein derived amino acids into de novo muscle protein were not further improved. These findings indicate that amino acid availability and, therefore, muscle tissue perfusion do not limit the postprandial increase in muscle protein synthesis rate. This implies that intracellular mechanisms are controlling the postprandial muscle protein synthetic response to protein. This seems to agree with the observation that muscle contraction can augment local muscle protein synthesis and augment the postprandial muscle protein synthetic response to feeding. ${ }^{40}$

\section{Physical activity}

Increasing physical activity has been identified as an effective strategy to increase the sensitivity of skeletal muscle tissue to the anabolic properties of amino acids. When exercise is performed prior to food intake, we see that the postprandial rise in muscle protein synthesis rate is not only increased, but also sustained over a more prolonged period of time. ${ }^{6}$ Unfortunately, in many clinical conditions it is impossible to simply increase physical activity levels. Many clinical conditions are characterized by a decline in physical activity. Bed rest or immobilization due to injury, disease or surgery has been shown to result in a rapid decline in muscle mass and strength. ${ }^{41}$ In older adults, physical inactivity during hospitalization is almost an accepted part of the inpatient experience, yet it clearly contributes to a host of negative clinical outcomes, including a 
greater incidence of co-morbidities, reduced ability to perform activities of daily living, increased incidence of re-admission and greater needs for institutionalization. ${ }^{41,42}$ The rapid loss of muscle mass during periods of inactivity is attributed to a decline in both basal, post-absorptive muscle protein synthesis rates, as well as a blunted muscle protein synthetic response to amino acid administration. ${ }^{43}$ Furthermore, we recently showed that merely a few days of limb immobilization already results in substantial muscle loss with a large decline in the muscle protein synthetic response to the ingestion of a single meal-like bolus of protein. ${ }^{44}$ Obviously, it is of important clinical relevance to develop effective strategies that can overcome this anabolic resistance and, as such, preserve muscle mass during short periods of muscle disuse. ${ }^{45}$

Surrogates to mimic muscle contractions could be sought to improve the sensitivity of skeletal muscle tissue to the anabolic properties of feeding. Neuromuscular electrical stimulation (NMES) offers such an attractive alternative strategy to induce (local) muscle contractions, thereby possibly acting as a surrogate for the loss of physical activity during periods of muscle disuse. ${ }^{46-48}$ NMES has been shown to locally increase muscle protein synthesis in a basal post-absorptive state. ${ }^{49}$ NMES can be applied several times a day, at different locations, specific for an individual muscle group or on a whole body level, depending on the level of disuse. Prolonged application of NMES has been reported to attenuate the loss of muscle mass and strength in patients recovering from surgery, ${ }^{50-52}$ suffering from severe cardiovascular complications, ${ }^{53,54}$ or treated in the intensive care unit. ${ }^{55-57}$ Besides conditions of severe illness, I believe that healthy community-dwelling older adults could also benefit from NMES to support muscle maintenance during short periods of (relative) disuse, such as sickness at home, post-hospitalization periods and various disorders that hinder independent mobilization (i.e. peripheral neuropathy, edema, arthrosis, ulcera, etc.). Therefore, we applied NMES in chapter 6 and clearly demonstrated that the overnight muscle protein synthetic response to pre-sleep protein ingestion can be further increased by the application of a NMES session performed earlier that evening. NMES seems to represent a practical and efficient strategy not only to preserve muscle mass during short term hospital stay in older adults, but may also proof effective in various situations where maintenance of muscle mass is needed. Potential sites for application of NMES are during hospitalization, post-surgery rehabilitation, recovery from sports injury, convalescence from illness, microgravity or any other situation leading to insufficient physical activity and consequent muscle loss. ${ }^{49}$

\section{Exercise mimetics and overnight feeding}

Because physical activity and exercise mimetics augment the sensitivity of skeletal muscle tissue to the anabolic properties of amino acids, ${ }^{51}$ we combined NMES with presleep protein ingestion in the study described in chapter 6 . Overnight muscle protein 
synthesis rates have been shown to be quite low compared with daytime protein synthesis rates. ${ }^{58}$ We questioned whether limited plasma amino acid availability during the night prevents overnight muscle protein synthesis rates to be elevated above basal, post-absorptive levels. Consequently, we first assessed whether intra-gastric protein provision during sleep would be followed by proper dietary protein digestion and absorption kinetics, resulting in a substantial increase in plasma amino acid availability and, as such, stimulate overnight muscle protein synthesis rates. In line with our hypothesis, we showed in chapter 5 that protein administration during overnight sleep is followed by proper dietary protein digestion and absorption kinetics, thereby increasing plasma amino acid availability throughout the night, and increasing overnight muscle protein synthesis rates. ${ }^{59}$ Therefore, overnight dietary protein administration allows us to expand the window of opportunity during which we can modulate muscle protein metabolism. Our results displayed in chapter 6 show that presleep protein ingestion can increase overnight muscle protein synthesis rates and that the application of NMES augments the efficacy of pre-sleep protein provision to augment overnight muscle protein synthesis rates. This provides us with an interesting combination of interventional strategies that could prevent or attenuate the loss of muscle mass in the older population in both health and disease. Follow-up research should address the clinical relevance and practical applicability of these interventional strategies in various older subpopulations. This will also require further technological development to expand the use of NMES to various muscle groups and limbs, to allow a more whole-body relevant approach. Moreover, various nutritional strategies should be developed to individualize the pre-sleep protein or amino acid administration to the patients' needs.

\section{Directions of future research}

The performed experiments have increased our knowledge on the regulation of postprandial protein metabolism, the role of micro vascular perfusion, and neuromuscular stimulation of muscle tissue in postprandial muscle protein synthesis. Nonetheless, there are many questions that remain to be answered. Therefore, future research is required to combine all data and define more practical dietary recommendations to stimulate muscle mass preservation during aging in both health and disease. 


\section{Questions that should be addressed in future research include}

- Does the endothelial glycocalyx have a regulatory role in the postprandial muscle protein synthetic response to feeding?

- How important are systemic insulin levels and peripheral insulin sensitivity for the permeability of the endothelial glycocalyx and the subsequent impact on postprandial muscle protein synthesis?

- What are the parameters of NMES that stimulate muscle protein synthesis and what protocols are most effective to prevent or attenuate muscle loss during limb immobilization or bed rest?

- What is the impact of late night or pre-sleep protein feeding with or without NMES on muscle mass preservation during recovery from orthopedic surgery?

- Can we prevent or attenuate the loss of muscle mass in patients with cancer cachexia by nutritional interventions with or without the use of exercise (mimetics)?

- How can we implement effective nutritional and exercise strategies, such as presleep protein feeding and NMES, in a primary healthcare setting?

- Does protein supplementation prior to and during short term disuse prevent or attenuate the loss of muscle mass, decline in mobility and reduction in the quality of life in the older population?

- What is the clinical relevance of pre-sleep protein feeding as an interventional strategy to prevent or treat muscle loss in the older population in both health and disease?

- Are there improvements in clinical outcome parameters following the application of NMES in hospitalized patients that are limited in their physical activity?

- What is the impact of atherosclerosis on (local) muscle protein synthesis in a postabsorptive or a postprandial setting? 


\section{References}

1. Wall BT, Gorissen SH, Pennings B, Koopman R, Groen BB, Verdijk LB, et al. Aging Is Accompanied by a Blunted Muscle Protein Synthetic Response to Protein Ingestion. PLoS One. 2015;10:e0140903.

2. Volpi E, Sheffield-Moore M, Rasmussen BB, Wolfe RR. Basal muscle amino acid kinetics and protein synthesis in healthy young and older men. JAMA. 2001;286:1206-12.

3. Baños G, Daniel P, Moorhouse S, Pratt O. The movement of amino acids between blood and skeletal muscle in the rat. The Journal of physiology. 1973;235:459-75.

4. Silk DB, Grimble GK, Rees RG. Protein digestion and amino acid and peptide absorption. Proc Nutr Soc. 1985;44:63-72.

5. Rodriguez P, Setten M, Maskin L, Bonelli I, Vidomlansky S, Attie S, et al. Muscle weakness in septic patients requiring mechanical ventilation: protective effect of transcutaneous neuromuscular electrical stimulation. J Crit Care. 2012;27:3190-8.

6. Pennings B, Koopman R, Beelen M, Senden JM, Saris WH, van Loon LJ. Exercising before protein intake allows for greater use of dietary protein-derived amino acids for de novo muscle protein synthesis in both young and elderly men. Am J Clin Nutr. 2011;93:322-31.

7. Rasmussen BB, Fujita S, Wolfe RR, Mittendorfer B, Roy M, Rowe VL, et al. Insulin resistance of muscle protein metabolism in aging. FASEB J. 2006;20:768-9.

8. Zhang $\mathrm{H}$, Dellsperger $\mathrm{K}$, Zhang $\mathrm{C}$. The link between metabolic abnormalities and endothelial dysfunction in type 2 diabetes: an update. Basic Res Cardiol. 2012;107:237.

9. English K, Paddon-Jones D. Protecting muscle mass and function in older adults during bed rest. Curr Opin Clin Nutr Metab Care. 2010;13:34-9.

10. Volpi E, Ferrando A, Yeckel C, Tipton K, Wolfe R. Exogenous amino acids stimulate net muscle protein synthesis in the elderly. J Clin Invest. 1998;101:2000-7.

11. Wall BT, Cermak NM, van Loon LJ. Dietary protein considerations to support active aging. Sports Med. 2014;44 Suppl 2:S185-94.

12. Timmerman KL, Lee JL, Dreyer HC, Dhanani S, Glynn EL, Fry CS, et al. Insulin stimulates human skeletal muscle protein synthesis via an indirect mechanism involving endothelial-dependent vasodilation and mammalian target of rapamycin complex 1 signaling. J Clin Endocrinol Metab. 2010;95:3848-57.

13. Timmerman KL, Lee JL, Fujita S, Dhanani S, Dreyer HC, Fry CS, et al. Pharmacological vasodilation improves insulin-stimulated muscle protein anabolism but not glucose utilization in older adults. Diabetes. 2010;59:2764-71.

14. Hall JE. Guyton and Hall textbook of medical physiology. 13th edition. ed. Philadelphia, PA: Elsevier; 2016. xix, 1145 pages $p$.

15. Groen BB, Hamer HM, Snijders T, van Kranenburg J, Frijns D, Vink H, et al. Skeletal muscle capillary density and microvascular function are compromised with aging and type 2 diabetes. J Appl Physiol (1985). 2014;116:998-1005.

16. Barrett E, Liu Z. The endothelial cell: an "early responder" in the development of insulin resistance. Rev Endocr Metab Disord. 2013;14:21-7.

17. Muniyappa R, lantorno $M$, Quon $M$. An integrated view of insulin resistance and endothelial dysfunction. Endocrinol Metab Clin North Am. 2008;37:685.

18. Rodriguez-Manas L, El-Assar M, Vallejo S, Lopez-Doriga P, Solis J, Petidier R, et al. Endothelial dysfunction in aged humans is related with oxidative stress and vascular inflammation. Aging Cell. 2009;8:226-38.

19. Zhang H, Dellsperger KC, Zhang C. The link between metabolic abnormalities and endothelial dysfunction in type 2 diabetes: an update. Basic Res Cardiol. 2012;107:1-11.

20. Weinbaum S, Tarbell JM, Damiano ER. The structure and function of the endothelial glycocalyx layer. Annu Rev Biomed Eng. 2007;9:121-67.

21. Reitsma S, Slaaf DW, Vink H, van Zandvoort MA, oude Egbrink MG. The endothelial glycocalyx: composition, functions, and visualization. Pflugers Arch. 2007;454:345-59.

22. Eskens BJ, Mooij HL, Cleutjens JP, Roos JM, Cobelens JE, Vink H, et al. Rapid insulin-mediated increase in microvascular glycocalyx accessibility in skeletal muscle may contribute to insulin-mediated glucose disposal in rats. PLoS One. 2013;8:e55399. 
23. Broekhuizen LN, Mooij HL, Kastelein JJ, Stroes ES, Vink H, Nieuwdorp M. Endothelial glycocalyx as potential diagnostic and therapeutic target in cardiovascular disease. Curr Opin Lipidol. 2009;20:57-62.

24. Martens RJH, Vink H, van Oostenbrugge RJ, Staals J. Sublingual microvascular glycocalyx dimensions in lacunar stroke patients. Cerebrovasc Dis. 2013;35:451-4.

25. Vlahu CA, Lemkes BA, Struijk DG, Koopman MG, Krediet RT, Vink H. Damage of the endothelial glycocalyx in dialysis patients. J Am Soc Nephrol. 2012;23:1900-8.

26. Stephens FB, Chee C, Wall BT, Murton AJ, Shannon CE, van Loon LJ, et al. Lipid-induced insulin resistance is associated with an impaired skeletal muscle protein synthetic response to amino acid ingestion in healthy young men. Diabetes. 2015;64:1615-20.

27. Wall BT, Dirks ML, Snijders T, Stephens FB, Senden JM, Verscheijden ML, et al. Short-term muscle disuse atrophy is not associated with increased intramuscular lipid deposition or a decline in the maximal activity of key mitochondrial enzymes in young and older males. Exp Gerontol. 2015;61:76-83.

28. Barrett EJ, Wang H, Upchurch CT, Liu Z. Insulin regulates its own delivery to skeletal muscle by feedforward actions on the vasculature. Am J Physiol Endocrinol Metab. 2011;301:E252-63.

29. Eggleston E, Jahn L, Barrett E. Hyperinsulinemia rapidly increases human muscle microvascular perfusion but fails to increase muscle insulin clearance: evidence that a saturable process mediates muscle insulin uptake. Diabetes. 2007;56:2958-63.

30. Vincent MA, Clerk LH, Lindner JR, Klibanov AL, Clark MG, Rattigan S, et al. Microvascular recruitment is an early insulin effect that regulates skeletal muscle glucose uptake in vivo. Diabetes. 2004;53:1418-23.

31. Zhang L, Vincent MA, Richards SM, Clerk LH, Rattigan S, Clark MG, et al. Insulin sensitivity of muscle capillary recruitment in vivo. Diabetes. 2004;53:447-53.

32. Jefferson LS, Rannels DE, Munger BL, Morgan HE. Insulin in the regulation of protein turnover in heart and skeletal muscle. Fed Proc. 1974;33:1098-104.

33. Proud CG, Denton RM. Molecular mechanisms for the control of translation by insulin. Biochem J. 1997;328:329-41.

34. Muniyappa R, Montagnani M, Koh KK, Quon MJ. Cardiovascular Actions of Insulin. Endocrine Rev. 2007;28:463-91.

35. Timmerman K, Lee J, Fujita S, Dhanani S, Dreyer H, Fry C, et al. Pharmacological vasodilation improves insulin-stimulated muscle protein anabolism but not glucose utilization in older adults. Diabetes. 2010;59:2764-71.

36. Phillips SM. Insulin and muscle protein turnover in humans: stimulatory, permissive, inhibitory, or all of the above? Am J Physiol Endocrinol Metab. 2008;295:E731.

37. Trommelen J, Groen B, Hamer H, de Groot LC, van Loon LJ. MECHANISMS IN ENDOCRINOLOGY: Exogenous insulin does not increase muscle protein synthesis rate when administrated systemically: a systematic review. Eur J Endocrinol. 2015;173:R25-34..

38. Trommelen J, Groen BB, Hamer HM, de Groot LC, van Loon L. MECHANISMS IN ENDOCRINOLOGY: Exogenous insulin does not increase muscle protein synthesis rate when administered systemically: a systematic review. Eur J Endocrinol. 2015;173:R25-34.

39. Groen BB, Horstman AM, Hamer HM, de Haan M, van Kranenburg J, Bierau J, et al. Postprandial protein handling: You are what you just ate. PLoS One. 2015;10:e0141582.

40. Witard OC, Tieland M, Beelen M, Tipton KD, van Loon LJ, Koopman R. Resistance exercise increases postprandial muscle protein synthesis in humans. Med Sci Sports Exerc. 2009;41:144-54.

41. English KL, Paddon-Jones D. Protecting muscle mass and function in older adults during bed rest. Curr Opin Clin Nutr Metab Care. 2010;13:34-9.

42. Covinsky KE, Palmer RM, Fortinsky RH, Counsell SR, Stewart AL, Kresevic D, et al. Loss of independence in activities of daily living in older adults hospitalized with medical illnesses: increased vulnerability with age. J Am Geriatr Soc. 2003;51:451-8.

43. Glover El, Phillips SM, Oates BR, Tang JE, Tarnopolsky MA, Selby A, et al. Immobilization induces anabolic resistance in human myofibrillar protein synthesis with low and high dose amino acid infusion. J Physiol. 2008;586:6049-61.

44. Wall BT, Snijders T, Senden JM, Ottenbros CL, Gijsen AP, Verdijk LB, et al. Disuse impairs the muscle protein synthetic response to protein ingestion in healthy men. J Clin Endocrinol Metab. 2013;98: 4872-81. 
45. Wall BT, Dirks ML, Snijders T, van Dijk JW, Fritisch M, Verdijk LB, et al. Short-term muscle disuse lowers myofibrillar protein synthesis rates and induces anabolic resistance to protein ingestion. Am J Physiol Endocrinol Metab. 2016;310:E137-47.

46. Eriksson E, Häggmark T. Comparison of isometric muscle training and electrical stimulation supplementing isometric muscle training in the recovery after major knee ligament surgery. A preliminary report. Am J Sports Med. 1979;7:169-71.

47. Gibson J, Morrison W, Scrimgeour C, Smith K, Stoward P, Rennie M. Effects of therapeutic percutaneous electrical stimulation of atrophic human quadriceps on muscle composition, protein synthesis and contractile properties. Eur J Clin Invest. 1989;19:206-12.

48. Williams JG, Street M. Sequential faradism in quadriceps rehabilitation. Physiotherapy. 1976;62:252-4.

49. Wall BT, Dirks ML, Verdijk LB, Snijders T, Hansen D, Vranckx P, et al. Neuromuscular electrical stimulation increases muscle protein synthesis in elderly type 2 diabetic men. Am J Physiol Endocrinol Metab. 2012;303:E614-23.

50. Snyder-Mackler L, Delitto A, Stralka SW, Bailey SL. Use of electrical stimulation to enhance recovery of quadriceps femoris muscle force production in patients following anterior cruciate ligament reconstruction. Phys Ther. 1994;74:901-7.

51. Vinge O, Edvardsen L, Jensen F, Jensen F, Wernerman J, Kehlet H. Effect of transcutaneous electrical muscle stimulation on postoperative muscle mass and protein synthesis. Br J Surg. 1996;83:360-3.

52. Wigerstad-Lossing I, Grimby G, Jonsson T, Morelli B, Peterson L, Renström P. Effects of electrical muscle stimulation combined with voluntary contractions after knee ligament surgery. Med Sci Sports Exerc. 1988;20:93-8.

53. Banerjee P, Caulfield B, Crowe L, Clark A. Prolonged electrical muscle stimulation exercise improves strength, peak VO2, and exercise capacity in patients with stable chronic heart failure. J Card Fail. 2009;15:319-26.

54. Sillen M, Speksnijder C, Eterman R-MA, Janssen P, Wagers S, Wouters E, et al. Effects of neuromuscular electrical stimulation of muscles of ambulation in patients with chronic heart failure or COPD: a systematic review of the English-language literature. Chest. 2009;136:44-61.

55. Gerovasili V, Stefanidis K, Vitzilaios K, Karatzanos E, Politis P, Koroneos A, et al. Electrical muscle stimulation preserves the muscle mass of critically ill patients: a randomized study. Crit Care. 2009;13:R161.

56. Gruther W, Kainberger F, Fialka-Moser V, Paternostro-Sluga T, Quittan M, Spiss C, et al. Effects of neuromuscular electrical stimulation on muscle layer thickness of knee extensor muscles in intensive care unit patients: a pilot study. J Rehabil Med. 2010;42:593-7.

57. Dirks ML, Hansen D, Van Assche A, Dendale P, Van Loon L. Neuromuscular electrical stimulation prevents muscle wasting in critically ill comatose patients. Clin Sci (Lond). 2015;128:357-65.

58. Beelen M, Tieland M, Gijsen AP, Vandereyt H, Kies AK, Kuipers H, et al. Coingestion of carbohydrate and protein hydrolysate stimulates muscle protein synthesis during exercise in young men, with no further increase during subsequent overnight recovery. J Nutr. 2008;138:2198-204.

59. Groen BB, Res PT, Pennings B, Hertle E, Senden JM, Saris WH, et al. Intragastric protein administration stimulates overnight muscle protein synthesis in elderly men. Am J Physiol Endocrinol Metab. 2012; 302:E52-60. 
Summary 


\section{Summary}

Aging is accompanied by a progressive decline in skeletal muscle mass and strength, known as sarcopenia, leading to the loss of functional capacity and an increased risk of developing chronic metabolic disease. Sarcopenia increases hospital and/or nursing home admissions and may reduce the quality of life of older individuals. It has been well established that protein turnover in skeletal muscle tissue is highly responsive to nutrient intake and muscle contraction. Protein ingestion stimulates muscle protein synthesis and inhibits muscle protein breakdown resulting in net muscle protein accretion. Disturbances in skeletal muscle protein turnover result in a structural imbalance between protein synthesis and breakdown, leading to sarcopenia. The postprandial muscle protein synthetic and anti-proteolytic response to feeding is regulated on various levels, ranging from protein digestion and amino acid absorption, the postprandial rise in circulating insulin, the subsequent increase in microvascular recruitment, amino acid uptake in skeletal muscle tissue, and myofibrillar muscle protein synthesis and breakdown. All of these aspects of postprandial protein handling may play a role in the reduced sensitivity of senescent muscle to the anabolic properties of amino acids, a phenomenon that is now referred to as the 'anabolic resistance of aging'.

In chapter 2, we apply a combination of methods to assess in vivo dietary protein digestion and subsequent amino acid absorption, the appearance of dietary protein derived amino acids in the circulation, the uptake and release of amino acids over the leg, the postprandial stimulation of muscle protein synthesis as well as the use of protein derived amino acids for de novo muscle protein synthesis within one single experiment. Ingestion of a single meal-like amount of protein allows $\sim 55 \%$ of the protein derived amino acids to become available in the circulation, thereby improving whole-body as well as leg muscle protein balance. Approximately $20 \%$ of the protein derived plasma amino acids are taken up in skeletal muscle tissue during a $5 \mathrm{~h}$ postprandial period, thereby stimulating muscle protein synthesis rates and providing precursors for de novo muscle protein. Chapter 2 quantifies postprandial protein handling and the subsequent use of dietary protein derived amino acids for de novo muscle protein synthesis in vivo in humans and provides a complete and comprehensive insight in the fact that you actually are what you just ate.

Many of the parameters that define postprandial protein handling are modulated by the postprandial rise in circulating insulin. Insulin stimulates muscle protein synthesis directly by activating the translational machinery. Furthermore, insulin may modulate postprandial precursor availability by stimulating nutritive blood flow to skeletal muscle tissue and enhancing amino acid uptake. However, the proposed role of insulin in stimulating postprandial muscle protein synthesis has been subject of intense debate. It remains unclear whether circulating insulin levels are merely permissive or rather modulatory in facilitating the postprandial increase in muscle protein synthesis. In 
chapter 3 we assess to what extent a physiological increase in postprandial insulin availability stimulates postprandial amino acid uptake, increases muscle protein synthesis, and augments the use of protein derived amino acids for de novo muscle protein synthesis in young and older males. This chapter provides a multi-level assessment of the impact of insulin availability on postprandial protein handling following ingestion of a single meal-like amount of protein in young and older males. We conclude that greater postprandial plasma insulin availability stimulates amino acid uptake over the leg but does not further augment the postprandial muscle protein synthetic response to protein feeding in healthy young and older males. Therefore, the postprandial rise in circulating insulin should be regarded as permissive rather than modulatory in driving the postprandial increase in muscle protein synthesis rates in both healthy young and older men.

Adequate muscle perfusion is essential for muscle mass maintenance, as it determines the rapid postprandial delivery of amino acids, nutrients and growth factors to the muscle, thereby stimulating muscle protein synthesis. An impaired responsiveness of the skeletal muscle microvasculature to postprandial insulin release may be attributed to impairments in muscle microvascular structure and endothelial function, which may include a decline in capillary density and structural changes of the endothelial wall. In chapter 4 we selected both young, older, as well as older, type 2 diabetic patients to compare muscle fiber type specific capillary density and endothelial function between healthy young, older men and age-matched type 2 diabetes patients. We conclude that aging and type 2 diabetes are accompanied with a reduced muscle mass, lower insulin sensitivity, reduced skeletal muscle capillary density, and compromised endothelial wall function. These observations indicate that both quantitative and qualitative changes in the microvasculature may contribute to the loss of skeletal muscle mass and the development of insulin resistance at a more advanced age and with type 2 diabetes.

In Chapter 5 and 6 we shift our focus towards a more practical approach. Two proof of principle studies extend on our previous findings and aim to optimize the postprandial response in older people. In chapter $\mathbf{5}$, we assess the impact of protein administration during sleep on in vivo protein digestion and absorption kinetics and subsequent muscle protein synthesis rates in older men. We conclude that protein administration during overnight sleep is followed by proper dietary protein digestion and absorption kinetics, thereby increasing plasma amino acid availability throughout the night. An increase in overnight plasma amino acid availability stimulates muscle protein synthesis during sleep and improves overnight whole-body protein balance in older males. Nocturnal dietary protein administration may represent an effective nutritional intervention strategy to support muscle mass maintenance in both health and disease.

In chapter 6 we introduce neuromuscular electrical stimulation (NMES) as an exercise mimetic to allow muscle contractions to occur. NMES can be used to attenuate disuse related anabolic resistance in older and clinically compromised populations. We performed unilateral NMES in the evening after a day of bed rest in 20 healthy older 
males to test whether the combination of NMES with dietary protein feeding prior to sleep could further stimulate overnight muscle protein accretion. It is concluded that the application of NMES in the evening further augments postprandial muscle protein accretion following protein ingestion prior to sleep. The application of NMES combined with protein ingestion prior to sleep represents a feasible strategy to optimize overnight muscle protein accretion, and may be of great clinical benefit to attenuate muscle loss in (more) clinically compromised individuals.

The final chapter elaborates on the primary findings described in this dissertation and identifies a number of topics that need to be addressed in the future. This dissertation shows that a combination of various factors modulate the postprandial muscle protein synthetic response to protein ingestion. Optimizing the metabolic fate of ingested protein to maximize postprandial muscle protein synthesis rates may contribute to the preservation of skeletal muscle mass with aging or in various clinical settings in more compromised patient populations. 
Samenvatting 


\section{Samenvatting}

Veroudering gaat gepaard met progressief verlies van spiermassa en spierkracht, ook wel bekend als sarcopenie. Sarcopenie leidt tot verlies van functionele capaciteit en is gerelateerd aan een hoger risico op het ontwikkelen van chronisch metabole ziekten. Ook gaat sarcopenie gepaard met verminderde mobiliteit en zelfredzaamheid, wat leidt tot een grotere kans op hospitalisatie of opname in een zorginstelling. Tenslotte gaat sarcopenie vaak gepaard met een afname in kwaliteit van leven.

Fysieke activiteit en gezonde (met name eiwitrijke) voeding blijken beide op effectieve wijze spieropbouw (synthese) te stimuleren en dragen daarmee bij aan behoud van spiermassa en functionele capaciteit bij ouderen. De verhoogde spiereiwitsynthese na inname van eiwitten in de voeding wordt gereguleerd door verschillende processen. Meest relevant voor dit proefschrift zijn de vertering van eiwitten, opname van aminozuren in de darm, het beschikbaar komen van aminozuren in de bloedsomloop, het transport van aminozuren naar skeletspierweefsel, de opname van aminozuren door spiercellen, en uiteindelijk de intracellulaire signalering die spiereiwitsynthese activeert. Op een hogere leeftijd lijken de spieren minder gevoelig voor de anabole werking van eiwit inname. Dit noemen we anabole resistentie. Anabole resistentie speelt een belangrijke rol bij het verlies van spiermassa bij ouderen en patiënten, maar het exacte mechanisme dat hieraan ten grondslag ligt is nog niet duidelijk.

In hoofdstuk 2 wordt een aantal methoden gecombineerd om de anabole response na inname van 20 gram eiwit op kwantitatieve wijze in beeld te brengen. We bestuderen de eiwitvertering, de aminozuurabsorptie, het transport van de aminozuren in de bloedbaan, de opname en afgifte van aminozuren over het been en tenslotte de directe stimulatie van spiereiwitsynthese door de oraal ingenomen eiwitten. We concluderen dat $55 \%$ van de aminozuren die als eiwit geconsumeerd wordt, beschikbaar komt in de bloedbaan. Deze verhoogde beschikbaarheid van aminozuren stimuleert de spiereiwitsynthese, waarbij ongeveer $20 \%$ van de aminozuren afkomstig van de geconsumeerde eiwitten in spiereiwit wordt ingebouwd gedurende de eerste 5 uur na eiwitconsumptie. Hoofdstuk 2 schetst daarmee een kwantitatief beeld van wat er met geconsumeerde eiwitten in het menselijk lichaam gebeurt. In het bijzonder geeft het de relatie weer tussen oraal ingenomen eiwitten en de daaropvolgende stimulatie van de spiereiwitsynthese. Dit hoofdstuk vormt een wetenschappelijk fundament voor de bekende uitdrukking: je bent wat je eet.

De metabole weg die oraal ingenomen eiwitten afleggen alvorens tot stimulatie van eiwitsynthese te kunnen leiden, wordt op verschillende manieren beïnvloed door het hormoon insuline. Insuline stimuleert onder andere de aanmaak van spiereiwitten door op moleculair niveau de translatie en transscriptie voor de vorming van spiereiwitten te stimuleren. Daarnaast speelt insuline ook een belangrijke rol bij het verhogen van de doorbloeding in organen en spierweefsel. De toename in de doorbloeding verbetert mogelijk de opname van aminozuren en daarmee de aminozuur beschikbaarheid in 
spierweefsel. De rol van insuline in dit laatstgenoemde proces staat echter al lange tijd ter discussie. Onbekend is of insuline alleen een ondersteunende functie in dit proces heeft, of dat het ook een direct stimulerende werking heeft op de spiereiwitsynthese. Daarom bestuderen we in hoofdstuk 3 de rol van insuline met betrekking tot de opname van aminozuren in de bloedbaan en spierweefsel, stimulatie van de spiereiwitsynthese, en de mate waarin het geconsumeerde eiwit bijdraagt aan de vorming van nieuw spierweefsel bij gezonde jonge en oudere mannen. We concluderen dat verhoogde insulineconcentraties weliswaar resulteren in een verhoogde opname van aminozuren vanuit de darm in de bloedbaan en de spieren, maar dat deze verhoogde opname uiteindelijk niet leidt tot een verdere stimulatie van de spiereiwitsynthese bij gezonde jongeren en ouderen. De rol van insuline gedurende de postprandiale fase is dus ondersteunend van aard en heeft geen direct stimulerende werking op de aanmaak van nieuwe spiereiwitten.

Een adequate doorbloeding is belangrijk voor het behoud van spierweefsel. De mate van doorbloeding bepaalt hoeveel aminozuren, voedingsstoffen en groeifactoren tijdens de postprandiale fase de spier bereiken. De aanwezigheid van deze stoffen is noodzakelijk om groei en behoud van spierweefsel mogelijk te maken. Afname of beperkingen in de microvasculaire spierdoorbloeding gedurende de postprandiale fase kunnen een oorzaak zijn van spiermassaverlies tijdens veroudering en/of ziekte. Afname of beperkingen in de doorbloeding kunnen voortkomen uit structurele en functionele veranderingen in de microvascularisatie. Een afname van de capillaire dichtheid in spierweefsel rekent men tot structurele veranderingen. Veranderingen in de samenstelling van de binnenste bekleding van de vaatwand (de endotheellaag) mogen beschouwd worden als een functionele verandering. In hoofdstuk 4 vergelijken we daarom de capillaire dichtheid van het spierweefsel en het functioneren van de glycocalyx als onderdeel van de endotheellaag in gezonde jongeren, gezonde ouderen en ouderen gediagnosticeerd met type 2 diabetes mellitus (ouderdomssuikerziekte). We concluderen dat zowel veroudering als type 2 diabetes mellitus gepaard gaan met een afname van de capillaire dichtheid en een afname in de dichtheid van de glycocalyx. Deze observaties vormen een sterke indicatie dat zowel op structureel als op functioneel niveau belangrijke veranderingen in de microvascularisatie plaatsvinden bij ouderen en insuline-resistente patiënten, en dat deze veranderingen kunnen bijdragen aan verlies van spiermassa.

In hoofdstuk 5 en 6 verleggen we de focus naar praktijkgericht interventieonderzoek. De resultaten zoals gepresenteerd in de hoofdstukken $2 \mathrm{t} / \mathrm{m} 4$ dienen als uitgangspunt om de postprandiale spiereiwitsynthese respons bij ouderen te optimaliseren. In hoofdstuk 5 bestuderen we nachtelijke spiereiwitsynthese bij gezonde ouderen die tijdens slaap een bolus eiwit krijgen toegediend. Het toedienen van 40 gram eiwit tijdens de slaap wordt gevolgd door een effectieve eiwitvertering en aminozuurabsorptie. Dit resulteert in een verhoogde beschikbaarheid van aminozuren in het bloed die daarmee als bouwstenen voor de nieuw te vormen spiereiwitten kunnen 
fungeren. De beschikbare aminozuren verhogen de nachtelijke eiwitsynthese, alsmede de netto eiwitbalans gedurende de nacht. Hiermee wordt aangetoond dat nachtelijke toediening van eiwitten via de voeding een efficiënte interventiestrategie kan vormen om het verlies van spiermassa bij veroudering en/of ziekte tegen te gaan.

In hoofdstuk 6 introduceren we neuromusculaire elektrostimulatie (NMES) om op kunstmatige wijze spiercontracties te bewerkstelligen. Bewezen is dat NMES een effectieve methode is om anabole resistentie te voorkomen bij kwetsbare patiënten die gedurende korte of langere tijd geïmmobiliseerd zijn en geen fysieke activiteit kunnen uitvoeren. In het experiment zoals beschreven in hoofdstuk 6 wordt NMES toegepast op één been bij gezonde oudere mannen nadat zij een dag inactief op bed hebben gelegen. Voor de nacht consumeerden zij een identieke hoeveelheid eiwit zoals beschreven in hoofdstuk 5. Bestudeerd wordt of het toepassen van NMES de postprandiale eiwitrespons gedurende de nacht verder kan verhogen in vergelijking met het niet-gestimuleerde been. Geconcludeerd wordt dat NMES inderdaad de nachtelijke opbouw van nieuwe spiereiwitten verhoogt wanneer deze vergeleken wordt met het niet-gestimuleerde been na inname van 40 gram caseïne eiwit. Hieruit blijkt dat de combinatie van de inname van eiwitrijke voeding voor of tijdens het slapen (hoofdstuk 5) met neuromusculaire elektrostimulatie een effectieve strategie zou kunnen zijn om spiermassaverlies bij ouderen en/of patiëntengroepen te vertragen of zelfs te voorkomen.

Het laatste hoofdstuk plaatst de resultaten uit de voorafgaande hoofdstukken in een breder perspectief en benoemt een aantal aandachtsgebieden die in toekomstig onderzoek verdere verdieping behoeven. Dit proefschrift laat zien dat verschillende factoren een modulerende rol spelen bij de regulatie van postprandiale spiereiwitsynthese. Optimalisatie van de postprandiale spiereiwitsynthese draagt bij aan het behoud van spiermassa in zowel gezonde ouderen als patiënten, en kan de functionaliteit en mobiliteit positief beïnvloeden. 
Valorization 


\section{Valorization}

In addition to the scientific value of this dissertation described in chapters 1-7, the results of the research presented also have societal and economic value. In this addendum we put the results of this thesis in a broader perspective and highlight its potential for clinicians and policymakers in a public health setting.

Perhaps one of the most remarkable demographic developments in modern times is the progressive ageing of the population. ${ }^{1}$ Most recent predictions show that $25 \%$ of the Dutch population will be older than 65 in 2060, with nearly $40 \%$ aged 80 years and over. $^{2,3}$

Aging is accompanied by the loss of muscle mass and strength, called sarcopenia. Sarcopenia becomes evident around the age of 50, has a progressive character and is most relevant during periods of (severe) illness and immobilization. ${ }^{4}$ A clear relationship exists between the loss of muscle strength and an increase of falls, fractures, and nursing home admissions. ${ }^{5}$ Developing effective interventions to prevent or delay the onset of sarcopenia may reduce healthcare costs and improve the quality of life of older individuals. Ageing per se is not necessarily a burden, and it does not automatically decrease a person's ability to contribute to society. Older people can make valuable and important contributions to society, and may enjoy a high quality of life up to a very advanced age. The fact that people live longer is a positive sign in many ways, as life expectancy in itself is clearly associated with the general health of the population as well as the quality of the health care system. ${ }^{6}$ However, it also poses many challenges to maintain health and functional capacity in older people. Maintenance of health and functional capacity prevents social isolation, the loss of independency, and ensures that quality of life is not lowered throughout the longer lifespan. ${ }^{7}$ In this dissertation, we elucidate some of the mechanisms that may lead to sarcopenia and introduce some interventions to prevent or treat the loss of muscle mass with aging. Our focus lies on the concept of anabolic resistance of feeding and how dietary protein supplementation and physical activity may be applied to counteract the negative consequences of age-related sarcopenia. We shortly address how our findings may be relevant to define future research goals as well as how they should be implemented into intervention strategies aiming to support healthy aging.

Dietary protein intake directly stimulates muscle protein synthesis. ${ }^{8}$ However, in older individuals, the muscle protein synthetic response to protein intake is reduced, which may, at least partly, explain the age-related loss of skeletal muscle mass. ${ }^{9}$ The work presented here uses a novel stable isotope tracer methodology (Figure 10.1) to assess certain aspects of postprandial protein handling in young and older individuals following various dietary interventions. 


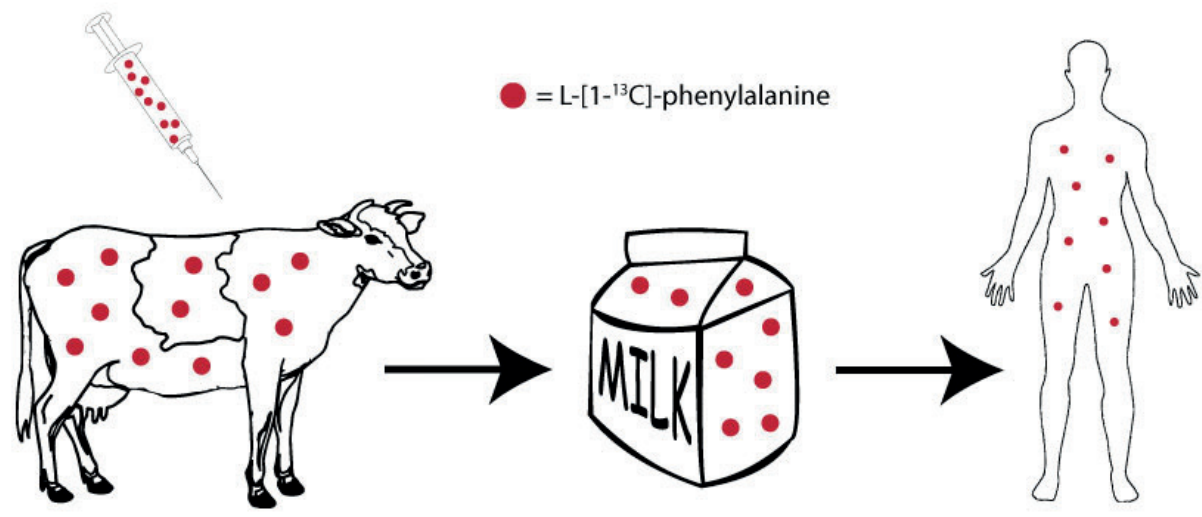

Figure 10.1 Schematic representation of the production of intrinsically labeled protein.

Using intrinsically labeled protein enables us to provide a comprehensive overview of postprandial protein handling. In chapter $\mathbf{2}$ we show that ingestion of a single meal-like amount of protein allows $\sim 55 \%$ of the protein derived amino acids to become available in the circulation, thereby improving whole-body and leg protein balance. About $20 \%$ of the dietary protein derived amino acids released in the circulation are taken up in skeletal muscle tissue following protein ingestion, thereby stimulating muscle protein synthesis rates and providing precursors for de novo muscle protein synthesis. In other words, we provide scientific evidence to show that we are what we just ate. This is both of scientific, as well industrial relevance. From a scientific point of view, reference values are created to further analyze the metabolic fate of ingested protein in healthy young men, and compare these results with other cohorts (i.e. older men, women, various patient groups, etc.). In addition, we can design and assess the efficacy of nutritional, pharmacological and exercise based interventions to optimize protein digestion, amino acid absorption and/or postprandial muscle protein synthesis.

Most of our daily protein is consumed during the three main meals, breakfast, lunch and dinner. Together, those three meals provide $50-75$ gram of protein $(0.8-1.0 \mathrm{~g} / \mathrm{kg}$ bodyweight). For a long time, it was believed that protein requirements in older people were met by these meals. However, more recent work indicates that more protein is required to allow muscle mass maintenance in the older population. ${ }^{10,11}$ The advised daily protein intake varies from 1.2 to $1.4 \mathrm{~g} / \mathrm{kg}$ bodyweight. This would mean that an average older male ( $85 \mathrm{~kg}$ ) should consume up to $100-120 \mathrm{~g}$ protein per day. In a proofof-principle study described in chapter 5 we administrated $40 \mathrm{~g}$ casein during sleep in healthy older male subjects. We show that overnight sleep represents and interesting window of opportunity to stimulate muscle protein synthesis. This will likely translate in 
the opportunity to feed dietary protein prior to sleep as a strategy to inhibit muscle protein breakdown, stimulate muscle protein synthesis and, as such, support muscle mass maintenance. Consequently, the presented data provide many new leads and targets for product development and innovations in the nutrition industry. Nutrition companies aim to improve current product formulations and develop new products or concepts to support healthy aging. Results from chapter 5 provide clear insights on the relevance of the timing of protein ingestion and the relevance of designing novel product formulations that can maximally stimulate muscle protein synthesis and, as such, assist in the various strategies to combat the loss of skeletal muscle mass with aging.

Ingestion of protein is followed by digestion and absorption of amino acids in the stomach and gut. The amino acids are transported in blood plasma, taken up in the muscle compartments, and finally incorporated into muscle tissue. Besides in vivo measurements of digestion and absorption (Chapter 2), we also assessed the role of hormonal regulation and muscle tissue perfusion on muscle mass and postprandial muscle protein synthesis. Many of the parameters that define postprandial protein handling are modulated by the postprandial rise in circulating insulin concentrations. However, the proposed stimulating role of insulin on postprandial muscle protein synthesis has been subject of intense debate. ${ }^{12,13}$ In chapter $\mathbf{3}$ we show that increased postprandial plasma insulin availability stimulates amino acid uptake over the leg, but does not further augment postprandial muscle protein synthesis rates or stimulate the postprandial deposition of protein derived amino acids into de novo muscle protein in healthy young and older men. These results are relevant from a scientific, as well as from a more clinical point of view. Scientifically, this is the first study to define the role of insulin in relation to muscle protein synthesis under physiological, postprandial conditions. The applied multi-level approach clarifies the metabolic fate of ingested protein, with or without local infusion of insulin in young and older men. We conclude that insulin is permissive rather than stimulatory in the postprandial muscle protein synthetic response. These results are also relevant from a clinical point of view since it is well known that insulin resistance commonly coexists with obesity and a sedentary lifestyle. ${ }^{14}$ To maintain muscle mass and preserve mobility with ageing and diabetes mellitus patients, home care programs should target healthy diet, stimulate physical activity and evaluate tight regulation of glucose and insulin metabolism, preferably before onset of sarcopenia becomes evident in the older population.

Plasma insulin concentrations also modulate postprandial precursor availability by stimulating blood flow in skeletal muscle tissue, thereby enhancing amino acid uptake. ${ }^{15,16}$ Adequate muscle perfusion is essential for preservation of muscle mass, as it determines the rapid postprandial delivery of nutrients (i.e. amino acids) and growth factors to the muscle, thereby stimulating muscle protein synthesis. ${ }^{17}$ An impaired 
responsiveness of the skeletal muscle microvasculature to postprandial insulin release may be attributed to impairments in muscle microvascular structure and endothelial function, which may include a decline in capillary density ${ }^{18}$ and structural changes of the endothelial wall. ${ }^{19,20}$ In chapter 4 , we conclude that aging and type 2 diabetes are accompanied with a reduced muscle mass, lower insulin sensitivity, reduced skeletal muscle capillary density, and compromised endothelial wall function. These observations indicate that both quantitative and qualitative changes in the microvasculature may contribute to the loss of skeletal muscle mass and the development of insulin resistance at a more advanced age. In particular, the endothelial glycocalyx layer appears to play an important role in the regulation of insulin sensitivity by controlling its delivery to the skeletal muscle fibers. It has recently been suggested ${ }^{21}$ that impaired tissue perfusion due to abnormality of the microvascular system (i.e. endothelial glycocalyx) is present along with other more conventional cardiovascular risk factors, including hypertension and diabetes. ${ }^{22-24}$ However, the pathology involved in vascular dysfunction in diabetes is complex and far from being understood. In Chapter 4 we extend on these observations by showing that diabetes and hyperglycemia are associated with an increased endothelial glycocalyx permeability. Loss of glycocalyx function may be a common factor in the established relationship between insulin resistance and endothelial dysfunction in patient populations. Furthermore, the results from Chapter 4 imply that such microvascular complications also play a key role in the etiology of anabolic resistance and the associated loss of skeletal muscle mass. Therefore, improving microvascular perfusion and glycocalyx integrity could represent new potential targets to prevent or decrease muscle loss and support healthy aging.

Finally, the loss of skeletal muscle mass observed during a period of bed rest or lower limb immobilization has been attributed primarily to a reduction in basal and postprandial muscle protein synthesis rates. Maintaining some level of physical activity during a period of disuse is required to attenuate the decline in muscle protein synthesis rates and prevent excessive muscle tissue loss. However, under many clinical conditions (e.g., hospitalization due to illness or injury), maintenance of physical activity is often not practical or even feasible. Therefore, surrogate interventional strategies that stimulate muscle contraction should be applied to effectively stimulate muscle protein synthesis rates and, as such, attenuate skeletal muscle loss. Neuromuscular electrical stimulation (NMES) has been proposed as an effective means to maintain some level of muscle function when habitual physical activity cannot be performed. Prolonged application of NMES has been reported to attenuate the loss of muscle mass and/or strength in patients recovering from surgery, patients suffering from severe cardiovascular complications, or patients treated in the intensive care unit. ${ }^{25-27}$ In chapter 6, we show that protein ingestion prior to sleep represents an effective interventional strategy to stimulate overnight skeletal muscle protein accretion in vivo 
in healthy, older men. The application of NMES in the evening can further augment postprandial muscle protein accretion following protein ingestion prior to sleep. The application of NMES combined with protein ingestion prior to sleep represents a feasible strategy to optimize overnight muscle protein accretion as presented in Chapter 5, and may be of great clinical benefit to attenuate muscle loss in clinically compromised individuals. Despite the necessity of studying the acute effects of NMES and dietary factors on overnight and postprandial protein handling in controlled laboratory conditions, these findings need to be confirmed in more practical and applied settings. A suitable next step to apply NMES and late-night protein ingestion in clinical conditions would be during elective, post-surgery recovery.

The research described in this dissertation determines the impact of timing of protein ingestion, muscle tissue perfusion and the role of insulin on the muscle protein synthetic response after meal ingestion. These findings can directly be applied to improve food intake and the subsequent use of amino acids for de novo muscle protein synthesis. Finally, our findings contribute to the development of new guidelines for preservation of muscle mass and prevent sarcopenia in both health and disease. It can be challenging to successfully implement such dietary intervention strategies into practice. To achieve such knowledge translation, a more interdisciplinary approach between scientists in the field of human nutrition and physiology, behavioral scientists, clinicians, and health care professionals should be pursued. The findings from 'small' experimental studies as presented in this dissertation need to be translated into larger cohort studies to evaluate the feasibility, applicability, and efficacy of changing food intake strategies to support muscle mass preservation in daily life. Besides the aging population, the results from this dissertation may be translated to other clinical conditions where progressive skeletal muscle mass loss is observed. Cancer cachexia, chronic obstructive pulmonary disease (COPD), renal insufficiency, cardiovascular disease, and diabetes commonly lead to a condition that resembles a state of accelerated ageing. As strength and muscle loss seem to be accelerated in these more clinically compromised populations, it is evident that nutritional strategies should focus both on the prevention as well as treatment of muscle loss. As individual scientists, we all work on just one piece of the puzzle. However, combining the knowledge gained from multiple studies conducted by different laboratories over the world within various fields of research will allow us to define (more) effective and sustainable dietary and physical activity intervention strategies to combat the age-related loss of skeletal muscle mass and strength and, as such, support healthy aging. 


\section{References}

1. Gwozdz W, Sousa-Poza A. Ageing, Health and Life Satisfaction of the Oldest Old: An Analysis for Germany. Soc Indic Res. 2010;97(3):397-417.

2. Beard JR, Officer A, de Carvalho IA, Sadana R, Pot AM, Michel JP, et al. The World report on ageing and health: a policy framework for healthy ageing. Lancet. 2016;387(10033):2145-54.

3. WHO. World Population Ageing 2013. Economics \& Social Affairs, 2013.

4. Wall B, Dirks M, van L. Skeletal muscle atrophy during short-term disuse: implications for age-related sarcopenia. Ageing Res Rev. 2013;12(4):898-906.

5. Marcell TJ. Sarcopenia: causes, consequences, and preventions. J Gerontol A Biol Sci Med Sci. 2003;58(10):M911-6.

6. Rechel B, Doyle Y, Grundy E, McKee M. How can health systems respond to population ageing? : World Health Organisation Geneva; 2009.

7. Statistiek CBvd. Bevolking, geslacht, leeftijd en burgerlijke staat Heerlen2010. Available from: http://www.cbs.nl/nl-NL/menu/themas/dossiers/vergrijzing/beschrijving/thema-vergrijzing.htm.

8. Volpi E, Ferrando AA, Yeckel CW, Tipton KD, Wolfe RR. Exogenous amino acids stimulate net muscle protein synthesis in the elderly. J Clin Invest. 1998;101(9):2000-7.

9. Wall BT, Gorissen SH, Pennings B, Koopman R, Groen BB, Verdijk LB, et al. Aging Is Accompanied by a Blunted Muscle Protein Synthetic Response to Protein Ingestion. PLoS One. 2015;10(11):e0140903.

10. Campbell WW, Trappe TA, Wolfe RR, Evans WJ. The recommended dietary allowance for protein may not be adequate for older people to maintain skeletal muscle. J Gerontol A Biol Sci Med Sci. 2001;56(6):M373-80.

11. Volpi E, Campbell WW, Dwyer JT, Johnson MA, Jensen GL, Morley JE, et al. Is the optimal level of protein intake for older adults greater than the recommended dietary allowance? J Gerontol A Biol Sci Med Sci. 2013;68(6):677-81.

12. Phillips SM. Insulin and muscle protein turnover in humans: stimulatory, permissive, inhibitory, or all of the above? Am J Physiol Endocrinol Metab. 2008;295(4):E731.

13. Trommelen J, Groen B, Hamer H, de Groot LC, van Loon LJ. MECHANISMS IN ENDOCRINOLOGY: Exogenous insulin does not increase muscle protein synthesis rate when administrated systemically: a systematic review. European journal of endocrinology / European Federation of Endocrine Societies. 2015.

14. Kahn SE, Hull RL, Utzschneider KM. Mechanisms linking obesity to insulin resistance and type 2 diabetes. Nature. 2006;444(7121):840-6.

15. Rasmussen BB, Fujita S, Wolfe RR, Mittendorfer B, Roy M, Rowe VL, et al. Insulin resistance of muscle protein metabolism in aging. FASEB J. 2006;20(6):768-9.

16. Timmerman K, Lee J, Fujita S, Dhanani S, Dreyer H, Fry C, et al. Pharmacological vasodilation improves insulin-stimulated muscle protein anabolism but not glucose utilization in older adults. Diabetes. 2010;59(11):2764-71.

17. Timmerman KL, Lee JL, Dreyer HC, Dhanani S, Glynn EL, Fry CS, et al. Insulin stimulates human skeletal muscle protein synthesis via an indirect mechanism involving endothelial-dependent vasodilation and mammalian target of rapamycin complex 1 signaling. J Clin Endocrinol Metab. 2010;95(8):3848-57.

18. Lillioja S, Young AA, Culter CL, Ivy JL, Abbott WG, Zawadzki JK, et al. Skeletal muscle capillary density and fiber type are possible determinants of in vivo insulin resistance in man. The Journal of clinical investigation. 1987;80(2):415-24.

19. Broekhuizen LN, Mooij HL, Kastelein JJ, Stroes ES, Vink H, Nieuwdorp M. Endothelial glycocalyx as potential diagnostic and therapeutic target in cardiovascular disease. Curr Opin Lipidol. 2009;20(1): 57-62.

20. Brandes R, Fleming I, Busse R. Endothelial aging. Cardiovascular research. 2005;66(2):286-94.

21. Villela N, Kramer-Aguiar L, Bottino D, Wiernsperger N, Bouskela E. Metabolic disturbances linked to obesity: the role of impaired tissue perfusion. Arq Bras Endocrinol Metabol. 2009 Mar;53(2):238-45.

22. De Boer MP, Meijer RI, Wijnstok NJ, Jonk AM, Houben AJ, Stehouwer CD, et al. Microvascular dysfunction: a potential mechanism in the pathogenesis of obesity-associated insulin resistance and hypertension. Microcirculation. 2012;19(1):5-18. 
23. Wilkinson SB, Tarnopolsky MA, Macdonald MJ, Macdonald JR, Armstrong D, Phillips SM. Consumption of fluid skim milk promotes greater muscle protein accretion after resistance exercise than does consumption of an isonitrogenous and isoenergetic soy-protein beverage. Am J Clin Nutr. 2007;85(4):1031-40.

24. Clark MG. Impaired microvascular perfusion: a consequence of vascular dysfunction and a potential cause of insulin resistance in muscle. Am J Physiol Endocrinol Metab. 2008;295(4):E732-50.

25. Snyder-Mackler L, Delitto A, Stralka SW, Bailey SL. Use of electrical stimulation to enhance recovery of quadriceps femoris muscle force production in patients following anterior cruciate ligament reconstruction. Phys Ther. 1994;74(10):901-7.

26. Banerjee P, Caulfield B, Crowe L, Clark A. Prolonged electrical muscle stimulation exercise improves strength, peak VO2, and exercise capacity in patients with stable chronic heart failure. J Card Fail. 2009;15(4):319-26.

27. Gerovasili V, Stefanidis K, Vitzilaios K, Karatzanos E, Politis P, Koroneos A, et al. Electrical muscle stimulation preserves the muscle mass of critically ill patients: a randomized study. Crit Care. 2009;13(5):R161. 
Dankwoord 


\section{Dankwoord}

Het meest gelezen hoofdstuk van een proefschrift, en terecht.

De realisatie van dit project was alleen mogelijk omdat ik het geluk en genoegen had met plezierige en gemotiveerde mensen te mogen samenwerken. Ik zou me schamen als ik iemand nu pas voor het eerst zou gaan bedanken voor zijn of haar inspanningen. Ik hoop dan ook dat alle betrokkenen weten dat ik de hulp erg gewaardeerd heb. Een aantal mensen wil ik toch noemen.

Allereerst de proefpersonen en vrijwilligers die deelnamen in de klinische studies.

Ook gaat mijn dank uit naar de beoordelingscommissie en de overige leden van de promotiecommissie.

In het bijzonder wil ik Luc bedanken. Tot hier was ik nooit gekomen als jij niet in 2006 het vertrouwen had uitgesproken dat toekomstige pillenschrijvers ook onderzoek kunnen verrichten. Het geduld en persoonlijke wijze van coaching heb ik erg gewaardeerd en hebben mij niet alleen binnen het onderzoek, maar ook daarbuiten veel over mijzelf en de wereld om mij heen geleerd. Die kennis neem ik mee en hoop ik ook op andere vlakken te kunnen blijven benutten.

Henrike en Astrid: jullie steun en enthousiasme was er altijd en motiveerde mij telkens weer om kritisch en met een relativerende blik naar ons werk te kijken. Ik denk dat we een mooi resultaat hebben afgeleverd en met gepaste trots op de afgelopen jaren terug mogen kijken.

Alle collega's van de M3 groep, in het bijzonder de mensen die mij op weg geholpen hebben (Peter, Tim, Jan-Willem en Bart), dank voor het spreekwoordelijke 'warme nest' waarin ik 4 jaar mocht werken. Ik denk dat de resultaten die geboekt zijn alleen mogelijk waren omdat er een team was waarin alle neuzen spreekwoordelijk dezelfde kant op stonden en iedereen verantwoordelijkheid nam. Het analyseren van duizenden samples of pas genoegen nemen met resultaten die aan (of boven) de grens van het haalbare liggen zijn hier goede voorbeelden van. Vier jaar in zo'n groep mogen werken is een bijzondere en goede leerschool geweest. Het heeft mij veel meer gebracht dan een paar artikelen en een titel. Ook de collega's die ik later heb leren kennen, in het bijzonder Imre, Marlou, Stefan, Rachel en Evelien: jullie vormen allemaal (en ieder op zijn of haar eigen manier) voorbeelden hoe je kunt groeien als onderzoeker, maar ook als mens. Dank jullie wel hiervoor.

Bert, Eric, Job, Jos en Thieu: dank voor jullie begrip en (onbewust) sturende opmerkingen. Wat fijn om in deze periode te hebben mogen vertrouwen op zoveel 
goedheid en flexibiliteit. De waarde van vriendschap is voor mij nog duidelijker geworden en ik hoop hier nog lang van te mogen blijven genieten.

Dichter bij huis in letterlijke en figuurlijke zin wil ik mijn ouders, zus, broer en schoonzus bedanken voor een warm thuis van waaruit kennelijk de juiste karaktereigenschappen zijn voortgekomen om tot hier te geraken. Een ouderlijk voorbeeld, gemengd met een gezonde dosis menselijk inzicht en levenservaring brengen een promovendus verder dan een idee en een tekst. Ik hoop dat we daar samen nog lang en in goede gezondheid van mogen blijven genieten.

En tenslotte natuurlijk Marlies: zonder jou was ik zeker niet tot dit hoofdstuk gekomen. Het wordt gezegd dat een promotie een prestatie van twee personen is. Het klopt. Meer nog dan iedereen ben ik jou dankbaar voor je steun en toeverlaat. Je relativeerde, was kritisch en wist met humor altijd de slag te winnen. ledere dag besef ik weer dat die man uit Pangkalan Bun gelijk had: We are a good couple. 
Curriculum vitae 


\section{Curriculum vitae}

Bart Groen was born January 23, 1982 in Heerlen. He completed secondary school at the Bernardinus college in Heerlen in 2000. Bart obtained his master degree in Human Movement Sciences in 2006 under supervision of Dr. Ralph Manders, investigating the role of exercise training in type 2 diabetic patients using continuous glucose monitoring. Parallel on this, he obtained his Bachelor degree in Medicine in 2007, followed by his Master's degree in 2009. Part of his education was completed abroad with a clinical internship in traumatology and orthopedic surgery in Nahariya (Israel). After finishing his medicine study, he started his PhD project under supervision of Prof. Dr. Luc van Loon. In 2011 he visited the laboratory of Prof. Blake Rasmussen at the University of Texas Medical Branch to undertake further research training, specifically setting up an AV-balance experiment with stable isotope tracers. During his PhD, Bart successfully supervised several Bachelor's and Master's student. He was nominated for best tutor of the year at the medicine department in 2014. After finishing his research projects at the Human Movement department, he worked as a resident at the department of cardiology and internal medicine at the Zuyderland Hospital in 2015. In 2016 he commenced his General Practitioner trainee ship at Maastricht University which will be finished in 2018. 
List of publications 


\section{List of publications}

Koopman R, Gleeson BG, Gijsen AP, Groen BB, Senden JM, Rennie MJ, et al. Postexercise protein synthesis rates are only marginally higher in type I compared with type II muscle fibres following resistance-type exercise. Eur J Appl Physiol. 2011;111(8):18718.

Groen BB, Res PT, Pennings B, Hertle E, Senden JM, Saris WH, et al. Intragastric protein administration stimulates overnight muscle protein synthesis in elderly men. Am J Physiol Endocrinol Metab. 2012;302(1):E52-60.

Burd NA, Groen BB, Beelen M, Senden JM, Gijsen AP, van Loon LJ. The reliability of using the single-biopsy approach to assess basal muscle protein synthesis rates in vivo in humans. Metabolism. 2012;61(7):931-6.

Burd NA, Pennings B, Groen BB, Gijsen AP, Senden JM, van Loon LJ. The single biopsy approach is reliable for the measurement of muscle protein synthesis rates in vivo in older men. J Appl Physiol. 2012;113(6):896-902.

Pennings B, Groen BB, de Lange A, Gijsen AP, Zorenc AH, Senden JM, et al. Amino acid absorption and subsequent muscle protein accretion following graded intakes of whey protein in elderly men. Am J Physiol Endocrinol Metab. 2012;302(8):E992-9.

Res PT, Groen BB, Pennings B, Beelen M, Wallis GA, Gijsen AP, et al. Protein ingestion prior to sleep improves post-exercise overnight recovery. Med Sci Sports Exerc. 2012.

Wall BT, Hamer HM, de Lange A, Kiskini A, Groen BB, Senden JM, et al. Leucine coingestion improves post-prandial muscle protein accretion in elderly men. Clin Nutr. 2013;32(3):412-9.

Hamer HM, Wall BT, Kiskini A, de Lange A, Groen BB, Bakker JA, et al. Carbohydrate coingestion with protein does not further augment post-prandial muscle protein accretion in older men. Nutr Metab (Lond). 2013;10(1):15.

Kiskini A, Hamer HM, Wall BT, Groen BB, de Lange A, Bakker JA, et al. The muscle protein synthetic response to the combined ingestion of protein and carbohydrate is not impaired in healthy older men. Age (Dordr). 2013;35(6):2389-98.

Nilwik R, Snijders T, Leenders M, Groen BB, van Kranenburg J, Verdijk LB, et al. The decline in skeletal muscle mass with aging is mainly attributed to a reduction in type II muscle fiber size. Exp Gerontol. 2013;48(5):492-8. 
Pennings B, Groen BB, van Dijk JW, de Lange A, Kiskini A, Kuklinski M, et al. Minced beef is more rapidly digested and absorbed than beef steak, resulting in greater postprandial protein retention in older men. Am J Clin Nutr. 2013;98(1):121-8.

Gorissen SH, Burd NA, Hamer HM, Gijsen AP, Groen BB, van Loon L. Carbohydrate coingestion delays dietary protein digestion and absorption but does not modulate postprandial muscle protein accretion. J Clin Endocrinol Metab. 2014;99(6):2250-8.

Groen BB, Hamer HM, Snijders T, van Kranenburg J, Frijns D, Vink H, et al. Skeletal muscle capillary density and microvascular function are compromised with aging and type 2 diabetes. J Appl Physiol (1985). 2014;116(8):998-1005.

Snijders T, Verdijk LB, McKay BR, Smeets JS, van Kranenburg J, Groen BB, et al. Acute dietary protein intake restriction is associated with changes in myostatin expression after a single bout of resistance exercise in healthy young men. J Nutr. 2014;144(2):137-45.

Groen BB, Horstman AM, Hamer HM, de Haan M, van Kranenburg J, Bierau J, et al. Post-Prandial Protein Handling: You Are What You Just Ate. PLoS One. 2015;10(11):e0141582.

Trommelen J, Groen BB, Hamer HM, de Groot LC, van Loon LJ. MECHANISMS IN ENDOCRINOLOGY: Exogenous insulin does not increase muscle protein synthesis rate when administered systemically: a systematic review. Eur J Endocrinol. 2015;173(1):R25-34

Wall BT, Gorissen SH, Pennings B, Koopman R, Groen BB, Verdijk LB, et al. Aging Is Accompanied by a Blunted Muscle Protein Synthetic Response to Protein Ingestion. PLoS One. 2015;10(11):e0140903.

Groen BB, Horstman AM, Hamer HM, De Haan M, van Kranenburg J, Bierau J, et al. Increasing insulin availability does not augment post-prandial muscle protein synthesis rates in healthy young and older men. J Clin Endocrinol Metab. 2016. 
